\title{
CONSTRUINDO A CULPA E EVITANDO A PREVENÇÃO: CAMINHOS DA INVESTIGAÇÃO DE ACIDENTES DO TRABALHO EM EMPRESAS DE MUNICÍPIO DE PORTE MÉDIO. BOTUCATU, SÃO PAULO, 1997.
}

\section{ILDEBERTO MUNIZ DE ALMEIDA}

Tese de Doutorado apresentada ao

Departamento de Saúde Ambiental da

Faculdade de Saúde Pública - USP - para

obtenção do Grau de Doutor.

Área de concentração:

Saúde Ambiental

Orientadora: Prof ${ }^{\mathrm{a}}$ Titular

Frida Marina Fischer

São Paulo 


\section{CONSTRUINDO A CULPA E EVITANDO A PREVENÇÃO: CAMINHOS DA INVESTIGAÇÃO DE ACIDENTES DO TRABALHO EM EMPRESAS DE MUNICÍPIO DE PORTE MÉDIO. BOTUCATU, SÃO PAULO, 1997.}

\section{ILDEBERTO MUNIZ DE ALMEIDA}

Tese de Doutorado apresentada ao

Departamento de Saúde Ambiental da

Faculdade de Saúde Pública - USP - para

obtenção do Grau de Doutor.

Área de concentração:

Saúde Ambiental

Orientadora: Prof ${ }^{\mathrm{a}}$ Titular

Frida Marina Fischer

São Paulo 
Autorizo, exclusivamente para fins acadêmicos e científicos, a reprodução total ou parcial desta tese, por processos fotocopiadores.

Assinatura:

Data: 


\section{DEDICATÓRIA}

A ANA MARIA MARCHI e ISADORA MARCHI DE ALMEIDA, companheira e filha, pelo carinho que sempre me dedicaram e, especialmente, pela atenção e paciência que souberam ter para comigo durante os anos de preparo desta tese. 


\section{AGRADECIMENTOS}

À Prof ${ }^{a}$. Titular FRIDA MARINA FISCHER, incentivadora de primeira hora, que, além de interlocutora constante, soube revelar-se amiga e conselheira profissional. Sem cercear-me em nenhum momento, mostrou-se firme quando necessário e ajudou-me a reconhecer aspectos essenciais a serem contemplados neste estudo. Sem sua ajuda, ele dificilmente teria sido realizado.

À Prof ${ }^{\mathrm{a}}$. Doutora MARIA CECÍLIA PEREIRA BINDER, amiga, colega de trabalho e ponto de apoio sempre disponível. Sua contribuição esteve presente na escolha deste tema, disponibilizando secretário particular para digitação de banco de dados e em outros momentos ao longo dos anos de realização deste estudo.

Ao Prof. Dr. LAERTE SZNELWAR e à Prof ${ }^{a}$ Dr $^{a}$ LENY SATO, membros da banca do Exame de Qualificação, pelos comentários, incentivo e sugestões apresentados, com vistas ao aprimoramento do projeto original.

À DIRETORIA REGIONAL DE SAÚDE DE BOTUCATU, DIR XI, em especial à Sra. TEREZINHA BARRIQUELO, chefe da Diretoria de Vigilância Sanitária, pela ajuda oferecida, em especial na fase de coleta de dados deste estudo.

À SUBDELEGACIA REGIONAL DO MINISTÉRIO DO TRABALHO E EMPREGO DE BAURU, particularmente ao Sr. Sub-delegado Eng ${ }^{\circ}$ SÉRGIO BRANCO, pela ajuda oferecida, em especial na fase de coleta de dados deste estudo. Aos funcionários e chefia do DEPARTAMENTO DE SAÚDE PÚBLICA DA FACULDADE DE MEDICINA DA UNESP, em especial a MARCOS BALLESTERO e LUCIANA ELENA NASCIMENTO, pelo apoio oferecido durante todo o período de realização deste trabalho, especialmente nas etapas de entendimentos institucionais e de coleta de dados, e no apoio face às inúmeras dificuldades enfrentadas na convivência com os computadores.

A TERESINHA ARAGON, pela inestimável ajuda no trabalho de revisão gramatical do texto. 


\section{RESUMO}

Almeida IM. Construindo a culpa e evitando a prevenção: caminhos da investigação de acidentes do trabalho em empresas de município de médio porte. Botucatu, São Paulo, 1997. São Paulo, 2000. [Tese de Doutorado Faculdade de Saúde Pública da USP].

Objetivos. Analisar investigações de acidentes e materiais didáticos e educativos, explorando aspectos da construção das análises e de atribuição de culpa. Métodos. Registros de investigações e materiais didáticos de empresas de Botucatu-SP, em 1997, obtidos de instituições e empresas, foram analisados, identificando-se fatores causais, recomendações e referências a comportamentos faltosos ou características da vítima. Árvores de causas foram checadas quanto a cuidados de linguagem, desenhos, interrupções da investigação, tipos de relações entre fatos e exploração para prevenção. Materiais educativos foram analisados, identificando-se concepções de acidente, orientações para investigações e recomendações. Bancos de dados foram formados e gerenciados com EPIinfo. Resultados. Foram analisadas 203 investigações. A média de "causas" por AT foi 1,68 e a de recomendações foi 1,4 por AT, com predomínio de referências a comportamentos ou características da vítima. A maioria das análises baseava-se em formulário obrigatório. Todas as árvores analisadas mostravam desrespeito flagrante a regras e princípios do método. Materiais didáticos veiculavam mesma concepção de acidente das investigações, método de análise centrado em comportamentos faltosos do operador, estímulo ao medo de lesões e recomendações para obediência a regras e uso de equipamentos de proteção. Conclusão. As investigações adotam concepção de acidente baseada na identificação de situações de desrespeito a regras idealizadas, atribuem culpa ao acidentado e não subsidiam a gestão de riscos nas empresas. A atribuição de culpa ocorre independentemente da natureza e/ou tipo de perigo presente nos acidentes. Tentativas de uso do método de árvore de causas mostraram distorções, revelando insuficiência no seu domínio. A construção da culpa foi reforçada por materiais didáticos e educativos. 
Descritores: Acidentes do trabalho, investigações de acidentes, vigilância de acidentes. 


\section{SUMMARY}

Almeida IM. Building blame and avoiding prevention: ways of investigating accidents in companies in a medium-size city. Botucatu, São Paulo, 1997. São Paulo, 2001. [Tese de Doutorado - Faculdade de Saúde Pública da USP].

Objectives: To analyze accident investigations and teaching and educational materials exploring aspects of analysis construction and blame attribution. Methods: Investigation reports and educational materials of companies in Botucatu, SP, in 1997, obtained from institutions and companies were analyzed and causal factors, recommendations and references to faulty behavior or victim characteristics were identified. Causal tree were checked in regard to language, design, investigation interruptions, types of relations between facts and exploration for prevention. Educational materials were analyzed identifying the conception of accident, orientation for investigations and recommendation. Data banks were formed and managed by EPIinfo. Results: 203 investigations with an average of 1,68 causes and 1,4 recommendations were analyzed and revealed that references to victim's behavior or characteristics prevailed. Most analyses were based on an obligatory form. All analyzed trees showed evident disrespect to rules and methodological principles. The educational and teaching materials convey the same accident concept as the investigations, the analyses method centered in the faulty behavior of the operator, stimulus of fear to injury and recommendation for obedience to rules and use of protection equipment. Conclusion: The investigations studied use an accident concept based on the identification of situations of disrespect to idealized rules, blame the injured subjects, and do not support the risk management in the companies. The blame bias occurs independently of the nature or kind of danger involved in the accidents. The attempts to use the causal tree method revealed distortions due to insufficient command. Educational materials strengthened the construction of blame. 


\section{ESTRELA DA TERRA}

\section{(Dori Caymmi / Paulo César Pinheiro)}

Por mais que haja dor e agonia

Por mais que haja treva sombria

Existe uma luz que é uma guia

Fincada no azul da amplidão

É o claro da estrela do dia

Sobre a terra da promissão

Por mais que a canção faça alarde

Por mais que o cristão se acovarde

Existe uma chama que arde

E que não se apaga mais não

É o brilho da estrela da tarde

Na boina do meu capitão

E a gente

Rebenta do peito a corrente

Com a ponta da lâmina ardente

Da estrela da palma da mão

Por mais que a paixão não se afoite

Por mais que a minha alma se amoite

Existe um clarão que é um açoite

Mais forte e maior que a paixão

É o raio da estrela da noite

Cravada no meu coração
E a gente

Já prepara o chão pra semente

Pra vinda da estrela cadente

Que vai florescer o sertão

Igual toda lenda se encerra

Virá um cavaleiro de guerra

Cantando do alto da serra

Montado no seu alazão

Trazendo a estrela da terra

Sinal de uma nova estação 


\section{Índice}

1 INTRODUÇÃO

1.1 Trajetória da noção de acidentes do trabalho e de sua 2 investigação

$1.2 \mathrm{O}$ acidente de trabalho e suas causas: as noções de fatalidade e de seqüência linear de eventos

1.3 Multicausalidade, rede de múltiplas causas em interação, erro humano, aprendizado organizacional e compromisso cognitivo

1.4 A concepção predominante no Brasil

1.5 Tipologia de acidentes e acidente normal

1.6 Investigações de acidentes do trabalho: importância, limites e questionamentos

1.7 As noções de culpa e responsabilidade, na legislação de responsabilidade civil e previdenciária

1.8 Atribuição de causa e responsabilidade na psicologia

1.9 Atribuição de causa e culpa na literatura de investigações de acidentes

1.10 Influências das concepções de causa, culpa e responsabilidade na investigação de acidentes do trabalho no Brasil

1.11 Algumas dificuldades apontadas na investigação de acidentes

1.12 Consequiências das atribuições de causa e de culpa: a inibição da prevenção

1.13 Estimulando o medo e atribuindo culpa: a prevenção de acidentes em materiais didático-educativos usados nas empresas

2 OBJETIVOS

3 MATERIAL E MÉTODOS 72

3.1 Material 
3.2.1 Obtenção da relação de empresas possuidoras de CIPA, registradas no Ministério do Trabalho, no ano de 1997

3.2.2 Obtenção da relação de empresas que tiveram acidente do trabalho registrado junto à Previdência Social, no ano de 1997

3.2.3 Identificação de empresas possuidoras de CIPA que tiveram acidente registrado no ano de 1997

3.2.4 Obtenção dos materiais junto às empresas

3.2.5 Instrumentos de coleta de material

3.2.6 Transcrição e classificação de informações

3.2.6.1 Relativas aos registros de investigações de acidentes

3.2.6.2 Relativas aos materiais didático-instrucionais

3.2.7 Criação de bancos de dados e emissão de relatórios para análise

\section{RESULTADOS E DISCUSSÃO}

4.1 O universo de empresas estudadas

4.2 As práticas de investigação de acidentes adotadas nas empresas

4.3 Análise das árvores de causas elaboradas por 4 empresas de Botucatu

4.3.1 O uso das categorias de análise do método

100

4.3.2 Cuidados de linguagem, definição e denominação dos fatores de acidente

104

4.3.3 Checagem da montagem da árvore

4.3.4 Quando pára a investigação conduzida na empresa?

4.3.5 A exploração das árvores: como os esquemas foram usados na prevenção? 
4.3.6 Falhas na investigação de acidentes e nas práticas de segurança

4.3.7 Pequeno comentário acerca de medidas de prevenção propostas na empresa $\mathrm{D}$

4.3.8 Distorções na implantação do método ADC

145

4.3.9 Tipos de acidentes analisados com método de árvore de causas e indicação de uso desse método

4.4 Concepções de acidentes do trabalho e de sua investigação em materiais didático-educativos usados nas empresas

4.4.1 Causas e investigações de acidentes em materiais didático-educativos usados na formação de membros de CIPA das empresas estudadas

4.4.2 Materiais dedicados à prevenção

4.4.3 Frases e cartazes de segurança: estímulo ao medo e atribuição de culpa

4.5 Investigações de acidentes: fator de viabilização de condições perigosas?

4.6 As práticas de prevenção de acidentes do trabalho, em empresas de Botucatu

4.7 Para onde vai a investigação de acidentes do trabalho?

186

5 CONCLUSÕES

6 REFERÊNCIAS

202

ANEXOS

A-1

Anexo 1 - Ficha de análise de acidentes da Norma Regulamentadora $\mathrm{n}^{\circ} 5$

Anexo 2 - Ficha de acidente do trabalho da Norma Regulamentadora $\mathrm{n}^{\mathrm{o}} 18$

Anexo 3 - Ficha de entrada de dados

Anexo 4 - Ficha de análise de árvore de causas

A-13 
Anexo 5 - Ficha de registro de informações referentes a materiais A-15 didático-instrucionais

Anexo 6 - Tabelas detalhadas

A -16 
Autorizo, exclusivamente para fins acadêmicos e científicos, a reprodução total ou parcial desta tese, por processos fotocopiadores.

Assinatura:

Data: 


\section{DEDICATÓRIA}

A ANA MARIA MARCHI e ISADORA MARCHI DE ALMEIDA, companheira e filha, pelo carinho que sempre me dedicaram e, especialmente, pela atenção e paciência que souberam ter para comigo durante os anos de preparo desta tese. 


\section{AGRADECIMENTOS}

À Prof ${ }^{a}$. Titular FRIDA MARINA FISCHER, incentivadora de primeira hora, que, além de interlocutora constante, soube revelar-se amiga e conselheira profissional. Sem cercear-me em nenhum momento, mostrou-se firme quando necessário e ajudou-me a reconhecer aspectos essenciais a serem contemplados neste estudo. Sem sua ajuda, ele dificilmente teria sido realizado.

À Prof ${ }^{\mathrm{a}}$. Doutora MARIA CECÍLIA PEREIRA BINDER, amiga, colega de trabalho e ponto de apoio sempre disponível. Sua contribuição esteve presente na escolha deste tema, disponibilizando secretário particular para digitação de banco de dados e em outros momentos ao longo dos anos de realização deste estudo.

Ao Prof. Dr. LAERTE SZNELWAR e à Prof ${ }^{a}$ Dr $^{a}$ LENY SATO, membros da banca do Exame de Qualificação, pelos comentários, incentivo e sugestões apresentados, com vistas ao aprimoramento do projeto original.

À DIRETORIA REGIONAL DE SAÚDE DE BOTUCATU, DIR XI, em especial à Sra. TEREZINHA BARRIQUELO, chefe da Diretoria de Vigilância Sanitária, pela ajuda oferecida, em especial na fase de coleta de dados deste estudo.

À SUBDELEGACIA REGIONAL DO MINISTÉRIO DO TRABALHO E EMPREGO DE BAURU, particularmente ao Sr. Sub-delegado Eng ${ }^{\circ}$ SÉRGIO BRANCO, pela ajuda oferecida, em especial na fase de coleta de dados deste estudo. Aos funcionários e chefia do DEPARTAMENTO DE SAÚDE PÚBLICA DA FACULDADE DE MEDICINA DA UNESP, em especial a MARCOS BALLESTERO e LUCIANA ELENA NASCIMENTO, pelo apoio oferecido durante todo o período de realização deste trabalho, especialmente nas etapas de entendimentos institucionais e de coleta de dados, e no apoio face às inúmeras dificuldades enfrentadas na convivência com os computadores.

A TERESINHA ARAGON, pela inestimável ajuda no trabalho de revisão gramatical do texto. 


\section{RESUMO}

Almeida IM. Construindo a culpa e evitando a prevenção: caminhos da investigação de acidentes do trabalho em empresas de município de médio porte. Botucatu, São Paulo, 1997. São Paulo, 2000. [Tese de Doutorado Faculdade de Saúde Pública da USP].

Objetivos. Analisar investigações de acidentes e materiais didáticos e educativos, explorando aspectos da construção das análises e de atribuição de culpa. Métodos. Registros de investigações e materiais didáticos de empresas de Botucatu-SP, em 1997, obtidos de instituições e empresas, foram analisados, identificando-se fatores causais, recomendações e referências a comportamentos faltosos ou características da vítima. Árvores de causas foram checadas quanto a cuidados de linguagem, desenhos, interrupções da investigação, tipos de relações entre fatos e exploração para prevenção. Materiais educativos foram analisados, identificando-se concepções de acidente, orientações para investigações e recomendações. Bancos de dados foram formados e gerenciados com EPIinfo. Resultados. Foram analisadas 203 investigações. A média de "causas" por AT foi 1,68 e a de recomendações foi 1,4 por AT, com predomínio de referências a comportamentos ou características da vítima. A maioria das análises baseava-se em formulário obrigatório. Todas as árvores analisadas mostravam desrespeito flagrante a regras e princípios do método. Materiais didáticos veiculavam mesma concepção de acidente das investigações, método de análise centrado em comportamentos faltosos do operador, estímulo ao medo de lesões e recomendações para obediência a regras e uso de equipamentos de proteção. Conclusão. As investigações adotam concepção de acidente baseada na identificação de situações de desrespeito a regras idealizadas, atribuem culpa ao acidentado e não subsidiam a gestão de riscos nas empresas. A atribuição de culpa ocorre independentemente da natureza e/ou tipo de perigo presente nos acidentes. Tentativas de uso do método de árvore de causas mostraram distorções, revelando insuficiência no seu domínio. A construção da culpa foi reforçada por materiais didáticos e educativos. 
Descritores: Acidentes do trabalho, investigações de acidentes, vigilância de acidentes. 


\section{SUMMARY}

Almeida IM. Building blame and avoiding prevention: ways of investigating accidents in companies in a medium-size city. Botucatu, São Paulo, 1997. São Paulo, 2001. [Tese de Doutorado - Faculdade de Saúde Pública da USP].

Objectives: To analyze accident investigations and teaching and educational materials exploring aspects of analysis construction and blame attribution. Methods: Investigation reports and educational materials of companies in Botucatu, SP, in 1997, obtained from institutions and companies were analyzed and causal factors, recommendations and references to faulty behavior or victim characteristics were identified. Causal tree were checked in regard to language, design, investigation interruptions, types of relations between facts and exploration for prevention. Educational materials were analyzed identifying the conception of accident, orientation for investigations and recommendation. Data banks were formed and managed by EPIinfo. Results: 203 investigations with an average of 1,68 causes and 1,4 recommendations were analyzed and revealed that references to victim's behavior or characteristics prevailed. Most analyses were based on an obligatory form. All analyzed trees showed evident disrespect to rules and methodological principles. The educational and teaching materials convey the same accident concept as the investigations, the analyses method centered in the faulty behavior of the operator, stimulus of fear to injury and recommendation for obedience to rules and use of protection equipment. Conclusion: The investigations studied use an accident concept based on the identification of situations of disrespect to idealized rules, blame the injured subjects, and do not support the risk management in the companies. The blame bias occurs independently of the nature or kind of danger involved in the accidents. The attempts to use the causal tree method revealed distortions due to insufficient command. Educational materials strengthened the construction of blame. 


\section{ESTRELA DA TERRA}

\section{(Dori Caymmi / Paulo César Pinheiro)}

Por mais que haja dor e agonia

Por mais que haja treva sombria

Existe uma luz que é uma guia

Fincada no azul da amplidão

É o claro da estrela do dia

Sobre a terra da promissão

Por mais que a canção faça alarde

Por mais que o cristão se acovarde

Existe uma chama que arde

E que não se apaga mais não

É o brilho da estrela da tarde

Na boina do meu capitão

E a gente

Rebenta do peito a corrente

Com a ponta da lâmina ardente

Da estrela da palma da mão

Por mais que a paixão não se afoite

Por mais que a minha alma se amoite

Existe um clarão que é um açoite

Mais forte e maior que a paixão

É o raio da estrela da noite

Cravada no meu coração
E a gente

Já prepara o chão pra semente

Pra vinda da estrela cadente

Que vai florescer o sertão

Igual toda lenda se encerra

Virá um cavaleiro de guerra

Cantando do alto da serra

Montado no seu alazão

Trazendo a estrela da terra

Sinal de uma nova estação 


\section{Índice}

1 INTRODUÇÃO

1.1 Trajetória da noção de acidentes do trabalho e de sua 2 investigação

$1.2 \mathrm{O}$ acidente de trabalho e suas causas: as noções de fatalidade e de seqüência linear de eventos

1.3 Multicausalidade, rede de múltiplas causas em interação, erro humano, aprendizado organizacional e compromisso cognitivo

1.4 A concepção predominante no Brasil

1.5 Tipologia de acidentes e acidente normal

1.6 Investigações de acidentes do trabalho: importância, limites e questionamentos

1.7 As noções de culpa e responsabilidade, na legislação de responsabilidade civil e previdenciária

1.8 Atribuição de causa e responsabilidade na psicologia

1.9 Atribuição de causa e culpa na literatura de investigações de acidentes

1.10 Influências das concepções de causa, culpa e responsabilidade na investigação de acidentes do trabalho no Brasil

1.11 Algumas dificuldades apontadas na investigação de acidentes

1.12 Consequiências das atribuições de causa e de culpa: a inibição da prevenção

1.13 Estimulando o medo e atribuindo culpa: a prevenção de acidentes em materiais didático-educativos usados nas empresas

2 OBJETIVOS

3 MATERIAL E MÉTODOS 72

3.1 Material 
3.2.1 Obtenção da relação de empresas possuidoras de CIPA, registradas no Ministério do Trabalho, no ano de 1997

3.2.2 Obtenção da relação de empresas que tiveram acidente do trabalho registrado junto à Previdência Social, no ano de 1997

3.2.3 Identificação de empresas possuidoras de CIPA que tiveram acidente registrado no ano de 1997

3.2.4 Obtenção dos materiais junto às empresas

3.2.5 Instrumentos de coleta de material

3.2.6 Transcrição e classificação de informações

3.2.6.1 Relativas aos registros de investigações de acidentes

3.2.6.2 Relativas aos materiais didático-instrucionais

3.2.7 Criação de bancos de dados e emissão de relatórios para análise

\section{RESULTADOS E DISCUSSÃO}

4.1 O universo de empresas estudadas

4.2 As práticas de investigação de acidentes adotadas nas empresas

4.3 Análise das árvores de causas elaboradas por 4 empresas de Botucatu

4.3.1 O uso das categorias de análise do método

100

4.3.2 Cuidados de linguagem, definição e denominação dos fatores de acidente

104

4.3.3 Checagem da montagem da árvore

4.3.4 Quando pára a investigação conduzida na empresa?

4.3.5 A exploração das árvores: como os esquemas foram usados na prevenção? 
4.3.6 Falhas na investigação de acidentes e nas práticas de segurança

4.3.7 Pequeno comentário acerca de medidas de prevenção propostas na empresa $\mathrm{D}$

4.3.8 Distorções na implantação do método ADC

145

4.3.9 Tipos de acidentes analisados com método de árvore de causas e indicação de uso desse método

4.4 Concepções de acidentes do trabalho e de sua investigação em materiais didático-educativos usados nas empresas

4.4.1 Causas e investigações de acidentes em materiais didático-educativos usados na formação de membros de CIPA das empresas estudadas

4.4.2 Materiais dedicados à prevenção

4.4.3 Frases e cartazes de segurança: estímulo ao medo e atribuição de culpa

4.5 Investigações de acidentes: fator de viabilização de condições perigosas?

4.6 As práticas de prevenção de acidentes do trabalho, em empresas de Botucatu

4.7 Para onde vai a investigação de acidentes do trabalho?

186

5 CONCLUSÕES

6 REFERÊNCIAS

202

ANEXOS

A-1

Anexo 1 - Ficha de análise de acidentes da Norma Regulamentadora $\mathrm{n}^{\circ} 5$

Anexo 2 - Ficha de acidente do trabalho da Norma Regulamentadora $\mathrm{n}^{\mathrm{o}} 18$

Anexo 3 - Ficha de entrada de dados

Anexo 4 - Ficha de análise de árvore de causas

A-13 
Anexo 5 - Ficha de registro de informações referentes a materiais A-15 didático-instrucionais

Anexo 6 - Tabelas detalhadas

A -16 


\section{INTRODUÇÃO}

\subsection{Trajetória da noção de acidentes do trabalho e de sua investigação}

Este estudo trata de investigações de acidentes do trabalho (AT). Inicialmente, apresenta-se definição de acidente e/ou acidente do trabalho e, em seguida, discorrese acerca da trajetória da concepção de acidente do trabalho na literatura. A partir daí, discute-se a investigação propriamente dita desses eventos, procurando-se identificar possíveis relações entre as concepções de acidente adotadas, as práticas de análise sugeridas e os resultados nelas obtidos. Dessa forma, a elaboração do texto aparece permeada por uma espécie de questão explicitada pelo contraste entre a abordagem de acidentes na literatura e nas práticas de investigações.

Introduzindo paralelo com tema da culinária, que será retomado em outros momentos do texto, pode-se dizer que o sabor de fundo desta "tese-prato" é dado pela questão: Como as práticas de investigação de acidentes desenvolvidas nas empresas estudadas incorporam aspectos da abordagem dos acidentes do trabalho na literatura dedicada a esses eventos e, em particular, à sua investigação?

\section{$1.2 \mathrm{O}$ acidente e suas causas: as noções de fatalidade e de seqüência linear de eventos}

De acordo com conhecido dicionário da língua portuguesa, a palavra acidente é substantivo masculino que designa "acontecimento casual, fortuito, imprevisto". Ainda segundo o mesmo autor, outro sentido para o termo acidente é o de "acontecimento infeliz, casual ou não, e de que resulta ferimento, dano, estrago, prejuízo, avaria, ruína, etc.; desastre” (Ferreira 1995).

Referências a "origens de causas remotas e desconhecidas", "eventos não planejados, não previstos", "falta de intenção" aparecem na literatura técnica relativa a acidentes (Hale e Hale 1972; Brown 1992). Também no imaginário de trabalhadores aparecem referências a acidentes como produtos da falta de sorte, ou azar, ou, ainda, descuidos da própria vítima (Kouabenan 1999; Almeida e col. 2000). 
Surry (1971) cita definição operacional de acidente dada por Suchman: “[...] classe de eventos que envolve um baixo nível de expectativa, evitabilidade e intencionalidade". Além disso, os acidentes apresentariam "baixos níveis (ou graus)" de aviso, duração, negligência e erro de julgamento ("misjudgement”). Questionando quem julga essas estimativas de "grau", o próprio Surry (1971) aponta a necessidade de cuidados na utilização dessas noções.

Em 1972, Hale e Hale destacaram a existência de diferenças no conceito de acidente do trabalho adotado em diversos estudos. Segundo os autores, esse fato decorre, entre outros fatores, de influência da fonte de informações e da classificação de gravidade de lesões usadas nos estudos.

Brown (1992) aponta as possibilidades de interferência dos interesses do grupo profissional que conduz a investigação na definição de acidente. Assim, para psicólogos, o acidente pode ser definido como "falha para agir corretamente numa dada situação". Por outro lado, médicos tenderiam a considerar acidentes como sinônimo de "lesão". Apesar do tom de crítica aos psicólogos na citação acima, esse autor adota a seguinte definição de acidente: "resultado não planejado de um comportamento impróprio". Sua opção por esta definição é justificada nos seguintes termos:

a) diferencia o comportamento antecedente de sua conseqüência;

b) enfatiza a natureza de evento não planejado mais que a de não previsível;

c) o comportamento antecedente é denominado não apropriado, quando analisado em relação às demandas atuais da tarefa e do ambiente;

d) evita a associação entre "acidente" e "acaso", que, muitas vezes, dificulta a distinção de relação entre o comportamento antecedente e o resultado do acidente.

Carmo e col. (1995) e Almeida (1996) reviram teorias de causalidade de acidentes presentes na literatura, destacando as seguintes: 
- Teoria do puro acaso

- Teoria da propensão tendenciosa

- Teoria da propensão inicial desigual ou da propensão ao acidente

- Teoria do ajuste / estresse ou da acidentalidade

- Teoria do alerta

- Teoria do dominó

- Teorias psicanalíticas ou da motivação inconsciente

- Teorias sistêmicas ou situacionais

- Teorias epidemiológicas

- Da fiabilidade de sistemas

- Da gestão integral de segurança

Nessas teorias, evidencia-se predomínio de abordagens psicológicas, com maior difusão daquelas que enfatizam o estudo de comportamentos no trabalho. Segundo Dejours (1997), o encaminhamento da investigação acerca do papel do fator humano nos acidentes assume dois caminhos: o da falha humana e o dos recursos humanos. Do ponto de vista prático, o primeiro prioriza a abordagem de falhas, desrespeito a regras, erros ou faltas cometidas no trabalho e a defesa de regulamentos, da disciplina, da vigilância e de instruções direcionadas para o controle das ações.

A teoria do dominó, esboçada por Heinrich (1959) na década de 30, apresenta o acidente como último evento de uma seqüência linear e corresponde à tentativa de sistematização do processo acidente, que se contrapõe à noção de fatalidade supracitada. Nessa teoria, o acidente é representado por série de 5 pedras de dominó, 
posicionadas de tal maneira que a queda de uma desencadeia a das demais colocadas à sua frente.

A terceira pedra da série introduziu a noção de atos inseguros e condições inseguras como fatores que precedem diretamente a ocorrência do acidente propriamente dito e a da lesão. De acordo com a teoria nas origens imediatas do acidente, as ações do trabalhador (ou de seus colegas) - atos inseguros - assumem papel de destaque a ser contemplado na prevenção. Atualmente, essa é uma das noções de causa de acidentes mais difundidas no Brasil e no mundo.

Embora a teoria do dominó descreva o acidente como seqüência linear de eventos, sua difusão destaca a dicotomia ato inseguro/condição insegura, que também aparece referida como fator humano/fator técnico. A maioria das publicações brasileiras destinadas a profissionais que atuam no campo da saúde e segurança do trabalho, editadas sob os auspícios da Fundacentro, difunde essa concepção de causa de acidentes e define como objetivo de sua investigação a identificação de atos e/ou condições inseguras.

Binder e col. (1997) e Almeida e col. (2000) consideram que a adoção de práticas de investigação de acidente baseadas nessa teoria contribuiu para a difusão de procedimentos de atribuição de culpa às vítimas de acidentes do trabalho no Brasil. As investigações estudadas eram sucintas e mostravam, em média, menos de 2 fatores causais por acidente. A importância assumida por essa concepção será discutida mais adiante, nesta tese.

\subsection{Multicausalidade, rede de múltiplas causas em interação, erro humano, aprendizado organizacional e compromisso cognitivo}

Nos últimos 30 anos, a literatura de acidentes do trabalho consagra concepção multicausal, ampliando os horizontes a serem explorados numa investigação de acidentes e diminuindo a importância atribuída anteriormente às causas imediatas desses eventos. 
O surgimento da concepção multicausal enseja o aparecimento de novos métodos de investigação. Monteau (1979) classifica os métodos de investigação de acidentes em dois grupos: os baseados em questionário contendo lista fechada de possíveis fatores causais previamente identificados e os denominados hermenêuticos, que adotam busca aberta de possíveis fatores causais sem definição de causa "a priori”.

A exploração de relações ou interações entre fatores de acidentes também é citada como caraterística de técnicas ou formas assumidas em investigação de acidentes. Partindo-se dessa característica, esboça-se, a seguir, apresentação de duas formas que essas investigações podem assumir.

A primeira delas explora os múltiplos fatores na forma de lista, sem qualquer preocupação com a exploração de relações ou interações entre eles. A segunda explora "causas das causas", procurando desenvolver a investigação até o esgotamento das informações possíveis com os recursos disponíveis no sistema, ou até o esclarecimento de aspectos considerados importantes na gênese do acidente, ou, ainda, até o momento em que se considere que já estão evidenciados fatores suficientes para embasar a adoção de decisões relativas à prevenção de acidentes assemelhados ao analisado. Nessa abordagem, a busca de fatores baseia-se na interação por eles assumida na origem do acidente. Essas concepções são adotadas em diversas técnicas de investigação de acidentes, inclusive aquelas que adotam representação gráfica desses fenômenos.

Alguns métodos foram concebidos para investigação de riscos "a priori” e, em alguns sistemas sócio-técnicos abertos ${ }^{1}$ de baixa acidentalidade, passaram a ser usados também em investigações de acidente ("a posteriori”). Em geral, trata-se de métodos baseados em questionários exaustivos, buscando propiciar reconstrução de falhas técnicas, gerenciais e/ou riscos assumidos que tenham contribuído em qualquer etapa do acidente, seja em suas origens tardias, seja no agravamento de lesões após o acidente propriamente dito.

\footnotetext{
${ }^{1}$ Vide figura 1.
} 
Assim é que, por exemplo, o método "Management oversight risk tree" (MORT), em sua versão completa, inclui esquema de fatores classificados por tipo, mas sem exploração de relações entre eles. A versão simplificada desse método adota questionário de perguntas fechadas e também constitui exemplo de técnica do primeiro grupo.

O método de árvore de causas adota coleta de fatos aberta, baseada na busca de origens de fatores do acidente, e a lista de fatos elaborada a seguir visa a organizar os achados de modo a facilitar sua utilização na montagem da árvore. Nessa etapa, as relações entre fatores são retomadas e servem de espinha dorsal da análise.

Essa segunda vertente da investigação beneficia-se da adoção de compreensão do acidente como sinal da ocorrência de uma disfunção em sistema sócio-técnico aberto. Num primeiro momento, adota-se a idéia de que investigar um acidente significa identificar o que mudou no sistema - em comparação com o seu funcionamento sem acidente - e continuar a exploração até a localização das condições do sistema ou, mais precisamente, das interações entre seus componentes técnicos e sociais que permitiram a origem dessas mudanças. Aqui, a noção de multicausalidade assume a forma de rede de múltiplos fatores em interação.

A figura 1 mostra esquema de sistema sócio-técnico aberto e seus componentes. As instalações, equipamentos, ferramentas, matérias-primas, fontes de energia, etc., são os componentes técnicos escolhidos pelos proprietários e chefias do empreendimento. Esses componentes sofrem influência (e influenciam) dos objetivos de produção, da situação de mercado - especialmente suas flutuações temporais -, da legislação vigente, de relações sociais estabelecidas entre empregados, seus organismos de representação e empregadores e de relações entre empregadores e organismos sociais de defesa de direitos sociais e individuais (defesa do meio ambiente, dos consumidores, das crianças e adolescentes, etc.).

Nesse esquema, ilustra-se a interação dinâmica de componentes técnicos e sociais para a obtenção de produto ou resultado, num determinado contexto exterior e período de tempo. De modo geral, é raro encontrarem-se descrições de sistemas que 


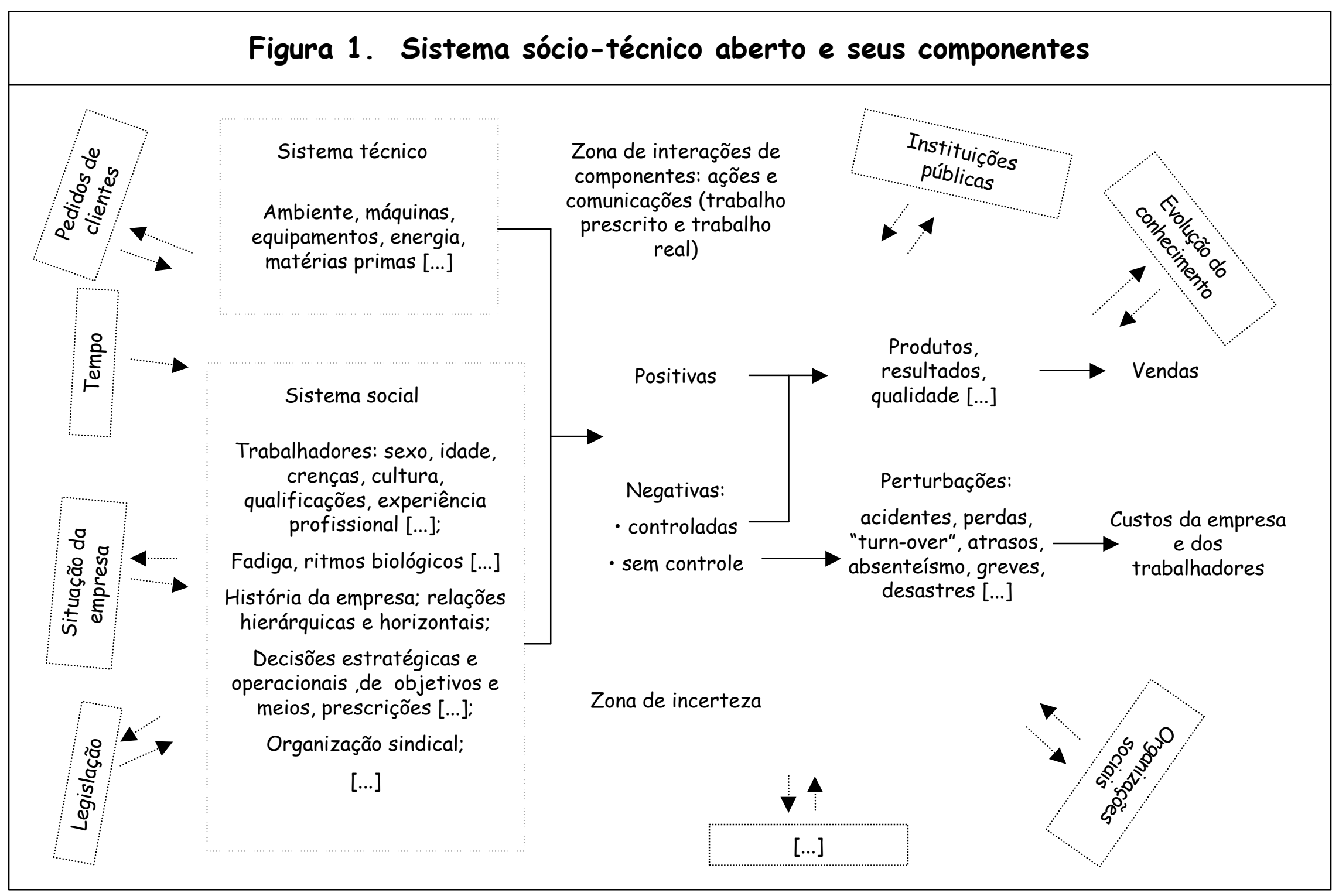


apontem também a influência que este último fator tem sobre componentes (técnicos e humanos) e interações ocorridas no sistema. No entanto, no campo da saúde e trabalho, trata-se de aspecto de grande importância que precisa ser sempre lembrado.

Os trabalhadores que vão atuar no sistema estabelecem relações entre si, com suas chefias e empregador(es). Cada um deles possui histórico de vida pessoal e profissional próprio e, de acordo com esses antecedentes e aqueles de suas comunidades de origem e de inserção da empresa, as relações sociais estabelecidas no sistema assumem características próprias que interferem nas relações assumidas entre empregados e chefias e empregados e meios disponibilizados no sistema para o desenvolvimento de sua atividade.

Quando os trabalhadores iniciam sua atividade, não o fazem com liberdade de escolha. Os meios utilizados são aqueles previamente determinados. Além disso, as chefias estabelecem os objetivos e metas de produção, definem prescrições, horários, a divisão das pessoas em equipes ou trabalho isolado, etc.

$\mathrm{Na}$ atividade, se as interações entre trabalhadores e meios disponíveis ocorrem de acordo com o planejado, elas são consideradas positivas, e as saídas do sistema correspondem, por exemplo, em qualidade e quantidade, às pretendidas. No entanto, sempre existem interações definidas como negativas devido ao fato de seus resultados não serem os planejados. Uma vez ocorrida a mudança, os trabalhadores, individual ou coletivamente, desencadeiam tentativa de recuperação, que pode corrigir o problema ou ensejar novas perturbações que, quando não restauradas, geram acidentes e/ou outras perdas para o sistema.

A adoção de classificações dos componentes de sistemas e o surgimento da noção de modelo de acidente representam elemento auxiliar do processo de condução da investigação. Exemplo simples de classificação de componentes é o adotado no método de árvore de causas, que divide a atividade realizada em indivíduo (I), tarefa (T), material (M) e meio de trabalho (MT), também chamado de ambiente (A). As noções de modelo procuram esquematizar os elementos presentes no acidente, sendo as mais conhecidas baseadas na idéia de que o acidente envolve encontro entre um 
indivíduo exposto e uma energia perigosa que, até então, encontrava-se sob controle, mas que foi liberada no evento. De acordo com esse ponto de vista, investigar um acidente implica identificar: a) o tipo de encontro, ou seja, de energia liberada e da forma que vem a atingir o exposto, e suas conseqüências; b) as condições que explicam a existência do indivíduo exposto; c) as razões da existência do perigo ou energia potencial no sistema; d) os fatores associados à liberação da energia que estava sob controle. Alguns modelos acrescentam análise de existência e/ou de razões da insuficiência de barreiras ou medidas de proteção que deveriam conter o perigo e/ou impedir ou minimizar as consequiências da ocorrência do encontro.

As classificações de componentes do sistema auxiliam, sobretudo, o uso de métodos baseados em listas de fatores, mas não só. Afinal, sua utilização, juntamente com a noção de modelo, contribui para a sistematização do procedimento adotado e para a ampliação de seu perímetro pelo menos até aquele da dimensão do conjunto de fatores incluídos na lista ou no modelo.

Segundo Kouabenan (1999a , p.21-22), em investigações de AT, adota-se perspectiva de descrição do mecanismo causal ou de produção de ocorrências que não deveria ser confundida com a possibilidade de predição desses eventos. A utilização da expressão fatores de acidentes exprime escolha feita por diferentes autores, inclusive os criadores do método ADC, como decorrência da opinião que não se poderia falar de causa(s), quando sua presença não fosse suficiente para explicar ou desencadear o AT.

De acordo com esse entendimento, causa é o resultado de uma combinação de fatores tidos como necessários e suficientes para explicar o mecanismo de origem de um acidente, cuja investigação nunca pode considerar-se esgotada. Por outro lado, a amplitude assumida por essa investigação recebe influência de rede de outros fatores internos e externos da empresa, como, por exemplo, o estágio de segurança já atingido, aspectos socioculturais e políticos, etc. 
As abordagens sistêmicas atribuem importância especial à noção de mudança no curso da atividade e, em particular, aquelas mudanças capazes de introduzir uma perturbação na forma de desenvolvimento habitual ou cotidiana dessa atividade. É a abordagem das ações ou comportamentos humanos no trabalho que vai permitir a elucidação dessas mudanças e subsidiar os caminhos a serem adotados na prevenção de acidentes. Na literatura, evidenciam-se formas diversas de abordagem dessas ações: há autores que tipificam erros humanos (Rassmussen e col. 1987; Kirwan 1992a, 1992b) e buscam identificar os tipos de erros em acidentes; outros, como Hale e Glendon (1987b) e Dejoy (1996), desenvolvem modelos explicativos de comportamentos humanos face ao perigo.

Na corrente comportamentalista, defendem-se o desenvolvimento de cultura de segurança e a utilização dos acidentes como fonte de aprendizado organizacional.

Os elementos que caracterizam a existência de cultura de segurança são: a) identificação de riscos presentes em cada processo e tarefas associadas; b) avaliação de sua probabilidade e daquela de danos potenciais para pessoas, materiais e meio ambiente; c) adoção de medidas de controle; d) documentação de todo o processo para cada um dos riscos; e) disponibilização gratuita da documentação para todos os interessados, revisão periódica e face a circunstâncias (mudanças de equipamento, níveis de manutenção, etc.); f) avaliação de risco, pelos membros da equipe, antes do início de qualquer tarefa (identificar risco, adotar controles); g) demais membros da organização conhecem, encorajam e dão suporte a essas medidas (Cooper 1999).

Por sua vez, o processo do aprendizado organizacional (Freitag e Hale 1997) considera que dada a ocorrência de acidente sua análise deve responder às seguintes questões:

a) Por que o planejamento e as avaliações existentes não identificaram o risco em questão?

b) Por que seu controle não foi priorizado?

c) Houve definição de responsável por este controle? 
d) A comunicação foi adequada?

e) As metas do sistema de gestão (da produção, da segurança etc.) eram conflitantes?

f) Por que não foram alocados recursos adequados?

g) Os desempenhos e comportamentos esperados foram adequadamente recompensados?

Outros autores, como Sperandio (1996, p. 188), adotam definição de confiabilidade sistêmica baseada justamente nas capacidades e habilidades dos trabalhadores para corrigir essas perturbações: "não é somente não cometer erros, mas também fazer o gesto adequado, tomar a iniciativa que convém no momento, recuperar um erro da máquina ou de outro operador". Na literatura de Ergonomia, essa noção tem larga difusão, sendo adotada em estudos da confiabilidade humana em sistemas avaliados como dotados de boa segurança, especialmente no tocante aos seus componentes técnicos. Além disso, ela contrapõe-se àquela que atribui às ações do trabalhador o papel exclusivo de responsável pela ocorrência de acidentes.

Em 1990, Reason $\left(1999^{2}\right)$ introduz as noções de erros ativos, cometidos pelos executantes ou operadores que atuam na linha de frente das empresas e que têm consequiências imediatas, e de erros latentes, cometidos pelos idealizadores, pelos responsáveis por decisões de alto nível, pelos construtores do sistema, diretores ou pessoal de manutenção e cujas conseqüências podem ficar "adormecidas" por muito tempo no sistema. Segundo ele, entre os integrantes da comunidade que atua na área da confiabilidade humana cresce a consciência de que os esforços empreendidos para descobrir e neutralizar os erros latentes têm resultados mais benéficos (na confiabilidade do sistema) do que as tentativas pontuais de reduzir erros ativos.

Ele desenvolveu modelo de acidente baseado justamente na ultrapassagem de diversos níveis de barreiras ou placas de proteção. De acordo com esse autor, o 
acidente advém quando as brechas nas diversas placas se dispõem de tal maneira que este evento pode atravessar todas elas e eclodir no sistema (Reason 1999). Nessa abordagem, a existência das múltiplas barreiras é tomada como dado "a priori”, e sua ausência é considerada como um fator de acidente, mesmo que inexistisse desde a concepção e montagem do sistema. Nesse sentido, adota-se como padrão a prescrição e não a atividade ou trabalho realmente desenvolvido por ocasião do acidente.

$\mathrm{Na}$ abordagem da Ergonomia, enfatiza-se a diferença entre trabalho real e trabalho prescrito ou tarefa. Autores franceses introduzem o conceito de atividade, ampliando o sentido originalmente dado à noção de atividade cotidiana, trabalho habitual, ou trabalho normal. Aponta-se o equívoco possível na investigação, quando se perde de vista a diferença entre atividade (trabalho real) e tarefa (trabalho prescrito), adotando-se como padrão para identificação de mudanças o trabalho prescrito e/ou as normas vigentes no sistema. Indo mais além, explicita-se compreensão de que na atividade ou trabalho real estão sempre presentes eventos que se traduzem em variabilidade, exigências diversas, incertezas de situações que escapam ou ultrapassam a norma (Guérin e col. 1997; Bourgeois e col. 2000), e não que se distanciam dela, como propõe a abordagem comportamentalista ou prescricionista. De acordo com essa visão, trabalhar é fazer face a esses eventos que são parte integrante e inseparável da situação, sendo singulares e dotados de capacidade de mudar a situação (Bourgeois, Lemarchand, Hubault e col. 2000).

Bourgeois e col. (2000) adotam o conceito de gesto para indicar o que o indivíduo faz para fazer face a esses eventos, confrontando-se com a organização do trabalho. O gesto não é o resultado da livre escolha do operador, e, sim, de compromisso firmado entre os objetivos, a tarefa, os meios de trabalho e as características do indivíduo que realiza esse gesto. A competência corresponde justamente ao saber encontrar o "bom compromisso", ou seja, a aquisição de habilidades e estratégias gestuais individuais e coletivas. É por isso que os gestos de cada pessoa são diferentes, inclusive daquelas que tiveram formação semelhante.

2 A primeira edição da obra de Reason, em inglês, é de 1990. A edição consultada pelo autor e citada na tese é de 1999. 
Nesses casos, pode-se falar de mesmo grupo ("rassemblence") ou de gestos assemelhados, mas não de mesmos gestos e, fazendo o paralelo, mesmos acidentes.

Amalberti (1996, p. 220) refere-se à gestão dessas situações de regulação do trabalho adotando o conceito de compromisso cognitivo forjado na atividade. Partindo de crítica aos primeiros estudos do erro humano, aponta o fato de que esta noção tende a ser compreendida como falhas dos operadores a serem tratadas por melhorias de formação e por aperfeiçoamentos da regulamentação das tarefas. Para Amalberti, aqueles que ressaltam a falha dos operadores esquecem que "os acidentes/incidentes graves são raros, e que muitos acidentes (infelizmente sem estatísticas a apoiá-los) são evitados graças aos atores do sistema” (p. 220).

Segundo ele, a compreensão do erro humano em Reason vai além dessa anterior, representando "revés a ser pago à inteligência humana" e "que não pode ser totalmente erradicado, qualquer que seja a formação, o tratamento ergonômico ou a regulamentação [...] ele resta na origem de necessidades de segurança e tudo deve ser feito para conseguir sua redução".

Partindo do reconhecimento da inevitabilidade do erro, Llory (19) passa a defender a necessidade de mudança do enfoque proposto nas abordagens de erro humano. Segundo ele, deve-se adotar justamente a idéia de que "errar é humano".

A idéia central da obra de Amalberti é que o compromisso cognitivo sobrepõe-se ao erro (p. 42 e seguintes). Ele reintroduz o erro no conjunto dos processos cognitivos do operador, que, por sua vez, é visto como "inteligente, extraordinariamente flexível e adaptável e, ao mesmo tempo, frágil e limitado em seus processos cognitivos". O autor ainda destaca que o operador é dotado de metacognição, ou seja, ele conhece suas limitações, dispõe de visão reflexiva acerca de suas próprias capacidades, isto é, sabe o que sabe e o que não sabe. Na visão do autor, esse conhecimento representa uma série de proteções ou almofadas (“couches"), na forma de uma cognição dinâmica, que confere eficácia e segurança ao sistema (p. 221). 
O modelo proposto por Amalberti completa-se com a noção, não apontada por Reason em seu modelo de placas, de interação entre essas proteções ou almofadas. Essas interações são dirigidas pela cognição e pela confiança, assegurando a coerência global do modelo.

"Em resumo, este sistema está em permanente retroalimentação ("bouclé”), com um um retorno de informações que permite uma tomada de consciência do compromisso produzido e um ajuste permanente das intenções e das proteções usadas em função do nível de desempenho observado naquele dia, para aquele caso.” (p. 221)

A complexidade crescente dos sistemas de alta tecnologia pode ser o elemento de desequilíbrio do desempenho do operador. Ela pesa como um desafio a seu saber, colocando-o em confronto com um sistema que ele sabe que não compreende na sua totalidade. Gerir um sistema que ele sabe compreender apenas de forma incompleta representa um risco próprio a cada operador: dispor de saber suficiente para o nível de desempenho que quer atingir, mas querer compreender melhor a situação. Amalberti introduz a noção de compromisso cognitivo para referir-se à gestão desse risco, gestão que se regula no curso da tarefa, dinamicamente, com uma série de "apostas", de escolhas estratégicas e de táticas locais (p. 43).

“Este compromisso leva em conta uma representação do risco externo de acidente para o procedimento em curso, do nível de exigência do resultado a atingir, uma representação de seus próprios recursos, de seu estado de fadiga, de suas capacidades e, sem dúvidas, de outros elementos.” (p. 43)

Essa forma de compreender o trabalho leva Amalberti (1996) à idéia de que a falha dos operadores se exprime em primeiro lugar pela perda de controle desse compromisso cognitivo, antes de ser uma perda de controle do sistema físico. A ocorrência de um erro tanto pode aceita pelo operador, de acordo com o compromisso que escolheu, como contribuir para o aperfeiçoamento do seu compromisso, jogando papel positivo de sinal, dentre outros, ou ainda servir como revelador efetivo da perda de controle do compromisso. Lima e Assunção (citados por Baumecker 2000, p. 109) concordam com essa opinião e afirmam que "os 
acidentes podem nos apontar como os compromissos cognitivos foram rompidos e não no que eles consistem".

Esse último caso constitui uma nova forma de conceber o acidente em sistemas técnicos de alta complexidade que se tornaram mais seguros, apresentam baixa freqüência de acidentes, e acidentes residuais que são potencialmente mais graves. As taxas de frequiência de acidentes nesses sistemas estabilizaram-se em torno de valores muito baixos, cuja representação gráfica corresponde a platô próximo de zero. A persistência desses valores praticamente inalterados é descrita como estagnação da prevenção. Isso significa que as lições tiradas da investigação desse tipo de acidentes não fornecem subsídios para a melhoria da segurança medida pela taxa de freqüência de acidentes. Por isso, o autor propõe "o deslocamento da análise para as regulações operatórias das situações normais”3.

Considerando a afirmação de que a possibilidade de ocorrência dos acidentes está contida no sistema que os pode gerar, Baumecker (2000) descarta a possibilidade de referir-se a eles como "fenômenos imprevisíveis", obras do acaso que só se revelariam "a posteriori”, mantendo em si o princípio da indeterminação. A autora também descarta a visão determinista, segundo a qual os acidentes poderiam ser previstos com certeza absoluta. Para ela, a questão é: "se a situação de trabalho 'contém' o acidente será possível compreendê-lo e evitá-lo antes de sua ocorrência [...]"? (p. 113). Neste estudo, discute-se questão diferente da proposta pela autora e que pode ser formulada nos seguintes termos: dado que a situação de trabalho contém o acidente, está mantida a validade e a utilidade da investigação desses eventos? O tipo de acidente (1, 2 ou 3 de Monteau) mais freqüente numa dada realidade interfere na resposta a essa questão?

\subsection{A concepção predominante no Brasil}

No Brasil, as empresas que empregam trabalhadores de acordo com as regras preconizadas na Consolidação das Leis do Trabalho adotam definição jurídica de

\footnotetext{
${ }^{3}$ Lima, FPA 2000. (Correspondência ao autor).
} 
acidente do trabalho constante na legislação previdenciária: "aquele que ocorre pelo exercício do trabalho a serviço da empresa, provocando lesão corporal ou perturbação funcional que cause morte, perda ou redução, permanente ou temporária, da capacidade para o trabalho" (Paixão 1991). Assim, ocorrido um acidente em que a vítima é vinculada ao seguro de acidente do trabalho, o Departamento de Pessoal da empresa emite comunicação de acidente do trabalho (CAT), encaminhada à Previdência Social, com cópia para outros organismos públicos. Além disso, por força de obrigações definidas na legislação trabalhista vigente, setores da empresa procedem à investigação do acidente.

As estatísticas oficiais de acidentes do trabalho são elaboradas com base nas CATs e, apesar da precariedade das informações disponíveis e de suas limitações no que tange ao dimensionamento do real impacto do trabalho sobre a saúde, mostram que sua ocorrência assume dimensão alarmante. Assim é que, de 1981 a 1990, foram registrados junto à Previdência Social 10.374.247 acidentes do trabalho, dos quais 254.550 resultaram em invalidez e 47.251 em óbitos (Binder e Almeida 1997).

Na nova versão da Norma Brasileira 14280 (NBR 14280), a Associação Brasileira de Normas Técnicas (ABNT) adota definição bastante semelhante à da legislação, embora se refira também a eventos sem vítimas: "Acidente de trabalho é a ocorrência imprevista e indesejável, instantânea ou não, relacionada com o exercício do trabalho, que provoca lesão pessoal ou de que decorre risco próximo ou remoto dessa lesão".

Nesses dois casos, legislação trabalhista e Norma Brasileira, a exploração de causas predominantes baseia-se na noção introduzida pela terceira pedra da seqüência linear proposta por Heinrich: atos inseguros e condição insegura. Por vezes, as denominações usadas assumem pequenas mudanças: atos e/ou condições abaixo do padrão, condição ambiente de insegurança. Na versão assumida na Norma Brasileira, enfatiza-se a exploração da condição pessoal de insegurança, que, na sequiência das pedras do dominó, aparece como aquela que dá origem ao ato inseguro. 
Segundo Baumecker (2000), apesar de a ideologia dominante estabelecer a causalidade, negando o acaso, o que vimos na prática da Engenharia de Segurança é uma ação superficial ligada à anormalidade do evento acidente (p. 114), retornando à noção de fatalidade "contra a qual os homens nada podem fazer, apesar dos sinais manifestos aos quais não é dada a devida importância” (p. 114).

O contraste acima mostrado entre a evolução da noção de acidente e a de estudos dedicados à sua investigação e a forma assumida por essas mesmas noções e as práticas de investigações recomendadas na legislação e pelos organismos de assessoria empresarial pode ser assumido como indício de pertinência da questão apontada no início deste texto. Além disso, remete-nos a novas questões acerca de razões e consequiências dessa dessincronia. Antes de explorá-las, introduzem-se outros conceitos abordados na discussão de investigações de acidentes.

\subsection{Tipologia de acidentes e acidente normal}

Partindo do pressuposto de que a ocorrência de acidente implica na existência de pelo menos uma mudança, denominada variação, em relação à situação de trabalho cotidiana ou sem acidente, Monteau (1992) propôs classificação de acidentes que será usada neste estudo. A identificação dessa variação deve ser feita com base em comparação com a situação de trabalho real e não em relação à tarefa entendida enquanto trabalho prescrito.

Os acidentes de tipo 1 são aqueles desencadeados pela presença de uma variação na situação cotidiana de trabalho ou que resultam de sequiência linear de fatores desencadeados a partir dessa variação. Em outras palavras, trata-se de variação cuja presença, isoladamente, gera perturbações ou interações negativas que resultam no acidente. Os acidentes de tipo 1 são mais freqüentes que os demais e acontecem em atividades habituais, envolvendo condições ligadas ao posto de trabalho e que são realizadas com o uso de componentes estáveis ou permanentes do sistema, facilmente identificados como de risco evidente. Nesses sistemas, em geral, a confiabilidade e a segurança baseiam-se quase que exclusivamente no desempenho dos trabalhadores na atividade. 
Os acidentes de tipo 2 são aqueles em cujas origens participam conjunções de pequeno número de variações, ou seja, cujo desencadeamento necessita da presença de fator(es) mudança que, isoladamente, não leva(m) ao acidente, mas que, em associação com outro fator mudança de origem independente da sua, tornam-se suficientes para a ocorrência do AT. Trata-se de acidentes de ocorrência esporádica, menor que aquela dos de tipo 1, envolvendo interferências organizacionais na atividade e situações de aparecimento limitado no tempo.

Por fim, os acidentes de tipo 3 são aqueles cujas origens exigem a presença de conjunções de numerosos fatores variação de origens independentes entre si. Segundo Monteau, esses acidentes são de ocorrência excepcional, resultando de acumulação de erros ou afastamentos de regras e/ou procedimentos em sistemas dotados de política de gestão da segurança e que já resolveram problemas considerados clássicos para a Engenharia de Segurança. Isoladamente, as variações em questão podem não representar ameaça à segurança, mas, ao interagirem com as demais, levam ao acidente.

Embora Monteau não discuta esse aspecto, pode-se afirmar que a noção de acidente de tipo 3 inclui acidentes que equivalem ao acidente normal ou acidente sistêmico ("system accident") proposto por Perrow (1999 ${ }^{4}$ ), em 1984. Segundo o autor, uma das características de sistemas considerados de alto risco - como aqueles em que está presente a possibilidade de liberação de substâncias tóxicas, de explosões ou riscos associados à utilização de técnicas genéticas - é a possibilidade de acidentes inevitáveis ou "normais". Na origem desse tipo de acidentes, estariam características como a complexidade interativa ("interative complexity") e a estreita interligação ("tightly coupled") dos fatores envolvidos. Nas palavras do autor, a expressão acidente normal significa que

“[...] dadas as características do sistema, interações de falhas múltiplas e inesperadas são inevitáveis. Isto é, uma expressão de uma característica integral do sistema, não uma afirmação de freqüência" (Perrow 1999, p. 5).

\footnotetext{
${ }^{4}$ A primeira edição da obra de Perrow é de 1984. As referências nesta tese baseiam-se na edição de 1999.
} 
Isso significa que, nesses sistemas, sempre está presente a possibilidade da ocorrência de falhas capazes de desencadear interações que ocorrem com tal rapidez que não podem ser interrompidas ou isoladas de outras partes do sistema e que impedem a continuidade da produção de modo seguro. Além disso, nem as melhorias organizacionais, nem as inovações tecnológicas diminuem a propensão desses sistemas a acidentes.

Por isso, as causas dos acidentes devem ser buscadas na complexidade do sistema. Além disso, as falhas que estão na origem desses eventos são consideradas triviais ou sem significado para a segurança, quando presentes de modo isolado. Cada uma delas dispõe de um sistema de "backup" ou de correção redundante. Elas se tornam perigosas quando interagem de modo inesperado e incompreensível, durante um certo período de tempo considerado crítico. "É a interação de múltiplas falhas que explica o acidente" (Perrow 1999, p.7).

A noção de complexidade adotada por Perrow (1999) considera os tipos de interações entre fatores que predominam no sistema. Interações lineares são aquelas que ocorrem numa seqüência de produção ou manutenção esperada e familiar, sendo visíveis mesmo que não planejadas. Trata-se de interação de um componente com um ou mais componentes que o precedem ou o seguem na seqüência de produção. Interações complexas são aquelas de sequiências não familiares, não planejadas e inesperadas, além de não visíveis e não imediatamente compreensíveis, em tempo real para os operadores (p. 74).

Com base no grau ou quantidade de cada tipo dessas interações presentes no sistema, mas considerando também outras de suas características, como a distribuição espacial dos processos, as possibilidades de substituição de componentes ou etapas do processo e a existência de retroalimentação, por exemplo, o autor classifica os sistemas em lineares e complexos (p. 88). Ele destaca que interações lineares predominam em todos os sistemas, que mesmo o sistema "mais linear" pode, ocasionalmente, apresentar interações complexas e que, para compreendermos o sistema, precisamos ir além dessa distinção entre tipos interações. 
Perrow (1999) adota definição de incidente e acidente considerando divisão do sistema em que este evento ocorre em quatro níveis de agregação crescente: unidades, partes, subsistemas e sistema. Incidente envolve dano ou falha de partes e/ ou unidades do sistema, enquanto que, no acidente, há dano para subsistemas e/ou para o sistema inteiro. Merece registro o fato de que essa definição não inclui referência à existência ou não de vítimas. De acordo com o entendimento do autor, a existência de um trabalhador lesionado só implica em acidente se esse trabalhador, em si, constituir um subsistema.

Em pós-escrito incluído na edição de 1999, Perrow distingue a existência de acidentes de dimensões catastróficas que não podem ser chamados "acidentes normais", como, por exemplo, o acidente ocorrido em dezembro de 1984, em fábrica da Union Carbide, em Bhopal, Índia. Naquele caso, a empresa convivia com grande quantidade de problemas reconhecidos como ameaça à segurança, previamente identificados em inspeções e, mesmo assim, deixados como tal, sem a adoção de nenhuma providência. A ocorrência do acidente não dependia, portanto, de interações complexas e inesperadas (Perrow 1999, p. 355). O esclarecimento da natureza dos fatores que interagem nesse AT permite classificá-lo como de tipo 3, de Monteau.

As investigações que se baseiam em concepção multicausal de acidentes e aquelas que exploram o processo causal buscando esclarecer rede de múltiplos fatores em interação costumam exigir formação adequada da equipe encarregada das análises. A implantação da técnica, nas empresas, deve ser precedida por etapa de negociações entre os diversos atores e setores da empresa, de modo a explicitar as razões de sua utilização e as contribuições esperadas de cada um deles. Além disso, a condução de cada análise costuma ter duração maior que aquela habitualmente dedicada a essa atividade nas empresas, e a exploração dos achados obtidos, particularmente daqueles de natureza gerencial e da organização do trabalho na empresa, nem sempre é possível, resultando, por vezes, em desestímulo da equipe de investigação.

Esse conjunto de exigências mostra que a mudança de concepção de acidente e a adoção de técnica de investigação de base sócio-sistêmica por parte de uma 
empresa ou instituição não podem e não devem ser confundidas com processo isento de dificuldades. Por isso mesmo, vem à tona discussão acerca da indicação de seu uso ou introdução. A questão diz respeito à necessidade da adoção de procedimentos de investigação que se mostrem coerentes com a realidade de segurança a ser enfrentada.

Isso significa que métodos mais sofisticados são indicados para utilização, principalmente em situações em que há predomínio de acidentes do tipo 3, de Monteau, ou em que os componentes técnicos do sistema, o arranjo físico, a organização do ambiente e os modos operatórios nele adotados são considerados seguros à luz dos conhecimentos existentes. É obvio que a utilização de técnica de investigação que explora grande quantidade de fatores causais, na análise de um acidente de tipo 1, de Monteau, pode evidenciar, inclusive, problemas de segurança que extrapolam os limites daqueles mais evidentes. Também é plausível a adoção desse tipo de proposta como parte de objetivos institucionais que vão além da abordagem estrita do acidente. Sabe-se, por exemplo, que sindicatos de trabalhadores se interessam pelo uso de árvores de causas porque essas se mostram úteis na comunicação acerca do acidente e, consequientemente, no enfrentamento de práticas de atribuição de culpa aos trabalhadores vitimados.

Do exposto, surgem novas questões ou problemas que, a nosso ver, justificam estudo como o proposto nesta tese: as empresas estudadas classificam os tipos de acidentes nelas ocorridos?; as práticas de investigação adotadas diferenciam-se em função de eventual classificação ou de algum outro procedimento adotado pela empresa?; o tipo de acidente que predomina numa empresa influencia os achados da investigação aí realizada?

\subsection{Investigação de acidentes do trabalho: importância, limites e questionamentos}

Para muitos leitores ou interessados na prevenção de acidentes, referir-se à importância da sua investigação pode parecer coisa óbvia. No entanto, como se mostra a seguir, embora a maioria dos autores estudados reconheça a importância 
dessa prática e recomende sua adoção, muitos são os que discutem limites e/ou falhas nela existentes, e há até quem negue a existência de qualquer benefício associado a esse procedimento.

Lieber (1998) defendeu essa última idéia. Em sua tese, ele conclui que as teorias e métodos de investigação de acidentes:

- estão voltados à viabilização das condições perigosas de trabalho ou da “condição do trabalho moderno no homem", reforçando a "iniqüidade e a exclusão de ações transformadoras favoráveis à promoção da condição humana" (Lieber 1998, p. 271-2);

- sustentam-se no ideal ascético, assumindo "necessidade da disciplina como pressuposto geral" (p. 272) e inviabilizando a redução do sofrimento.

Segundo Lieber (1998), teorias e métodos de investigação de acidentes fundem "causalidade" com "responsabilidade", baseando-se sempre na investigação de erros, e não de causas, e assumindo a necessidade da disciplina como pressuposto geral (p. 271-2). Para o autor, a noção de erro associa-se à idéia de violação de regras de segurança, normas ou padrões prescritos de trabalho, o que, por sua vez, implica na defesa de pressuposto de que o existente é conhecido e caracterizado por uma ordem que a investigação de acidente nunca questiona e, até pelo contrário, busca sempre preservar.

É importante apontar que, de acordo com Lieber, o conceito de variação ou mudança adotado em alguns métodos e técnicas de investigação implica sempre na adoção dessa noção de erro associada à idéia de violação de regras, normas ou padrões prescritos.

Para ele, "causa", no sentido "de produzir ou efetivar, não pode ser atribuição do contexto, o qual existe e persiste mesmo em condições de não-acidente. Logo, embora o contexto possibilite o acidente, ele em si não é causa" (Lieber 1998, p. 263). Em outros momentos, o autor explicita sua opinião: “só o acaso justifica-se 
como causa" (p. 260). E, mais adiante: "O acidente de trabalho, por definição, é um acidente, ou seja, não cabe um fim mesmo [...]” (p. 227). De acordo com essa visão, o acidente só se revela “a posteriori”. Retorna-se à concepção fatalista e nega-se importância à investigação.

Opiniões diferentes dessa de Lieber são registradas na literatura, ressaltando a importância de investigações de acidentes bem conduzidas, seja para a prevenção de eventos assemelhados, seja para a prevenção de perdas materiais (Haddon 1968; Hale e Hale 1972; Johnson 1973; Leplat e Cuny 1979; Méric e Szekely 1980; Leplat 1985; Hale e Glendon 1987e; Nolter e Johnson 1987; Pham e Monteau 1989; Simard 1989; Kletz 1993; Llory 1996; Menkel e Kulinger 1996; Hale e col. 1997; Wilpert e Freitag 1997; CCOHS 1998).

Doos e col. (1994) consideraram válida a introdução de estratégia de investigação aprofundada de acidente. Para eles, a entrevista com o acidentado é a atividade que mais permite aos investigadores acesso a novos conhecimentos. Além disso, o uso da mesma estratégia contribui para a consolidação do grupo de pessoas que trabalha com a prevenção de acidentes.

Os autores esclarecem que o seu estudo tinha finalidade de pesquisa, adotando questionário extenso que exigia tempo prolongado para o preenchimento e, por isso mesmo, era considerado não "amigável". Nesse estudo, os investigadores que se sentiram mais beneficiados pela adoção da técnica proposta foram aqueles que a utilizaram mais de 5 vezes, no período de estudo (Doos e col. 1994).

Harms-Ringdahl (1996) afirma que, na Suécia, a partir da criação da Occupational Accident Research Unit, em 1978, a implantação de projetos para melhoria de investigações de acidentes e quase acidentes mostra resultados favoráveis, como a obtenção de maior número de informações acerca de causas de acidentes, de propostas de prevenção e quedas significativas em proporções de acidentes.

Segundo Hallgren (1996), no começo dos anos 90, cresce a utilização de métodos de análises de riscos e de investigação de desvios. Este último é um modelo 
de construção retrospectiva de acidentes e quase acidentes que também pode ser usado como método de avaliação de riscos e análises de segurança. $\mathrm{O}$ autor destaca que análises de segurança de produção, manutenção, etc., em que ocorre participação de empregados podem reduzir riscos de acidentes.

Na Suécia, a introdução de métodos de análise de riscos e da investigação de desvios e dos quase acidentes associada ao surgimento de pesquisas, tendo como objetivos reduzir o número de acidentes e conseguir locais de trabalho mais bem adequados do ponto de vista ergonômico, é apontada como medida que conseguiu melhorias efetivas da segurança em empresas (HALLGREN 1996).

Comentando acidentes ocorridos com elevador de materiais, em obras de construção civil, Baumecker (2000) defende que "a sistematização de vários acidentes, envolvendo fatores similares, também precisa de métodos próprios, sem os quais as recomendações derivadas [...] podem não trazer a prevenção pretendida" (p. 125). De acordo com a autora, as análises dos acidentes ocorridos não devem ser descartadas, mas conduzidas com "metodologias apropriadas, entre as quais cabe destacar a "árvore de causas"' (p. 125-6).

Ao lado de vantagens e importância de investigações de acidentes na literatura, vários autores apontam a existência de falhas nessas práticas. Destacam-se críticas à ineficácia dos métodos de análise e de prevenção, assim como indicações de que grande parte das investigações fica incompleta, deixa "zonas de sombras" e resulta em atribuição de culpa ao próprio acidentado (Hale e Hale 1972; Wigglesworth 1978; Leplat e Cuny 1979; Booth 1981; Saas e Cook 1981; Dwyer 1984, 1991; Allegrante e Sloan 1986; Dwyer e Raftery 1991; Almeida 1996). Para esses autores, a correção dos problemas citados pode ocorrer pela utilização adequada de métodos de investigação que considerem a empresa como sistema sóciotécnico aberto e que valorizem reconstrução sistematizada do evento, inclusive o resgate de percepções do(s) acidentado(s) e de seus colegas de trabalho.

As questões acima mostram a persistência de problemas não resolvidos na abordagem da investigação de acidentes. Características da equipe de investigação, 
como, por exemplo, de sua formação, técnicas escolhidas e recursos utilizados na condução de análises, da concepção de acidente adotada e difundida na empresa em geral, assumem lugar de destaque entre os fatores explicativos de resultados de investigações. Fatores do próprio fenômeno ou acontecimento - que assumem formas muito distintas, desde violência explícita, inaceitável, marcada por abusivo desrespeito a direitos de cidadania, até eventos cujo mecanismo envolve a participação de elevado número de fatores que, isoladamente, não podem ser interpretados como precursores de acidentes, mas que, em conjunção, atuando simultaneamente, resultam no acidente - também têm sido apontados em tentativas de explicação de resultados dessas investigações. O mesmo tem acontecido com aspectos dos contextos sócio-político e cultural, intra e extra-empresa.

As opiniões citadas nesse item procuram mostrar que o tema investigação de acidentes continua despertando interesse, suscitando discussões, opiniões polêmicas e sendo reconhecido como objeto que merece estudos complementares, tanto acerca das características dessas investigações quanto dos contextos em que ocorrem. Algumas questões sugeridas são: a) Até que ponto podem chegar os registros da investigação obrigatória feita na empresa? b) Em que momento é interrompida a tentativa de reconstrução do acidente, desenvolvida por ocasião da investigação conduzida no interior da empresa? c) Qual ou quais as "regras de parada" da investigação adotadas nessas empresas? d) Quais os fatores associados com a elaboração desses registros? e) A existência de Sesmt, na empresa, diferencia a investigação conduzida pela CIPA? f) Os registros de investigação específica do Sesmt(item 4.12.h da NR - 4) são semelhantes ou diferentes daqueles da CIPA?

A seguir, retoma-se o tema dos resultados ou causas identificadas nas investigações de acidentes com ênfase nas atribuições de culpa e de responsabilidade e nas conseqüências no campo da prevenção desses eventos. Além disso, exploramse investigações conduzidas em empresas, procurando identificar formas de aparecimento dos aspectos citados e daqueles relacionados à sua gênese.

\subsection{As noções de culpa e responsabilidade, na legislação de responsabilidade civil e previdenciária}


A noção de responsabilidade civil refere-se à de reparação de danos e, segundo Lima (1998a), sob influência inicial do Direito Romano e, logo em seguida, do Código Civil francês, proclamou como seu "fundamento [...] a culpa efetiva e provada" (pág 28).

Após discorrer sobre as diversas definições de culpa, na literatura jurídica, Lima a define nos seguintes termos:

Culpa é um erro de conduta, moralmente imputável ao agente e que não seria cometido por uma pessoa avisada, em iguais circunstâncias de fato.

Ela apresenta dois elementos: um, objetivo, que consiste na omissão da diligência comum do homem prudente, avisado, cuidadoso ("bonus pater familias") e outro, subjetivo, que consistiria na consciência do ato, no poder querê-lo livremente, podendo ou devendo prever as suas conseqüências.

Historicamente, essa concepção clássica tem sido criticada por sua estreiteza, e as possibilidades de reparação de danos foram sendo ampliadas, via diferentes formas de extensão do conceito de culpa e, particularmente, sob influência da teoria do risco ou fato criado.

De acordo com Lima (1998a), no campo jurídico, há predomínio de apreciação de culpa relativizada, seja pela "fixação da conduta normal do homem adaptado à vida social, ao ambiente em que vive", seja pela avaliação da capacidade delitual ou imputabilidade moral do acusado como elemento primacial da culpa. Trata-se de determinar se o agente poderia agir, em virtude do estado de sua razão e de sua inteligência, como age o "bonus pater familias".

Para fins de comparação, pela sua semelhança, vale registrar as seguintes referências de caracterização do ato inseguro, apontado como uma das causas de acidentes do trabalho, na Norma Brasileira 18, Cadastro de acidentes (Associação Brasileira de Normas Técnicas 1975):

c) A pessoa que o pratica pode fazê-lo consciente ou não de estar agindo inseguramente. 
e) $O$ ato inseguro não significa, necessariamente, desobediência a normas ou regras constantes de regulamentos formalmente adotados, mas também se caracteriza pela não observância de práticas de segurança tacitamente aceitas. Na sua caracterização cabe a seguinte pergunta: nas mesmas circunstâncias, teria agido de mesmo modo uma pessoa prudente e experiente? (p. 19)

Considera-se que, de acordo com a voluntariedade da ação, ocorre dolo ou culpa. No primeiro caso, dito de culpa in re, a situação em que ocorre o dano é pretendida e, no segundo, dito de culpa in causa, o perigo não é desejado, e até se desejaria que não ocorresse, embora pudesse ser previsto. A necessidade de provar a existência dessa voluntariedade imputável ao agente do dano é primacial na concepção clássica de culpa e enseja a defesa de existência de componente subjetivo nessa concepção.

Segundo Lima (1998b), para o entendimento da responsabilidade em caso de acidentes, é importante distinguir se a lesão ou dano "resulta do fato imediato de outra pessoa ou decorre do fato da coisa" (p. 46). Um dos exemplos dessa última é a culpa na guarda, que decorre do fato de o homem ser "obrigado à guarda das coisas, de modo a ter o controle absoluto das mesmas [...]", impedindo que provoquem dano a outrem. No direito francês, a responsabilidade do fato da coisa foi aplicada a grande número de acidentes, incluindo aqueles de automóveis, de caça, de esportes, de explosões de máquinas, causando danos a terceiros (p. 85). Ficam excetuadas as hipóteses de força maior, caso fortuito ou culpa da vítima (p.87).

Na opinião de Lima (1998c), essas aplicações mostram, "de modo inequívoco, o deslocamento da aplicação da culpa cometida por fatos incontestavelmente pessoais para a culpa decorrente do fato das coisas [...] como resultado inelutável das grandes e profundas transformações de ordem econômica e social [...]. É uma reação à insuficiência da teoria da culpa clássica [...]”. A culpa é considerada "resquício da confusão primitiva entre responsabilidade civil e penal", e sua identificação associa-se não à noção de reparação do dano, e, sim, à de infligir uma pena ao autor do prejuízo causado (p. 116).

Deixando de lado a necessidade de comprovação do elemento moral subjetivo e da imputabilidade moral, característica da noção de culpa, cresce a aceitação da 
teoria objetiva da responsabilidade, que parte do reconhecimento de que o progresso econômico-social cria insegurança material da vítima em situação de "desigualdade [...] entre os criadores do risco e aqueles que suportam os efeitos nocivos destes perigos" (Lima 1998d). Acresce “a criação cada vez mais acentuada da impossibilidade de provar a causa" dos acidentes ou a culpa de seus responsáveis ( $p$. $331)$.

De acordo com Carvalho e Segre (1977), no Brasil, a legislação acidentária baseia-se na doutrina do risco profissional, ou seja, na aceitação da idéia de que o "trabalho estabelece [...] um risco próprio que lhe é imanente". A noção de risco profissional difere do risco criado ou da culpa objetiva porque torna desnecessário o ônus da prova ao empregado.

Segundo Cohn e col. (1985), a Lei Brasileira de Acidentes do Trabalho, de 1976, sustentava-se na doutrina do risco social, que "garante a assistência social mínima ao acidentado, qualquer que seja a causa, mas ela se torna perversa à medida que dissolve o dever do empregador em reparar os danos resultantes da violação do direito [...] do indivíduo".

Brandimiller (1996, p. 262) especifica: “A responsabilidade do empregador pelo acidente do trabalho ou doença profissional é subjetiva, decorrente de culpa no

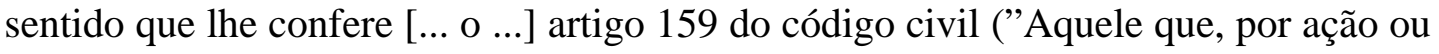
omissão voluntária, negligência ou imprudência, violar direito, ou causar prejuízo a outrem, fica obrigado a reparar o dano")".

Por sua vez, o Seguro Obrigatório de Acidentes do trabalho, cujo custeio cabe apenas ao empregador, baseia-se em situação análoga à responsabilidade objetiva, mas não nesta. De acordo com a culpa objetiva, "quem tira proveito de uma situação em contrapartida responde pelos riscos ou desvantagens dela decorrentes". No caso desse Seguro, o acidente do trabalho foi considerado "como risco profissional e mais modernamente como risco social: o dano pessoal (dele) decorrente [...] gera um estado de necessidade que deve ser compensado de forma imediata, 
independentemente da capacidade de pagar do empregador e da distribuição de culpa" (Brandimiller 1996, p 262-263).

Lima (1998d) destaca que, em nosso país, historicamente, as leis de acidentes do trabalho consagraram o princípio da responsabilidade objetiva do patrão, "excetuando o dolo da vítima, ou de terceiros ou os casos de força maior, por fatos estranhos ao trabalho".

Em síntese, a "doutrina do risco criado [...] faz derivar a responsabilidade do fato humano, como produto das atividades em choque, criadoras de riscos, a fim de restabelecer o equilíbrio dos patrimônios" (Lima 1998d. p. 332).

Em publicação patrocinada pela Association des Industriels de France, François e col. (1985) reconhecem que a palavra responsabilidade se associa a conotação negativa de culpa e de punição, mas defendem sua fixação. Os autores lembram que, na legislação francesa, até 1976, a responsabilidade era do chefe da empresa, exceto se este pudesse provar que havia delegado sua autoridade a um de seus subordinados. A partir de 1976 a legislação passa a considerar mais nitidamente a falta pessoal do empregador, que deveria ser identificada de modo mais preciso ao descumprimento de regras.

Kouabenan (1999a) destaca que, enquanto na inferência causal "trata-se de provar a existência de uma ligação entre uma causa suposta e um efeito", na atribuição de responsabilidade "trata-se de ir além da simples ligação para designar o autor presumido de um evento. [...] trata-se de identificar um culpado".

A noção de responsabilidade supõe uma intervenção causal interna (humana) e controlável pelo agente em questão. Tentando definir as relações entre causalidade, intencionalidade e responsabilidade, Heider $^{5}$ propôs 5 níveis de responsabilidade: 1) a associação - em que medida o ator está associado ao evento? 2) a comissão - em que medida o ator teria papel instrumental ou causal, mesmo que sem poder tê-lo previsto? 3) a previsibilidade - em que medida poderia prever o efeito, mesmo sem

\footnotetext{
${ }^{5}$ Apud Kouabenan (1999a)
} 
ter a intenção de produzi-lo? 4) a intencionalidade - até que ponto o ator teria procurado intencionalmente os efeitos que ele poderia prever? 5) a justificativa - em que medida o comportamento visado, incluídas suas motivações, seria justificável pelas mudanças do ambiente? (Kouabenan 1999 a, p. 37).

Procurando contornar a ambigüidade e imprecisão da noção de responsabilidade, Fishbein e Ajzen ${ }^{6}$ apoiam-se na proposição de Heider e afirmam que "perguntar-se acerca da responsabilidade de um indivíduo em um acidente, é colocar-se diante de uma variedade de questões tais quais: o indivíduo está associado ao acidente? Teve qualquer papel instrumental no acidente, no sentido de que poderia tê-lo causado? Poderia ter previsto sua ocorrência? Teve a intenção de causá-lo? Em que medida seu comportamento seria ou não passível de justificativa?" (Kouabenan 1999a). A responsabilidade aumenta com a passagem dos níveis 1 a 5.

A caracterização de responsabilidade é mais complexa que a de causa. Os fatores causais considerados não controláveis, moralmente condenáveis ou socialmente indesejáveis parecem determinantes na atribuição de responsabilidade.

Se o objetivo do observador for determinar responsabilidades, a explicação causal dirige-se às pessoas direta e ativamente implicadas no desencadeamento dos eventos "anormais", na persistência de fatores que representem descumprimento de regras, etc. A "regra de parada" da análise vai consistir na identificação de uma pessoa que tenha cometido um erro em situação em que tenha controle de seus atos. Nesse caso, a contigüidade temporal entre o ato e os danos causados também parece influenciar as atribuições de causa, de negligência do ator e de responsabilidade. Nas palavras de Kouabenan (1999 a),

"Quando a análise é orientada para a atribuição de responsabilidade, a imputação é interrompida com a descoberta e a sanção de um responsável".

\footnotetext{
${ }^{6}$ Idem nota anterior.
} 
A familiaridade do investigador com os eventos e atos identificados na rede explicativa do acidente também é apontada como associada com a interrupção da investigação causal.

Quanto maior a cadeia causal, quanto mais se investiguem as "causas das causas", maior a chance de se encontrarem causas externas do acidente e de que este seja concebido como complexo.

Sendo a regra de parada da investigação a identificação das "causas fundamentais" do acidente ou de "elementos sobre os quais se possa agir para melhorar a confiabilidade do sistema", torna-se importante traduzir esses fatores causais em alvos operacionais para a intervenção preventiva. Wagenaar e Reason (1990) estão entre os autores que preconizam como mais eficaz, na prevenção de acidentes, a supressão das "type causes", causas profundas, remotas ou tardias, que aparecem mais à esquerda, numa árvore de causas, ou em esquemas do acidente, do que a ação sobre as "token causes", causas diretas que precedem mais diretamente as conseqüências do acidente.

"Remédios podem ser propostos em cada estágio na seqüência causal mas é nossa opinião que eles serão mais efetivos quando nós os propusermos nos estágios mais precoces."

Almeida e col. (2000) também afirmam que, ao suprimir a busca dessas causas, a investigação volta-se para identificação de responsáveis, inibindo a prevenção de acidentes.

Do exposto, verifica-se a conformação de problema de estudo relativo às formas de escolha, conscientes ou não, explícitas ou não, de uma "regra de parada" da investigação causal de acidentes e à introdução ou não de busca de definição de responsável por essa ocorrência. O desenvolvimento de estudos acerca de investigações de acidentes, no âmbito de empresas, pode identificar aspectos que esclareçam formas de escolha de "regras de parada" da investigação e de definição de responsável pelo acidente. 


\subsection{Atribuição de causa e responsabilidade na psicologia}

Segundo Janoff - Bulman (1982), a auto-acusação é uma resposta comum e bem documentada em vítimas de violência, como, por exemplo, estupro. Segundo o autor, há dois tipos de auto-acusação:

- O comportamental, em que a pessoa culpa algum comportamento que adotou e que não deveria ter adotado, e

- O ligado ao caráter ("characterological”), em que a culpa é atribuída a uma "falha" ou "imperfeição" do caráter da vítima.

A auto-acusação ligada ao caráter representaria autodepreciação e baixa autoavaliação (autoevaluation), enquanto a comportamental representaria tentativa de restabelecer o controle pela vitimização. Ou seja, citando o comportamento que poderia ser evitado no futuro, a vítima de estupro poderia manter a crença na evitabilidade de estupros futuros, ou na sua capacidade de controlar os resultados.

A redução da vulnerabilidade percebida seria central para a compreensão do papel adaptativo proposto para vítimas que se auto-acusam de modo comportamental e seria implícita em explicações da "Just World teoria". As pessoas teriam necessidade de acreditar em um "Just World", para ter a sensação de confiança e esperança no futuro. Essa sensação seria ameaçada pela condição de vítima, tanto nas vítimas quanto nos observadores. A auto-acusação seria adaptativa na medida em que contribuísse para a redução da vulnerabilidade percebida.

No caso de observadores de situações de estupro, os dois tipos de autoacusação contribuiriam para a sensação de confiança no futuro.

As vítimas seriam capazes de sentir-se relativamente invulneráveis, quando engajadas em auto-acusação comportamental e não relacionada ao caráter. Para observadores, a crença na invulnerabilidade seria auxiliada pelos 2 tipos de autoacusação. 
Estudando observadores de vítimas de estupro, Karuza e Carey (1984) concluíram que apenas a culpa comportamental exerceria papel de adaptação para observadores, ajudando a manter a crença de que o mundo é um local controlável e com sentido. Para os autores, o fato de esse achado referir-se a casos em que todas as vítimas são mulheres de um tipo específico de violência deve ser considerado e, por isso mesmo, a possibilidade de generalização dos achados deveria ser tratada como questão que requer novos estudos.

Kouabenan (1985) conclui que a atribuição causal é influenciada pelo nível hierárquico do atribuidor (empregado ou chefia), pela satisfação no trabalho (satisfeito ou insatisfeito), pelo grau de implicação do atribuidor no AT (testemunha ou vítima) e pela gravidade das consequiências ou lesão. Ao atribuir causa, viriam à tona vieses defensivos ou de defesa da auto-estima.

Segundo Brewer (1977), muitos dos resultados em que a atribuição de responsabilidade é explicada como relacionada a "tendências irracionais", como estratégia defensiva ou a necessidade de acreditar num mundo justo ("just world"), seriam inconsistentes e poderiam ser reavaliados em termos de análise do processamento de informações não motivacional ("nonmotivational information processing analysis"). De acordo com o modelo proposto por esse autor, em essência, a "atribuição de responsabilidade é [...] um julgamento do grau em que o resultado de algum incidente foi determinado ou influenciado por um ato perpetrado por algum indivíduo”. Esse julgamento seria influenciado por dois componentes independentes:

- A expectativa anterior, ou seja, a probabilidade subjetiva de que o resultado teria ocorrido, dadas as condições anteriores ou o curso natural do evento, na ausência do comportamento perpetrado. $\mathrm{O}$ valor dessa expectativa é considerado inversamente proporcional à atribuição de responsabilidade: quanto maior a expectativa do resultado, na ausência do comportamento, menor seria a atribuição de responsabilidade a quem perpetra o comportamento. 
- A congruência, ou seja, a probabilidade subjetiva de que o resultado seria esperado, dada a ação perpetrada por alguém. $O$ valor da congruência é considerado diretamente proporcional à atribuição de responsabilidade.

Para Brewer (1977), o fato de os efeitos das características do resultado, da vítima e do perpetrador sobre a atribuição de responsabilidade poderem ser explicados pela análise do processamento de informações não motivacional não significa que motivações e necessidades não sejam relevantes na atribuição de responsabilidade. Ao contrário, estes fatores poderiam influenciar, ou "enviesar" a estimativa subjetiva da congruência e da expectativa anterior. Um dos exemplos destacados pela autora é o de que, na ausência de referência explícita a contingências ou fatores causais externos ao indivíduo, atribui-se maior importância a causas únicas internas como determinantes isolados das conseqüências de um acidente.

Para Tversky e Kahneman (1974), as crenças acerca da probabilidade de eventos incertos baseiam-se em número limitado de processos heurísticos, simplificando a complexidade da avaliação, transformada em operações de julgamentos. Embora úteis, esses procedimentos levariam a erros previsíveis e sistemáticos.

A seguir, apresenta-se breve histórico da atribuição de causa na literatura de acidentes. Logo depois, citam-se, com breve descrição, formas de investigação recomendadas e, por fim, aspectos da prevenção de acidentes ou de medidas de prevenção recomendadas a partir de análises realizadas em chão de fábrica. Ao longo de todo o processo, priorizam-se as práticas mais difundidas no país e/ou nas empresas estudadas no município.

\subsection{Atribuição de causa e culpa na literatura de investigações de acidentes}

Segundo Haddon Jr (1968), a visão que considera doenças e acidentes como formas de expiação de pecados associa-se à persistência de noções que atribuem os 
acidentes à "sorte", "acaso" ou outras explicações não racionais. Segundo este autor, a superação dessas noções exige a adoção de abordagens etiológicas dos acidentes.

Em 1978, Wigglesworth afirma que a culpa lançada sobre as vítimas dos acidentes associa-se com o desenvolvimento histórico das noções de comportamento faltoso e negligente, nas legislações de indenização de vítimas e de intervenção nos ambientes de trabalho. Na opinião deste autor, estabelece-se confusão entre alocação de culpa e identificação de causa, com ênfase em aspectos do comportamento humano e exclusão dos demais fatores, com consequiências negativas para a prevenção.

Em 1981, Booth lamenta que pesquisadores persigam a causalidade em termos comportamentais estritos, com ênfase em circunstâncias que antecedem imediatamente ao acidente. O autor revisa abordagens adotadas na prevenção de acidentes, destacando a grande difusão daquelas que atribuem os acidentes a "falhas humanas", e lembra a influência de Heinrich, pai da teoria do dominó, que, em seu livro, publicado pela primeira vez em 1931, afirmava que $90 \%$ dos acidentes eram causados por atos inseguros dos trabalhadores. Criticando essa abordagem, ele destaca que, em 1972, Hale e Hale já tinham mostrado que a eficácia das medidas preventivas recebia pouca atenção e cita Kletz, que, em 1979, afirmava “... dizer 'Acidentes são causados por falhas humanas' não é inverdade, mas não é muito útil. Isso nos encoraja a dizer às pessoas para terem mais cuidado, ao invés de procurar modos de reduzir as oportunidades de erro".

A atribuição de culpa ao trabalhador pela ocorrência do acidente que o vitimou teve na Teoria da Propensão ao Acidente um de seus pilares de sustentação. Em 1981, Saas e Cook discutiram equívocos estatísticos presentes em estudos dos primeiros defensores dessa teoria e apontaram seu papel como mais uma tática de atribuição de culpa à vítima.

Depois de afirmar que cerca de $70 \%$ dos acidentes de aviação têm sido atribuídos a erros humanos, Feggetter (1982) acrescenta que, no passado, 
freqüentemente, o investigador se satisfazia com uma descrição superficial de falha, ao invés de buscar explicação em termos de causas e mecanismos dessas falhas.

Segundo Leplat (1983), a mentalidade moderna ainda está impregnada com a concepção fatalista de acidentes ilustrada em frases como "a hora dele chegou". Depois de comentar que essa concepção tem sido apontada como mais presente entre pessoas com nível de instrução mais baixo, Koubenan (1999a) destaca achado de estudo conduzido por ele, em que, ao referir-se aos acidentes em que estiveram implicados, independentemente de seu "status" social, os entrevistados não hesitam em afirmar que tiveram um pouco de azar ("malchance").

Szasz (1984), reconstruindo o que denomina trajetória de um conceito ideológico - o da propensão ao acidente -, chama a atenção para dois aspectos que considera favoráveis à difusão dessa teoria: o econômico, representado pelo interesse de gerentes na contenção de custos de compensação aos acidentados, e o corporativo, representado pelo interesse de psicólogos industriais, categoria profissional emergente, responsável pela elaboração dessa teoria que, apesar de inúmeras tentativas, nunca chegou a ser cientificamente comprovada (grifos nossos).

Na década de 50, a Teoria da Propensão ao Acidente começa a ser desacreditada, tendo sido os engenheiros os primeiros a abandoná-la, procurando explicações mais satisfatórias para a ocorrência dos acidentes. Posteriormente, esses profissionais foram seguidos pelos psicólogos industriais. Apenas entre os psicólogos ligados à tradição analítica, em sua maioria afastados da realidade do interior da fábrica, essa teoria continuou encontrando alguma aceitação (Szasz 1984).

Em 1984, Perrow comenta que é preciso examinar minuciosamente a tese que afirma ser o erro humano a causa mais importante do acidente, pois ela "oculta mais coisas do que explica". Para Perrow, "As políticas de empresa, a concepção das plantas e do equipamento e as pressões comerciais contribuem todas elas para o erro dos operadores. [...] Poderíamos concluir, afirmando que o erro dos operadores foi não terem sido capazes de superar completamente o caráter complexo e inadequado do equipamento que deveriam utilizar". 
Em 1986, Allegrante e Sloan denunciam a prática de atribuir a culpa do mal à sua vítima como um dos dilemas éticos em saúde ocupacional. Segundo esses autores, como resultado dessa falha dirigem-se "todos os esforços para a mudança do comportamento da vítima mais do que das circunstâncias responsáveis pelo problema”.

Estudando a atribuição causal e a seleção de medidas corretivas, por parte de supervisores, em acidentes com múltiplas causas, Dejoy (1985) evidenciou que: a) a existência de causa antecedente de mesmo tipo da imediata acresceria pouca informação àquela fornecida pela causa imediata; b) a existência de causa antecedente oposta à causa imediata só revertia os efeitos desta, quando esta causa antecedente era interna ao trabalhador; c) embora as causas imediatas fossem percebidas como mais importantes que as antecedentes, a posição temporal da causa era menos importante que a sua condição de interna ou externa ao acidentado. $\mathrm{Na}$ opinião do autor, aqueles colocados na posição de supervisores mostram maior probabilidade de centrar-se em causas internas, quando confrontados por informações causais conflitantes.

Descuido, desatenção, negligência, dentre outras, são expressões que descrevem o acidente de forma subjetiva, em termos de "falta" de pessoa ou pessoas, dificultando sua reconstrução em termos factuais. Sua utilização refletiria meramente a predisposição dos responsáveis pela coleta de dados ou a busca "a priori" de causa única do acidente, ligada ao indivíduo, configurando investigações tendenciosas (Wigglesworth 1978; Waller 1987). Nessas situações, os acidentes são descritos em termos normativos e investigados sem realização de análise da tarefa, do sistema homem-máquina e do contexto sócio-político da empresa.

Depois de criticar a Teoria da Propensão ao Acidente, Hoyos e Zimolong (1988) afirmam que o acidente resulta de seqüência de eventos representados por interação entre fatores técnicos e comportamentais. Para eles, o estabelecimento de dicotomia entre esses fatores, nas investigações de acidentes, seria inadequado. 
Em 1991, Feyer e Willianson destacam que, de modo geral, as investigações de acidentes não levam em consideração a multiplicidade de fatores causais, nem analisam as eventuais relações existentes entre eles.

Estudo conduzido por Kouabenan (1998) mostra que as crenças e as práticas sociais influenciam tanto a percepção de risco quanto as explicações das pessoas acerca das causas de acidentes. As pessoas consideradas fatalistas teriam conhecimentos limitados acerca de riscos e acidentes. Eles seriam distinguidos por atribuição causal que expressa falta de controle sobre os eventos. No estudo do autor, os acidentes de trânsito são atribuídos a fatores causais externos ao controle dos motoristas, e menor importância é dada aos fatores que implicam iniciativas de sua responsabilidade. Essa racionalização tenderia a minimizar a responsabilidade do indivíduo pelo acidente e, como conseqüência, também a sua culpa, funcionando como um mecanismo de defesa.

Segundo o Canadian Center for Occupational Health \& Safety (CCOHS 1998), raramente, ou nunca, um acidente teria apenas uma causa. Se, num acidente aparentemente simples, conclui-se que a causa foi um descuido do trabalhador e não se vai adiante, deixa-se de buscar respostas a perguntas importantes, como:

- O trabalhador estava distraído? Se sim, por quê?

- O procedimento que estava sendo seguido era seguro? Se não, por quê?

- Os equipamentos de segurança estavam em ordem ou disponíveis? Se não, por quê?

- O trabalhador era treinado? Se não, por quê?

Uma investigação que responda a essas e outras questões afins, provavelmente, revela condições mais importantes para a correção do que tentativas de prevenir o "descuido". Mais adiante, após lembrar que muitos modelos têm sido propostos para explicar as causas de acidente, propõe-se modelo simplificado de 
busca de causas ligadas a 5 categorias: tarefa, material, ambiente, pessoal e gerencial (CCOHS 1998).

A lista de autores que constatam a predominância, na literatura, de investigações baseadas em concepção paucicausal ou monocausal de acidente, com frequiência resumida à falha humana ou a uma só categoria geral, mais extensa - os fatores comportamentais - poderia estender-se longamente. Tais investigações centram-se no estudo dos chamados fatores imediatamente precipitadores dos acidentes - FIPA, também denominados fatores imediatamente antecedentes dos acidentes - FIAA, não investigando as condições do sistema que permitem a sua origem.

\subsection{Influências das concepções de causa, culpa e responsabilidade, na investigação de acidentes do trabalho, no Brasil}

As propostas de investigações de acidentes mais difundidas no Brasil têm suas origens nas idéias de Heinrich (1959), divulgadas, inicialmente, na década de 30. Segundo ele, o acidente seria resultante de seqüência linear de eventos, apresentada como equivalente a 5 peças de dominó, dispostas segundo ordem "fixa e lógica". A terceira peça introduziu a dicotomia atos inseguros/condições inseguras. A partir daquela data, surgem inúmeras propostas de investigação de acidentes, porém, segundo Monteau e Pham (1988), a concepção de Heinrich facilitou a ação, e, por isso mesmo, os métodos de análise de acidentes dela derivados alcançaram grande desenvolvimento entre os investigadores desses eventos.

No Brasil, o Ministério do Trabalho e Emprego, através de emissão de Normas Regulamentadoras (NR 4 - Serviço Especializado em Engenharia de Segurança e em Medicina do Trabalho - Sesmt -; NR 5 - Comissão Interna de Prevenção de Acidentes - CIPA -; e NR 18 - Condições e Meio Ambiente de Trabalho na Indústria da Construção), torna obrigatória a investigação de acidentes do trabalho com uso de dois instrumentos de coleta de informações: o formulário de análises de acidentes (Anexo 2 da NR 5) e a ficha de acidente do trabalho 
(Anexo 1 da NR 18), esta última para uso específico em casos de acidentes ocorridos com trabalhadores da construção civil (Brasil 1998).

Até fevereiro de $1999^{7}$, o Anexo 2 da NR 5 incluía proposta padronizada de realização de investigações de acidentes do trabalho com base em concepção paucicausal e dicotômica - fatores técnicos/fatores humanos ou condições inseguras/atos inseguros -, segundo modelo que exigia a identificação de responsável pela ocorrência do acidente, sendo a conclusão acerca de causa do acidente registrada no singular, ou seja, como se o acidente fosse unicausal.

De acordo com o Anexo III da Norma Regulamentadora número 5 da Portaria 3214 do Ministério do Trabalho (Brasil 1998), as causas dos acidentes do trabalho seriam atos inseguros/condições inseguras, e a investigação de acidentes é apresentada como:

"procura das causas do acidente; fonte de lesão; fator pessoal de insegurança; natureza da lesão; localização da lesão".

Essa Norma não explicitava os conceitos que adotava para os elementos citados, porém, de acordo com a Associação Brasileira de Normas Técnicas - ABNT - (1975), esses elementos são descritos como se segue:

- "ato inseguro" é o ato que, contrariando preceito de segurança, pode causar ou favorecer a ocorrência do acidente;

- "condição ambiente de insegurança ou condição ambiente" é a condição de meio que causou o acidente ou contribuiu para sua ocorrência;

- "fonte da lesão" é a coisa, substância, energia ou movimento do corpo que diretamente provocou a lesão;

- "fator pessoal de insegurança ou fator pessoal" é a causa relativa ao comportamento humano que leva à prática do ato inseguro; 
- "natureza da lesão" é a expressão que identifica a lesão, ou seja, qualquer dano sofrido pelo organismo humano como conseqüência de acidente do trabalho, segundo suas características principais;

- "localização da lesão" é a indicação da sede da lesão.

Baumecker (2000a) analisou de modo detalhado a Nbr 18 e sua nova versão, Nbr 14280, criticando o processo de alteração da primeira, sem participação da sociedade, e o fato de a segunda (Nbr 14280) manter concepção de causalidade de acidentes centrada na idéia de erro humano ou falha dos operadores. Entre outros aspectos, a autora destaca:

"A norma possibilita incluir qualquer ato como "inseguro" e como em qualquer acidente há um ato, abriu-se um hiato onde cabem todas as ocorrências” (Baumecker 2000a, p. 26).

"Morte, para a Nbr 14280, é a "cessação da capacidade para o trabalho pela perda da vida” [...] O problema é a perda da “capacidade para o trabalho” [...] Ou seja, o importante é produzir e não viver” (Baumecker 2000 a, p. 27).

“[...] a norma tem vários termos e definições confusos” (Baumecker 2000 a, p. 33).

Também merece registro o fato de que a "ficha de comunicação e investigação de acidentes" e a "ficha de comunicação de acidentado", incluídas no apêndice 4 da Nbr 18, revisada em 1999, resultando na Nbr 14280, da ABNT, não incluem campo destinado ao registro de responsável pelo acidente.

A legislação brasileira - NR 4, NR 5, NR 7, NR 9, NR 18 ... - estabelece a obrigatoriedade de elaboração de estatísticas de acidentes e recomenda sua utilização na definição de prioridades e metas a serem adotadas pelas empresas, assim como estabelece a realização de inspeções de segurança que devem identificar fatores e situações de risco e solicitar as correções devidas com vistas à prevenção desses fenômenos (Brasil 1998).

7 A Portaria SSST / MTE, no 08, de 23 de fevereiro de 1999, alterou a Norma Regulamentadora 5. 
De acordo com a legislação citada, concluída a análise de acidente pela CIPA, esta encaminha seu resultado, com recomendações de correções a serem adotadas, ao empregador, que, tendo ouvido o Sesmt, responde em até 8 dias. Havendo discordância em relação às medidas preconizadas pela CIPA, se esta não aceitar a justificativa apresentada pelo empregador, a representação do Ministério do Trabalho é convocada para encaminhar tentativa de solução para a questão.

No caso brasileiro, inexistem, na legislação e na norma ABNT citadas, explicações relativas à maneira de preenchimento do campo "responsabilidade", presente na "ficha de análise de acidentes", Anexo II da NR 5. Cabe, portanto, ao investigador definir, através de seu próprio julgamento, resposta à questão, eivada de subjetividade e complexidade, tendo como base apenas investigação realizada com instrumento que a direciona para abordagem simplista e unicausal.

A adoção de formulário de investigação de acidente com campo destinado à definição de responsável pela ocorrência parece ter como propósito preocupação de natureza jurídica, e não técnica, de comprovar ou atribuir culpa à vítima e, conseqüentemente, atribuir-lhe a responsabilidade pelo ocorrido, eliminando ou dificultando as chances de responsabilização civil e penal do empregador. Conduzida a investigação pela CIPA, organismo de composição paritária e assistido por profissionais especializados em prevenção, a conclusão ganha "status" de decisão técnica competente.

Do ponto de vista da prevenção de acidentes, não parece, portanto, haver justificativa para a definição de responsabilidade por sua ocorrência.

Cohn e col. (1985) utilizaram a expressão "produção da consciência culposa" para descrever a forma como foi sendo produzida concepção que culmina em atribuição quase sistemática de culpa ao acidentado. Destacam a importância do papel do Ministério do Trabalho, através de sua instituição de pesquisa, a Fundacentro, bem como de organismos privados patronais nesse processo, por meio de publicações, vídeos, filmes, campanhas e cursos que explicam os acidentes através 
da concepção dicotômica fatores técnicos/fatores humanos, com predomínio dos últimos. Os autores concluem:

"De vítima a réu no processo de trabalho, de vítima a agente do acidente do trabalho, o trabalhador apesar de não ter nenhum controle sobre a organização e o processo de trabalho, [...] deve, necessariamente, administrar as condições adversas do trabalho, no sentido de evitar o acidente, caso contrário corre o risco de ser acusado de ter inclusive praticado um ato de automutilação” (p.149).

Analisando a segurança no trabalho rural, Garcia (1996) denomina de simplista o enfoque que "reduz a complexa questão que envolve a utilização dos agrotóxicos e suas conseqüências danosas à saúde e ao meio ambiente a um ‘problema de educação’ daqueles que os utilizam” (p.197).

Em numerosos textos brasileiros sobre investigação de acidentes (Serviço Social da Indústria 1967; Associação Brasileira de Normas Técnicas 1975; Mccullough 1973; Mielnik 1976; Ribeiro Filho 1981; Zocchio 1980; Oushiro 1980; Brasil 1980, 1981, 1983; Clemente 1981; Saad 1981; Camargo 1988), constata-se ausência de menção à necessidade e importância da análise da tarefa realizada pelo acidentado, quando da ocorrência do acidente. Tais textos não orientam a reconstrução dos fatos e a observação do cenário em que o acidente ocorreu, nem tampouco formas de sistematizar a coleta de informações, imprescindíveis à identificação dos fatores causais desses fenômenos.

Revendo a apresentação dessa concepção, na literatura brasileira, Almeida (1996) descreve:

“... encontram-se definições de atos inseguros caracterizadas por elevado grau de subjetividade como, por exemplo: "maneira como as pessoas se expõem, consciente ou inconscientemente, a riscos de acidentes", "aquele que o trabalhador faz sem observar certas regras de segurança”, "causas que residem exclusivamente no fator humano" (Serviço Social da Indústria 1967; Associação Brasileira de Normas Técnicas 1975; Mccullough 1973; Mielnik 1976; Ribeiro Filho 1981; Zocchio 1980; Oushiro 1980; Brasil 1980, 1981, 1983; Clemente 1981; Saad 1981; Camargo 1988). Para Clemente (1981), fatores pessoais de insegurança, enquanto causas remotas de atos inseguros, não 
apresentam interesse: 'podemos deles prescindir, concentrando nossa atenção em suas consequiências: os atos inseguros"” (grifos nossos).

Em sua revisão, Almeida (1996) destaca publicação da Fundacentro, órgão do Ministério do Trabalho (Clemente 1981), em que se aponta a inadaptação entre homem e função como causa de atos inseguros desencadeadores de acidentes e se afirma que a mesma pode decorrer de:

"a) fatores constitucionais: - sexo, idade, tempo de reação aos estímulos, coordenação motora, estabilidade, instabilidade emocional... nível de inteligência, grau de atenção, percepção, coordenação visomotora;

b) fatores circunstanciais: problemas familiares, abalos emocionais... grandes preocupações".

A seguir, exemplificando desajustes individuais capazes de desencadear acidentes, há descrições de casos, como "do desleixado", "do machão", "do exibicionista calado e do falador", "do desatento" e "do brincalhão". Em relação aos dois grupos de fatores citados, não há referência a técnicas, critérios ou cuidados necessários à sua avaliação, deixada ao arbítrio de cada investigador.

Face a afirmações desse tipo, pode-se supor que, no Brasil, a difusão e apropriação das propostas de Heinrich parece ter ocorrido em moldes que acarretaram sua redução acrítica à terceira pedra, ou seja, a que introduz a noção de atos e condições inseguros (AI/CI). Monteau e Pham (1988) indicaram, com muita propriedade, que, se esses dois componentes - AI/CI - forem isolados, ficam sem um quadro de referência que possibilite a análise coerente de sua participação nos acidentes. Além disso, essa descontextualização pode facilitar a aceitação da opinião de que o acidente se deve exclusivamente a "causas" internas ao acidentado.

Binder e col. (1997) mostraram que, em 70\% de acidentes investigados em 3 empresas metalúrgicas de grande porte e possuidoras de Sesmt do Estado de São Paulo, considerou-se como "causa" a prática de ato inseguro pelo acidentado ou colega de trabalho e que, em $83 \%$ dos casos, o acidentado foi considerado 
responsável pela ocorrência. Os autores também evidenciaram que, em 38\% dos registros, a "causa apurada" com utilização do modelo de investigação padronizado pelo Ministério do Trabalho incluía termos ou expressões, como "descuido, negligência, desatenção, exposição desnecessária ao perigo", além do registro de causas como "operação incorreta" (15\%), "improvisação" (2,8\%), "pressa na execução da tarefa" $(2,1 \%)$, que foram interpretados como reveladores de emissão de juízo de valor ou julgamento "a priori" atribuidor de causa do AT a comportamentos faltosos do próprio acidentado.

Situações ilustrativas do que Wigglesworth (1978) denomina limitações das capacidades fisiológicas ou natureza finita das capacidades humanas são apresentadas como fatores individuais "inadequados", desconsiderando-se que, no desenvolvimento de suas atividades, o indivíduo interage com os recursos que lhe são oferecidos e com matérias-primas, em ambiente e organização do trabalho que lhe são impostos, e em que os estímulos que recebe podem aproximar-se dos limites de suas capacidades fisiológicas - ou mesmo ultrapassá-los -, seja em condições de funcionamento habitual da empresa, seja na vigência de mudanças em qualquer dos seus componentes.

Oliveira F (1997, p. v) constatou "a presença marcante nos modos comuns de compreensão dos acidentes da Teoria do Dominó de Heirinch e a predominância das explicações calcadas nos atos inseguros, sustentadas pela naturalização dos riscos”.

Os achados dos estudos de Binder e col. (1997) e de Oliveira (1997) sugerem que, no interior de empresas, no grupo de trabalhadores que conduzem investigações de acidentes (membros de CIPA, engenheiros e/ou técnicos de segurança), a atribuição de culpa poderia ser comparada a fenômeno de "institucionalização", ou seja, influenciada pela ação de organismos oficiais, o Ministério do Trabalho e a Fundacentro, além da ação de agências patronais que desenvolveram atividades relacionadas com a formação de recursos humanos e divulgação de material instrucional voltado para o atendimento de exigências introduzidas pelo Ministério do Trabalho. 
Segundo Binder e col. (1997) "o formulário utilizado, ao assinalar, no singular, "causa apurada" e "causa do acidente", induz a investigações sumárias, incapazes de pôr em evidência o conjunto de fatores provavelmente envolvidos na gênese desses fenômenos, com prejuízos para a prevenção".

Vale acrescentar que, apesar de as investigações citadas serem registradas em formulário a ser preenchido por membros da CIPA, em se tratando de empresa possuidora de Sesmt, é a este que cabe, na prática, a primazia da investigação, a ser registrada em formulário específico. Neste caso, cabe à CIPA: "investigar ou participar, com o Sesmt, da investigação de causas, circunstâncias e consequiências dos acidentes ...” (5.16.h, NR- 5).

Quem é, nesses casos, o responsável pelas respostas aos quesitos do formulário? Em nossa experiência, a resposta a esta questão tem sido bastante heterogênea. Temos visto empresas em que membro da CIPA acompanha técnico do Sesmt, durante investigação em que se preenche seu formulário específico que, posteriormente, é usado para preenchimento, por secretária da CIPA ou do Sesmt, do anexo obrigatório para essa comissão. Em outros casos, o técnico responsável pela investigação usa o mesmo formulário definido para a CIPA ou preenche formulário específico definido pelo Sesmt, encaminhando-o para a CIPA, em substituição ao anexo II da NR 5. Em empresas onde há predomínio de empregados com baixa escolaridade, temos visto o preenchimento dos anexos ser deixado a cabo de profissional integrante da administração, membro ou não da CIPA, e, em outros casos, o preenchimento do formulário é feito por membro da CIPA ou por secretária dessa comissão. Mais recentemente, empresas que não possuem CIPA, passaram a contratar serviços de assessorias específicas que se responsabilizam pelo preenchimento dos formulários definidos na legislação como obrigatórios.

Como a formação dos responsáveis por esse preenchimento contempla os aspectos relativos à investigação de acidentes e preenchimento desses formulários? De acordo com nossa experiência, em muitos casos, trata-se apenas de treinamento de CIPA, curso que tem carga horária mínima de 18 horas para abordagem que contemple, no mínimo, os 11 itens listados no seu currículo básico. Nas empresas 
com Sesmt, a condução da investigação cabe, em geral, a técnico de segurança e pode contar, eventualmente, com interveniência de engenheiro de segurança. A formação desses profissionais pode incluir acesso a outras fontes de informação e orientações acerca da condução de investigações de acidentes, parte das quais pode vir a ser divulgada na empresa através de materiais educativos, frases de segurança, matérias em boletins ou jornais da empresa, etc.

\subsection{Algumas dificuldades apontadas na investigação de acidentes}

Benner Jr (1985), estudando 17 metodologias e 14 modelos de investigação de acidentes que identificou em estudo realizado junto a 17 agências governamentais selecionadas, evidencia a ausência quase completa de critérios objetivos de controle da qualidade de investigações de acidentes e, particularmente, no que se refere às melhorias em desempenhos de segurança resultantes de recomendações pósinvestigações. Em seu estudo, ele considera que as metodologias analisadas apresentam diferenças significativas em seus méritos relativos ("relative merit") e nos processos de seleção de decisões que adotam.

Favrot e Milbergue (1985) e Pham (1989) estudaram experiências de implantação do método de árvore de causas que depararam com dificuldades. Segundo eles, o problema maior não se refere à insuficiência do domínio da técnica por parte dos integrantes da empresa, e, sim, à não-utilização dos achados obtidos na investigação, no processo de correções posteriormente adotado. Segundo Favrot e Milbergue, muitas das árvores elaboradas no início da implantação da técnica eram deixadas intocadas em gavetas de superiores hierárquicos, fazendo com que, aos poucos, os responsáveis pela investigação fossem abandonando a busca das "causas das causas" e interrompendo, precocemente, as novas árvores.

Segundo Pham (1989), o aproveitamento das potencialidades do uso dessa técnica depende de negociação envolvendo o setor segurança e as demais gerências, de modo que o processo de implantação se faça de modo integrado com as demais políticas e práticas da empresa. 
Em 1986, discutindo sistemas de exploração de relatórios de acidentes do trabalho, após descrevê-los como fenômenos multicausais resultantes de disfunção em sistema homem/máquina capaz de apresentar uma ou mais origens, Ho e col. (1986) formulam a seguinte questão: Como fazer para descrever de modo rico e fidedigno um fenômeno complexo tal qual o acidente do trabalho, utilizando variáveis fáceis de manipular e tratar em computador?

De acordo com Simard (1989), as práticas de gestão da segurança escolhidas e adotadas na empresa dependem, em larga escala, da forma como a sua alta direção vê e se posiciona em relação à função segurança. Para ele, quando se conhece a resistência das chefias à segurança, compreende-se que tais práticas só têm chances de êxito se recebem apoio visível dessa direção e que, além dessas características estruturais, a gestão organizacional de riscos eficaz possui outras de ordem mais funcional.

\footnotetext{
"Este nível nos envia às atividades de prevenção propriamente ditas permitindo-nos observar que as empresas possuidoras de taxas mais baixas de acidentes praticam um conjunto de atividades de identificação sistemática de riscos e de análise de fatores de acidente: por exemplo, atividades tais como a inspeção frequente dos locais de trabalho e o recenseamento de condições perigosas, análise imediata de todos os acidentes e incidentes, análise de segurança das tarefas, elaboração e análise de estatísticas de acidentes. [..] constata-se também que as atividades de intervenção visando a prevenção de acidentes são de orientação sócio-técnica [...] intervindo-se sobre fatores técnico-materiais e sobre os fatores psicossociais e organizacionais dos acidentes" (Simard 1989, p. 81).
}

Dodier (1994) aponta como outro entrave possível ao aprofundamento da investigação a possibilidade de que ela venha a identificar aspectos que possam resultar em responsabilização da empresa. Segundo este último autor, um dos motivos da resistência do patronato francês contra a adoção do método de árvore de causas ou INRS foi justamente o fato de que, com a identificação de múltiplos fatores participantes do AT, tornava-se praticamente impossível atribuir responsabilidade pelo acidente ao próprio acidentado.

Em abril de 1994, e, posteriormente, em janeiro de 95, o Ministério do Trabalho e Emprego (Brasil 1994, 1995) divulgou proposta de mudança da Norma 
Regulamentadora 5 (NR 5), que determinava o uso obrigatório do método de árvore de causas pelas CIPAs, inclusive para investigações de doenças do trabalho. Essa proposta foi criticada por ignorar princípios elementares do método e, particularmente, por suas exigências em relação à necessidade de treinamento adequado, disponibilidade de tempo e aspectos de sua indicação (Binder 1997; Binder e Almeida 1995; Binder e col. 1997). Os autores citados lembram que o método não é obrigatório nem mesmo na França, onde foi desenvolvido há mais de 20 anos.

Em estudo de 1995, Cuny mostra que a adoção do método ADC, em empresas francesas não obrigadas a utilizá-lo, não é processo isento de erros. O autor analisa árvores de causas elaboradas por ex-alunos de cursos oferecidos pelo Institut National de Recherche et Sécurité - INRS - e mostra a ocorrência de erros na aplicação ou domínio de regras do método. A identificação desses erros é possível em sistemas dotados de mecanismos de acompanhamento de formandos.

Estudo de Almeida (1996) inclui quadro em que são listadas dificuldades presentes em investigações de acidentes. Trata-se de aspectos que podem ser considerados de natureza técnica ou associados ao próprio desenrolar do processo de trabalho, como ausência do acidentado no momento da(s) visita(s), mudança do cenário do acidente, presença de sistemas técnicos de grandes dimensões com painéis de comando fora do corpo da máquina, interações de tarefas, AT em atividade que aparece de modo limitado no tempo, etc.

Outra dificuldade constatada na experiência do autor refere-se ao uso de roteiros ou práticas de investigação adotados, seja por equipes de Centros de Referência em Saúde do Trabalhador, seja por auditores ligados ao Ministério do Trabalho, baseados na checagem da existência ou não de desrespeito a normas legais. Um dos inconvenientes dessa prática está no abandono da investigação de aspectos capazes de explicar como ocorreu o acidente em questão. Ou seja, quais os fatos ocorridos? Quais as condições do sistema que permitiram suas origens? Quais as formas de interação desses fatos que resultaram no acidente? A resposta a essas questões deixa de ser buscada, surgindo em seu lugar a busca de normas que 
deixaram de ser respeitadas no sistema. Nesses casos, o (des)preparo técnico da equipe de investigação e/ou dos seus interlocutores, na empresa, assume papel central na determinação do momento de término da coleta de dados.

Comentando experiência de empresa metalúrgica brasileira que ensaiava tentativa de implantação do método ADC, Oliveira F (1997) constata a existência de reações do discurso hegemônico às investidas desse novo referencial (p. 101), cita percepção de "dificuldades de aprendizagem da técnica e de aceitação de uma nova visão sobre os acidentes" (p. 102), aponta a persistência das concepções de ato inseguro e de culpa entre membros da equipe de segurança da empresa (p. 103) e conclui que as iniciativas de ruptura da concepção de causas baseada nas noções de ato inseguro e condição insegura "constituem contra-discursos que podem ou não se expressar em práticas de resistência às concepções que reduzem a explicação dos acidentes aos fatores individuais e estritamente psicológicos" (p. 104).

Os problemas apontados em iniciativa institucional de tornar obrigatório o uso do método ADC no Brasil, em experiências de sua difusão na França e no Brasil e em tentativas de implantação desse método em empresas constituem argumentos contrários às teses que defendem a adoção obrigatória de um método ou técnica de investigação oficial.

A constatação da existência de vantagens ou contribuições do uso de uma técnica, no enfrentamento de problemas identificados nas práticas de investigação vigentes, não deve ser interpretada como indicadora de que todas as razões presentes na gênese desses problemas seriam superadas com a adoção da técnica, considerada então como "solução mágica" e não mais como uma estratégia ou ferramenta, dentre várias, cuja utilização tem indicações que precisariam ser explicitadas. Além disso, ressalta-se o fato de que, respeitadas essas indicações e as regras e princípios desse método, aumentariam as possibilidades de benefícios associados a esse uso.

Os exemplos citados de dificuldades em experiências de utilização de método de investigação baseado em concepção sistêmica de acidente permitem apontar a necessidade de estudos complementares. Os problemas evidenciados nos estudos 
citados repetem-se? Mostram diferenças ou particularidades com raízes nos mesmos fatores já apontados ou surgem indícios de razões não evidenciadas até então cuja abordagem possa trazer novas contribuições para legisladores, profissionais da prevenção, pesquisadores interessados na produção e difusão do conhecimento, etc.? Por outro lado, o esclarecimento de questões como as apontadas pode contribuir com indicações que otimizem as possibilidades de utilização de outras das diversas técnicas de investigação de acidentes, inclusive daquelas difundidas mundialmente, por exemplo, com patrocínio da Organização Internacional do Trabalho.

Os fatos comentados sugerem que a abordagem de investigação desenvolvida no âmbito de empresas e de seus resultados assume grande importância para os interessados no desenvolvimento de práticas de prevenção de acidentes.

Almeida (1996), Almeida e col. (2000) descrevem entraves à condução de investigações de acidentes, realizadas por agentes externos às empresas. Os exemplos usados por esses autores mostram:

a) caso em que opinião prévia do trabalhador revela compreensão do acidente como fruto do azar (má sorte) ou descuido do acidentado;

b) caso em que proprietário de pequena empresa faz afirmações intimidativas, atribuindo o acidente à falha do acidentado e procurando encerrar a investigação;

c) caso em que profissional de segurança de uma grande empresa, em conjunto com chefia imediata do acidentado, omitiram informações e fizeram afirmações que modificavam, por completo, a história do acidente investigado.

Esses exemplos mostram elementos capazes de explicar, em parte, como se dá a construção dos limites de uma investigação de acidente.

Considerando a abordagem de acontecimento cuja origem e cujas explicações envolvem tantos e tão variados aspectos, seja num mesmo país, seja entre diferentes países do mundo, pode-se supor a persistência de aspectos das explicações desses 
mecanismos envolvidos na origem de acidentes ainda não adequadamente esclarecidos ou interpretados, que, se estudados, possam trazer à luz pistas ou indícios que auxiliem o esclarecimento de razões, seja de sua persistência em realidades locais, seja de diferenças na importância assumida por alguma dessas razões, nessas diversas realidades.

\subsection{Conseqüências das atribuições de causa e de culpa: a inibição da prevenção}

Embora a recomendação de prevenção seja apontada como parte da investigação de acidentes, inclusive nos roteiros de investigação propostos na legislação brasileira, em nosso país, praticamente, não se evidencia referência a meios de elaboração de sugestões e/ou critérios de escolha de medidas preconizadas.

Barreiros (1989) cita Volpato, para quem "a política de prevenção de acidentes na maioria das empresas de mineração da região de Criciúma concentra-se nas práticas do trabalhador e transfere a ele a responsabilidade de evitar o risco de acidentes ao mesmo tempo em que lhe impinge regras e regulamentos disciplinares, exigindo do trabalhador atos de submissão e obediência". De acordo com Barreiros (1996), a atribuição do trabalhador "resume-se em apontar ao supervisor as condições inadequadas ficando-lhe, entretanto, a obrigação de continuar executando suas atividades até que alguma providência seja tomada".

Segundo Garcia (1996), no meio rural, "a hierarquia dos princípios de controle de riscos da engenharia e da higiene do trabalho é subvertida pelo enfoque simplista, pois as principais ações de segurança [...] propostas para o controle dos riscos se limitam a medidas centradas no indivíduo sujeito aos riscos, como atitudes, precauções e práticas a serem seguidas no trabalho, treinamentos e uso de equipamentos de proteção individual” (p.198).

Em seu estudo, para 125 acidentes investigados, Binder, Azevedo e Almeida (1997) encontraram 144 propostas de prevenção, sendo que "a maioria delas (cerca de $80 \%$ ) situa-se no campo das estratégias comportamentais e mostra formulação 
como conscientizar, orientar, insistir em maior atenção, disciplinar e insistir no uso de equipamento de proteção individual” (p. 111).

Os casos citados ilustram abordagens de comportamentos humanos que desconsideram opiniões como as manifestadas por Feggetter (1982), Sulzer-Azaroff (1982, 1987) e Hoyos e Zimolong (1988), para quem a seleção de técnicas efetivas de modificação de comportamentos depende da descoberta de seus antecedentes e de suas consequiências. Feggeter (1982) propõe check-list para investigação de fatores humanos em acidentes da aviação e sugere sua utilização em outros tipos de acidentes. Sulzer-Azaroff (1987) propõe a técnica ABC (Antecedent, behaviour, Consequent) para pesquisar tais comportamentos e auxiliar na formulação de sugestões a serem adotadas pela empresa.

Assim, enquanto na literatura internacional multiplicam-se publicações apresentando o acidente do trabalho como fenômeno complexo e pluricausal, em investigações conduzidas no âmbito de empresas brasileiras, ele continua sendo apresentado como fenômeno simples e paucicausal. As práticas de prevenção levadas a cabo, em nosso meio, desconhecem o surgimento de tipologia de acidentes e de sistematização de métodos de análise "a priori” e "a posteriori” de acidentes (Carter e Corlett 1984; De Nève 1975; Dumaine 1985; Johnson 1973 e 1975; Monteau 1974 e 1979; Nolter e Johnson 1987; Monteau e Favaro 1990).

De forma semelhante, a prevenção de acidentes parece permanecer centrada em recomendações de mudanças do comportamento do acidentado, quando, na literatura internacional, surgem estudos incorporando contribuições da ergonomia, engenharia, engenharia de sistemas, sociologia, etc., apontando-se a responsabilidade das gerências em matéria de organização da segurança e das ações de prevenção de acidentes (Booth 1981; Hale e Glendon 1987a) e a necessidade de integração das políticas de segurança às políticas gerenciais das empresas (Pham 1989; Simard 1989; Simard e Marchand 1994; Hoffman e col. 1995; Monteau s/d).

Num breve resumo da evolução dos conhecimentos na área, pode-se elencar: 
a) explicita-se a necessidade de priorização da correção de situações de risco presentes, de maneira permanente, nos ambientes de trabalho, ou seja, eliminação de situações em que a segurança depende, exclusivamente, do desempenho do trabalhador na execução da tarefa (Wigglesworth 1976; Haddon Jr e Baker 1981; Baker e col. 1982);

b) evidencia-se, em países desenvolvidos, o esgotamento do potencial preventivo de medidas ditas técnicas e/ou tradicionais como proteção mecânica de máquinas e partes móveis de sistemas técnicos, organização, limpeza e melhorias do arranjo físico e disposição de peças e materiais em locais de trabalho, etc. (Wigglesworth 1972, 1976);

c) estabelecem-se critérios para a seleção de medidas de prevenção (Haddon Jr e Baker 1981; Baker e col. 1982; Gielen 1992);

d) difunde-se a noção de estratégias de prevenção com seus diferentes níveis de aplicação (Haddon Jr 1968, 1980; Waller 1987; Langley 1988; Brown 1990);

e) aponta-se a contribuição da organização e das relações sociais do trabalho na gênese dos acidentes (Nichols 1975; Dwyer e Raftery 1991);

f) ganha impulso e maior difusão o estudo da prevenção em sistemas sóciotécnicos de grande complexidade. Segundo Perrow, nesses sistemas, surgiriam acidentes inevitáveis, baseados em interação de falhas que, isoladamente, são consideradas banais (Perrow 1984; Monteau e Favaro 1990);

g) conformam-se duas grandes correntes de estudos acerca da segurança no trabalho. Uma delas dá ênfase ao estudo de aspectos cognitivos e da (con)fiabilidade no trabalho, com atenção especial no tema do erro humano, abordado como intrínseco ao processo de produção (Rasmussen e col. 1987; Kirwan 1992 a, b; Amalberti 1996). A outra enfatiza a gestão de segurança, apontando fatores organizacionais cuja superação exige abordagem que integre as funções de segurança, produção e manutenção (Monteau e Pham 1988; Monteau 1992). A 
associação de contribuições dessas duas correntes foi defendida por autores como Leplat e Rasmussen (1987) e Goguelin (1996).

Como a redução dos erros humanos é abordada na literatura que trata da prevenção de acidentes? Para Reason, a redução de erros poderia se dar: 1) pela supressão de condições associadas ao seu desencadeamento, consideradas erros latentes ou condições em potencial para a sua ocorrência; 2) pela introdução de próteses cognitivas que ajudem o operador em seus pontos "fracos"; 3 ) incorporando, no sistema sócio-técnico, defesas voltadas para a recuperação dos erros já ocorridos. Entre os tipos de defesas, ele cita o envolvimento de coletivos de trabalho, regulamentações, procedimentos, organização, gestão e, enfim, da técnica. Na visão desse autor, é o empilhamento de todas essas defesas ("placas") que confere, às vezes, ao sistema seu desempenho e seu nível de segurança global (Amalberti 1996, p. 220).

A noção de compromisso cognitivo proposta por Amalberti (1996) leva à formulação de crítica às abordagens de segurança centradas, exclusivamente, sobre os erros. Uma ação "sobre a detecção e a recuperação dos erros não seria suficiente para permitir ao operador o restabelecimento de seu equilíbrio cognitivo" (p. 44). A prevenção deve basear-se na descrição daquilo que serve de fundamento a esse compromisso cognitivo, à representação da situação e sua manutenção dentro de valores pertinentes para o sucesso da tarefa e a segurança do sistema. Para Amalberti, os objetivos da prevenção devem ser: a) não privar o operador de suas defesas naturais e não contrariá-las; b) deixar o operador regular seu compromisso, deixandolhe o controle da situação e dos riscos a correr ("de la prise de risque"); c) favorecer a visibilidade de suas próprias ações e das ações do sistema, para que ele regule os riscos que corre e suas defesas eficazmente e de modo coerente (p. 222).

Baumecker (2000) concorda com essa abordagem, ressaltando que a prevenção passa a exigir que "busquemos compreender na normalidade em que consistem esses compromissos" (p. 109). 
Kouabenan (1999d) destaca a importância de se levar em consideração a explicação causal "ingênua" do indivíduo comum, particularmente do próprio acidentado. Ele aponta o fato de a explicação "acerca do que se passou" representar uma necessidade das pessoas e acrescenta que a lógica da causalidade vista pela vítima "vem de suas experiências, de suas crenças, de suas percepções, de seu desejo de justiça, mas sobretudo de seu desejo legítimo de se crer com o domínio de seu mundo" ("Maître de son monde") (p. 239-240). Por fim, o autor afirma que o interesse da investigação das explicações ingênuas residiria justamente no fato de que

[...] essas crenças ingênuas (serem) frequentemente erradas ou enviezadas por estes valores e por interesses diversos [que poderiam] induzir comportamentos nefastos à segurança. [...] (Esse) viés do indivíduo pode ser fonte de infiabilidade [...] por favorecer comportamentos perigosos. [...] ao mesmo tempo, o conhecimento desse viés tem apreciável valor diagnóstico. Nós mostramos como os métodos especializados podem aproveitar esses conhecimentos ingênuos para aumentar a confiabilidade dos dados em que se baseiam as suas análises [e] para consolidar a credibilidade de medidas de segurança que daí decorrem.

Nós pensamos que as mensagens de prevenção melhorariam em eficácia e perspicácia ‘se integrassem os viezes defensivos mais comuns" (Kouabenan 1999d, p. 240).

É possível que a insuficiente difusão desses novos conhecimentos, em nosso país, esteja contribuindo para a proliferação de sugestões de medidas de prevenção centradas na mudança de comportamentos dos acidentados, sem questionar seu potencial preventivo. Tampouco foram efetuados, entre nós, estudos para avaliar o impacto de medidas de prevenção adotadas. Como exceção, merecem citação as publicações de Cohn e col. (1985) e Hirano e col. (1990), questionando a fragilidade técnica e as conseqüências político-ideológicas - como a "produção da consciência culposa" - dessa maneira de abordar os acidentes do trabalho.

Uma questão que incomodaria investigadores preocupados com as práticas de atribuição de culpa é: $O$ que deve ser feito, quando a investigação revela 'erros humanos'? Para o CCOHS (1998), toda vez que houver constatação desse tipo de fato, ele deve ser apontado, lembrando-se que a intenção é corrigir a situação e não 
punir um indivíduo. Deixar de apontar a falha diminui a qualidade da investigação e poderia facilitar a sua participação em futuros acidentes.

Comentando as conclusões da investigação, o CCOHS (1998) é explícito: "Nunca ${ }^{\mathbf{8}}$ faça recomendações disciplinares a uma pessoa ou pessoas que podem ter cometido uma falta. Isso poderia não somente ir contra o propósito real da investigação, mas poria em risco as chances do livre fluxo de informações em investigações futuras".

Na mesma publicação, sugere-se a utilização de recomendações específicas de correção dos problemas identificados, evitando-se redações que apenas apontam o problema a ser corrigido (CCOHS 1998).

\subsection{Estimulando o medo e atribuindo culpa: a prevenção de acidentes em materiais didático-educativos usados nas empresas}

Davillerd (1998) mostrou a utilização de mensagens que buscam atemorizar, culpar e/ou reforçar proibições, em cartazes franceses relativos à prevenção de acidentes dos olhos e de acidentes com cabelos soltos ou roupas folgadas, usados entre o início dos anos 50 e meados da década de 70. O autor descreve a seguinte trajetória de representação do tema, na França, entre 1949 e 1993:

a) Em 1949, os acidentes são representados de modo extremamente realista, e a culpabilidade do acidentado, ilustrada por reprimenda de superior hierárquico, devido ao não-uso de óculos de proteção.

b) Em 1950, imediato pós-guerra, a conseqüência nefasta do acidente (cegueira) é mostrada como ameaça à família, valor básico do momento.

c) Em 1955, surgem três abordagens diferentes da proteção dos olhos:

- o acidente é sugerido por meio de representações de atividades consideradas perigosas para os olhos, incluindo projeções de partículas, corpos estranhos,

\footnotetext{
${ }^{8}$ Grifo no original.
} 
etc. Essa noção de risco a evitar é retomada em 1965, com relação aos acidentes com cabelos soltos;

- a ênfase no uso de equipamentos de proteção individual;

- a ênfase em belezas da natureza em contraste com a fragilidade dos órgãos dos sentidos, omitindo-se referência direta ao acidente, que fica sugerido por meio de suas conseqüências.

d) Em 1959, com pergunta “por que não usar?”, incentiva-se reflexão acerca do nãouso de EPI, abandonando-se postura da reprimenda nessas situações.

e) Em 1970, adota-se generalização da mensagem, indicando-se necessidade de proteção dos olhos a ser escolhida pelo trabalhador, independentemente do contexto ou tipo de risco a que esteja exposto.

f) Em 1971, em relação aos acidentes com cabelos soltos, mantém-se referência ao risco específico, adotando-se contraste de cores, que ilustra em vermelho o comportamento desejável e em cinza aquele a ser evitado.

g) Em 1974, intensifica-se a abstração ou abordagem conceitual com cartaz que omite toda e qualquer referência ao local de trabalho e ao ser humano; a imagem de uma coruja com seus grandes olhos abertos é usada como "uma piscada de olhos" que busca conseguir a cumplicidade do trabalhador ao uso de medidas de proteção individual. No começo dos anos 80 , essa abordagem é estendida à prevenção de acidentes com cabelos soltos e roupas folgadas, associando-se mensagem que enfatiza necessidade de que sejam evitados no local de trabalho.

h) Em 1978, associa-se cifra relativa ao número médio de acidentes por dia que acometem os olhos à imagem de fileira de olhos, potencialmente em perigo, terminando com imagem de EPI a ser usado.

i) Em 1993, reaparece figura humana em imagem que sugere a tomada de consciência pessoal acerca do uso de EPI em vez de mensagens que buscam atemorizar, culpar e/ou reforçar proibições. 
Nos cartazes, há uso abundante de cores para destacar a imagem pretendida.

O autor mostrou que as ameaças aparecem, seja através da representação realista de condições envolvidas em acidentes, seja das consequiências destes para o acidentado e/ou para seus familiares. Ao longo de quase todo o período, há estímulos ao uso de equipamentos de proteção individual (EPI), sendo que, na fase inicial, incluíam-se até representações de reprimendas de superior hierárquico do acidentado, devido à não-utilização desses equipamentos. Com o passar do tempo, diminui a utilização de ameaças, como as referências diretas ao acidente e/ou às suas conseqüências, e surgem mensagens abstratas ou conceituais que omitem toda e qualquer referência ao local de trabalho e ao ser humano, embora se mantenham sugestões de uso de EPI. Utiliza-se também a informação que enfatiza a probabilidade de ocorrência de lesões.

Segundo Cohn e col. (1985), no Brasil, a responsabilidade direta dos empregadores pelos acidentes foi diluída nos textos legais e

"[...] nos materiais de campanha de prevenção de acidentes do trabalho, de cunho governamental ou promovida por iniciativa patronal, é inegável a difusão da idéia de que, em última instância, o culpado pelo acidente do trabalho é o próprio acidentado".

Os autores destacam o papel desempenhado pela Fundacentro, órgão do Ministério do Trabalho, nesse processo "produção da consciência culposa". Em suas publicações, 98\% dos acidentes são atribuídos aos "atos inseguros [...] comportamentos emitidos pelo trabalhador que podem levá-lo a sofrer acidente".

Comentando o uso de cartazes de segurança em empresas brasileiras, Cohn e col. (1985, p.146 e seguintes) apontam os seguintes aspectos:

a) A maioria dos cartazes contém afirmações imperativas, precedidas das expressões “Atenção", "Pense”, "Perigo”, etc.

b) São enfatizados os cartazes que induzem o trabalhador, direta ou indiretamente, a assumir a total responsabilidade pelo acidente, às vezes com forte apelo emocional. 
De acordo com o mesmo material,

"criar uma mentalidade prevencionista [...] significa persuadir os trabalhadores em seu conjunto no sentido de fazê-los acreditar que, embora os fatores que causam os acidentes estejam presentes, é ao trabalhador que é conferida a capacidade de evitá-los".

Para melhor discutir o uso de tentativas de estímulo do medo, em materiais didáticos e/ou de divulgação acerca da prevenção de acidentes, apresenta-se, a seguir, breve resumo da literatura a respeito, com ênfase em estudos de psicologia, campo em que se concentra a maioria dos estudos encontrados.

Levanthal e col. (1965) encontraram evidências de que o despertar do medo resulta em atitudes mais favoráveis em relação à adoção de medidas preventivas, no entanto, mudanças reais de comportamento, no sentido da prevenção, foram mais freqüentes entre pessoas que receberam plano ou informação específica para a ação, embora a existência isolada desses planos não tenha sido suficiente para o seu desenvolvimento. As diferenças foram estatisticamente significantes. $\mathrm{Na}$ opinião desses autores, diversos fatores podem interferir nesses tipos de estudos, como, por exemplo:

a) a disponibilidade da ação recomendada. A persuasão aumenta quando as ações estão disponíveis imediatamente;

b) a "intensidade" ou "nível" do medo. Medo intenso produz resposta defensiva e diminui a adesão às recomendações;

c) o tipo de medo ou ameaça usado no estudo;

d) posição inicial do sujeito. Pessoas previamente favoráveis à mudança recomendada aumentam a adesão à mesma, e pessoas previamente em oposição podem fortalecer sua rejeição.

Quando as condições ambientais e as características de disposição dos indivíduos ("subjects dispositional characteristics") fazem a ação parecer altamente 
possível e efetiva, o despertar do medo (“arousal of fear") resulta em mudanças nas atitudes e nas ações.

O despertar de emoções, como o medo, é necessário para mudança em atitudes e em comportamentos, parecendo ser suficiente para a primeira e apenas necessário para a segunda (Levanthal e col. 1965).

No estudo citado, os autores constataram que receber informações específicas influencia o estado emocional dos indivíduos, inibindo certos estados de medo.

Por que a mudança de comportamento (ação) não ocorre naqueles casos em que se evidencia expressiva mudança de atitude? Levanthal e col. (1965) acreditam que isso pode decorrer do fato de os efeitos do medo dissiparem-se rapidamente com o tempo. E, enquanto a atitude é medida por ocasião da exposição ao estímulo (medo), a ação ocorre depois que os efeitos da atitude induzida pelo medo já foram dissipados.

Depois de registrar que estudos sociológicos acerca de acidentes do trabalho costumam apontar a ocorrência de perturbações no processo de trabalho usual, de violações de regras de segurança e de tentativas de restauração da produção, Nichols (1975) discute o que pode levar um trabalhador a assumir práticas perigosas. Para ele, permanecer no local de trabalho e não fazer nada na vigência de uma perturbação na atividade realizada "[...] significa permanecer do lado de fora do ritmo de produção: mas este ritmo é a única coisa que faz toleráveis muitas tarefas". Outro aspecto que pode contribuir para essa intervenção do trabalhador é o seu conhecimento de que, sem a correção da perturbação, advêm aumentos nas cargas de trabalho dele e de seus colegas.

Em estudo de Rogers e Mewborn (1976), os efeitos da persuasão de eventos ameaçadores nocivos mostram-se associados com a probabilidade de ocorrência desse tipo de evento e com a eficácia da medida de proteção recomendada. Estas duas condições estão associadas com aumento da intenção de adotar a medida recomendada. Quando a medida preventiva é efetiva, aumentos em sua probabilidade e nocividade facilitam a mudança de atitude. Entretanto, quando as respostas de 
enfrentamento ("coping") não são efetivas, aumentos na probabilidade e na nocividade do evento não têm efeitos ou tem efeitos deletérios. Os efeitos dessa interação foram considerados em termos de evitação defensiva, tendo como componente crucial a incapacidade para evitar o perigo.

Os autores destacam como implicação prática desse achado a importância a ser dada pela mídia na capacidade de controle das medidas recomendadas em relação aos eventos nocivos abordados. Reforça-se também a defesa de instruções de ação específicas como facilitadoras da adesão a mudanças de comportamento.

A eficácia das recomendações age sobre as intenções, reforçando as crenças nas capacidades ou habilidades de enfrentamento do perigo e não fazendo com que a gravidade ou a probabilidade deste pareçam menores.

A manipulação do estímulo que visa despertar o medo não interfere de modo importante na intenção das pessoas pesquisadas. A natureza transitória da emoção do medo, que cai rapidamente após a cessação do estímulo, é apontada pelos autores como uma das possíveis razões para a falha desse estímulo.

Segundo Rogers e Mewborn (1976), as principais variáveis ou componentes a serem consideradas na abordagem de estímulo (“arousal”) ao medo são:

a) a magnitude da nocividade do evento ameaçador;

b) a probabilidade de sua ocorrência, se não for adotada nenhuma atividade de adaptação;

c) a eficácia da medida recomendada, que poderia evitar o evento nocivo.

Assume-se a idéia ou pressuposto de que a tendência de se praticar um determinado ato é função da expectativa de que esse ato será seguido por determinada conseqüência e do valor dessa conseqüência.

Segundo esses autores, o despertar do medo inicia, para cada um dos 3 componentes citados, processos cognitivos, implicando em avaliações das 
informações comunicadas relativas à nocividade, probabilidade e eficácia. $\mathrm{Na}$ mediação de mudanças de atitudes e de comportamentos humanos, esses processos cognitivos são mais importantes do que o estado emocional de medo. Essas idéias resumem a "Teoria da motivação da proteção ("Protection motivation Theory"), segundo a qual a motivação seria função associada à interação desses 3 processos (Rogers e Mewborn 1976).

McKenna e Glendon (1980) comentam que o medo e a ansiedade engendrada pela propaganda do horror podem dificultar ou opor-se à eficiência da prevenção e afirmam que treinamentos em primeiros socorros podem representar alternativa benigna ao horror ou à experiência de lesões, produzindo mudanças na motivação face ao perigo.

Estudando taxas de acidentes em duas empresas, McKenna e Hale (1982) encontraram melhoria da acidentalidade em empresa que introduziu treinamento em primeiros socorros. Entrevistas realizadas antes e após (6 meses) o treinamento, com treinandos e com controles (pareados segundo diversos critérios: idade, sexo, experiência, nacionalidade...) de empresa sem o treinamento, mostraram, nos treinandos, aumento na percepção de responsabilidade de tomar ações para evitar lesões e em sua inclinação ou intenção ("willingness") de adotar comportamentos seguros. Estas mudanças foram atribuídas ao aumento de seus conhecimentos acerca das conseqüências das lesões.

Dejoy (1985) afirma: "Dado que os trabalhadores são mais propensos a verem seus problemas de segurança como originários de causas situacionais ou ambientais, tentar melhorar a segurança com programas de incentivo, posters, regras e regulamentos adicionais e obrigações progressivas ("stepped-up enforcement") corre contra a percepção de causas predominante entre eles”.

McKenna e col. (1991) citam a existência de evidências de que aqueles que recebem treinamento pensam mais profunda (“deeply”) e racionalmente acerca de perigos e lesões. Destacam a importância de elementos racionais do conhecimento das ações de prevenção corretas e da crença na eficácia da prevenção. 
McKenna e col. (1991) e também Kouabenan (1999b) comentam o fato de comportamentos de pessoas expostas a perigo parecerem, às vezes, irracionais e também a aparente incompreensão dessas pessoas em relação a determinadas medidas de segurança cujo uso ou adoção se baseia em medições objetivas de riscos, como, por exemplo, o uso de cintos de segurança. Segundo os autores, a irracionalidade de tais comportamentos é apenas aparente. Afinal, os indivíduos podem não só receber feed-back positivo de seus comportamentos perigosos, por exemplo, não se acidentando, como desenvolver crença de que os acidentes acontecem apenas com os outros.

Entre motoristas, encontra-se percepção de invulnerabilidade, ou seja, enquanto grupo eles classificam suas habilidades como melhores que as da média. Essa ilusão de controle é mais consistente com uma auto-avaliação positiva do que com uma avaliação negativa em relação aos demais motoristas. A possibilidade de implicações negativas associadas com essa percepção de "seu poder de controle", como a subestimação de riscos e a ocorrência de acidentes, é apontada por McKenna e col (1991) e por Rumar (1988, citado por Kouabenan 1999c, p. 227).

Esses achados estão em consonância com os de Tyler e Cook (1984, citados por Kouabenan 1999c, p. 227), para quem "as campanhas de segurança através da mídia só afetam o risco percebido ao nível da sociedade em seu conjunto e não o risco percebido ao nível individual, o risco para si”.

Segundo McKenna e col. (1991), no caso dos motoristas, a superação da ilusão de controle é facilitada se a mesma não operar em todas as suas habilidades ou capacidades ("driving skill”), indicando a existência de áreas que podem ser úteis na sensibilização de pessoas para as possibilidades de mensagens de segurança. Em seu estudo, esses autores encontram menor auto-avaliação de habilidades entre mulheres, indicando que o uso dessas técnicas de sensibilização pode ser mais apropriado para esse grupo.

Segundo Wogalter e col. (1999), os avisos, dados a consumidores, que enfatizam a gravidade maior de possíveis conseqüências resultam em maior adesão a 
comportamentos do que aqueles que se referem à menor gravidade, apenas nos casos de lesões pouco prováveis. A gravidade das lesões potenciais foi considerada pelos autores preditor de percepção (julgamento) de riscos mais importante do que a probabilidade de ocorrência dessas lesões. Para os autores, os avisos devem enfatizar "quão gravemente uma pessoa pode ferir-se mais do que a probabilidade de ferir-se".

Kouabenan (1999c, p. 228) questiona a importância da ilusão de otimismo, indicando que fatores, como o conforto do uso ou adoção da medida e as normas sociais, como a adesão de grande quantidade de pessoas à sua adoção, podem ser mais importantes do que ela. Na sua opinião, "essas diferentes informações podem ser utilmente exploradas para informar e formar as pessoas sobre os riscos e para compreender e prever as reações do público [...]. As campanhas devem incluir, judiciosamente, um débil, mas real nível de medo ou de ameaça. Uma ameaça exagerada pode suscitar reações de defesa e de fuga ("d'évitement"), tais como a ilusão de superioridade".

Entre os aspectos que parecem permanecer não esclarecidos, pode-se citar: a relação entre processos cognitivos e emoções e as influências ou diferenças que ocorrem em coletivos de trabalho. Como interferem em percepções, atitudes e comportamentos? Existirá modelo aplicável a todas as situações com variações em função de cada realidade? Haverá leque de modelos com alternativas diferentes em função de particularidades? Serão diversas as possibilidades de inter-relações numa dada realidade, em função de diferenças nos elementos presentes em cada modelo? Serão as diferenças possíveis relacionadas apenas às diferenças de respostas dos diversos elementos às interpelações provenientes dos demais elementos presentes na situação e/ou de suas interações?

A figura 1 mostra modelo de comportamento adaptado a partir de Dejoy (1996). Segundo a sistematização proposta, face ao perigo, o comportamento do trabalhador inclui etapas de avaliação, tomada de decisão, iniciação e, por fím, aderência ao comportamento. Essas etapas são cumulativas, ou seja, somente após avaliar uma situação como perigosa, o trabalhador toma a decisão de assumir uma atitude ou disposição de autoprevenção ou evitação desse perigo. Por sua vez, essa 
atitude é indispensável para o início de comportamentos de autoprevenção, aos quais, posteriormente, o trabalhador pode aderir de forma duradoura. Ao considerar de forma negativa cada uma dessas etapas, o trabalhador expõe-se ao risco de lesão ou de doença no trabalho.

Por sua vez, cada uma dessas etapas é influenciada por condições diversas. Ou seja, enquanto a avaliação de uma situação depende, principalmente, de como o indivíduo a concebe, por exemplo, como perigosa ou não, a adesão desse indivíduo a um comportamento ou medida de proteção varia com o ambiente ou clima da empresa, isto é, com a forma como ele avalia a adesão de seus companheiros de trabalho e superiores hierárquicos a esse mesmo comportamento.

As opiniões dos autores citados mostram a persistência de divergências acerca do tema "comportamentos face ao perigo". As sistematizações buscadas na elaboração de modelos explicativos de comportamentos face ao perigo parecem representar importante contribuição no sentido da construção de um consenso entre especialistas. Outra contribuição trazida pelos modelos e que não deve ser menosprezada está na importância, por eles atribuída, à necessidade de esclarecimento das razões envolvidas na gênese dos comportamentos.

Essa forma de abordagem contrapõe-se às práticas simplificadoras, tão difundidas em nosso meio, seja enquanto explicação ou conclusão de investigação de acidentes, seja em termos de recomendação genérica de treinamentos apresentada como medidas de prevenção. O modelo apresentado mostra a importância do diagnóstico da etapa do comportamento em que se encontra a população trabalhadora, como ponto de partida para a identificação de aspectos a serem implementados com vistas à obtenção de comportamentos de autoprevenção.

As quatro etapas desse comportamento de autoprevenção estão associadas a conjunto de fatores do indivíduo: "crenças acerca de ameaças", "crença de autoeficácia" ou de capacidade de cumprir a contento a medida proposta, "crença na eficácia da resposta contra o perigo", "existência de fatores que facilitem ou dificultem a adoção do comportamento" e "aspectos do ambiente ou clima de 


\begin{tabular}{|c|c|c|c|c|c|c|}
\hline \multicolumn{7}{|c|}{$\begin{array}{l}\text { Figura 2. Modelo de comportamento de auto proteção no trabalho: etapas e } \\
\text { importância de crenças ou percepções do individuo que as influenciam. }\end{array}$} \\
\hline Perigo & $\stackrel{\text { Sim }}{\longrightarrow \text { Avalia }}$ & $\stackrel{\operatorname{sim}}{\longrightarrow}$ & $\begin{array}{l}\text { Toma } \\
\text { decisão }\end{array}$ & $\stackrel{\operatorname{sim}}{\longrightarrow}$ & $\begin{array}{l}\text { Inicia } \\
\text { ação }\end{array}$ & $\stackrel{\text { Sim }}{\longrightarrow}$ Adere \\
\hline$\frac{\text { Acerca de }}{\text { ameacas }}$ & $\mathbf{P}$ & & $s$ & & $s$ & s \\
\hline $\begin{array}{r}\text { Capacidade de } \\
\text { cumprir a medida }\end{array}$ & $\mathbf{P}$ & & $\mathbf{P}$ & & s & $s$ \\
\hline Eficácia da medida & $s$ & & $\mathbf{P}$ & & $S$ & $S$ \\
\hline$\frac{\text { Facilitadores e ou }}{\text { barreiras }}$ & $s$ & & $\mathbf{P}$ & & $\mathbf{P}$ & $\mathbf{P}$ \\
\hline $\begin{array}{c}\text { Clima de segurança } \\
\text { ou "ambiente" }\end{array}$ & $s$ & & $\mathbf{P}$ & & $\mathbf{P}$ & $\mathbf{P}$ \\
\hline$P=$ Principal. & Não & & $\downarrow^{\text {Não }}$ & & $\downarrow^{N a ̃ o}$ & \rfloor$^{N a ̃ o}$ \\
\hline$S=$ Secundária. & \multicolumn{6}{|c|}{ Exposição ao risco de lesão ou doença } \\
\hline
\end{tabular}


segurança existente na empresa". O peso de cada um desses aspectos varia em função da etapa de comportamento em que está a população trabalhadora em questão, ou seja, as crenças acerca da chance de sofrer um acidente e da gravidade potencial de lesão daí decorrente influenciam, sobretudo, a etapa de avaliação dessa situação como perigosa ou não, porém têm importância secundária para a etapa de aderência a um comportamento de autoprevenção contra esse mesmo perigo. E assim por diante, conforme indicado na figura.

Os modelos parecem incorporar avanços ao incluírem aspectos associados que ultrapassam o limite dos "fatores internos ao indivíduo", no entanto, permanecem merecendo novos estudos e, em particular, testes que verifiquem até que ponto seriam aplicáveis em diferentes áreas da vida cotidiana. Além disso, persistem aspectos já citados anteriormente que não estão incorporados nesses modelos, como aqueles relacionados à possibilidade de explicações defensivas ou afins e causais de natureza leiga ou "ingênua" ("naive"), à abordagem de aspectos cognitivos individuais e coletivos - da atividade, da tarefa e de suas interações com as emoções e vida afetiva do trabalhador, entre outros. 


\section{OBJETIVOS}

Descrever como são registradas:

a) as informações obtidas em investigações de acidentes do trabalho, realizadas segundo o modelo do Ministério do Trabalho (Anexo 2 da Norma Regulamentadora $\mathrm{n}^{\circ}$ 5) ou outro, eventualmente adotado pela empresa;

b) as medidas de prevenção propostas a partir das investigações.

Identificar, nos registros das investigações, o uso de palavras e/ou expressões indicativas de emissão de juízo de valor acerca do comportamento dos trabalhadores, direta ou indiretamente, envolvidos no acidente.

Verificar se existem empresas que utilizam o Método de Árvore de Causas (ADC) para investigação de acidentes e, nessas, analisar os relatos de acidentes registrados, as árvores construídas e as medidas de prevenção propostas.

Identificar a existência de interrupção precoce das análises de AT, superficialidade ou outras falhas que permitam apontar limites ou insuficiências nas práticas adotadas nas empresas abordadas.

Analisar os materiais didáticos e de prevenção de acidentes do trabalho utilizados pelas empresas, visando identificar:

a) a concepção de causa de acidentes do trabalho adotada;

b) as recomendações existentes sobre condução de investigações de acidentes do trabalho. 


\section{MATERIAL E MÉTODOS}

\subsection{Material}

Em empresas localizadas no município de Botucatu - SP., possuidoras de Comissão Interna de Prevenção de Acidentes, registradas no Ministério do Trabalho, foram obtidos os seguintes materiais:

? apostilas, cópias de transparências, lista de frases divulgadas em contracheques, cópias de ordens de serviço e outros materiais didáticos e instrucionais, bem como formulários para registro das investigações de acidentes do trabalho referentes ao período de $1^{\circ}$ de janeiro a 31 de dezembro de 1997, conforme exigências das Normas Regulamentadoras números 5 (NR 5: Anexo II - Ficha de análise de acidentes Anexo 1) e 18 (NR 18: Anexo I - Ficha de acidente do trabalho - Anexo 2) do Ministério do Trabalho (BRASIL 1998) ou outros elaborados com base nesses documentos.

\subsection{Métodos}

\subsubsection{Obtenção da relação de empresas possuidoras de CIPA, registradas no Ministério do Trabalho e Emprego, no ano de 1997}

Foi obtida, junto à Subdelegacia do Ministério do Trabalho e Emprego de Bauru, a relação de empresas do município de Botucatu que constavam como possuidoras de CIPA, com registro no "Livro de Registro de CIPA" da referida Subdelegacia, até 31 de dezembro de 1997.

\subsubsection{Obtenção da relação de empresas que tiveram acidente do trabalho registrado junto à Previdência Social, no ano de 1997}

Esta relação foi obtida em banco de dados do Programa de Saúde do Trabalhador de Botucatu, construído a partir das informações contidas nas comunicações de acidentes do trabalho - CATs -, emitidas e encaminhadas ao Instituto Nacional de Seguridade Social - Agência de Botucatu. Foram extraídas 
listagens contendo nome da empresa, número de inscrição no Cadastro Geral de Contribuintes - CGC - e número de acidentes notificados ao INSS, em 1997.

\subsubsection{Identificação de empresas possuidoras de CIPA que tiveram acidente registrado no ano de 1997}

a) Pelo cruzamento das informações obtidas nos itens "3.2.1 Obtenção da relação de empresas possuidoras de CIPA, registradas no Ministério do Trabalho e Emprego, no ano de 1997" e "3.2.2 Obtenção da relação de empresas que tiveram acidente do trabalho registrado junto à Previdência Social, no ano de 1997”, foram identificadas as empresas possuidoras de CIPA que tiveram acidentes registrados nesse ano.

b) Por telefone, foram obtidas informações complementares, tanto das empresas descritas como possuidoras de CIPA que não mostravam registro de acidente(s) quanto daquelas com acidente registrado que não constavam da lista de empresas possuidoras de CIPA:

- A empresa continuava na ativa com CIPA desativada sem comunicação ao MTE?

- A empresa continuava funcionando normalmente e não houve acidente registrado naquele ano?

- A Empresa fora desativada?

- A empresa possuía CIPA não registrada no MTE? Nos casos confirmados, houve solicitação de cópias de todos os documentos que compõem o material do presente estudo.

c) De modo complementar, as empresas que apresentaram registro de acidente e não apareceram relacionadas como possuidoras de CIPA foram contatadas, visando esclarecer se possuíam ou não a referida comissão e, sendo o caso, sua situação junto ao Ministério do Trabalho. 


\subsubsection{Obtenção dos materiais junto às empresas}

Foi realizada por meio de solicitação da Diretoria Técnica de Vigilância Sanitária da Diretoria Regional de Saúde - DIR XI, sediada em Botucatu.

\subsubsection{Instrumentos de coleta de material}

Foram elaborados três diferentes formulários para coleta de dados:

$\checkmark$ ficha de entrada de dados de investigação (Anexo 3)

$\checkmark$ ficha de entrada de dados de árvore de causas (Anexo 4)

$\checkmark$ ficha de registro de informações referentes a materiais didáticos e instrucionais (Anexo 5)

\subsubsection{Transcrição e classificação de informações}

\subsubsection{Relativas aos registros de investigações de acidentes}

As informações contidas nos documentos relativos à investigação de acidentes foram, conforme o caso, transcritas e/ou classificadas para a ficha de entrada de dados de investigação ou para a ficha de entrada de dados de árvore de causas. A transcrição e a classificação foram feitas pelo autor, utilizando os instrumentos citados, elaborados de modo a permitir a classificação de informações.

Nos casos em que a empresa não tinha preenchido as fichas de análise de acidentes exigidas pelas normas regulamentadoras de números 5 e/ou 18, mas tinha utilizado outro tipo de investigação, particularmente, o método de árvore de causas, as informações constantes dos registros da empresa (descrição do acidente, conclusão da investigação e medidas de prevenção recomendadas) foram classificadas e transcritas para a ficha de entrada de dados de investigação.

A análise de informações relativas a acidentes investigados com o método de árvore de causas foi feita conforme descrição a seguir. 
Após a análise com vistas a uso de palavras listadas na ficha de entrada de dados e classificação das medidas preventivas, os documentos relativos a essas investigações foram duplicados e lidos, cuidadosamente, pelo autor para identificação de falhas a serem registradas, conforme disposto na ficha de análise de árvores de causas (Anexo no 4).

Para cada investigação com o método ADC foram analisados os fatos ou fatores de acidente registrados e os esquemas ou árvores elaborados quanto:

- à clareza e precisão da redação ou denominação de cada fato.

Os nomes dados a cada fato foram revistos de modo a verificar se seguiam recomendações descritas para o método (Monteau 1974; Cuny 1995; Binder 1997), ou seja:

a) redação de frase curta com sujeito, verbo e complemento, se necessário;

b) representar sempre um só fato, ou seja, não juntar dois ou mais fatos em uma só denominação;

c) corresponder a fato objetivo, passível de observação, evitando-se registro de emissões de juízo de valor, interpretações e conclusões como se fossem fatos;

d) negações ou ausências que constituem características habituais da atividade e que não deveriam ser incluídas na árvore.

- ao uso de categorias de análise definidas pelos criadores do método.

Verificar se foi usado o conceito de atividade e seus 4 componentes indivíduo, tarefa, material e meio de trabalho - para descrição da atividade realizada por ocasião do acidente e classificação dos fatos de cada componente, segundo fatos habituais e variações.

- à representação gráfica dos fatos e das relações estabelecidas entre eles. 
Verificar se os símbolos adotados para representar os fatos eram os mesmos propostos pelos criadores do método ou se houve utilização de outros, descrevendo eventuais diferenças.

Verificar se as relações entre fatos, representadas em cada esquema, foram as mesmas definidas no método, ou seja, cadeia ou encadeamento, conjunção, disjunção e super ou sobredeterminação ou utilização de configuração que inclui erro de representação lógica ou de outro tipo. Descrever os erros identificados.

- aos fatos representados como terminais.

Identificar os fatos registrados como terminais na análise, seja nas árvores, seja nas descrições de acidentes.

Identificar a existência de variações representadas como fatos terminais, no esquema, e verificar se suas origens foram investigadas, se há registros de razões para a parada.

- à natureza da relação existente entre fatos antecedentes e conseqüentes.

Verificar se as relações mostradas entre fatos são lógicas, indicando que, de acordo com o tipo de relação, o(s) antecedente(s) foi (foram) realmente necessário(s), ou necessário(s) e suficiente(s), para origem do conseqüente.

Quantificar o número de erros de relação lógica entre fatos para cada árvore.

•às medidas de prevenção indicadas.

Verificar se os fatos registrados nas árvores foram explorados na formulação de recomendações de prevenção.

Analisar as medidas propostas em relação a uso ou não de critérios de seleção de medidas (Méric e col. 1976).

- à indicação de uso do método de árvore de causas. 
Considerando a tipologia de acidentes proposta por Monteau (1992) e a de empresas proposta por Wisner (1983), classificou-se o uso do método como supérfluo (desnecessário), interessante ou particularmente indicado (Binder e col. 1999).

Ao final da análise de cada AT, considerando a descrição e a árvore elaborada na empresa, definiu-se, para cada acidente, se os dados registrados permitiam compreender ou "enxergar" como o acidente acontecera.

A lista de fatos elaborada a partir dos registros da investigação conduzida na empresa foi analisada, visando à identificação de fatos, ações ou aspectos cujas origens não foram investigadas e que poderiam revelar-se úteis à prevenção de acidentes.

\subsubsection{Relativas aos materiais didático-instrucionais}

As informações contidas em materiais didáticos, instrucionais e de divulgação usados nas empresas foram analisadas da seguinte maneira:

Inicialmente, o material foi classificado segundo tipo, separando-se os grupos:

- apostilas e textos usados em treinamentos, oferecidos a membros de CIPA;

- exemplos de investigações de acidentes apresentados em treinamentos ou formação de membros de CIPA ou pessoal técnico que participa de análises de acidentes;

- Frases de segurança e recomendações de prevenção, presentes em cartazes e material de divulgação usado na empresa;

- outros (sempre que possível, especificar de acordo com o material).

Em seguida, o material foi lido e relido, cuidadosamente, pelo autor, visando identificar: 
- concepções de causas de acidentes (dicotomia ato inseguro/condição insegura, teoria do dominó, disfunção em sistema ou outras);

- orientações relativas a investigações de acidentes (preparação, cuidados a serem adotados, rotinas de procedimentos, check -lists, preservação de local, formas de registro dos achados e outras);

- recomendações de prevenção (referência a qualquer um dos aspectos citados no item 9 da "Ficha de entrada de dados de investigação");

- outras referências a causa(s) e/ou investigação de acidente(s).

\subsubsection{Criação de bancos de dados e emissão de relatórios para análise}

Com os dados coletados, construiu-se e gerenciou-se banco de dados, utilizando-se o EPI Info, versão 6.04b, 1997.

Os dados das fichas de investigação de acidentes foram consolidados para o universo de empresas informantes e analisados.

Os dados das fichas de análise de materiais didático-instrucionais foram consolidados por empresas, e, conforme o caso, para o universo de empresas informantes. 


\section{RESULTADOS E DISCUSSÃO}

\subsection{O universo de empresas estudadas}

A tabela 1 mostra a situação de 64 empresas que foram identificadas como possuidoras de Comissões Internas de Prevenção de Acidentes (CIPA), no município de Botucatu, no ano de 1997. Destas, 63 constavam no Livro de Registro de CIPA da Subdelegacia do Trabalho e Emprego de Bauru, como tendo essa comissão em funcionamento no ano de 1997. A outra empresa foi identificada a partir de consulta direta, realizada pelo pesquisador junto a 12 empresas que tiveram mais de 1 acidente registrado no Instituto Nacional de Seguridade Social - INSS, no ano em questão. As outras 11 empresas não necessitavam instalar CIPA, de acordo com os critérios legais vigentes.

Tabela 1. Empresas de Botucatu, possuidoras de CIPA, no ano de 1997, segundo situação em relação à ocorrência de acidente do trabalho, funcionamento da CIPA e resposta à solicitação de documentos relativos à investigação de acidentes ocorridos nesse ano. Botucatu, SP, 2000.

Situação das empresas $\mathrm{N}^{\mathbf{0}}$ de empresas

Responderam à solicitação 27

Investigaram todos os AT registrados ou mais

Investigaram parte dos AT registrados

Não investigaram nenhum dos AT registrados

Empresa fechada

Do total de 64 empresas, 24 não tiveram acidente do trabalho registrado junto

à Previdência Social, fato verificado, seja pela pesquisa de acidente, no banco de dados disponível no Programa de Saúde do Trabalhador (PST) da Diretoria Regional de Saúde de Botucatu, DIR XI, seja por contato direto do pesquisador com a empresa. Das 40 restantes, 27 responderam à solicitação de cópias de material (fichas de investigações adotadas na empresa, cópia de investigações de acidentes ocorridos 
no ano de 1997, material usado em formação de cipeiros e prevenção de acidentes na empresa), tendo 7 delas investigado a totalidade dos AT registrados com comunicação de acidente do trabalho (CAT) junto à Previdência Social, 11 investigado parte e 09 não tendo investigado nenhum dos AT notificados.

A busca de informações acerca das demais 13 empresas permitiu constatar que, em 3 casos, a CIPA havia sido extinta devido à diminuição do efetivo da empresa, sem que houvesse a respectiva baixa junto à representação do Ministério do Trabalho e Emprego (MTE). O mesmo aconteceu no caso de 5 empresas que haviam sido comprovadamente fechadas e, provavelmente, com outras 5 que não foram localizadas, apesar de busca em catálogo telefônico e consultas diversas, inclusive visita ao endereço indicado no Livro de Registro, que resultaram infrutíferas. Conforme esperado, não existiam registros de acidentes do trabalho relativos a essas 13 empresas, no banco de dados formado a partir das comunicações de acidentes do trabalho.

Esses achados mostram que, das 64 empresas inicialmente identificadas como possuidoras de CIPA, no ano do estudo, esta comissão não existia em 13, sendo que, em 10 casos, a própria empresa não existia mais. Nas 51 empresas restantes, 27 apresentaram registro de acidentes e 24 não tiveram acidente registrado.

Alguns casos merecem registros especiais. Em 3 empresas, o número de acidentes típicos investigados foi maior que o de registrados. Uma fábrica de conglomerados ou chapas de madeira, que entregou material referente a 71 investigações de acidentes ocorridos no ano, mostrava registros de "apenas" 41 acidentes, no banco de dados formado a partir das CAT recebidas pelo PST. Uma fábrica de aviões, que teve apenas 1 acidente identificado no banco de dados, entregou cópias de 7 investigações realizadas no ano.

A maioria das empresas que não investigou os acidentes ocorridos não possuía Sesmt, embora estivesse com suas CIPA estruturadas e com o preenchimento dos documentos encaminhados ao Ministério do Trabalho e Emprego em dia. Das empresas que não investigaram a totalidade dos acidentes típicos identificados no banco de dados de CAT, merecem destaque: 
a) uma, do ramo de atividade química, que, apesar de possuir Serviço Especializado em Engenharia de Segurança e Medicina do Trabalho (Sesmt) estruturado no ano do estudo, registrou 22 acidentes e não investigou nenhum deles;

b) um serviço público, também possuidor de Sesmt, que registrou 31 acidentes e investigou apenas 1 ;

c) uma empresa estatal do ramo de transportes que, no ano de 97, promovia programas de demissões incentivadas e desmontava o seu Sesmt, que registrou 11 acidentes e nenhuma investigação;

d) uma empresa de serviços com 27 acidentes registrados e nenhum investigado;

e) uma empresa de construção civil, que comprava serviços de empresa de assessoria de segurança, a qual investigou 3 de 17 acidentes registrados.

Por outro lado, houve empresas que investigaram mais acidentes do que o total registrado no sistema de informações do PST. Essas duas ocorrências revelam insuficiências desse sistema em relação ao seu objetivo de detecção de acidentes ocorridos. Entre as hipóteses capazes de explicar o número de investigações superior ao de registros, duas parecem ser mais importantes:

a) a perda ou extravio de informações recebidas pela Previdência Social, seja no arquivamento na Agência local do INSS, seja após a remessa de cópias das CAT para o Serviço de Saúde até sua recepção no PST pelos encarregados da recepção, codificação, digitação dos dados e posterior emissão de relatórios;

b) a falta de emissão de CATs, pela empresa, ou o extravio de parte destas, antes de sua chegada ao INSS. Nos casos de acidentes considerados mais leves, a não-emissão parece mais provável. Além disso, o fato de muitas empresas atribuírem ao próprio acidentado a responsabilidade de entrega 
da CAT, na agência local do INSS, pode associar-se ao extravio ou nãoentrega desses documentos.

Por outro lado, o fato de a maioria das empresas não ter investigado ou ter investigado apenas parte dos acidentes ocorridos revela, em primeiro lugar, o desrespeito, por parte de empresas do município, às determinações legais firmadas nas Normas Regulamentadoras $n^{\circ} 5$ (NR 5) ou 18 (NR 18), do Ministério do Trabalho. Além disso, a inexistência de investigação contraria tendência observada na literatura, no sentido de extensão dessa prática, inclusive para incidentes ou eventos sem vítimas, reconhecidos como fontes de informação importantes para o aprimoramento das práticas de prevenção adotadas nas empresas (Carter e Corlett 1984; Menckel e Kullinger 1996; Hale e col. 1997).

A existência de 13 empresas não localizadas, fechadas e/ou com CIPA desativada e de 01 empresa com CIPA constituída e não incluída no Livro de Registro existente na Subdelegacia do Trabalho mostra que o sistema de registro dessas comissões, adotado pelo Ministério do Trabalho, na região, não possui mecanismos de atualização com agilidade adequada às transformações do mercado. Esse fato pode relacionar-se à existência meramente cartorial desses registros, segundo depoimento de responsável pela área ao pesquisador.

\subsection{As práticas de investigação de acidentes adotadas nas empresas}

A tabela 2 mostra a distribuição de investigações de acidentes do trabalho, segundo tipo de investigação de acidente realizada em empresas do município de Botucatu, SP, no ano de 1997.

As empresas citadas entregaram 203 cópias de investigações de acidentes do trabalho típicos, sendo $113(55,67 \%)$ baseadas no anexo 2 da NR 5, 8 (3,94\%) baseadas no modelo proposto pela ABNT, 75 (36,95\%) baseadas no método de árvores de causas e, em $7(3,45 \%)$ casos, a investigação baseou-se em roteiro desenvolvido na empresa.

A investigação baseada no anexo 2 da NR 5 e a baseada no modelo proposto pela ABNT mostram semelhanças, diferindo, por exemplo, pelo fato de essa segunda 
incluir descrição de categorias, como "agente" do acidente, "acidente tipo", ou de esquemas propostos para representação de parte do corpo atingida. Juntas, essas duas formas totalizaram 121 investigações, correspondendo a cerca de 59\% das análises usadas. Das 75 investigações baseadas no "método ADC", 71 foram realizadas em empresa de grande porte que fabrica aglomerados de madeira. Optou-se pelo uso de aspas na referência ao método ADC porque a análise das investigações apresentadas evidenciou desrespeito sistemático tanto a recomendações como a regras do método, em todas as etapas da análise: da coleta de dados à exploração dos acidentes. Os achados das análises serão discutidos adiante.

Tabela 2. Número de investigações de acidentes do trabalho, segundo tipo de investigação de acidente realizada em empresas. Botucatu, SP, 1997.

\begin{tabular}{|c|c|c|}
\hline \multirow{2}{*}{ Tipo de investigação feita na empresa } & \multicolumn{2}{|c|}{ Acidentes } \\
\hline & Número & $\%$ \\
\hline MTb / MTb modificado (Anexo 2 / NR 5) & 113 & 55,67 \\
\hline ABNT / ABNT modificada & 8 & 3,94 \\
\hline ADC / ADC modificada & 75 & 36,95 \\
\hline Outros (modelo desenvolvido na empresa) & 7 & 3,45 \\
\hline & 203 & 100 \\
\hline
\end{tabular}

A tabela 3 mostra a distribuição de acidentados, segundo faixa etária. Dos 203 acidentados, 157 (77,34\%) eram jovens com idade variando de 18 a 40 anos de idade. Em $41(20,20 \%)$ casos, a idade do acidentado esteve entre 41 e 60 anos de idade. Em apenas 2 casos, a idade da vítima era inferior a 18 anos, e, em 3 casos, não foi possível obter a informação. A idade média do acidentado foi 31,8 anos.

A tabela 4 mostra a distribuição dos acidentes, segundo a causa externa dos mesmos. Os grupos de causas mais freqüentes foram: impacto por objeto lançado, projetado ou em queda, em 44 (21,67\%) acidentes; contato com outras máquinas e as não especificadas, em 36 (17,73\%); contato com ferramentas manuais sem motor, em 26 (12,81\%); apertado, colhido, comprimido ou esmagado dentro de ou entre objetos, em 25 (12,32\%); impacto acidental, ativo ou passivo, causado por outros objetos, em 22 (10,84\%); quedas, em 15 (7,39\%); excesso de exercícios e movimentos vigorosos ou repetitivos, em 11 (5,42\%) acidentes. 
Tabela 3. Número de acidentados do trabalho, segundo faixa etária, em acidentes investigados em empresas. Botucatu, SP, 1997.

\begin{tabular}{|c|c|c|}
\hline \multirow{2}{*}{ Faixa etária } & \multicolumn{2}{|c|}{ Acidentes } \\
\hline & Número & $\%$ \\
\hline Menor de 18 anos & 02 & 0,99 \\
\hline 18 a 30 anos & 104 & 51,23 \\
\hline 31 a 40 & 53 & 26,11 \\
\hline 41 a 60 & 41 & 20,20 \\
\hline Sem informação & 03 & 1,48 \\
\hline & 203 & 100 \\
\hline
\end{tabular}

A tabela 5 mostra distribuição de palavras, expressões ou grupo de expressões referentes a comportamentos do acidentado, usadas nas descrições dos acidentes, elaboradas pelas empresas estudadas e registradas no campo destinado à descrição do AT. Portanto, não se referem às conclusões da investigação conduzida pela empresa. Em 164 das 211 investigações, não foram usadas expressões interpretadas como atribuidoras de causa ou culpa ao acidentado. Nos demais 39 $(19,21 \%$ ou 39/203) casos em que elas foram usadas, houve registro de 47 expressões. Descuido, falta de atenção ou de cuidado, erro, imprudência, improvisação, foram usadas 22 vezes. Atribuição a outras faltas ocorreu 8 vezes e falta de uso de EPI foi registrada 6 vezes. Operação ou posição incorreta, pressa do acidentado, predisposição do acidentado e fora de função normal apareceram, respectivamente, 4, 4, 2 e 1 vezes.

Esse achado mostra que, em quase $80 \%$ dos casos, os responsáveis pela condução das investigações de acidentes e/ou do preenchimento dos instrumentos a elas destinados, nas empresas investigadas, evitaram o uso desse tipo de palavras e/ou expressões, nos campos destinados à descrição do evento. O material didático distribuído a membros de CIPA de uma empresa metalúrgica do município que entregou fichas de investigações de 59 acidentes ocorridos em 1997 recomenda, expressamente, a não-utilização desse tipo de palavras ou expressões. Outro fator que poderia estar influenciando esse resultado seria a atuação de integrantes do Programa de Saúde do Trabalhador de Botucatu que, desde o início da década de 1990, denunciam essa prática em palestras, cursos, visitas a empresas, boletins 
informativos, publicações (Binder e col. 1994; Binder e col. 1997) e outras ações desenvolvidas na região.

Tabela 4. Acidentes do trabalho investigados em empresas de Botucatu, SP, segundo causa externa. Botucatu, SP, 1997.

\begin{tabular}{|c|c|c|}
\hline \multirow{2}{*}{ Causa externa } & \multicolumn{2}{|c|}{ Acidentes } \\
\hline & Número & $\%$ \\
\hline $\begin{array}{l}\text { V48. - Ocupante de um automóvel traumatizado em acidente de } \\
\text { transporte (sem colisão) }\end{array}$ & 2 & 0,99 \\
\hline W00.- a W19 - Quedas & 15 & 7,39 \\
\hline W20.- Impacto por objeto lançado, projetado ou em queda & 44 & 21,67 \\
\hline $\begin{array}{l}\text { W22.- Impacto acidental, ativo ou passivo, causado por outros } \\
\text { objetos }\end{array}$ & 22 & 10,84 \\
\hline $\begin{array}{l}\text { W23.- Apertado, colhido, comprimido ou esmagado dentro de ou } \\
\text { entre objetos }\end{array}$ & 25 & 12,32 \\
\hline W26.- Contato com faca, espada e punhal & 2 & 0,99 \\
\hline W27.- Contato com ferramentas manuais sem motor & 26 & 12,81 \\
\hline $\begin{array}{l}\text { W29.- Contato com outros utensílios manuais e aparelhos } \\
\text { domésticos com motor }\end{array}$ & 6 & 2,96 \\
\hline W31.- Contato com outras máquinas e com as não especificadas & 36 & 17,73 \\
\hline W41.- Exposição a um jato de alta pressão & 1 & 0,49 \\
\hline $\begin{array}{l}\text { W44.- Penetração de corpo estranho no ou através de olho ou } \\
\text { orifício natural }\end{array}$ & 6 & 2,96 \\
\hline $\begin{array}{l}\text { W45.- Penetração de corpo estranho ou objeto estranho através de } \\
\text { pele }\end{array}$ & 1 & 0,49 \\
\hline $\begin{array}{l}\text { W89.- Exposição a fontes luminosas artificiais visíveis ou à luz } \\
\text { ultravioleta }\end{array}$ & 1 & 0,49 \\
\hline X09.- Exposição a tipo não especificado de fumos, fogo ou chamas & 1 & 0,49 \\
\hline X12.- Contato com outros líquidos quentes & 1 & 0,49 \\
\hline X17.- Contato com motores, máquinas e ferramentas quentes & 2 & 0,99 \\
\hline $\begin{array}{l}\text { X36.- Vítima de avalanche, desabamento de terra e outros } \\
\text { movimentos da superfície terrestre }\end{array}$ & 1 & 0,49 \\
\hline X50.- Excesso de exercícios e movimentos vigorosos ou repetitivos & 11 & 5,42 \\
\hline Total & 203 & 100 \\
\hline
\end{tabular}

O fato de, em cerca de $20 \%$ das investigações, a própria descrição do evento já incluir esse tipo de palavras ou expressões não deve ser menosprezado, pois revela julgamentos negativos em relação a supostos comportamentos do acidentado, em etapa da investigação que deveria estar voltada para a reconstituição do evento.

Em nenhum dos 203 acidentes foram encontradas palavras ou expressões que implicassem atribuição de sua ocorrência ao azar ou má sorte do trabalhador, à vontade divina, a uma fatalidade ou algo semelhante. Esse achado corresponde ao 
esperado em registro de investigação, uma vez que o instrumento adotado não explora e nem registra as opiniões dos trabalhadores acerca de sua visão sobre as causas de acidentes.

Tabela 5. Palavras, expressões ou grupo de expressões que atribuem causa e culpa de acidente ao acidentado e número de vezes que foram encontradas na análise de campos usados para designar a descrição de acidente em instrumentos de investigação adotados em empresas. Botucatu, São Paulo, 1997.

\begin{tabular}{lc}
\hline \multicolumn{1}{c}{ Palavras, expressões ou grupos de expressões } & Número \\
\hline Descuido, falta de atenção ou de cuidado, erro, imprudência, improvisação & 22 \\
Atribuição a outras faltas & 8 \\
Falta de uso de EPI & 6 \\
Operação ou posição incorreta & 4 \\
Pressa do acidentado & 4 \\
Predisposição do acidentado & 2 \\
Fora de função normal & 1 \\
& Subtotal \\
\hline Investigações em que não houve uso desse tipo de expressão & 164 \\
\hline
\end{tabular}

A exploração do campo "causa do acidente", existente nas fichas de investigação, mostrou que a conclusão da investigação com a classificação dos achados ou "causas" em ato inseguro e/ou condição insegura foi usada em apenas 3 (1,5\%) acidentes. Em 179 (88,2\%) casos, ela não foi usada, e, em 21 (10,3\%) eventos, o campo não foi preenchido.

A tabela 6 mostra a distribuição dos grupos de causas registradas no campo "causa apurada", nas fichas de investigações de acidentes do trabalho, realizadas em empresas de Botucatu, no ano de 1997. Dos 203 acidentes analisados, houve 7 casos em que o campo não foi preenchido e 11 em que a ficha de investigação adotada não incluía esse campo ou equivalente. Foram registradas 310 "causas", em 185 investigações de acidentes, com média de 1,68 causas por evento. No Anexo 6, apresenta-se a mesma tabela com detalhamento dos grupos. 
Tabela 6. Grupos de causas registradas no campo "causa apurada", em fichas de investigações de acidentes do trabalho, realizadas em empresas com CIPA. Botucatu, São Paulo, 1997.

\begin{tabular}{|c|c|c|}
\hline Grupos de causas apuradas & Número & $\%^{1}$ \\
\hline Comportamentos do acidentado & 126 & 40,7 \\
\hline Características ou atributos do acidentado & 32 & 10,3 \\
\hline $\begin{array}{l}\text { Condições ambientes, condições técnicas de trabalho inadequadas e falha ou } \\
\text { falta de sinalização }\end{array}$ & 63 & 20,4 \\
\hline $\begin{array}{l}\text { Exigências de tarefas habituais (esforço físico, movimentação manual de } \\
\text { cargas, tarefa manual, ferramenta manual) }\end{array}$ & 14 & 4,5 \\
\hline $\begin{array}{l}\text { Defeitos, incidente, acionamento involuntário, equipamentos com regulagens } \\
\text { ou ajustes defeituosos, incompatibilidades entre materiais, equipamentos elou } \\
\text { exigências de tarefas, recuperação manual inadequada, retirar restos em } \\
\text { motor }\end{array}$ & 25 & 8,1 \\
\hline Falhas de manutenção corretiva ou preventiva & 09 & 2,9 \\
\hline Aspectos da gestão /organização do trabalho & 31 & 10 , \\
\hline $\begin{array}{l}\text { Miscelânea (escorregão, ferramenta escapa da mão, peça cai, queda de } \\
\text { objeto sobre o corpo, combate a incêndio, retirar proteção, chuva) }\end{array}$ & 07 & 2,3 \\
\hline Outras & 3 & 1 \\
\hline Subtotal & 310 & 100 \\
\hline Campo não preenchido & 07 & - \\
\hline Não se aplica (ficha não inclui o campo) & 11 & - \\
\hline Total & 328 & \\
\hline
\end{tabular}

Em estudo anterior que abrangeu 3 grandes empresas do estado de São Paulo, Binder e col. (1997) encontraram média de 1,14 causas por acidente. A concepção paucicausal ainda é largamente predominante, e o discreto aumento pode ser explicado por casos localizados de empresas em que poucas investigações resultaram em número elevado de causas.

\footnotetext{
${ }^{1}$ Calculada com base em total de causas equivalente a $310(328-18)$
} 
Os grupos de causas relativos a "comportamentos" e "características ou atributos do acidentado" totalizaram $51 \%$ das causas apontadas. Condições de trabalho inadequadas, exigências de tarefas habituais e falhas de sinalização corresponderam a $24,9 \%$ do total de causas.

Os grupos relativos a defeitos, incidentes, acionamento involuntário, equipamentos com regulagens ou ajustes defeituosos, incompatibilidades entre materiais, equipamentos e/ou exigências de tarefas, recuperação manual inadequada, retirar restos em motor e falhas de manutenção corretiva ou preventiva atingiram $11 \%$ das causas indicadas. Aspectos da organização do trabalho, como os relacionados à gestão de pessoal, de tempos de produção, das comunicações e do planejamento de tarefas, particularmente na vigência de mudanças nas condições habituais ou cotidianas de funcionamento do sistema, alcançaram 10,1\% das causas registradas, nas investigações feitas nas empresas.

Estudo de Binder e col. (1997) referente a acidentes ocorridos em 1990, em 3 grandes empresas, duas das quais na Grande São Paulo, permite comparação com estes achados. Em 72\% dos casos, a "causa" atribuída para o acidente, naquele estudo, foi relacionada a comportamentos do acidentado. Condições ambientes e/ou condições técnicas de trabalho inadequadas, que totalizaram quase $20 \%$ das "causas apuradas" aqui, não tiveram sequer um registro naquele, o mesmo ocorrendo com aspectos da organização do trabalho, que, neste estudo, corresponderam a $10 \%$ dessas causas. Defeito de equipamento, instalação ou ferramenta apareceu em 8,39\% dos acidentes, naquele estudo, e neste, em $7,1 \%$.

Os dados apontados mostram diminuição da proporção de causas atribuídas a comportamentos do acidentado, embora elas continuem representando metade das causas apuradas. Outro achado considerado significativo é o aparecimento de $30 \%$ de “causas" não comportamentais, registradas como condições ambientes ou condições técnicas de trabalho inadequadas e como aspectos da organização do trabalho.

A distribuição dos acidentes, segundo o número de causas apuradas nas investigações, mostra 99 casos com uma causa, 56 com duas, 19 com três, sete com 4 e 4 com 5 causas. Em 18 acidentes, o campo não foi preenchido ou não existia. Nos 
casos em que houve predomínio de pequeno número de "causas", o instrumento de investigação utilizado era o anexo II da norma regulamentadora 5.

As tentativas de utilização de técnicas que resultaram em aumento do número de causas, na investigação, ocorreram em empresas de médio ou grande porte, possuidoras de serviço especializado em engenharia de segurança e medicina do trabalho (Sesmt). No entanto, mesmo para estas empresas, os bancos de dados formados a partir dos registros relativos a acidentes de maior freqüência revelam-se pobres e de pequena utilidade como fonte de subsídio às ações preventivas, conforme apontado por Kletz (1993). Deixando para discutir mais adiante a qualidade das tentativas de mudanças evidenciadas nessas empresas dotadas de Sesmt, vale destacar que os achados deste estudo, no tocante às práticas adotadas em empresas menores possuidoras de CIPA, reafirmam a atualidade do dilema apontado por Hale (1993): como desenvolver gama de ferramentas que nos auxilie a aprender com os acidentes e que possa ser usada em empresas de todos os portes: pequenas, médias e grandes, independentemente das proporções do acidente?

A tabela 7 mostra que, em 73 casos, houve tentativa de identificação de responsável pelo acidente, sendo que, em 7 (3,4\%), o acidentado foi apontado como esse responsável; em 3 (1,5\%), apontou-se o empregador, e, em outros 63, a equipe considerou que não era possível identificar um responsável. $\mathrm{Na}$ maioria dos acidentes, a equipe de investigação não adotava a prática de definir responsável.

No estudo de Binder e col. (1997), em 33,6\% dos casos, não houve informação acerca de classificação de responsabilidade. Com relação aos demais casos, verificou-se que $58,4 \%$ foram atribuídos ao acidentado ou a outro trabalhador e 6,4\% à empresa.

A diminuição observada na prática de identificação de responsável pelo acidente parece refletir a influência da crescente difusão de informações acerca de disputas judiciais, em casos de acidentes, fato que poderia ensejar preocupações ou temores entre os participantes dessas investigações. Além disso, têm crescido opiniões contrárias à definição de responsabilidades pelo AT, nas investigações desses eventos, fato revelado, inclusive, pela leitura de apostilas usadas em cursos de 
CIPA de empresas com maior freqüência de acidentes, no ano do estudo, que mostram a inclusão de recomendação explícita no sentido da não-utilização dessa classificação nas conclusões de investigações conduzidas nas mesmas. Outros fatores que poderiam contribuir nesse sentido seriam a ausência de orientações relativas ao preenchimento desse campo, na norma regulamentadora número 5, e a ausência, no município, de conflitos ou demandas jurídicas que ensejassem o uso da atribuição de responsabilidade ao acidentado como parte de estratégias de defesa adotadas por representantes de empresas.

Tabela 7. Distribuição dos acidentes investigados em empresas de Botucatu, SP, segundo tipo de conclusão encontrada no campo “Responsabilidade" pelo acidente. Botucatu, São Paulo, 1997.

\begin{tabular}{|c|c|c|}
\hline Responsabilidade & Número & $\%$ \\
\hline Acidentado & 07 & 3,4 \\
\hline Empregador & 03 & 1,5 \\
\hline Não foi possível identificar & 63 & 31,0 \\
\hline Campo não preenchido / Não usa a classificação & 127 & 62,6 \\
\hline Sem informação & 03 & 1,5 \\
\hline Total & 203 & 100 \\
\hline
\end{tabular}

A tabela 8 mostra a distribuição das "medidas propostas", registradas nas fichas de investigação dos 203 acidentes, de acordo com grupos de medidas. Excluídas 15 situações em que o campo não foi preenchido ou as informações não permitiram sua classificação, foram registradas 291 propostas, com média de 1,4 propostas por acidente, inferior à de causas apuradas, 1,68 por acidente.

Os grupos de medidas "Mudanças de comportamento do acidentado ou de colega" e "Treinamento, palestras, cursos" totalizaram 161 (55,3\% ou 161/291) recomendações. Em duas outras medidas $(0,7 \%)$, foram sugeridas normas relativas a mudanças de comportamento. A mudança mais freqüente foi a de maior atenção por parte do acidentado, na realização de sua atividade. Em 23 (7,9\% ou 23/291) casos, houve sugestão acerca do uso e/ou seleção de EPI por parte do acidentado. Somadas, têm-se $186(63,9 \%)$ medidas que se referem a mudanças de comportamento do acidentado. Desse total, apenas parte das 22 incluídas nas rubricas "Treinamento, 
palestras, cursos" e "Introdução de mudanças pela adoção de normas" refere-se a sugestões relativas a modos operacionais ou formas de realização da atividade. A maioria das medidas citadas refere-se a sugestões genéricas de prestar mais atenção, melhorar treinamentos ou formação, sem especificação de objetivos e/ou conteúdos. As medidas relativas a EPI não especificaram aspectos a serem observados ou enfatizados nas práticas das empresas. Dirigiam-se ao acidentado, indicando que a forma de uso ou o estado de conservação do EPI contribuíra no acidente, e que ele deveria adotar providências para evitar a repetição daquele fato.

Tabela 8. Distribuição das medidas propostas em 203 investigações de acidentes realizadas em empresas. Botucatu, São Paulo, 1997.

\begin{tabular}{lcc}
\hline \multicolumn{1}{c}{ Grupos de medidas propostas } & Número & \% \\
\hline Mudanças de comportamento (genéricas) ${ }^{2}$ & 139 & 45,4 \\
Treinamentos, palestras, cursos & 22 & 7,2 \\
Introdução de mudanças pela adoção de normas & 2 & 0,7 \\
Equipamentos de proteção individual & 23 & 7,5 \\
Correção técnica e/ou ambiental & 32 & 10,5 \\
Manutenção, avaliações, testes, inspeções ... & 13 & 4,2 \\
Ordem, limpeza, prevenção de quedas em mesmo nível ou & 27 & 8,8 \\
na movimentação manual de cargas & 3 & 1,0 \\
Sinalização, rotulagem, travamentos ... & 15 & 4,9 \\
Estudar, avaliar, verificar (referido genericamente) & 8 & 2,6 \\
Medidas relativas à organização do trabalho & 2 & 0,7 \\
Mudanças em práticas de segurança & 2 & 0,7 \\
Descrição ou registro de problemas ${ }^{3}$ & 3 & 1,0 \\
Outras & 15 & 4,9 \\
Campo não preenchido / informação insuficiente & 306 & 100 \\
\hline
\end{tabular}

A proporção $(60,8 \%)$ de medidas propostas referentes a mudanças de comportamentos, registradas nos 4 primeiros grupos da tabela 8 , ultrapassa, em cerca de $11 \%$, a proporção de causas apuradas apresentadas na tabela 6 , referindo-se a

\footnotetext{
${ }^{2}$ Inclui: orientar, conscientizar, insistir em maior atenção, referências a proibições, etc.

${ }^{3}$ Não inclui propostas de prevenção.
} 
"comportamentos do acidentado" e "características ou atributos do acidentado". Neste estudo, a proporção de medidas dirigidas a mudanças de comportamentos dos acidentados foi inferior à observada no estudo de Binder, Azevedo e Almeida (1997), que atingiu $72,9 \%$ das propostas. Essa diferença mantém-se, praticamente, inalterada, quando o cálculo é refeito, excluindo-se, nos dois estudos, os casos em que o campo não foi preenchido, mostrava-se sem informação e/ou incluía aspecto que não correspondia à medida ou recomendação de prevenção, ou seja, o grupo “descrição ou registro de problema”, presente na tabela 8.

Segundo Levanthal e col. (1965), o uso de orientações específicas para a ação seria condição necessária, mas não suficiente, para a implementação de mudanças de comportamento com vistas à prevenção de acidentes. As medidas propostas nas empresas estudadas foram genéricas e semelhantes às já observadas em estudo de Binder e col. (1997).

Carpentier-Roy e col. (1998) afirmam que a existência de uma "cultura do ofício" dos trabalhadores, reconhecida pelos integrantes dos níveis hierárquicos superiores da empresa, seria favorecida por iniciativas de formação específica e poderia estimular a condição de sentir-se pertencente e integrado ao grupo dos trabalhadores à empresa. Essa condição também foi apontada por Dejours (1993a, 1997) como de grande importância para a confiabilidade dos sistemas. A abordagem preventiva proposta nas empresas estudadas perde a oportunidade de utilizar o processo de investigações de acidentes para o aprendizado organizacional, através da exploração desse sentimento de "ser parte" de um grupo.

O grupo de medidas "Correção técnica e/ou ambiental" apareceu 32 (10,5\%) vezes. Os grupos "Ordem, limpeza, prevenção de quedas em mesmo nível ou na movimentação manual de cargas" e "Sinalização, rotulagem, travamentos..." apareceram, respectivamente, $27(8,8 \%)$ e $3(1,0 \%)$ vezes. Assim, esse conjunto de medidas que, em geral, refere-se a correções de aspectos presentes de modo permanente, na situação de trabalho, correspondeu a 19,3\% das medidas propostas. Esta proporção foi inferior à de causas apuradas (tabela 6) para os grupos "condições ambientes e/ou condições técnicas de trabalho inadequadas", "exigências de tarefas habituais" (inclui esforço físico, movimentação manual de cargas, etc.) e "falha ou 
falta de sinalização", que totalizaram 24,9\%. Esses dados mostram que, em cerca de $80 \%$ das vezes que se apontou como causa do AT um fator desse grupo, houve, pelo menos, uma recomendação de medida de prevenção relativa à sua correção. No entanto, em cerca de $20 \%$ dos casos em que esse tipo de causa chegou a ser apontado na investigação, não houve indicação de providências destinadas à sua correção.

A proporção de medidas propostas incluídas nesse grupo (19,3\%) foi ligeiramente inferior à proporção de medidas semelhantes $(22,2 \%)$, encontradas por Binder e col. (1997), para "melhorar equipamento, mudar processo, inspecionar periodicamente, eliminar condições inseguras, melhorar sinalização”.

Por sua vez, os grupos de medidas relativas à organização do trabalho, com 8 $(2,6 \%)$ medidas, manutenção, avaliações, testes e/ou inspeções, com 13 (4,2\%) medidas, e mudanças em práticas de segurança, com duas $(0,7 \%)$ medidas, totalizaram $23(7,5, \%)$ registros.

As causas apuradas (tabela 6) relativas a aspectos da organização do trabalho (31 'causas'- 10\%), seja relacionados à gestão de pessoal, de tempos de produção, das comunicações e do planejamento de tarefas, particularmente na vigência de mudanças nas condições habituais ou cotidianas de funcionamento do sistema, correspondem a 3,8 vezes as medidas corretivas do mesmo grupo (8 medidas $2,6 \%$ ). Isso significa que, embora esse tipo de fator causal tenha sido identificado em $10 \%$ do total de causas apontadas nas investigações, em cerca de $75 \%$ desses casos, sua existência foi desconsiderada, por ocasião da abordagem preventiva, sugerida na investigação conduzida na empresa.

Por sua vez, o grupo de propostas "Manutenção, avaliações, testes e/ou inspeções" correspondeu a 4,2\% do total de medidas, enquanto a proporção de causas apuradas relativas a "defeitos, incidentes, acionamento involuntário, equipamentos com regulagens ou ajustes defeituosos [...]" e "falhas de manutenção corretiva ou preventiva" totalizou $9,4 \%$. O dado indica que, em cerca de $55 \%$ das vezes em que esse tipo de causa foi apontado na investigação, sua existência foi desconsiderada, por ocasião da abordagem preventiva, sugerida na empresa. 
O grupo "Estudar, avaliar, verificar" teve 15 (4,9\%) registros, correspondendo, em geral, a proposições genéricas que postergam a adoção efetiva de medidas de correção dos fatores de acidentes.

Não houve sugestão de medidas classificadas como pertencentes ao grupo "Seleção de candidatos", cuja presença foi buscada de modo ativo em todas as investigações.

A observação do conjunto dos achados descritos nas investigações feitas nas empresas estudadas permite destacar os seguintes aspectos:

- As palavras e expressões que atribuíam culpa ao acidentado foram usadas nas descrições de "apenas" 39 (19,2\%) dos 203 acidentes.

- Os grupos de causas externas que indicam a participação de "ferramenta manual motorizada" ou "máquinas" no acidente apareceram em 42 acidentes, enquanto a indicação de correção técnica e/ou ambiental foi apontada em 32 casos. Em outros 13 casos, foram sugeridas medidas relacionadas a "manutenção, testes, etc.", que, em sua maioria, recomendavam melhorar ou mudar prática de manutenção, sem qualquer tipo de especificação de objetivo, problema a ser corrigido ou medida a ser adotada.

- Os grupos de causas envolvendo "quedas", "choque contra objeto", ser "atingido por objeto", ser "apertado, colhido entre ou esmagado dentro ou entre objetos" e/ou "excesso de exercícios e movimentos vigorosos ou repetitivos" foram apontados em 117 acidentes, e as medidas propostas relativas a "Ordem, limpeza, prevenção de quedas em mesmo nível ou na movimentação manual de cargas", "sinalização, rotulagem, travamentos..." foram referidas em apenas 30 casos. Parte das referências a EPI, em outros 23 acidentes, pode referir-se a alguns desses casos, por exemplo, sugestões de uso de luvas de cano longo, em situações em que o braço é atingido por um objeto, porém essas sugestões não abordam a situação que deu origem ao acidente. 
- grupo de medidas propostas relativas a mudanças de comportamento do acidentado foi o único grupo de causas registradas em maior proporção que a de causas apuradas relativas ao mesmo grupo.

- grupo de medidas propostas relativas a "correções técnicas e/ou ambientais" e a "ordem, limpeza, prevenção de quedas em mesmo nível ou na movimentação manual de cargas" aparece em cerca de $80 \%$ dos casos em que causa desse mesmo grupo é apontada na investigação.

- As causas apuradas relativas à "organização do trabalho (gestão de pessoal, pressões de tempos, falhas de comunicação, etc.)" e a "defeitos, incidentes [...]" e "falhas de manutenção" correspondem a pequena proporção do total de causas apuradas e são desconsideradas em cerca de $80 \%$ e $55 \%$ das vezes, respectivamente, por ocasião da elaboração de propostas de prevenção.

Assim, um aspecto que chama a atenção, quando se observam os dados acima, é a pobreza das recomendações. Se a análise das descrições de acidentes e de suas causas apuradas ou conclusões já revela falhas, a comparação de seus achados com aqueles das recomendações de prevenção revela quadro ainda mais precário: fatores causais registrados como tal deixam de ser considerados em proporção que aumenta quando se trata de aspectos ligados à gestão da produção/organização do trabalho, mas que não é desprezível se o fator causal é de natureza técnica ou ambiental. O predomínio de medidas genéricas ligadas a comportamentos e/ou características de acidentados, nas recomendações, complementa o quadro de precariedade das investigações de acidentes e representa fato adicional no processo de atribuição de causa, culpa e responsabilidade às vítimas de acidentes.

Essa precariedade torna-se mais grave devido ao divórcio que revela existir entre as análises de acidentes e do trabalho em sua totalidade. No entanto, esses achados mostram que o mesmo divórcio existe, tanto em relação à perspectiva do aprendizado organizacional, desenvolvida por estudiosos de comportamentos face ao perigo, quanto à da análise da atividade desenvolvida pela corrente francesa da 
Ergonomia. Indo mais além, verifica-se que ele se mantém, inclusive, em relação à noção de tarefa adotada, no método de árvore de causas.

Por que as condições organizacionais são as mais negligenciadas na exploração das análises conduzidas nas empresas? Este estudo não explorou essa questão com os atores responsáveis pelas análises, porém é possível formular algumas hipóteses a esse respeito.

As referências à organização do trabalho das empresas, obtidas nas investigações de acidentes, aparecem de modo isolado, não explorado de forma a ensejar um diagnóstico da origem de acidentes que propicie a identificação de pontos de convergência ou problemas cuja abordagem possa mostrar-se de interesse da segurança e dos gestores da produção. Nessas condições, torna-se quase impossível a tarefa de sensibilização das empresas para a adoção de abordagem que integre a problemática dos acidentes com aquela do seu modelo de eficácia de produção.

Nas empresas estudadas, não há sequer a adoção de estratégias de prevenção baseadas em cada um dos aspectos identificados. Por exemplo, pode-se evidenciar que alguns acidentes ocorrem durante a realização de horas extras, no entanto não há registros de recomendações de prevenção formuladas para a correção desse fator. Ele é simplesmente "esquecido". A abordagem proposta pelos criadores do método de árvore de causas indica que a prevenção, nessas situações, exige que a investigação esclareça, tanto as mudanças no conteúdo do trabalho que está sendo realizado nesse período, quanto as condições do sistema que deram origem à decisão de lançar mão das horas extraordinárias de trabalho.

A identificação de aspectos da organização do trabalho na análise de acidentes constitui oportunidade perdida para o desencadeamento de ações que levem ao diagnóstico da complexidade da situação que está na origem dos acidentes. $\mathrm{O}$ método $\mathrm{ADC}$, quando adequadamente utilizado, permite identificar pontos críticos da atividade desenvolvida na empresa, momentos de gestão da variabilidade temporal da produção, de gestão de demandas que ultrapassam as capacidades de recursos técnicos e humanos existentes no sistema, gestão de perturbações da atividade, entre outros que ensejam a adoção de estratégias de recuperação que 
podem fracassar e, direta ou indiretamente, levar ao acidente. Sua identificação deve gerar solicitações de análises complementares e medidas de prevenção.

É verdade que, em alguns casos, a investigação revela a utilização de estratégias claramente inaceitáveis do ponto de vista da segurança. Neste estudo, um dos exemplos deste tipo de situações é o remanejamento improvisado de trabalhadores para a operação de máquinas perigosas. Trata-se de prática que sugere a existência de concepção de polivalência equivalente a: qualquer um faz qualquer coisa, de qualquer jeito/com quaisquer meios.

Em seu conjunto, esses achados indicam que, nas empresas estudadas, a análise de acidentes é vivenciada como formalidade burocrática e como instrumento de controle do potencial de questionamento que poderia advir desse processo.

\subsection{Análise das árvores de causas elaboradas por 4 empresas de} Botucatu

Conforme apontado anteriormente, em 75 casos profissionais de 4 das empresas estudadas, elaboraram-se análises tentando utilizar o método de árvore de causas. Os registros relativos a essas investigações foram analisados da seguinte maneira:

a) Checagem do uso das categorias de análise do método.

b) Checagem das recomendações relativas ao uso da linguagem, definição e denominação dos fatores de acidente.

c) Checagem da montagem das árvores: primeiro fator registrado, desenho das relações, relação lógica entre os fatos, "regras de parada", opinião geral acerca da organização da árvore, procurando selecionar alguns casos para comentários à parte, particularmente quando o esquema montado apresentava exemplos flagrantes de desrespeito às regras do método. 
d) Checagem da exploração das árvores: medidas de prevenção, recomendações, sua coerência com fatores de acidente registrados na investigação, tipo de acidente e indicação técnica de uso do método.

e) A título exploratório, no caso da empresa que procurou adotar o método em 71 acidentes, procurou-se identificar acidentes que mostravam fatores assemelhados e aspectos de sua exploração.

\subsubsection{O uso das categorias de análise do método}

A Tabela 9 mostra o número de análises com o método, por empresa, e aspectos do uso de regras do método ADC, nas análises de acidentes com o método entregues pelas 4 empresas do município de Botucatu, referentes a acidentes ocorridos e investigados no ano de 1997. Verifica-se que, das 4 empresas que tentaram usar o método de árvore de causas, uma montou esquemas para 71 acidentes investigados. Em outra, o método foi usado em 2 casos e, nas outras duas, houve elaboração de árvore para 1 dos acidentes registrados, totalizando 75 árvores.

Tabela 9. Árvores de causas, segundo empresas, e uso de regras do método. Botucatu, SP. 1997.

\begin{tabular}{|c|c|c|c|}
\hline \multirow{2}{*}{ Empresas } & \multicolumn{3}{|c|}{$\begin{array}{l}\text { Número de árvores por empresa e segundo uso de } \\
\text { regras do método }\end{array}$} \\
\hline & $\mathrm{N}^{\circ}$ de árvores & $\begin{array}{l}\text { Uso categorias } \\
\text { de análise }{ }^{4}\end{array}$ & $\begin{array}{c}\text { Classificação de } \\
\text { habitualidade }\end{array}$ \\
\hline A (Metalúrgica) & 01 & 01 & 01 \\
\hline B (Metalúrgica) & 02 & 02 & 02 \\
\hline $\begin{array}{l}\text { C (Distribuição de } \\
\text { energia) }\end{array}$ & 01 & 01 & 01 \\
\hline $\begin{array}{l}\text { D (Aglomerados de } \\
\text { madeira) }\end{array}$ & 71 & - & 46 \\
\hline Total & 75 & 04 & 50 \\
\hline
\end{tabular}

Do exposto, verifica-se que, apenas no caso da empresa D, é possível avaliarse o domínio da técnica por parte das equipes de investigação. Nas demais, o pequeno número de acidentes inviabiliza qualquer tipo de generalização, embora seja possível fazer algumas indicações acerca das árvores analisadas.

\footnotetext{
${ }^{4}$ Conceitos de atividade e seus componentes: indivíduo (I), tarefa (T), material (M) e meio de trabalho (MT).
} 
As categorias de análise do método, a saber, a atividade dividida em seus componentes, indivíduo, tarefa, material e meio de trabalho, foram empregadas apenas em 4 investigações, realizadas nas empresas A, B e C, que elaboraram árvores para no máximo 2 dos acidentes nelas registrados. A empresa $\mathrm{D}$, a única a tentar utilizar o método em todos os casos que investigou, não usou essas categorias. A análise posterior das árvores elaboradas nas empresas $\mathrm{A}, \mathrm{B}$ e $\mathrm{C}$ revelou falhas no uso dessas categorias.

A classificação de fatores do acidente, segundo a sua habitualidade, fatores variações ou fatores habituais, considerada fundamental pelos criadores do método, foi usada em 50 dos 75 acidentes em que houve elaboração de árvore, deixando de ser usada em $25(33,3 \%)$ acidentes investigados na empresa D.

A análise dos $50(66,6 \%)$ esquemas em que houve a classificação dos fatos mostra indícios de falhas no seu uso. Afinal, em 34 (68\% ou 34/50) casos, houve registro de apenas 1 fato habitual e, em outros $6(12 \%)$ casos, esse número foi 2. Esse dado por si só sugere que a etapa de coleta de dados das investigações não esteja descrevendo de modo adequado os fatores habituais participantes dos AT. Também é possível que fatos habituais (representados por quadrado) tenham sido registrados no desenho como variações (representados por círculo), sendo a identificação desse tipo de erro dificultada por dois aspectos: a) a inexistência, nas 71 investigações feitas na empresa D, de lista de fatos classificados segundo componente da atividade e habitualidade; b) o fato de este estudo basear-se na leitura de registros de investigações feitos e entregues por representantes da empresa, não incluindo trabalho de reconstrução das investigações já realizadas.

Em estudo anterior, Almeida (1996) encontrou 44\% de fatores classificados como habituais e $47 \%$ de variações. Por sua vez, analisando 21 acidentes ocorridos nos anos de 92 e 93, em uma empresa de Botucatu, Binder e col. (1998) encontraram, respectivamente, $54,24 \%$ e $45,15 \%$ de variações e fatos habituais. Nesses dois estudos, a elevada proporção de fatos habituais foi considerada como indicação da presença permanente de más condições de trabalho. 
A existência de falhas no uso das categorias do método pode ter reflexos na exploração das árvores, particularmente na abordagem de aspectos da origem de fatores de acidentes, cuja identificação como variação poderia facilitar ao investigador corrigir a omissão em que estaria incorrendo. A obediência à recomendação de priorizar a investigação de variações e de buscar as "causas das causas" tende a conduzir essas análises até a identificação de fatores com participação nas origens remotas ou tardias desses eventos. Pode-se considerar que o uso sistemático da classificação poderia, no mínimo, suscitar discussões acerca do papel desses fatores, na origem dos acidentes. Aliás, a exploração desses antecedentes é estimulada em cursos e na literatura sobre o método e/ou referente à prevenção de acidentes (Binder 1997; Binder e col. 1998; Binder e Almeida 1999; Llory 1996; Paté-Cornell 1993).

A não-utilização dessas categorias também pode trazer prejuízos, particularmente para investigadores com pouca experiência no uso do método, na etapa de coleta de dados. Como se sabe, não existe um roteiro ou questionário a ser usado na investigação ADC. Deve-se tão somente verificar se houve variações em componentes da atividade, investigar suas origens e complementar a investigação com a checagem de eventual contribuição de fator habitual ligada aos componentes da atividade. O uso sistemático da classificação auxilia a equipe a checar todos os componentes, evitando lacunas na sua investigação.

Investigadores experientes podem abrir mão do uso da classificação de fatores segundo componente da atividade, simplificando e agilizando o uso do método, sem riscos de descaracterizá-lo. Esse não parece ser o caso das empresas aqui estudadas, em que a não-utilização das categorias parece decorrer de falta de domínio das regras do método por parte dos investigadores, conforme se verá ao longo dessa descrição.

Por sua vez, o abandono do conceito de variação fere princípio fundamental do método. Os seus criadores destacam a importância deste conceito, seja como fio condutor da coleta de dados, seja como elemento orientador da exploração da árvore. Leplat (1985) adota-o na própria definição de investigação de acidente, que 
consistiria em identificar tanto o que mudou em um sistema quanto as condições desse sistema que teriam permitido a origem dessas mudanças.

A Tabela 10 mostra que $77 \%$ (57) das árvores tiveram até 10 fatores. O número médio de fatores foi 9, com mínimo de 5, em 4 árvores, e máximo de 21, em um acidente da empresa B. Em 20\% (15) dos esquemas, o número de fatores variou entre 11 e 15 e, em apenas 2,7\% (2) casos, ambos da empresa B, o número de fatos foi superior a 15 .

Tabela 10 Árvores de causas e porcentagem de árvores, segundo número de fatores por árvore. Botucatu, SP. 1999.

\begin{tabular}{|c|c|c|}
\hline$N^{o}$ de fatores & $\mathrm{N}^{0}$ de árvores & Porcentagem \\
\hline Até 10 & 57 & $77,0 \%$ \\
\hline 11 a 15 & 15 & $20.3 \%$ \\
\hline 16 a 21 & 2 & $2,7 \%$ \\
\hline Total & 74 & 100,0 \\
\hline
\end{tabular}

Não foram encontrados estudos que descrevessem dados semelhantes para comparação. Em estudo de 42 acidentes graves ocorridos em empresas industriais de Botucatu, Almeida (1996) encontrou média de 19 fatores por acidente. Esse dado e a experiência do autor com o uso do método permitem afirmar que, na maioria dos casos, as análises identificaram número pequeno de fatores, até 10 , sugerindo que a investigação tenha sido interrompida de modo precoce. Esses resultados são, obviamente, explicados pelo ocorrido na empresa $\mathrm{D}$, que realizou a maioria das análises.

Segundo Kouabenan (1999a), uma das diferenças entre as investigações voltadas para a prevenção e as para a busca de culpados está no número de fatores de acidente. No segundo caso, a investigação é interrompida precocemente, como aconteceu na maioria dos acidentes acima citados. 


\subsubsection{Cuidados de linguagem, definição e denominação dos fatores} de acidente

Uma das dificuldades constantemente apontadas em relação ao uso do método ADC é a necessidade de domínio da linguagem por parte da equipe de investigação (INRS, 1993; SNCF, s/d; Binder, 1997; Binder e Almeida, 1997b). A adoção de cuidados recomendados visa facilitar a organização de fatores e a montagem da árvore e uniformizar o uso dessa técnica, diminuindo o número de diferenças evidenciadas em análises e árvores realizadas por diferentes pessoas e/ou equipes.

Em todas as 75 árvores analisadas, verificou-se desrespeito à recomendação de nomear cada fato com frase construída com a estrutura sujeito - verbo complemento (S-V-C), se necessário. O prejuízo advindo dessa prática pode ser de importância menor, uma vez que a denominação escolhida permita identificação precisa do fator e de sua participação na árvore, o que, infelizmente, não foi o que ocorreu nas árvores elaboradas nas empresas estudadas. Nelas, foram associadas outras falhas, como dois nomes para um mesmo fator, um só nome para dois ou mais fatores, nomes que não permitiam a identificação de um fato ou evento especificado, além de outras falhas. Como consequiência, diversos esquemas deixaram de ser autoexplicativos, perdendo uma de suas principais características, qual seja, a de poderem ser usados como ferramenta auxiliar na comunicação entre os setores envolvidos e como auxílio à exploração dos esquemas com vistas à prevenção.

Para melhor visualização, destacam-se, abaixo, outros problemas evidenciados no tocante a cuidados de linguagem, definição e denominação de fatores participantes de acidentes e incluídos nas respectivas árvores:

a) Em 65 (86,6\%) árvores, havia registro de nomes dados a fatores do acidente que não eram passíveis de observação e que foram classificados como: interpretações propriamente ditas, juízos de valor, referências a faltas/ausências ou negações. Em relação aos juízos de valor e interpretações, em nenhum dos casos havia referência, seja à consulta ao acidentado que permitisse considerar a participação no AT de algum fator 
individual relacionado à opinião citada, seja à técnica ou cuidado de análise que permitisse ao pesquisador identificar como o investigador chegara àquela opinião. Em 21 casos, esse tipo de problema ocorreu apenas uma vez e, nos demais, de 2 a 5 vezes.

b) Em 38 (50,6\%) árvores, houve registro de nomes genéricos, que não permitiam identificar um fato ou fator de acidente. Em 25 esquemas, isso ocorreu apenas 1 vez e, nos demais, de 2 a 4 vezes.

c) Em $20(26,6 \%)$ árvores, foram registrados nomes que correspondiam a mais de um fato, ou seja, que deveriam ter sido desmembrados em mais de um fator. Em 14 dessas árvores, isso ocorreu apenas 1 vez e, nas demais, isso ocorreu de duas a 4 vezes.

d) Em 7 (9,3\%) árvores, o mesmo fator recebeu denominações distintas, sendo incluído mais de uma vez no esquema do acidente. Em 5 casos, esse problema ocorreu apenas 1 vez e, nos outros dois, duas vezes.

O detalhamento da análise dos 4 subgrupos de fatores, agrupados como não passíveis de observação, revelou que, em 18 árvores, houve inclusão de fator cujo nome foi classificado como juízo de valor, ou seja, "descuido", "falta de atenção" ou denominação semelhante. Em 16 (88,8\% ou 16/18) desses acidentes, isso ocorreu apenas uma vez. Em 42 (56\%) esquemas, houve registro de fatores classificados como interpretações propriamente ditas, acontecendo apenas uma vez em 25 deles. Em $35(46,6 \%)$ acidentes foram registrados fatos classificados como faltas ou ausências, sendo verificado apenas uma vez em 25 deles. Por sua vez, as negações apareceram em 39 (52\%) árvores, dando-se apenas 1 vez em 21 delas e, nas demais, de duas a cinco vezes.

Nas situações citadas, desrespeita-se recomendação expressa dos autores do método, qual seja, a de que, numa análise de acidente, na fase de elaboração da árvore, devem-se descrever os fatores ou fatos presentes na situação, de tal modo que, na fase de análise ou exploração da mesma, as interpretações tenham suas origens claramente especificadas no esquema elaborado. Os exemplos a seguir 
ilustram essa regra: ao invés de considerar como fator de acidente "O Sr. X é novato (ou inexperiente)", dever-se-iam incluir fatores como "O Sr. X trabalha no setor há 3 dias", "O Sr X está em seu primeiro emprego", "A formação do Sr X consiste em observar o trabalho de colegas" ou outras que descrevessem os fatores, permitindo a interpretação de que a condição de inexperiência do Sr. X poderia ter participado, ou participou, na origem do acidente em questão.

A utilização de fatores considerados como resultantes de opiniões "a priori”, interpretações, juízos de valor ou semelhantes, já na descrição do acidente, é apontada na literatura como um dos problemas presentes em investigações de acidentes e constitui aspecto contra o qual se dá grande destaque na formação de pessoal, no uso do método ADC e em alguns textos que abordam a investigação de acidentes. Na literatura, quando essas referências incluem uso de expressões como descuido, negligência, falta de atenção, exposição desnecessária ao perigo ou outras semelhantes ou, ainda, quando a descrição enfatiza comportamentos ou ações do acidentado ou de seus colegas como "causa" do acidente, têm sido consideradas como exemplos de atribuição de causa, culpa e responsabilidade pelo acidente ao próprio acidentado ou a seus colegas (Wigglesworth 1978; Binder 1997; Binder e col. 1997; CCOHS.1998).

A somação dos erros apontados contribui para o aparecimento daquilo que, segundo informação verbal de Binder, em curso de formação desenvolvido no INRS, denomina-se "'arvore de culpados", como se pode ver nas figuras 3 e 4 , que mostram esquemas elaborados por integrantes da equipe técnica da empresa D.

A identificação desses problemas permite afirmar que os responsáveis pelo uso do método, na empresa $\mathrm{D}$, não o dominam e incorrem em falhas que podem ser consideradas graves, uma vez que implicam em desrespeito a princípios fundamentais do método. Em relação aos esquemas elaborados nas empresas A e B, foi possível identificar a presença de grande número de problemas semelhantes aos apontados, enquanto que, na empresa $\mathrm{C}$, eles estiveram presentes em pequena quantidade. 
Figura 3. Exemplo de "árvore de culpados" elaborada em empresa de Botucatu, SP., 1997.

Acidente ao amarrar pacote de chapas

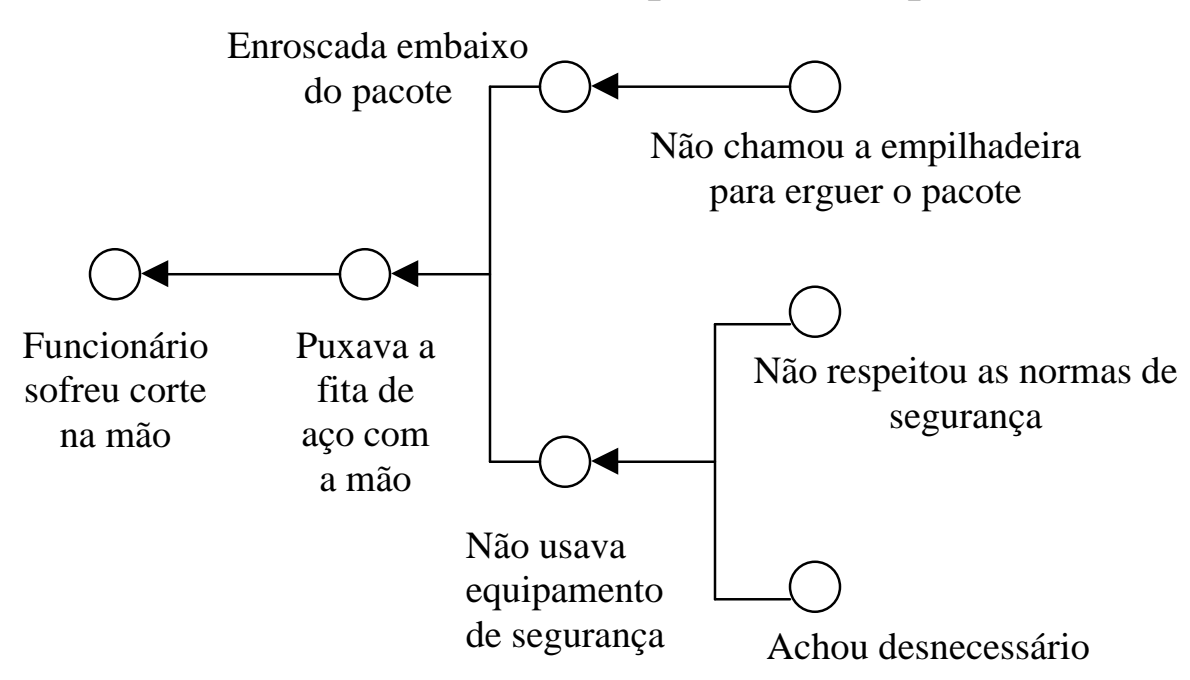

Figura 4. Exemplo de "árvore de culpados" elaborada em empresa de Botucatu, SP., 1997.

Acidente ao apagar incêndio em transportador de chapas

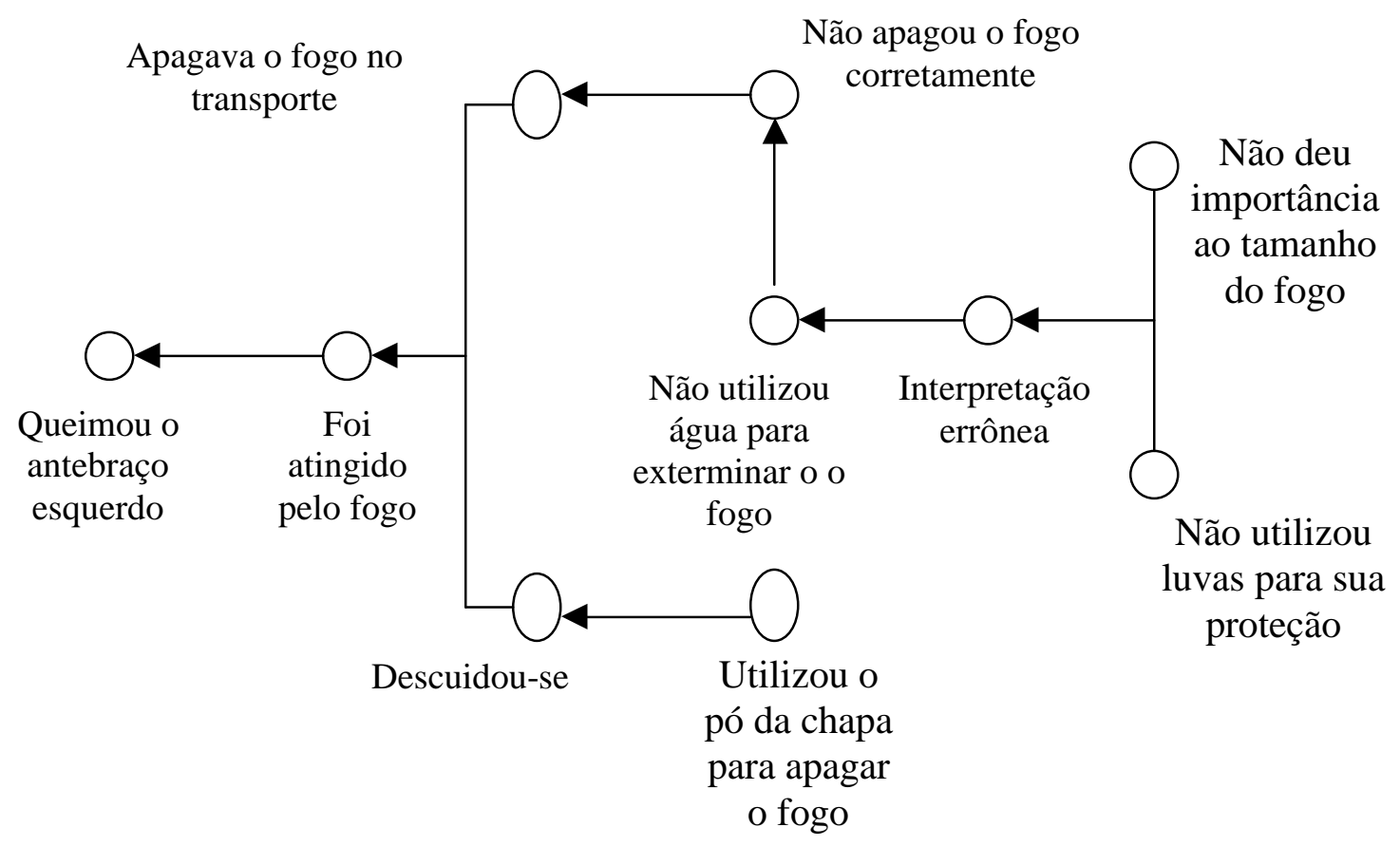




\subsubsection{Checagem da montagem das árvores}

A análise dos esquemas elaborados nas empresas foi iniciada pelo desenho ou representação dos fatores de acidente, já comentada por ocasião da descrição do uso da classificação quanto à habitualidade, continuando com checagem de aspectos do desenho propriamente dito, como por exemplo:

a) sentido dado ao esquema (da direita para a esquerda do leitor, conforme adotado pelos criadores do método ou outro: da esquerda para a direita? de cima para baixo? de baixo para cima?).

b) Desenhos das configurações ou relações entre fatos incluídas no esquema: cadeias, conjunções, disjunções, sobredeterminações ou outras, ou seja, relações diferentes das apresentadas pelos criadores do método.

c) Início do desenho pela lesão ou último fato identificado na descrição do acidente.

d) Presença de erro de lógica no desenho, ou seja, desenho incluindo variações participando na origem de fatos habituais ou variações originadas apenas em fatos habituais.

e) Organização do desenho - verifica-se aspecto geral do desenho, como o início do desenho, o sentido das relações, as setas indicativas do sentido das relações e o desenho das configurações.

A tabela 11 mostra o número de árvores de causas, segundo presença ou não de erro no seu desenho e tipo de erro representado no esquema. Verifica-se que, em relação ao início do esquema pela representação da lesão, em apenas $4(5,3 \%)$ casos, o esquema apresentou erro. Embora pequeno, esse percentual aponta a existência de um tipo de erro cuja presença indica, praticamente, total desconhecimento das regras do método.

Em 73 (97,3\%) árvores, o desenho não respeitava o sentido da direita para a esquerda, padronizado pelos criadores do método. As $71(94,6 \%)$ árvores montadas 
na empresa "D" o foram da esquerda para a direita, e 2 árvores da empresa B o foram de cima para baixo. O desrespeito à recomendação dos criadores do método não foi alvo de nenhuma explicação por parte dos técnicos das empresas citadas. Essa prática, em si, não tem nenhuma implicação para a análise do acidente, porém quebra a uniformidade de apresentação dos esquemas que o respeito à recomendação preservaria.

Tabela 11. Árvores de causas, segundo tipo de erros representados no desenho. Botucatu, SP. 1999.

\begin{tabular}{lccccc}
\hline \multirow{2}{*}{ Erro } & \multicolumn{5}{c}{ Tipos de erros representados na árvore ou desenho } \\
\cline { 2 - 6 } & $\begin{array}{c}\text { Início pela } \\
\text { lesão }\end{array}$ & $\begin{array}{c}\text { Sentido do } \\
\text { desenho }\end{array}$ & $\begin{array}{c}\text { Setas nas } \\
\text { relações }\end{array}$ & $\begin{array}{c}\text { Erro de } \\
\text { lógica }\end{array}$ & Organização \\
\hline Sim & 4 & 73 & 32 & 35 & 41 \\
Não & 71 & 2 & 43 & 15 & 34 \\
NC & - & - & - & 25 & - \\
\hline \multicolumn{1}{c}{ Total } & 75 & 75 & 75 & 75 & 75 \\
\hline
\end{tabular}

Vale registrar que, em sua última edição, a "Encyclopaedia of Occupational Health and Safety", publicada pela Organização Internacional do Trabalho, no verbete dedicado ao método, apresenta esquema desenhado de cima para baixo (Monteau 1998). Segundo informação verbal do autor ${ }^{5}$ do verbete, os editores da publicação modificaram o esquema original por ele encaminhado, explicando-se, dessa maneira, esse desrespeito às recomendações anteriormente divulgadas.

Em 32 (42,6\%) árvores, houve ausência de inclusão de setas indicativas do sentido da relação entre os fatos, sendo total em 13 casos e parcial em 19 esquemas. Nos desenhos organizados, a ausência das setas nas relações poderia ser contornada pelo próprio aspecto das relações lógicas entre os fatos, no entanto, particularmente no caso da empresa $\mathrm{D}$, em muitos casos, houve somação, numa mesma árvore, de desrespeito a diversas regras e/ou recomendações, de modo que a ausência da seta realmente limita o entendimento da árvore por parte de seu leitor. O problema mais freqüente foi a impossibilidade de identificar o sentido de relação entre os fatos, seja em "árvores" em que a equipe incluía setas com sentidos diversos, seja naquelas em

\footnotetext{
5 Informação verbal de Michel Monteau à Prof ${ }^{a} \operatorname{Dr}^{\mathrm{a}}$ Maria Cecília Pereira Binder, durante participação na "European Conference on Safety in the Modern Society" Helsinki, Finlândia, 15-17 september 1999.
} 
que o desenho incluía configurações inusitadas, ou seja, totalmente diferentes das apresentadas pelos autores do método.

Em 35 (46,6\%) árvores, foram identificados erros de lógica no desenho. Trata-se de erros identificados pela simples visualização dos esquemas, que incluem, nesses casos, representações que não devem existir, como, por exemplo, fatos habituais originando variações ou variações originando fatos habituais. Considerando-se que, em 25 (33,3\%) árvores, não houve classificação dos fatores segundo habitualidade, fato que impossibilitou a verificação de erros de lógica no desenho, a proporção desse tipo de erros nos desenhos eleva-se a $70 \%$. A proporção de árvores em que houve identificação desses erros também foi influenciada pelo fato de que, em 34 casos, houve registro de apenas 1 fato habitual, diminuindo as chances de aparecimento dos erros de desenho.

Publicações mais recentes, destinadas à formação de pessoal no uso do método, enfatizam a existência de "relações perigosas" ou desenhos que não devem existir nas árvores, buscando facilitar aos treinandos o domínio de suas regras. A mera observação do desenho permite à equipe identificar a presença desse tipo de erro, e sua existência em proporção tão elevada revela falha de formação também nesse aspecto (Ledeme 1995; Binder 1997).

A importância do respeito às relações lógicas entre fatos representados nas árvores também foi ressaltada com a introdução do sinal de interrogação a ser usado nos desenhos, por exemplo, nos casos em que as variações ocorridas não chegavam a ser percebidas sequer pelos acidentados e em situações em que se desejava assinalar a inexistência de informações que permitissem esclarecer o ocorrido. Em nenhuma das 75 árvores analisadas, houve inclusão desse sinal, apesar de indicação técnica em diversos casos.

Como resultado do conjunto de problemas citados em 41 (54,6\%) árvores, o desenho foi considerado desorganizado. As figuras 5 e 6 mostram exemplos de esquemas desse tipo. 
Figura 5. Exemplo de desrespeito às regras do método em "árvore de causas" elaborada em empresa do município de Botucatu, SP., 1997 ("árvore desorganizada").

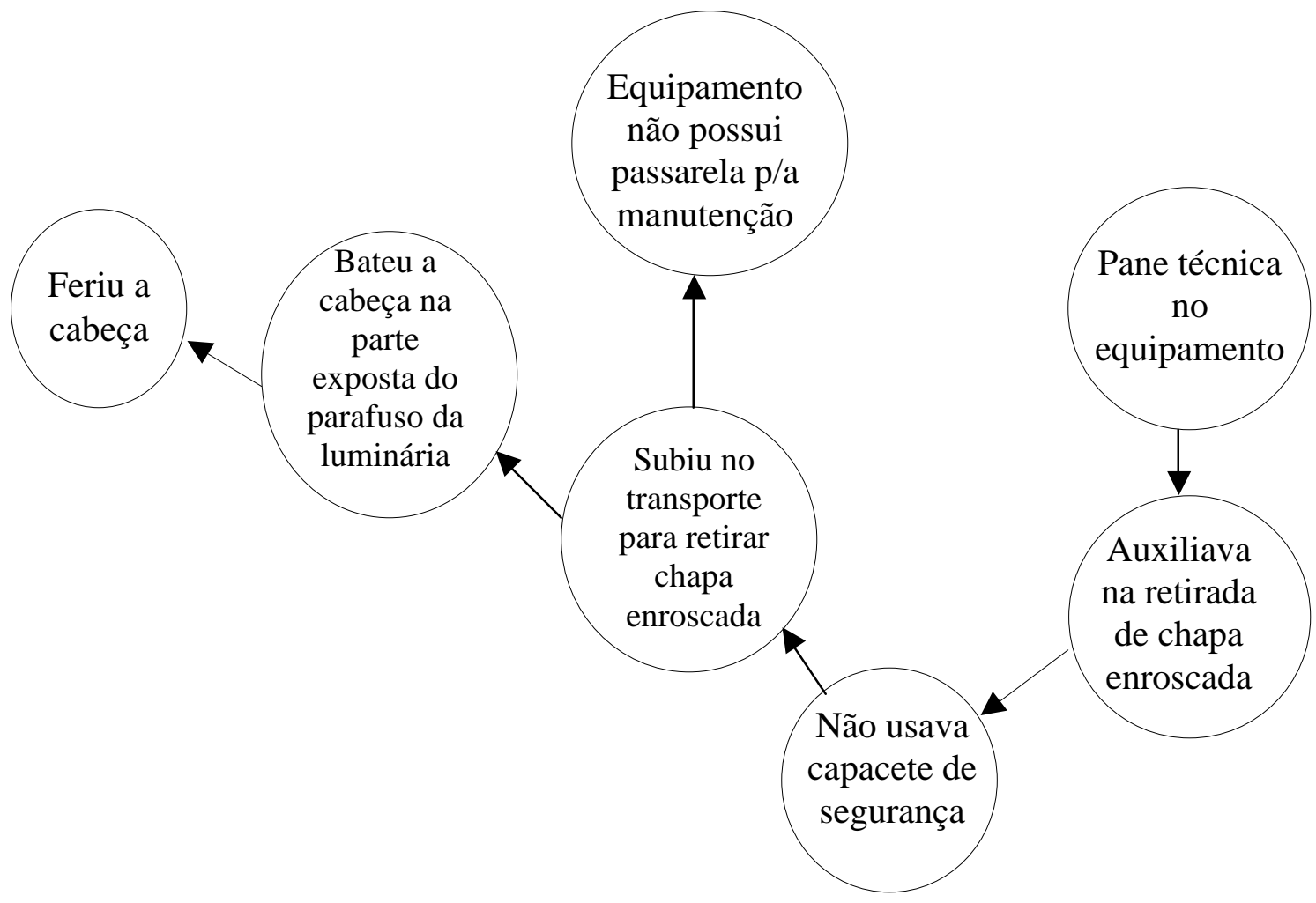

Figura 6. Exemplo de desrespeito às regras do método de "árvore de causas"' em esquema elaborado em empresa de Botucatu, SP.. 1997 (acidente ao amarrar pacote com fita de aço).

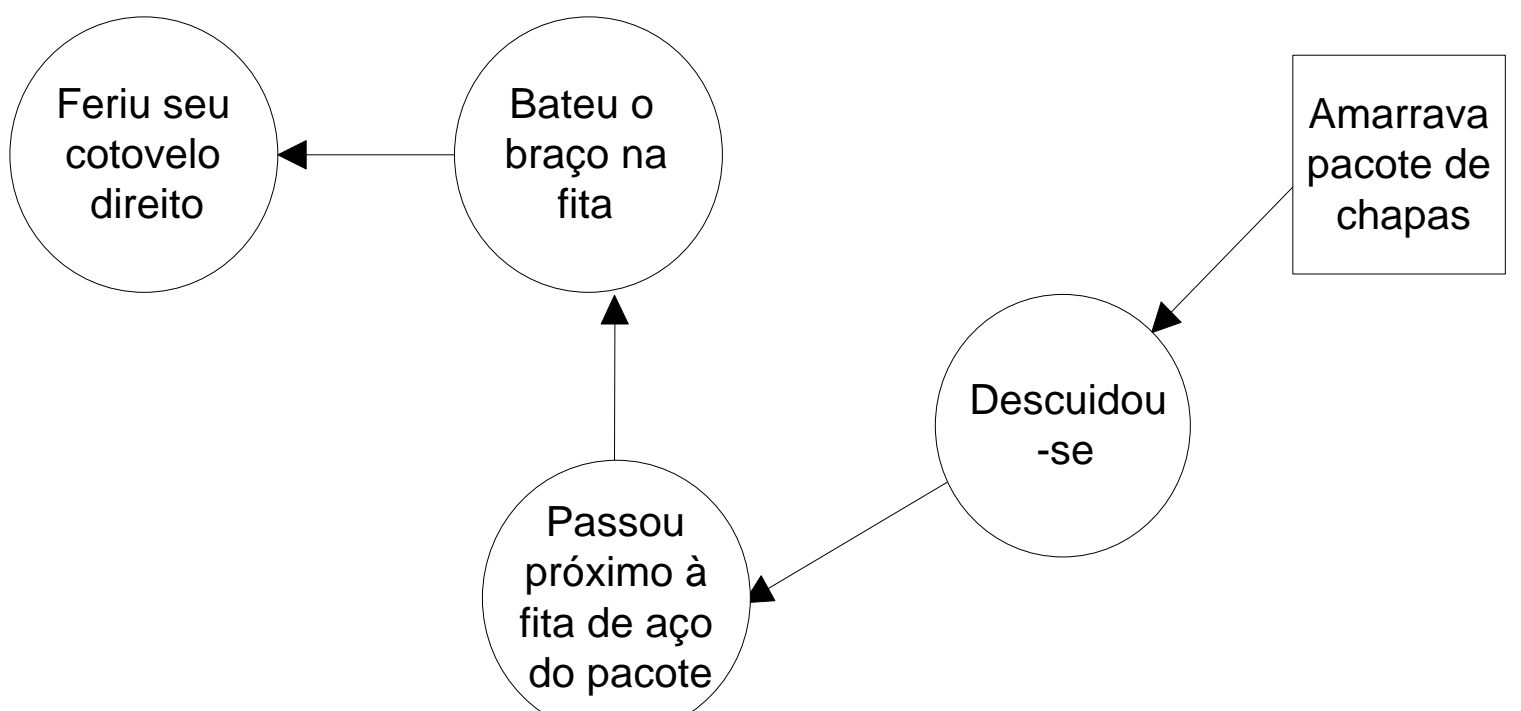


Entre as conseqüências dos problemas citados, pode-se destacar, em primeiro lugar, o comprometimento das possibilidades de uso do esquema para comunicação. Os esquemas desorganizados deixam de ser auto-explicativos e incorporam erros, como os de lógica do desenho, que podem diminuir as suas possibilidades de uso, do ponto de vista da prevenção. O prejuízo tende a ser maior nos casos em que ficam sem exploração as origens de variações que tiverem papel significativo na desestabilização do sistema, com conseqüente desencadeamento do acidente. Por sua vez, são menos importantes os erros de lógica, no desenho, que decorrem de falha na classificação dos fatores, por exemplo, com variações representadas como habituais ou vice-versa, cuja correção poderia ser feita com mudança direta no desenho.

Após essa abordagem centrada no próprio desenho, foram analisadas as relações entre os fatores representados nas árvores, com ênfase nos seguintes aspectos:

a) A relação entre antecedentes e conseqüientes pode ser considerada lógica? Essa análise foi realizada por configuração, de modo que a quantificação de erros, mesmo nos casos de conjunções, disjunções e sobredeterminações, foi sempre 1, independentemente do número de antecedentes ou conseqüentes incluídos nos esquemas.

b) Presença de fator cuja origem deixou de ser representada na árvore. De acordo com as regras do método ADC, essa busca é feita dando prioridade às variações cujas origens não foram representadas na árvore. Quando as regras do método são seguidas, inclui-se, na árvore, uma interrogação, indicando que a equipe de investigação identificou a existência daquela lacuna que, na maioria das vezes, decorre então da impossibilidade de esclarecimento do ocorrido com os recursos disponíveis no sistema. Quando a equipe de investigação descumpre essa recomendação e/ou não classifica os fatores segundo a sua habitualidade, cabe ao pesquisador tentar identificar o ocorrido, a partir da leitura do conjunto de informações obtidas da empresa acerca de cada acidente. 
A tabela 12 mostra o número de árvores, segundo presença ou não de erros de relações entre seus fatores e tipos de erros nessas relações. Verifica-se que a totalidade das árvores analisadas apresentava erros de lógica na definição das relações entre fatores e que, em 52 (69,33\%) árvores, houve registro de fatores cuja origem deixou de ser investigada. A exploração qualitativa desses fatores é feita adiante, porém, a seguir, comentam-se alguns aspectos desses erros.

Tabela 12. Árvores de causas, elaboradas por 4 empresas possuidoras de Cipa, em Botucatu, SP, 1997, segundo tipo de erros nas relações entre fatores representados nas árvores. Botucatu, SP, 2000.

\begin{tabular}{lccc}
\hline \multirow{2}{*}{ Erro } & \multicolumn{2}{c}{ Tipos de erros nas relações entre fatores } \\
\cline { 2 - 4 } Sim & Erro de lógica & Origem não investigada \\
Não & 75 & 52 \\
\hline & Total & - & 23 \\
\hline
\end{tabular}

A verificação do número de erros de lógica, por árvore, permitiu evidenciar a existência de 363 erros deste tipo na construção das relações entre os fatos incluídos nas árvores, distribuídos da seguinte maneira: 1 (1,3\%) caso com apenas 1 erro, 2 $(2,6 \%)$ com 2 erros, 50 (66,6\%) árvores com 3 a 5 erros, 19 (25,3\%) casos com 6 a 9 erros, $2(2,6 \%)$ com 11 erros e $1(1,3 \%)$ com 20 erros. A média de erros foi 5. A forma de contagem adotada fez com que o número de erros registrados fosse o menor possível na análise da árvore, pois, em diversos casos, numa mesma configuração conjunção ou disjunção -, houve constatação de mais de 1 erro. Outro aspecto que pode ter contribuído nesse sentido foi o pequeno número de fatores presentes nos esquemas, conforme mostrado na tabela 10.

As 3 árvores que apresentavam pequeno número de erros foram montadas para acidentes considerados relativamente simples, classificados como de tipo 1 de Monteau e cujos esquemas incluíam número tão pequeno de fatores, que poderiam ser classificados como "bonsais". Trata-se de esquemas que, se adequadamente elaborados, incluiriam mais relações que as representadas originalmente. Esse tipo de esquema quase que se reduz à apresentação da lesão e de sua origem e, de modo geral, é representado sem erro, na maioria dos desenhos. Por isso mesmo, não se podem tomar esses 3 casos com pequeno número de erros como indício de domínio das regras do método por profissionais das empresas em questão. 
A exploração do tipo de erro de lógica cometido é ilustrada a seguir, inicialmente, com o exemplo do fator "falta de experiência", que apareceu em 17 árvores elaboradas na empresa D como antecedente, ou seja, fator que dá ou participa da origem de diferentes fatores, registrados no Quadro 1.

\begin{tabular}{|l|c|}
\hline $\begin{array}{l}\text { Quadro 1. Conseqüentes incluídos como originados do fator "falta de experiência” } \\
\text { do acidentado, em “árvores de causas” da empresa D. Botucatu, SP, 1997. }\end{array}$ \\
\hline \multicolumn{1}{|c|}{ Conseqüentes } & Quantidade \\
\hline Foi atingido pela fita de aço & 2 \\
\hline Interpretação errônea na execução da tarefa & 2 \\
\hline Tarefa não habitual & 1 \\
\hline Não percebeu o rolete de transporte próximo de sua mão & 1 \\
\hline Abria a porta da câmara & 1 \\
\hline Colocou a mão embaixo do pallet & 1 \\
\hline Segurava (mangueira de incêndio) para limpeza do pátio & 1 \\
\hline Substituía o operador em férias & 1 \\
\hline Não desligou a chave de acionamento da serra & 1 \\
\hline $\begin{array}{l}\text { "Quando o parceiro puxou a fita” + "Quando passava a fita sob o } \\
\text { pacote” }\end{array}$ & 1 \\
\hline Apertou a fita demasiadamente & 1 \\
\hline Problema de enfermidade com nenê & 1 \\
\hline Não fez o retrocesso antes entupir & 1 \\
\hline Chapa do carrinho escorregadia & 1 \\
\hline Colocar chapa antiderrapante & 1 \\
\hline
\end{tabular}

De acordo com as regras do método, fatores que permitissem conclusão relativa à contribuição de eventual falta de experiência do acidentado, na origem de qualquer evento do acidente, poderiam e deveriam estar representados na árvore e explicitados como tal na conclusão da análise ou exploração da árvore. No entanto, o que se observou, nos registros citados, foi a mera introdução da conclusão "falta de experiência”, nas árvores, sem a apresentação de fatos que ilustrem, para os leitores da árvore, as bases que permitiram à equipe de investigação a formulação desse desfecho.

Atribuir à falta de experiência do acidentado na tarefa realizada, por ocasião do acidente, fatores como "Substituía operador em férias", "Problema de enfermidade do nenê", "Chapa do carrinho escorregadia" ou "Colocar chapa antiderrapante" representa absurdo que ilustra bem o total desconhecimento das regras do método por parte dos profissionais da empresa. O mesmo se pode dizer em 
relação a fatores como "Abria a porta da câmara" e "Segurava (a mangueira de incêndio) para limpeza do pátio de carregamento", bastando apenas saber que, assim fazendo, o acidentado realiza operação ou procedimento habitual na tarefa em questão.

Alguns dos fatores citados representam interpretações, negações ou ausências cuja utilização é contra-indicada nas árvores de causas, exceto em situações em que correspondem a opiniões emitidas pelo próprio acidentado, em contexto que não sugere pressões, nesse sentido, ou desrespeito ao uso de regras de proteção consagradas, inclusive, na empresa em que se investiga o acidente. Esse não foi o caso da frase "Não percebeu o rolete [...] próximo de sua mão", que foi usada em descrição de acidente, durante recuperação manual de incidente que exigia a intervenção do acidentado, ou seja, a colocação de suas mãos, a poucos centímetros do rolete, em postura incômoda. Acresce que a descrição do acidente não informa como os profissionais encarregados da confecção da árvore chegam à conclusão relativa à percepção do acidentado. Nessas condições, não se pode desprezar a hipótese de que tal redação signifique, meramente, a expressão de tentativa, por parte desses profissionais, de atribuição de causa, culpa e responsabilidade pelo acidente ao próprio acidentado.

A frase "Não desligou a chave [...] da serra" aparece em novo infortúnio, envolvendo incidente e recuperação manual de incidente. $\mathrm{Na}$ empresa em questão, esse tipo de ocorrência repetia-se em diferentes momentos do processo de trabalho, com e sem acidentes (vítimas), sem a adoção de qualquer tipo de providência por parte de integrantes da segurança ou da alta gestão da empresa. Nos registros relativos a esse acontecimento, não era possível identificar:

a) a distância existente entre a chave de acionamento e o ponto em que se dá a intervenção do acidentado;

b) a existência ou não de dispositivo de parada de emergência, na zona de intervenção do acidentado; 
c) a formação recebida pelo acidentado, na empresa ou em empregos anteriores, na função em que atuava por ocasião do AT;

d) condições associadas à persistência, na empresa, de métodos de recuperação manual de incidentes e de ausência de investigação de suas origens.

Em 01 acidente, devido à presença de erro de sentido das setas, na montagem do esquema, a falta de experiência apareceu como fator terminal, sem relação com nenhum conseqüente, ou seja, sem estar participando na origem de nenhum outro fator representado no esquema. Nesse caso, o fator registrado como necessário e suficiente para explicar a falta de experiência do acidentado foi "Funcionário tentou desenroscar a chapa manualmente". Para esclarecer melhor a situação, é preciso acrescentar que o transportador envolvido nesse acidente não dispõe de nenhum dispositivo mecânico ou automático para resolução desses incidentes.

Outra frase que merece destaque é "Apertou a fita demasiadamente". No ano de 1997, ocorreram, na empresa D, 14 acidentes com ruptura de fita metálica usada na embalagem de pacotes. Em cerca de metade dos casos, a ruptura ocorre durante o ajuste de tensão, ou aperto da fita, que é feito com o uso de dispositivo cujo ajuste é manual, dependendo da observação e avaliação visual da operação por parte do trabalhador.

O elevado número de acidentes, na mesma atividade, demonstra tratar-se de operação pouco fiável e pouco segura, ou seja, nas condições dadas, o risco é permanente e não operação ou procedimento que possa ser atribuído exclusivamente à falta de experiência ou de habilitação do trabalhador. $\mathrm{O}$ fato de, em dois casos, o acidentado trabalhar no setor há cerca de 2 meses é registrado em investigações e suscita hipótese de que, nestes acidentes, a participação de operador inabilitado ou inexperiente tenha contribuído para o acidente, porém não no sentido usualmente dado a essa expressão, nas empresas, como se verá a seguir.

A tarefa em questão é essencialmente mecânica, repetida inúmeras vezes ao longo da jornada, correspondendo a situação semelhante à que, segundo a 
classificação de Rassmussen, envolveria erros humanos relacionados ao nível de execução de habilidades, com respostas quase automáticas. Nesses casos, o tempo do trabalhador na atividade parece suficiente para a sua formação, embora não para o domínio de estratégias que lhe permitam conseguir elevação do ritmo de trabalho, ou seja, domínio dos mecanismos de regulação, adotados pelos mais competentes para conseguir manter o controle da atividade nas maiores velocidades que essa costuma assumir na empresa (Amalberti 1996). Ora, tais "ensinamentos" não fazem parte de estratégias de formação desenvolvidas na empresa e correspondem ao desenvolvimento de "inteligência da prática" ou de habilidades e capacidades obtidas na própria convivência com a atividade.

A decisão adotada pelos investigadores da empresa atribui o acidente à "falta de experiência" do operador referida de modo genérico e desconsiderando as implicações que os aspectos de variabilidade de ritmo da produção têm para a formação exigida do desenvolvimento da atividade em tempo real. Essa abordagem desconsidera também as implicações que a precariedade dos recursos técnicos e materiais disponibilizados no sistema, para a execução da atividade, tem em relação à origem de riscos de acidentes. Mais grave, continua desconsiderando essa precariedade, mesmo quando ela "manda avisos (acidentes)" repetidos nesse sentido. A existência desses acidentes leva-nos a levantar questão acerca da especificidade assumida pelos mecanismos de regulação adotados pelo(s) operador(es), nesses tipos de sistemas. É a sua eficiência que garante a segurança destes sistemas; no entanto, as elevadas taxas de frequiência de acidentes, nestas empresas, mostram que o número de situações que escapam às possibilidades de regulação existentes no sistema é elevado. Ou seja, os mecanismos não são suficientes para fazer face à gravidade gerada por estados de degradação do sistema muito avançados.

As medidas de prevenção sugeridas nas investigações desses casos, na empresa, foram "Prestar mais atenção", "Tomar cuidado" e "Usar luva de cano longo", deixando intocadas as condições de realização da tarefa e mostrando, até pela repetição dos acidentes, a sua ineficácia no tocante à prevenção de acidentes semelhantes. A análise da atividade, inclusive da precariedade de seus componentes técnicos, continua excluída da abordagem da empresa. 
A tabela 13 distribui os grupos de fatores que, com maior freqüência, tiveram erro de lógica na exploração de suas origens. A partir dos fatores registrados nas árvores, foram classificados 14 grupos de fatores. Uma mesma árvore enseja a origem de mais de um grupo de fatores.

O grupo "Incidente" apareceu 27 vezes (23,28\%), sendo originado, em sua maioria, por incidentes técnicos, ou seja, falhas na conformação de uma operação em sistema técnico, como, por exemplo, o alinhamento automático de uma pilha de materiais, a alimentação de uma máquina por meio de sistema de transporte automático, etc. Como se verá adiante, em outros 8 casos, o incidente foi registrado como um dos fatores terminais da árvore, deixando de ter suas origens investigadas. Nesses casos, a árvore montada não permite a identificação das origens do incidente. Em estudo anterior, Almeida (1996) criticou a prática de interrupção de investigação, no momento da identificação da ocorrência de um incidente, pane, defeito, quebra ou fator semelhante, e recomendou sua continuação até o esclarecimento de suas origens.

Tabela 13. Grupos de fatores em cujas origens foram registrados erros de lógica, em 75 árvores de causas, elaboradas por 4 empresas de Botucatu, SP., no ano de 1997.

\begin{tabular}{lccc}
\hline \multicolumn{1}{c}{ Grupos de fatores } & QT & \% \\
\hline Incidente & 27 & 23,28 \\
Modo operatório inadequado ou perigoso & 24 & 20.69 \\
$\begin{array}{l}\text { Recuperação de incidente } \\
\text { Ambiente físico inadequado ou desorganizado, máquina } \\
\text { proteção }\end{array}$ & 12 & 10,34 \\
Falha de manutenção & 9 & 7,76 \\
Co-atividade, interação entre tarefas & 8 & 6,90 \\
Aumento de pressões de tempo, atrasos ou paradas, horas extras & 7 & 6,03 \\
Uso de meios impróprios, catacrese & 6 & 5,17 \\
Material deteriorado, impróprio, com defeito ou em falta & 6 & 5,17 \\
Operador inexperiente, redução de efetivo & 4 & 3,45 \\
Falhas na divisão de tarefas, designação improvisada & 3 & 2,59 \\
Desativação de medida de prevenção & 2 & 1,72 \\
Dobra de turnos & & 2 & 1,72 \\
Outros & 2 & 1,72 \\
\hline & & 4 & 3,45 \\
\hline
\end{tabular}

Por $12(10,34 \%)$ vezes, a ocorrência de incidente ensejou tentativa de recuperação em cujo curso sobreveio o acidente. Nesses casos, a recuperação 
implicou em intervenção manual do acidentado, dentro de zona de perigo habitualmente não acessada, por vezes, exigindo posições incômodas e proximidades de partes do corpo do trabalhador com segmentos ou componentes de sistema técnico recolocados em movimento imediatamente após a correção buscada. Tais formas de intervenção poderiam ser classificadas no grupo "modos operatórios inadequados e perigosos", porém, devido à particularidade de sua relação com os incidentes, considerada importante para fins de exploração e formulação de medidas de prevenção, foram classificadas como grupo à parte. Na literatura, parte desses acidentes aparece discutida como envolvendo religação inadvertida ou recuperação manual de incidentes (Rouhiainen 1982).

Juntos, os grupos de fatores "Modos operatórios inadequados e perigosos; Ambiente físico inadequado ou desorganizado, máquina sem proteção; Uso de meios impróprios, catacrese; Material deteriorado, impróprio, com defeito ou em falta" foram registrados 43 vezes $(37,07 \%)$, e os grupos "Falha de manutenção e Desativação de medidas de proteção", 10 (8,62\%). Regra geral, na análise da empresa, esses fatores foram tratados como opções dos acidentados, independentemente do contexto em que surgiam. Ao contrário, pode-se afirmar que o primeiro conjunto desses fatores relaciona-se, diretamente, a aspectos técnicos de formas de gestão da produção propriamente dita, ou seja, às escolhas de tecnologia, meios e materiais a serem empregados na produção. Em síntese, referem-se a decisões estratégicas e fundamentais no processo de produção.

Os fatores ligados à manutenção interferem, diretamente, nas condições em que vai se dar a produção, sendo de particular importância na origem de situações como quebras e panes que, com freqüência, exigem intervenção em ambientes e postos de trabalho desfavoráveis. Além disso, associam-se com pressões de tempo, insuficiência de recursos, restrições à cooperação de colegas e outras capazes de ensejar sofrimento, ansiedade, aumento da fragilidade dos recursos usados na gestão do trabalho e elevação do risco de acidentes.

Os grupos de fatores "Co-atividade, interação entre tarefas; Aumento de pressões de tempo, atrasos ou paradas, horas extras; Operador inexperiente, redução de efetivo; Falhas na divisão de tarefas, designação improvisada; Dobra de turnos", 
somados, apareceram 20 vezes $(17,24 \%)$. Trata-se de grupo que ilustra bem a importância de formas de gestão da produção que poderiam, aparentemente, ser subdivididas em dois subgrupos. Um primeiro, incluindo decisões ligadas às práticas de absorção, formação e utilização de mão-de-obra, nas condições rotineiras de produção, que, sendo inadequadas, fragilizam de modo permanente a segurança do sistema, e um segundo, relativo às decisões adotadas na vigência de perturbações que desestabilizam o sistema, ou seja, aquelas que mostram as estratégias adotadas na tentativa de correção, recuperação ou restabelecimento do controle ou condições rotineiras em que se dá a produção.

A exploração adequada das origens de fatores pertencentes ao primeiro subgrupo é relativamente mais simples, necessitando interlocução entre "segurança" e "pessoal". Uma exceção, pela complexidade que pode assumir, é a exploração dos aspectos da gestão de pessoal, em situações de co-atividade, interferência entre atividades, trabalho desenvolvido por grupo ou equipe de trabalhadores, etc. No caso do segundo subgrupo, exige-se investigação que inclua busca ativa de "causas das causas", ultrapassando os limites da origem dos mecanismos da lesão e estendendose, por vezes, até antecedentes tardios do acidente. Além da complexidade "técnica" desse procedimento, sua condução ultrapassa os limites das competências habitualmente atribuídas à função segurança, na maioria das empresas.

A empresa A, que teve 61 acidentes registrados, e a $\mathrm{C}$, que teve 2 acidentes registrados, elaboraram apenas 1 árvore cada, no período estudado, mesmo tendo entre os seus profissionais alguns submetidos a treinamentos destinados ao domínio do método. A empresa $\mathrm{C}$ formalizara a adoção do método ADC como rotina interna, inclusive com elaboração de manuais específicos. Suas árvores mostraram, respectivamente, 4 e 5 erros, num total de 8 e 5 relações representadas nos esquemas. Ou seja, no caso da empresa $\mathrm{C}$, a totalidade das relações mostradas na árvore incluía erros. É importante esclarecer que essas duas árvores se mostravam organizadas e seguiam recomendações do método comentadas até aqui.

Nessas duas empresas, os erros identificados nas árvores poderiam estar associados à não-utilização rotineira do método, mais importante na empresa $\mathrm{A}$, e a falhas na estratégia de formação adotada nas mesmas, particularmente na empresa $\mathrm{C}$, 
onde não houve acompanhamento do uso do método com discussões envolvendo instrutores experientes e com domínio da aplicação das regras lógicas, conforme discutido em experiência francesa (Pham 1989, Cuny 1995).

Em experiências de formação de pessoal no domínio do método ADC e em análises de erros cometidos por formandos, aponta-se o uso da construção de relações lógicas como uma das maiores dificuldades relativas ao domínio da técnica (Binder 1997; Binder e Almeida 1997; Cuny 1995).

Por outro lado, nas duas empresas citadas e também na empresa B, que elaborou árvores para dois acidentes, verificou-se a inclusão, nos respectivos esquemas, de fatores de natureza gerencial (operador habitual em gozo de férias, atraso na produção), habitualmente não representados em investigações superficiais e que, nos casos citados, muito provavelmente realmente contribuíram para a origem dos acidentes. Porém, sua inclusão nas árvores foi feita de modo inadequado, facilitando o surgimento de discordâncias e fragilizando as possibilidades de uso do esquema enquanto uma ferramenta útil na comunicação no interior da empresa.

Os esquemas elaborados na empresa D acumularam a quase totalidade dos erros comentados até aqui e confirmam a justeza de preocupações relativas a propostas de adoção obrigatória de uso do método ADC, em particular aquelas que apontam as possibilidades de distorções no seu uso.

\subsubsection{Quando pára a investigação conduzida na empresa?}

Em que momento foi interrompida a investigação conduzida na empresa? Para explorar essa questão foram analisados os fatores registrados como terminais nos ramos das árvores. Além de análise caso a caso de cada fator, por parte do autor, adotou-se como regra verificar a presença, como últimos fatores - ou seja, sem investigação de sua origem -, em cada um dos "ramos" ou configurações, de: a) variações registradas como tal no esquema; b) fatos classificados pelo pesquisador como variação, a partir da descrição do acidente feita pela empresa; c) fatores já descritos na literatura como associados com o aumento do risco de acidentes ou lesões ou denominados como tal na investigação feita pela empresa. 
A identificação desses fatores foi prejudicada pela desorganização de parte dos esquemas e, em particular, pelas falhas no registro das setas indicadoras do sentido de relações entre fatores. Nos esquemas sem setas, em que estas eram apenas parcialmente registradas, a identificação de fatores terminais torna-se impossível. Além disso, em diversas árvores, mostravam outros eventos iniciais além da lesão. Como não era possível refazer as árvores de todos os acidentes, optou-se por considerar apenas aqueles fatos que a observação direta da árvore permitia identificar como terminais.

Além dessas falhas, constatou-se que, em 29 árvores $(38,6 \%)$, deixaram de ser registrados fatores participantes da origem do AT que estavam presentes na descrição feita na empresa.

Em estudo recente, de modo particularmente feliz, Baumecker (2000, p. 57) lançou mão do termo da física "atratores" - "campos que atraem partículas e forças para seu interior - para denominar aqueles fatores cujo aparecimento determinava o imediato encerramento da investigação.

Em 52 (69,3\%) árvores, foi identificada a presença de fatores cuja origem não foi investigada. A distribuição desses fatores mostrou que, em 26 árvores, foi identificado 1, em 17 foram identificados 2, em 7 foram identificados 3 e, em 2, foram identificados 4 , totalizando 88 fatores, com média de 1,7 fator por AT, cujas origens deixaram de ser investigadas. A tabela 14 mostra a distribuição desses fatores por grupos.

Dos 88 fatores identificados, 28 (31,8\%) são condições físicas e/ou recursos técnicos do sistema. Os aspectos ligados à gestão de pessoal somam 22 (26.1\%), e aqueles ligados à gestão de tempos de produção, 16 (18,1\%). A ocorrência de incidentes e sua recuperação aparece $11(12,6 \%)$ vezes. Os fatores ligados a características do indivíduo, como "falta de atenção" e "mudança de estado fisiológico ou psicológico" aparecem 5 (5.6\%) vezes, e ações do trabalhador relativas a modos operatórios e uso de EPI surgem 4 (4.5\%) vezes. 
Tabela 14. Grupos de fatores registrados como terminais e cujas origens deixaram de ser investigadas, em árvores de causas elaboradas por 4 empresas de Botucatu, SP., 1997.

\begin{tabular}{|c|c|c|}
\hline Fatores & QT & $\%$ \\
\hline Condições do ambiente físico e/ou recursos técnicos do sistema & 28 & 31,8 \\
\hline Ambiente físico inadequado ou desorganizado, máquina sem proteção & 16 & \\
\hline Material deteriorado, impróprio, com defeito, falta & 8 & \\
\hline Catacrese, uso de meios impróprios & 4 & \\
\hline Aspectos da gestão de pessoal & 22 & 26,1 \\
\hline Operador inexperiente, redução de efetivo & 8 & \\
\hline Falhas na divisão de tarefas, designação improvisada & 6 & \\
\hline Falhas em treinamento & 6 & \\
\hline Co-atividade, interação entre tarefas & 2 & \\
\hline Aspectos da gestão de tempos de produção & 16 & 18.1 \\
\hline Pressões de tempo, atrasos ou paradas produção, horas extras & 16 & \\
\hline Aspectos da gestão de mudanças / perturbações da atividade & 11 & 12,6 \\
\hline Incidente & 8 & \\
\hline Recuperação de incidente & 3 & \\
\hline Características do indivíduo & 5 & 5,6 \\
\hline Falta de atenção & 2 & \\
\hline Mudança de estado fisiológico e/ou psicológico & 3 & \\
\hline Aspectos de modos operatórios & 4 & 4,5 \\
\hline Modo operatório inadequado e/ou perigoso & 2 & \\
\hline Não usar EPI & 2 & \\
\hline Outros & 2 & 2,2 \\
\hline Total & 88 & 100 \\
\hline
\end{tabular}

A identificação de condições de ambiente físicos e/ou recursos técnicos do sistema como fator de acidente mostra falha nas práticas de detecção de riscos "a priori” desenvolvidas nas empresas e confirma que o estágio de segurança das mesmas deixa a desejar. Sua elevada proporção indica que, mesmo tendo participado de acidentes anteriores, a persistência dessas condições não vem sendo adequadamente explorada, nas empresas estudadas, notadamente na empresa $\mathrm{D}$, que totalizou 71 dos 75 acidentes. A interrupção da investigação, nesse tipo de fator, ou 
sua presença como atrator é esperada, por tratar-se de aspecto que, em geral, está presente há muito tempo no sistema onde é tolerado. Às vezes, é até aceito como risco assumido e usado como parte de estratégias de "naturalização de riscos", na empresa. O trabalho "é assim mesmo". A persistência desses problemas é retomada mais adiante, neste mesmo item.

A soma dos aspectos ligados à gestão de tempos de produção e de pessoal é 38 (44\%). Trata-se de aspectos diretamente ligados à organização do trabalho. A estes acrescenta-se a existência de outros 11, ligados a incidentes e/ou sua recuperação, que também chegaram a ser representados na árvore e deixaram de ter suas origens investigadas.

A experiência do autor com cursos destinados à investigação de acidentes com o método ADC mostra que a montagem de "galhos" de árvores referentes a esses dois tipos de fatores apresenta diferenças que podem influir nas "regras de parada" adotadas no processo. No entanto, a continuidade ou aprofundamento da investigação em geral leva à identificação de inter-relações entre aspectos da gestão de incidentes e da gestão estratégica da empresa, ou seja, decisões acerca de metas de produção, recursos a serem disponibilizados e usados, etc.

A gestão de tempos de produção e a de pessoal remete a análise a aspectos cruciais da organização da produção, na empresa. Desvendar esses aspectos é desvendar o processo de escolhas ou decisões estratégicas adotadas na definição dos rumos da produção, é identificar os eventos que ensejam a adoção de mecanismos de regulação, individuais e coletivos, cuja elucidação exige análise complementar mais refinada que aquela realizada por ocasião da análise de acidentes. Trata-se de realidade "entremeada de relações de poder e de interesses econômicos" ${ }^{\text {,6 }}$ cuja exploração exige interlocutores socialmente reconhecidos como credenciados para tal.

Infelizmente, nas empresas estudadas, com exceção da empresa $\mathrm{C}$, não há sequer indícios formais de reconhecimento desse "status" e, por isso mesmo, não é

\footnotetext{
${ }^{6}$ Lima FPA 2000 (correspondência ao autor).
} 
de estranhar que, uma vez apontados, sejam abandonados como fatores terminais da investigação conduzida na empresa.

Por sua vez, nos tipos de sistemas que deram origens à quase totalidade dos acidentes estudados nesta tese, a investigação de origens de incidentes, como a quebra, defeito ou falha de um sistema técnico, assim como a de tentativa de recuperação de incidentes é processo que se inicia de modo mais simples que o anterior. Afinal, de modo geral, trata-se de processo em que predominam interações de tipo linear, que podem ser esclarecidas com o acesso ao operador ou seus colegas e a registros e/ou integrantes de equipe de manutenção. Além disso, de modo geral, é possível localizar, com os recursos do sistema ou externos a ele, hipóteses explicativas para esses eventos e identificar evidências materiais que permitem saber o que ocorreu no sistema. Num sistema dotado de mais recursos e aberto à condução da investigação, é possível conduzi-la até o "ponto limite de conhecimento, de saberes e de domínio prático dos homens das situações de produção"7.

Quando não é possível identificar de modo preciso as origens do incidente ou componentes nele envolvidos, pode ser possível especificar o ponto de parada e adotá-lo como ponto de partida para continuidade do processo, nos sistemas em que o seu esclarecimento seja considerado útil ou necessário. A investigação "a posteriori” também permite esclarecer, inclusive, interações complexas.

Entre as ações humanas que podem ganhar mais importância, nesse tipo de acidentes, estão as do subsistema de gestão de manutenção adotado na empresa, cuja exploração se encaminha para dificuldades semelhantes às anteriormente citadas em relação ao processo de tomada de decisões estratégicas, na empresa.

Também os aspectos ligados à operação habitual do sistema, como a sua capacidade e as condições em que vem sendo usado, podem estar associados à origem de incidentes, e, nesses casos, a investigação rapidamente defronta-se com ponto crítico representado pela dificuldade de identificação das decisões associadas ao uso, naquelas condições.

\footnotetext{
${ }^{7}$ Idem.
} 
A adoção de métodos como o ADC permite identificar não só os subsistemas a serem alvo de investigação complementar, como aspectos dos processos aí existentes que precisam dessa investigação. Sua utilização pode, portanto, não só contribuir para a formulação da demanda inicial no interior da empresa, como até identificar falhas grosseiras existentes nesses subsistemas, como, por exemplo: a) a existência de máquina que apresenta panes freqüentes, cuja resolução demanda intervenção eventual, em zona de perigo, e que não está incluída em programa de manutenção preventiva e/ou preditiva; b) a existência de família de incidentes que demandam recuperação manual, realizada em zona de perigo, que, em condições habituais, não recebe nenhum trabalhador; c) a inexistência de controle estatístico de incidentes e de suas causas, associada à tolerância da ocorrência de incidentes assemelhados que se repetem sem "gatilhos" que disparem cobrança da adoção de providências.

Nas empresas em questão a investigação foi interrompida tanto em fatores de risco relacionados a aspectos do ambiente de trabalho físico e ou técnico, como em fatores relacionados à organização do trabalho em sentido amplo, incluindo aspectos da gestão de pessoal, dos tempos de produção e dos incidentes aí ocorridos. Isso mostra que especialmente na empresa $\mathrm{D}$, a interrupção da investigação pode ter dever-se em parte a fatores ligados à complexidade do evento ou de seus fatores causais mas também se deve a falhas grosseiras no desenvolvimento das práticas de segurança neta empresa. Afinal, a investigação realizada mostra-se incapaz de buscar explicações mesmo para fatores causais facilmente reconhecidos como associados com aumento do risco de acidentes.

Abeytunga (citado por Hale e Glendon 1987d) aponta razões da persistência de problemas ou riscos à saúde. Seu estudo lista 15 razões, usadas por profissionais da área de segurança e saúde que atuam em empresas de construção, para justificar sua própria falta de ação diante de perigos identificados em inspeções de locais de trabalho. Mais recentemente, Oliveira JC (2000) apresenta 18 "razões que contribuem para a criação e manutenção de um problema-risco". O quadro 2 mostra as razões apontadas pelos autores citados. 


\begin{tabular}{|c|c|}
\hline \multicolumn{2}{|c|}{$\begin{array}{c}\text { Quadro 2. Razões apontadas para a persistência de problemas ou riscos à saúde, em empresas, } \\
\text { segundo Abeytunga e Oliveira }\end{array}$} \\
\hline Abeytunga & Oliveira \\
\hline $\begin{array}{l}\text { 1. Limitação de recursos para remoção do } \\
\text { perigo }\end{array}$ & $\begin{array}{l}\text { 1. Falta de percepção ou desconhecimento da } \\
\text { existência de risco na condição existente }\end{array}$ \\
\hline $\begin{array}{l}\text { 2. Ultrapassagem dos limites das tarefas ou } \\
\text { atribuições dos profissionais }\end{array}$ & $\begin{array}{l}\text { 2. Apesar de conhecida como risco, a sua correção não } \\
\text { era atribuição das pessoas }\end{array}$ \\
\hline 3. Aceitação dos perigos como inevitáveis & 3. Superior hierárquico decidiu assumir o risco \\
\hline 4. Influências do clima social & $\begin{array}{l}\text { 4. Falta de vontade de trabalhadores e chefias para a } \\
\text { correção dos riscos }\end{array}$ \\
\hline 5. Tradição na indústria & $\begin{array}{l}\text { 5. Longo tempo de convívio com o risco incorporou-o } \\
\text { "a normalidade" das tarefas }\end{array}$ \\
\hline $\begin{array}{l}\text { 6. Falta de competência técnica para remoção } \\
\text { do perigo }\end{array}$ & 6. Falta de providências exigindo correção \\
\hline $\begin{array}{l}\text { 7. Incompatibilidade de demandas (produção, } \\
\text { custos, qualidade versus segurança) }\end{array}$ & 7. Representação dos trabalhadores não exige correção \\
\hline 8. Dependência do trabalhador & 8. O risco nunca foi alvo de interpelação judicial \\
\hline 9. Falta de autoridade para fazer alguma coisa & $\begin{array}{l}\text { 9. Criadores não se sentem responsáveis pela } \\
\text { existência do risco }\end{array}$ \\
\hline 10. Situações contingentes & 10. O risco nunca foi motivo de acidente \\
\hline $\begin{array}{l}\text { 11. Gestão ou gerenciamento de fatores do } \\
\text { sistema de segurança }\end{array}$ & $\begin{array}{l}\text { 11. A produção é sempre priorizada em detrimento da } \\
\text { segurança }\end{array}$ \\
\hline 12. Sobrecarga de tarefas & 12. Os custos do risco são transferidos aos clientes \\
\hline 13. Práticas, políticas e regras das empresas & 13. Falta de avaliação de custos de sua existência \\
\hline $\begin{array}{l}\text { 14. Falta de informação (quebra de } \\
\text { comunicação) }\end{array}$ & $\begin{array}{l}\text { 14. Sistema de seguro de AT do país adota custos fixos } \\
\text { por ramo de atividade (não premia melhorias) }\end{array}$ \\
\hline 15. Inexistência de obrigação legal & 15. Falta de tempo para correção dos riscos \\
\hline 16. & 16. Falta de recursos para correção dos riscos \\
\hline 17. & $\begin{array}{l}\text { 17. Descrença em correções por falta de respostas a } \\
\text { solicitações anteriores }\end{array}$ \\
\hline 18. & $\begin{array}{l}\text { 18. Existência do risco não impede, nem atrapalha a } \\
\text { produção }\end{array}$ \\
\hline
\end{tabular}

Na empresa D, onde foram investigados 71 dos 75 acidentes, pode-se observar a repetição de alguns tipos de acidentes, como: 11 casos no manejo de fitas metálicas na embalagem de pacotes, 6 acidentes no manejo de marreta na embalagem de pacotes, 9 acidentes na movimentação de vagoneta em câmara da linha II, 8 acidentes no desenrosco manual de chapas em transportador automático em serra palme, 3 acidentes no desenrosco manual de toras em "boca" de triturador.

O Quadro 3 mostra causas apuradas e recomendações apontadas na investigação de acidentes no manejo de fitas metálicas durante embalagem de 
pacotes de chapas de madeira prensadas. A referência isolada, em 01 caso, a características da fita, surge como exceção às demais causas, todas referidas a falhas cometidas pelo acidentado. As medidas de prevenção incluem apenas sugestões de mudança de comportamento do acidentado. Este deveria tomar mais cuidado, não se apressar e mudar o tipo de equipamento de proteção individual. A ineficácia das medidas propostas, revelada pela persistência de acidentes em que se repete a participação de mesmos meios técnicos e modo operatório usados na atividade, ou seja, envolvendo ruptura da fita durante a tentativa de ajuste realizada no final da embalagem, é desconsiderada. A causa apurada e a recomendação permanecem as mesmas.

\begin{tabular}{|c|c|c|}
\hline $\begin{array}{c}\text { Quadro 3. Causa apurada e medidas de prevenção, recomendadas por membros de } \\
\text { Sesmt de empresa de Botucatu, SP., em investigações de 11 acidentes na } \\
\text { amarração de pacote de chapas. Botucatu, SP., 1997. }\end{array}$ \\
\hline Descrição resumida do acidente & $\begin{array}{c}\text { Causas apuradas na } \\
\text { empresa }\end{array}$ & $\begin{array}{c}\text { Medidas de } \\
\text { prevenção }\end{array}$ \\
\hline $\begin{array}{c}\text { Ao enrolar ou desenrolar fita de aço } \\
\text { usada na embalagem de pacotes, foi } \\
\text { atingido pela lateral da mesma. }\end{array}$ & $\begin{array}{c}\text { Deixar o braço muito } \\
\text { perto da fita }\end{array}$ & $\begin{array}{c}\text { Testar luva de cano } \\
\text { maior }\end{array}$ \\
\cline { 2 - 3 } & Falta de atenção & $\begin{array}{c}\text { Usar luvas e proceder } \\
\text { de forma correta }\end{array}$ \\
\cline { 2 - 3 } & Falta de treinamento & $\begin{array}{c}\text { Treinamento na } \\
\text { operação }\end{array}$ \\
\cline { 2 - 3 } & Puxar fita com muita \\
força & $\begin{array}{c}\text { Ter mais cuidado } \\
\text { Trabalhar sem pressa }\end{array}$ \\
\cline { 2 - 3 } & $\begin{array}{c}\text { Descuido } \\
\text { Pressa }\end{array}$ & $\begin{array}{c}\text { Ter mais cuidado e } \\
\text { prestar atenção }\end{array}$ \\
\cline { 2 - 3 } & $\begin{array}{c}\text { Características da fita } \\
\text { (rígida, bordos cortantes) }\end{array}$ & $\begin{array}{c}\text { Testar luva de cano } \\
\text { maior }\end{array}$ \\
\hline
\end{tabular}

Os fatos citados e os apontados no quadro permitem sugerir que algumas das razões apontadas por Abeytunga e por Oliveira também possam estar influenciando o que se passa na empresa em questão. No entanto, a situação mostrada no quadro sugere que, nessa empresa, associem-se, seja a ocultação de problemas, continuamente omitidos em investigações conduzidas e/ou discutidas por profissionais especializados, seja a desconsideração de fatores eventualmente identificados, por ocasião da formulação de medidas de prevenção. Esses dois aspectos permitem suspeitar que, nessa empresa, possa também ocorrer ação deliberada, não baseada em desconhecimento ou outros dos aspectos apontados por Abeytunga, e mais próxima da noção de risco assumido, apontada por Oliveira JC (2000). 
É preciso considerar que, em casos de acidentes como os relatados no quadro 3 , o fato de a lesão resultante ser considerada sem gravidade pode associar-se à tolerância observada na empresa. Além disso, a adoção da concepção fatalista, por parte da equipe de segurança, também pode contribuir para a mesma situação.

Nenhum dos acidentes em questão foi alvo de análise, por parte do autor, e tampouco a atividade de amarração do pacote de chapas foi alvo de análise ergonômica; no entanto, as informações disponíveis permitem afirmar tratar-se de situação sujeita a fracassos e acidentes, envolvendo características dos recursos técnicos disponíveis: a fita metálica e o dispositivo usado para puxá-la e cortá-la controlado por inspeção visual e pela habilidade do trabalhador. Insistir na busca de "remendos" como correções para esses acidentes parece caminho fadado ao insucesso. Nessas situações, a solução ideal parece ser a completa revisão e a concepção de proposta alternativa. Afinal, a simples mudança da fita por outra de material não cortante, embora possa diminuir as chances de novos cortes ou lesões, não elimina a possibilidade de rupturas da fita nem suas conseqüências para a atividade.

O enfrentamento desse tipo de situação também pode beneficiar-se de sistemas de auditorias ou de controles estatísticos que definam situações consideradas inaceitáveis e que, uma vez atingidas, desencadeiem intervenção e nova avaliação. A situação mostrada tem todos os elementos necessários à sua identificação, as ocorrências foram detectadas e registradas e, no entanto, o sistema de gestão de segurança da empresa contentou-se com abordagem burocrática que repete a recomendação de medidas que já se demonstraram ineficazes para a correção do problema.

\subsubsection{A exploração das árvores: como os esquemas foram usados na prevenção?}

A Tabela 15 mostra fatores registrados nas árvores que deixaram de ser explorados, por ocasião da formulação de sugestões de medidas de prevenção. 
Tabela 15. Grupos de fatores registrados em árvores e que deixaram de ser explorados na formulação de sugestões de medidas de prevenção por $\mathbf{4}$ empresas de Botucatu, SP., 1997.

\begin{tabular}{lcc}
\hline \multicolumn{1}{c}{ Grupos de fatores } & QT & $\mathbf{\%}$ \\
\hline Incidente & 25 & 19,2 \\
Modo operatório inadequado e/ou perigoso & 21 & 16,2 \\
Pressões de tempo, atrasos ou paradas de produção, horas extras & 20 & 15,4 \\
$\begin{array}{l}\text { Ambiente físico inadequado ou desorganizado, máquina } \\
\text { proteção }\end{array}$ & 12 & 9,2 \\
Recuperação de incidente & 9 & 6,9 \\
Operador inexperiente, redução de efetivo & 9 & 6,9 \\
Co-atividade, interação entre tarefas & 7 & 5,4 \\
Catacrese, uso de meios impróprios & 7 & 5,4 \\
Material deteriorado, impróprio, com defeito, falta & 6 & 4,6 \\
Falhas na divisão de tarefas, designação improvisada & 6 & 4,6 \\
Mudança fisiológica, psicológica & 3 & 2,3 \\
Falhas de manutenção & 2 & 1,5 \\
Falhas em treinamento, formação & 1 & 0,8 \\
Outros & 2 & 1,5 \\
\hline
\end{tabular}

Observa-se que, apesar de os grupos de fatores "Incidentes" (25 registros) e "Recuperação de Incidentes" (9 vezes) aparecerem na investigação de acidentes, não são considerados na formulação de medidas de prevenção. A mesma omissão repetiu-se em relação aos grupos "Modo operatório inadequado ou perigoso" (21 vezes), "Ambiente físico inadequado ou desorganizado, máquina sem proteção" (12 vezes), "Catacrese, uso de meios impróprios" (7 vezes), "Material deteriorado, impróprio, com defeito, falta" (6 vezes), totalizando 46 fatores cuja presença só é esperada em sistemas em que a segurança apresenta falhas evidentes e facilmente identificadas por simples inspeções.

Evidencia-se também que os grupos de fatores "Pressões de tempo, atrasos ou paradas de produção, horas extras, dobra de turnos" (registrado 20 vezes) e "Coatividade, interação entre tarefas" ( 8 vezes), mesmo quando apontados como 
participantes do processo causal de acidente, não são tratados como tal, por ocasião da formulação de recomendações preventivas.

Os grupos de fatores "Operador inexperiente, redução de efetivo e Falhas em treinamento, formação" (10 vezes) e "Falhas na divisão de tarefas, designação improvisada" (06 casos) totalizam 16 eventos, em que nem mesmo recomendações genéricas relativas a treinamento de trabalhadores foram formuladas.

Merece destaque o fato de que a formação no uso do método de árvore de causas incentiva os formandos a adotarem sistematização de procedimentos que contribua para evitar, justamente, omissões desse tipo. Assim, recomenda-se a elaboração de lista de medidas de prevenção, partindo de cada um dos fatores registrados no esquema do acidente. Esse procedimento não era adotado na empresa, podendo ter contribuído para a freqüência de omissões observada.

Partindo desse conhecimento, pode-se supor que falhas na formação dos profissionais das empresas estudadas, notadamente da empresa $\mathrm{D}$, que investigou a quase totalidade dos acidentes citados, tenham contribuído para esse achado.

As listas de razões apresentadas por profissionais de empresas a Abeytunga (apud Hale e Glendon 1987d) ou elaboradas por Oliveira JC (2000), como explicações para omissões face a perigos evidenciados, acrescentam leque de fatores que poderiam ter contribuído para a omissão, na empresa $\mathrm{D}$, onde ocorreram 71 dos 75 acidentes aqui analisados.

No caso de fatores de natureza gerencial, ligados à organização do trabalho, assim como daqueles associados a incidentes técnicos e à sua recuperação, ou seja, eventos que se associam diretamente a componentes técnicos do sistema controlados por setores alheios à segurança, a ausência de sugestões poderia associar-se tanto a aspectos como a relativa complexidade de medidas corretivas necessárias (fragilidade técnica dos envolvidos no processo), como a aspectos da fragilidade institucional ou política do setor segurança face aos demais. Esta fragilidade inibe a formulação de sugestões cuja adoção exige decisão que extrapole o campo habitualmente reconhecido como próprio da segurança. 
No entanto, é importante não esquecer que quase $60 \%$ das recomendações de prevenção sugeridas nos acidentes da empresa D corresponderam a sugestões de mais atenção, outras mudanças de comportamento ou treinamentos do acidentado. Essas medidas são semelhantes às apontadas em investigações que resultam em atribuição de culpa ao acidentado, o que, de acordo com Wigglesworth (1978), inibe a formulação de sugestões de prevenção.

Por fim, o fato de permanecerem sem abordagem problemas evidentes e que chegaram a ser identificados na descrição do acidente, com ou sem inclusão no respectivo esquema, sugere ainda que, em muitos casos, a existência desse tipo de investigação, nas empresas em questão, assume aspecto de mera formalidade burocrática, sem preocupação de natureza técnica ou profissional acerca de sua qualidade e/ou de seus resultados, fato, aliás, corroborado pela repetição de diversos tipos de acidentes semelhantes, ao longo do ano, na empresa $\mathrm{D}$, sem que nenhuma providência efetiva no sentido de sua correção tivesse sido adotada.

A Tabela 16 mostra fatores que, apesar de incluídos na descrição do acidente elaborada na empresa, não o foram na árvore do respectivo acidente e também deixaram de ser explorados por ocasião da formulação de sugestões de medidas de prevenção para o mesmo acidente. Observam-se 23 referências a fatores, dos quais com exceção de um, risco assumido, todos os demais incluem-se em grupos já citados anteriormente.

O grupo de fatores que com maior freqüência (6 vezes) foi identificado na descrição do acidente feita na empresa e que, apesar disso, foi desconsiderado na elaboração de sugestões de medidas de prevenção, foi "Ambiente físico inadequado ou desorganizado, máquina sem proteção". Em segundo lugar, com 3 referências, apareceu "Modo operatório inadequado ou perigoso" e, em seguida, com 2 fatores cada, apareceram os grupos "Material deteriorado, impróprio, com defeito ou em falta", "Catacrese, uso de meios impróprios" e "Falhas na divisão de tarefas, designação improvisada". Também em relação a esses grupos de fatores, repete-se a situação comentada em relação ao apresentado na tabela 15. Fatores facilmente identificados como potencialmente acidentogênicos, presentes de modo permanente 
nos locais de trabalho, e fatores da organização do trabalho foram desconsiderados na elaboração de recomendações de prevenção.

Tabela 16. Grupos de fatores descritos em análises de acidentes, que deixaram de ser incluídos nas respectivas árvores e de ser explorados, na formulação de sugestões de medidas de prevenção, por 4 empresas de Botucatu, SP., 1997.

\begin{tabular}{|c|c|c|}
\hline Grupos de fatores & QT & $\%$ \\
\hline Ambiente físico inadequado ou desorganizado, máquina sem proteção & 6 & 26,1 \\
\hline Modo operatório inadequado ou perigoso & 3 & 13,0 \\
\hline Falhas na divisão de tarefas, designação improvisada & 2 & 8,7 \\
\hline Material deteriorado, impróprio, com defeito ou em falta & 2 & 8,7 \\
\hline Catacrese, uso de meios impróprios & 2 & 8,7 \\
\hline Operador inexperiente, redução de efetivo & 1 & 4,3 \\
\hline Recuperação de incidente & 1 & 4,3 \\
\hline Falhas de manutenção & 1 & 4,3 \\
\hline Co-atividade, interação entre tarefas & 1 & 4,3 \\
\hline Posto de trabalho inadequado & 1 & 4,3 \\
\hline Risco assumido & 1 & 4,3 \\
\hline Outros & 2 & 8,7 \\
\hline
\end{tabular}

Este último aspecto mostra que essas falhas da investigação não podem ser atribuídas, exclusivamente, a aspectos da complexidade da situação em que veio a ocorrer o acidente, pois o mesmo tipo de omissão repete-se em relação a fatores de acidente cuja resolução é de ampla difusão na literatura de segurança.

Vale acrescentar que esse estudo se restringe às investigações conduzidas nas empresas, sem realização de nova análise, fato que impede a identificação de falhas decorrentes da realização da coleta e registro de fatos.

Os achados mostrados nas duas últimas tabelas indicam que, nem mesmo com a tentativa de adoção do método ADC, as investigações conduzidas nas empresas estudadas resultaram em recomendações de prevenção que explorem todos os fatores de acidentes identificados e registrados nas árvores. 
Esses achados revelam que, às falhas no domínio da técnica, anteriormente citadas, somam-se, nesse caso, outras, relativas à etapa de exploração dos esquemas, por parte dos técnicos das empresas.

Na casuística estudada, apenas uma empresa, que fez esquema para um único acidente, definiu critérios de análise das árvores. A utilização de roteiros de exploração dos fatores das árvores sugeridos na literatura e/ou em cursos relativos ao método ADC poderia contribuir para a diminuição das falhas aqui apontadas e reforça a importância da adoção de cuidados (ou "muletas") a serem usados, principalmente durante as fases iniciais de implantação do método, por profissionais que não possuem adequado domínio de suas regras.

Os achados descritos corroboram opiniões anteriormente firmadas na literatura, apontando, como Almeida (1995), que "Os interessados no uso deste método não devem subestimar as dificuldades relativas ao domínio dos seus princípios fundamentais" (Méric 1984; Pham 1989; Binder e col. 1995; Binder 1997; Binder e Almeida 1999).

As investigações analisadas mostram quantidade de falhas tão elevada que, por si, justificam alerta a ser feito a todos os interessados em aprimorar a(s) prática(s) de investigação de acidentes que adotam. As escolhas a serem feitas devem basear-se em cuidadosa análise de sua realidade de segurança e identificação precisa dos objetivos que se buscam com a mudança pretendida. Os modismos e a adoção acrítica de técnicas pouco difundidas devem ser evitados. O início da implantação de novas técnicas deve ser precedido por adequada formação dos profissionais disponíveis na empresa, e as condições necessárias ao sucesso dessa implantação devem ser previamente acordadas entre os diversos setores a serem envolvidos na sua utilização, inclusive aqueles de níveis hierárquicos mais elevados na empresa.

Os métodos de investigação destinados à abordagem de acidentes em sistemas de baixa acidentalidade devem ser considerados elemento adicional de uma política de segurança e, por isso mesmo, não se justificam tentativas de implantação em sistemas que ainda não resolveram problemas considerados óbvios e de fácil detecção com ferramentas mais simples, como, por exemplo, as inspeções de 
segurança (Almeida 1995; Méric 1984; Favrot e Milbergue 1985; Pham 1989; Binder e col. 1995; Binder 1997; Binder e Almeida 1999).

\subsubsection{Falhas na investigação de acidentes e nas práticas de} segurança

$\mathrm{Na}$ totalidade das investigações conduzidas na empresa $\mathrm{D}$, a descrição dos fatores habituais, como, por exemplo, características técnicas do sistema participantes do AT, foi insuficiente. No caso dos acidentes de tipo 01, essa omissão, com freqüência, associa-se a sugestões de medidas de prevenção que, sistematicamente, desconsideram a necessidade de correções de problemas de segurança presentes de modo permanente na atividade em questão e que, por isso mesmo, poderiam ser identificadas por simples inspeção de segurança. Em outros casos, essa omissão impede ou dificulta ao leitor da investigação a identificação de exigências da tarefa, que diminuem a sua confiabilidade e/ou segurança e que, até então, não haviam sido identificadas como tal. Um exemplo dessa última situação é o fato de o ajuste da tensão de fita metálica usada no empacotamento basear-se na observação e avaliação visual feita pelo operador. A simples descrição dessa característica pode auxiliar sua identificação e conseqüente abordagem, por ocasião da formulação de medidas de prevenção.

A palavra "pode" é usada pelo autor para destacar que essa ação, aparentemente trivial, não é abordada como tal nas práticas de investigação, nas empresas em questão. Hale e Glendon (1987d, p. 165 e seguintes) citam estudo de Abeytunga, acerca da identificação de riscos por supervisores, em que $8 \%$ dos perigos ("hazards") não foram considerados reais e, em outros $10 \%$, não houve identificação de responsável por sua remoção. Na opinião dos autores, esse achado significa que, segundo os supervisores, existe "nível de aceitação de alguns perigos ("hazards") tão fixado ("embebed") como parte da tarefa, da indústria ou da maneira que se trabalha que não podem ser removidos" (p. 167). Esse fato reflete grau de aceitação de inação por parte dos supervisores face a esses riscos. Por sua vez, a presença desses dois grupos de riscos sugere a existência de dois níveis de aceitação: no primeiro, a situação é considerada de tal forma parte do sistema que não chega a 
ser rotulada como risco; na segunda, ela é identificada como risco, e a necessidade de ação, apesar de presumivelmente considerada, é rejeitada (p. 168).

Uma das explicações aventadas pelos autores para essa compreensão é a natureza complexa e rapidamente cambiante do trabalho e de suas demandas, porém essa não parece ser exatamente a situação verificada nas empresas estudadas. Afinal, nesse estudo, chama a atenção a repetição de alguns tipos de infortúnios: 14 acidentes na embalagem de pacotes com fita metálica, 4 acidentes ao alinhar pacotes com uso de marreta, 8 casos em tentativa de recuperação de incidente em transportador automático de chapas, 8 casos na movimentação de vagonetas em câmara de resfriamento, etc.

Apesar disso, as situações abordadas neste estudo são heterogêneas, incluindo tarefas relativamente simples e facilmente identificáveis como típicas de modos operatórios inadequados e pouco seguros até acidentes em sistemas técnicos de grandes proporções, operados por painéis situados fora do corpo das máquinas e exigindo presença de auxiliar junto à zona de operação. Nos dois casos, a repetição de acidentes com tantos aspectos assemelhados, que não se resolvem com as medidas de prevenção sugeridas, deve suscitar, no mínimo, a abertura de discussão relativa à superação do problema. A atitude das equipes de investigação de apego à repetição das mesmas medidas - sugestões de mudanças de comportamento do acidentado -, que se mostram insuficientes para a solução desses acidentes, permite considerar que, em grande parte das empresas estudadas, tais procedimentos assumem característica de mera formalidade, sem qualquer compromisso com a adoção de práticas efetivamente voltadas à prevenção de acidentes.

Hale e Glendon (1987d, p. 168) também apontam que a análise de Abeytunga mostra que os supervisores demonstram sentir mais controle sobre aspectos da organização física do ambiente de trabalho ("layout") que sobre métodos de trabalho usados, qualidade ou quantidade da força de trabalho, das instalações e equipamentos fornecidos para o trabalho. Neste estudo, as equipes de investigação parecem desconsiderar também aspectos importantes de postos de trabalho e ambientes físicos, como ilustrado no caso da empresa D. Por outro lado, apesar do grande 
número de vezes que surgem sugestões de "treinamento" como parte das medidas de prevenção sugeridas, não parece que isso signifique preocupação das equipes de segurança abordadas com o tema da "qualidade da força de trabalho" da empresa, pois, além do fato de a medida ser incluída de forma genérica, ela aparece com grande frequiência - acompanhada da recomendação "prestar mais atenção" - em acidentes em atividades com exigências tais, que as habilidades e capacidades aprendidas pelo trabalhador claramente não são suficientes para seu controle.

Hale e Glendon (1987b, p. 40 e seguintes) lembram que, para a maioria das pessoas, os perigos não representam o interesse mais importante. Por exemplo, ao fazer um buraco na parede, as pessoas estariam mais interessadas em fazê-lo no local certo do que em algum eventual perigo decorrente da tarefa. "Se os programas $e$ procedimentos que o indivíduo aprendeu para realizar suas tarefas contêm os passos apropriados para mantê-lo fora do alcance dos perigos pode-se não se ter conhecimento consciente ("no conscious awareness") da presença ou não do perigo" (p. 41). Esses autores enfatizam que esse estado de 'falta de consciência' ("lack of safety consciousness") "é ambos, normal e saudável" (p.41) e acrescentam que "estar constantemente consciente do perigo é uma definição razoável de paranóia". Por fim, destacam que, de acordo com estudos que utilizaram o modelo de comportamento face ao perigo proposto por eles, o estágio de percepção dos sinais de perigo existentes na tarefa, juntamente com a adequada seleção de procedimentos do repertório disponível, emergem como de maior importância.

Embora os formulários de investigação de acidentes adotados na empresa D não incluam o campo destinado à definição de "Responsável" pelo acidente, a larga utilização de "nomes de fatores" e de conclusões acerca da(s) causa(s) que atribuem esses acidentes a "descuidos" e "falta de atenção" do acidentado permite-nos afirmar a existência de viés ou "bias" de atribuição causal, de culpa e responsabilidade, nas investigações nela realizadas.

Ao discutir a existência de "bias" semelhante em investigações de acidentes, Hale e Glendon (1987d) afirmam que ele surge "quando há alguma ambigüidade em uma situação, permitindo mais de uma interpretação. Tais ocasiões seriam mais freqüentes em situações que mudam rapidamente e quando as pessoas tentam 
reconstruir retrospectivamente ("hindsight") um acidente do qual elas podem ter sido testemunhas ou acerca do qual elas tenham apenas ouvido relatos" (p.185). Mais adiante, os autores comentam a falsa sensação de segurança, também chamada viés ou "bias" de otimismo, que advém da atribuição de responsabilidade aos outros e acrescentam: "Quando o perigo é óbvio ou grande não é provável que essa falsa sensação de segurança afete de modo importante o comportamento [...] É somente em situações de baixo ou perigo menos óbvio que essas diferenças começam a aparecer" (p. 186).

Os achados mostrados neste estudo contradizem a ressalva feita por Hale e Glendon (1987d), indicando que, nas empresas abordadas no município de Botucatu, a atribuição de causa, culpa e responsabilidade ao acidentado ocorre, independentemente da natureza e/ou tipo de perigo presente na situação que originou o acidente. Nesse estudo, chama a atenção justamente o fato de que, mesmo quando situações assemelhadas estão presentes de modo repetido, em acidentes ocorridos num mesmo ano, em uma mesma empresa, estes não são percebidos ou tratados como indício de perigo por parte das equipes de investigação.

Dois exemplos, entre outros, corroboram essa afirmação. No caso dos acidentes que iniciam com incidente técnico que demanda recuperação manual, a existência de prática de atribuição de causa ao acidentado desconsidera todas as evidências relacionadas ao contexto em que tem origem esse evento. Por vezes, desconsidera-se também a repetição de fenômenos semelhantes, reduzindo-se a observação ao momento da falha da recuperação, que é transformada em descuido ou falta de atenção do acidentado. No caso dos acidentes com ruptura de fita metálica usada na embalagem de pacotes da empresa $\mathrm{D}$, o fato de o ajuste da tensão ou aperto basear-se em avaliação visual e experiência do trabalhador e a persistência do uso de fita metálica de bordos cortantes foram sistematicamente desconsiderados, ao longo do ano de estudo, mesmo tendo sido registrados cerca de 17 acidentes no uso da fita.

Uma das inferências que se pode fazer a partir desses achados é a de que a identificação ou a definição do que seriam perigos óbvios parece adquirir importância especial nas empresas do município estudado, diferentemente do que se observa em realidades como a dos países estudados por Hale e Glendon (1987d). 
Afinal, na empresa B (metalúrgica), foi só após a ocorrência do segundo acidente na mesma prensa que se atentou para necessidade de intervenção em zona de operação aberta, permitindo acesso de partes do corpo do trabalhador. Na empresa D, a existência de recuperação de incidente em sistemas técnicos, boa parte dos quais permanece ligada durante essa intervenção, não foi abordada ou sequer identificada como perigo evidente, mesmo após a sua participação em mais de 15 acidentes, no ano estudado.

Um dos fatores que podem contribuir para a ocorrência de falhas na detecção desses riscos ou mesmo para a aceitação de sua persistência é a insuficiência técnica na formação dos profissionais que atuam nas empresas em questão. Essa hipótese revela-se particularmente preocupante por tratar de insuficiência na capacidade de Técnicos de Segurança e/ou Engenheiros de Segurança para a identificação de riscos e/ou perigos que podem ser definidos como óbvios ou evidentes.

Independentemente das razões ligadas à sua origem, a superação desse tipo de falhas pode ser auxiliada pela introdução de medidas que facilitem a caracterização de situações consideradas como de "risco grave e iminente" (Azevedo 2000) ou "check lists", a serem usados na busca de fatores de risco, como no caso de acidentes com máquinas (Magrini e Martarello 1989). Nos dois casos citados, a iniciativa adotada é fortemente influenciada pela noção de cumprimento de normas regulamentadoras vigentes. Embora esse caminho continue válido na prática, outras abordagens podem e devem ir sendo buscadas, tomando como referência o conhecimento disponível, seja acerca de fatores e situações de risco, seja das percepções de risco prevalentes nas realidades a serem abordadas. Entidades sindicais poderiam estimular o desenvolvimento de listas complementares e a defesa de sua utilização sistemática, seja por parte de membros de CIPA, seja por parte dos demais trabalhadores expostos a esses riscos.

No Brasil, uma das estratégias que pode dar frutos nesse tipo de situação e que vem sendo estimulada pelo movimento sindical de trabalhadores e também por setores do Ministério Público é a tentativa de responsabilização penal de empregadores e/ou seus prepostos. 
Outra explicação provável para esses achados é mais grave. A persistência desses problemas associa-se pura e simplesmente ao cinismo predominante no discurso dos técnicos envolvidos nas investigações, que, por sua vez, reflete cinismo, seja de gerentes da área de saúde e segurança, seja de gerentes e níveis hierárquicos superiores da empresa, em relação ao tema da prevenção de acidentes. Essa possibilidade é apontada por Dejours (1996), ao comentar opinião de Llory (1996) acerca do "silêncio" ou ausência de opiniões dos gerentes ou chefias intermediárias (“cadres"), em investigações de acidentes. Llory defende a necessidade de quebra desse silêncio e a transformação de investigações de acidentes em espaços abertos à discussão democrática, envolvendo todos os atores presentes na empresa e interessados na prevenção desses eventos. Dejours pontua o fato de que a estratégia proposta por Llory assume o pressuposto de que esses gerentes são pessoas bemintencionadas, não envolvidas, até então, nessa discussão, devido à sua desinformação acerca dos problemas em questão. Ora, o "silêncio" dos gerentes também pode corresponder à expressão de escolha estratégica consciente, de modo que a alegada desinformação não passe de desculpa cínica face à emergência do tema. E, sendo essa a situação, a estratégia proposta por Llory pode revelar-se insuficiente para fazer frente aos desafios da prevenção.

Infelizmente, os achados deste estudo parecem dar razão a Dejours, indicando que, nas empresas estudadas no município de Botucatu, as práticas e as políticas de segurança sustentam-se muito mais na obrigatoriedade de sua existência do que em mudanças culturais ou das relações de poder no interior da empresa e/ou na sociedade em geral que privilegiem a construção de ambientes de trabalho saudáveis.

Ao discutir o perigo em tarefas de rotina, Hale e Glendon (1987c) afirmam: “Comportamentos baseados em habilidades requerem um ambiente protegido [...] esta proteção deve ser dada por alguma coisa ou por alguma pessoa diferente daquela que exibe o comportamento". Após citar a operação de prensas e guilhotinas como um exemplo desse tipo de tarefas, os autores defendem: "O operador deve trabalhar na certeza que a proteção existente é 100\% segura ...” (p. 64).

Hale e Glendon (1987c) lembram que muitos que comentam a segurança costumam atribuir os erros que acontecem em tarefas industriais à falta de vigilância 
e de cuidado do operador, de modo que sua correção deve basear-se em recomendações de mais atenção na tarefa, o que, por sua vez, implica em mudar o nível de controle da mesma, elevando-o do tipo baseado em habilidades para o baseado em regras ou conhecimentos. O custo de tal mudança é o aumento da duração da tarefa com influências na produtividade. Por outro lado, se essas recomendações tiverem origens nos mesmos gerentes e diretores que, em outro momento, exigem aumento da produção, o trabalhador é colocado em um conflito sem saída ("impossible conflict") (p.66).

Esses ensinamentos parecem particularmente úteis para a reflexão acerca das medidas de prevenção recomendadas nas empresas estudadas, particularmente na $\mathrm{D}$, em que "prestar mais atenção" foi uma das mais freqüentes. A opinião de Hale e Glendon ilustra a ineficiência dessas medidas, ressaltando a superficialidade das investigações de acidentes no município, mas também a superficialidade da abordagem das informações nelas coletadas. A mera incorporação dos conhecimentos citados permite às equipes das empresas identificar a insuficiência e ineficácia de recomendação tão genérica.

Por outro lado, também chama a atenção o fato de que, no conjunto das investigações, não se observem evidências do surgimento do conflito apontado pelos autores. Ou seja, nem as demais medidas recomendadas e nem a repetição sistemática da proposta indicam a existência do tipo de conflito apontado. Dentre as hipóteses capazes de explicar esse fato, destaca-se que o processo de investigação, nas empresas estudadas, se resume a mero formalismo burocrático, cujos resultados não são alvo de avaliação interna ou externa às empresas.

O preenchimento, pelas empresas, dos anexos, de entrega obrigatória à representação do Ministério do Trabalho e Emprego, não era alvo de qualquer tipo de controle pela representação regional daquele Ministério e, na esfera nacional, recente mudança diminuiu as exigências de informações a serem entregues. Acresce que, com exceção de estudo anterior de Binder e col. (1997), desconhecem-se outros que tenham usado como fonte de informações documentos que a empresa deve preencher e manter à disposição de órgãos de fiscalização. Além disso, em 74\% (20/27) das empresas da região dotadas de CIPA que tiveram acidente registrado no ano de 
estudo, houve desrespeito a exigências legais. Dessas 20 empresas, 9 não investigaram nenhum dos acidentes que deveriam analisar.

As reuniões de CIPA representam espaço legal para o aparecimento potencial desse conflito, uma vez que nelas devem ser discutidos os acidentes ocorridos na empresa e investigados com a participação de algum de seus membros. Em nenhum caso, as recomendações registradas ${ }^{8}$ no anexo de preenchimento trimestral dessa comissão sugerem sequer a existência de questionamento às recomendações apresentadas nas fichas de investigação.

Assim, ao concluir que o acidente deveu-se à falta de atenção do acidentado ou que pode ser corrigido com mais atenção por parte deste, a investigação conduzida na empresa parece não só atender às exigências de formalidades legais, no tocante à realização de investigação, como também contribuir para o encerramento de discussões relativas às suas causas, reduzidas a comportamentos errados do acidentado, que deixam de ser alvo de discussões posteriores, inclusive no fórum institucional que deveria fazê-las.

$\mathrm{O}$ fato de, em algumas empresas, as recomendações registradas em reuniões de CIPA revelarem atitudes reivindicatórias de defesa de mudanças voltadas para a melhoria de condições de trabalho e até de denúncias repetidas de omissões da empresa, em relação às propostas formuladas, sem que os problemas identificados nas investigações de acidentes do período tenham sido abordados, sugere que, em alguns casos, o espaço de denúncia tenha sido descoberto, porém sem força para dar vida, no interior da empresa, a questionamento efetivo do desprezo mostrado em relação às questões afeitas às funções saúde e segurança.

Esse último aspecto pode ser alvo de discussões com os cipeiros e objeto de outras ações específicas de sindicatos de trabalhadores, nesse campo. Embora o alcance desse tipo de iniciativa possa ser maior naqueles locais em que se conte com bom suporte técnico, a transformação da CIPA em espaço efetivo para a discussão acerca dos impactos do trabalho sobre a saúde, ou seja, a transformação desse tipo de

\footnotetext{
${ }^{8}$ Esses documentos foram obtidos pelo autor junto à representação de TEM, em Bauru.
} 
comissão em organismo dinamizador da capacidade de pensar, debater e agir para a mudança das situações de trabalho, é questão política, que diz respeito às relações de poder dos atores sociais envolvidos nesse processo.

Em acidentes de tipo 01 de Monteau, como os ocorridos na operação de prensa com zona de operação aberta, alimentada manualmente, podem-se destacar dois inconvenientes, presentes em propostas de reforço de treinamento. O primeiro é que, contrariamente ao indicado para tarefas rotineiras, elas aparecem passada a fase de aprendizagem, ou seja, abordam o desempenho ou resposta do indivíduo ("output do sistema"). O segundo é o fato de desconsiderarem que o outro enfoque de prevenção para tarefas rotineiras seria a intervenção sobre o "design" de tarefas e equipamentos, de modo a evitar falhas na atividade.

No caso dos acidentes de tipo 2, os mesmos inconvenientes repetem-se. Afinal, a recomendação de prestar mais atenção nas operações de intervenção manual, em um sistema técnico, além de não alterar em nada o repertório de procedimentos de que o indivíduo dispõe para a tarefa, deixa inalterados os demais componentes do sistema.

A princípio, a prevenção de acidentes durante intervenção manual em zona de operação aberta deve ser buscada pela introdução de medidas que evitem o surgimento dos incidentes em questão. Deve-se considerar também a necessidade de associação de dispositivos de correção de incidentes que evitem a introdução de partes do corpo do trabalhador na zona de operação ou de desligamento automático do sistema, inclusive nas proximidades dos pontos em que ocorrem as intervenções, de modo a evitar interferências relacionadas com a introdução de "custos" adicionais para o operador, por ocasião de seu acionamento. Esses dispositivos devem ser programados com tempo de acionamento da parada do sistema o mais curto possível, para consegui-la antes de eventual entrada do operador na zona de perigo.

Destaca-se a importância de treinamentos que auxiliem o trabalhador na percepção dos riscos na tarefa. Por exemplo, McKenna e Hale (1982, p. 50) destacam as possibilidades de treinamentos no tocante à tomada de consciência do perigo e de ações arriscadas. Em acidentes semelhantes aos aqui discutidos, deve-se esclarecer, 
por exemplo, a existência ou não de possibilidade de religação automática do sistema, seja a partir de sensores existentes na zona de intervenção (eventualmente necessários para auxílio em tarefas de manutenção), que deverão ter sua exata localização indicada, seja a partir de comandos existentes em outros painéis presentes ao longo do sistema, que precisarão dispor, seja de comunicação adequada acerca da existência de seu acionamento, seja de sistema de travamento da possibilidade de religação na vigência de parada para recuperação de incidente. $O$ treinamento também deve capacitar o trabalhador no sentido do reconhecimento, tanto de sinais de perigo eventualmente presentes no sistema, como de comportamentos apropriados na vigência desse perigo.

No caso dos acidentes de tipo 2, a descrição das características técnicas do sistema é essencial para a adequada visualização do evento, além de propiciar a identificação, seja de fatores de risco de aparecimento limitado no tempo, seja de exigências da tarefa que diminuem a confiabilidade e/ou segurança do sistema não identificadas até então como tal.

\subsubsection{Pequeno comentário acerca de medidas de prevenção propostas na empresa $D$}

Entre as medidas de prevenção sugeridas nesta empresa, algumas chamam a atenção pelo que apresentam de inusitado. Destacam-se: "Mais calma, atenção e cuidado ao usar instrumento adaptado", "Não realizar tarefa que não seja de sua alçada e devidamente autorizada. Caso for necessário, utilizar equipamento adequado", "Sempre que for executar essa tarefa (fixar prego com martelo) não deixar a mão apoiando o prego [...]”, “[...] o embalador deverá segurar na ponta da fita para não ser surpreendido pelo golpe da fita", "Não utilizar mangueira de incêndio sem treinamento".

Essas medidas aparecem, de modo geral, como única providência sugerida. Em alguns casos, há acréscimo de referência ao uso de EPI, em situações em que isso pode contribuir para diminuir a gravidade de lesões, porém não tem qualquer interferência na possibilidade de repetição de acidente de mesmo tipo. 
Pode-se apontar, entre outras, as seguintes implicações das medidas citadas. No primeiro caso, o uso de instrumentos adequados em substituição ao adaptado não é considerado. No segundo, não se investigam as razões que levaram o trabalhador a comportar-se da maneira envolvida no acidente e que podem revelar a adoção, por parte de setores da empresa, de estratégias de enfrentamento de perigos que podem ser classificadas como absolutamente inaceitáveis do ponto de vista da segurança e da legislação civil e criminal vigentes. No terceiro caso, evidencia-se bem a impropriedade ou insuficiência das mensagens escritas de forma negativa. A realização da operação, fixar prego com martelo, não é colocada em questão, por exemplo, considerando a possibilidade de fixação com parafuso e uso de parafusadeira. Por outro lado, persistindo a operação, não se aponta alternativa: como o operador a realizaria sem segurar o prego com a mão? No quarto caso, a ocorrência do golpe da fita é aceita como natural, cabendo ao trabalhador evitar que ela venha a surpreendê-lo. A equipe de investigação omitiu o argumento de que a repetição de acidente similar por tantas vezes (14, no ano do estudo) também não permitiria descrevê-lo como surpresa.

Em todos os casos, é evidente a utilização de mensagem com verbo na terceira pessoa do singular, ou seja, que transfere para o acidentado o controle da situação e a responsabilidade pela ocorrência do acidente.

\subsubsection{Distorções na implantação do método ADC}

A tentativa de identificação dos métodos de investigação usados nas empresas mostrou que, nos casos apresentados como de uso de análises com o método de árvores de causas, havia número de tal forma elevado de desrespeito às recomendações dos criadores desse método, que todas as análises recebidas foram consideradas pelo autor como tendo sido realizadas com o "método de árvore de causas distorcido ou deturpado".

A expressão "distorcido ou deturpado" foi escolhida porque todos os esquemas mostram falhas em, praticamente, todas as características analisadas. Além disso, revendo a maneira como o método de árvore de causas tem sido difundido em nosso meio, Almeida (1996), Binder (1997), Almeida e Binder (1996), Binder e 
Almeida (1998) mostram que sua utilização é possível mesmo por agentes externos às empresas. Além disso, comentam dificuldades ligadas ao seu uso em conformidade com princípios fundamentais e regras definidos pelos seus criadores, destacam o abandono desses princípios e regras, evidenciado em publicações brasileiras (Lara Duca 1987; Magrini e Ferreira s/d; Ferrão 1996) e apontam a necessidade de cuidados na sua implantação, de modo a evitar, em sua utilização, distorções que inviabilizem o aproveitamento de suas potencialidades em relação ao aprimoramento de práticas de investigação de acidentes, no país.

A exploração desse tema, na literatura, evidencia estudo de Lieber (1998), que discorda dessa opinião. Partindo de referência em que Binder e col. (1995, p. 14) apontam a existência de deturpações e dificuldades na implantação e difusão do método ADC, na França e no Brasil, Lieber (1998) faz a seguinte afirmação:

[...] atribuir às deturpações o fato de algum investigador, usando um dado método, encontrar uma causa absolutamente diferente da "esperada", como alegam os proponentes da árvore de causas (ADC), é próprio (do) “discurso da neutralidade”. Sua insistência em negar a legitimidade a qualquer outra perspectiva demonstra o seu propósito em se manter contraditório, sustentando a perspectiva dominante, ao mesmo tempo, sendo sustentado por ela. (p. 184.Grifos meus; as aspas são do original.)

Lieber omite referência ao contexto em que os autores usaram a expressão "deturpação". Embora esta omissão possa facilitar ao leitor mais apressado a concordância com as suas opiniões, ela dificulta o esclarecimento da questão tratada por Binder, Almeida e Monteau, no texto citado, e que foi retomada em outros textos (Almeida 1996; Binder 1997; Almeida e Binder 1996; Binder e Almeida 1998).

Um primeiro aspecto a ser esclarecido é o de que, em nenhum desses textos, os autores usam a expressão "deturpação" para referir suposta diferença entre causas encontradas na investigação de um acidente e causa esperada desse AT. Tal afirmação constitui-se mera invencionice de Lieber. Ao contrário dessa afirmação, os autores citados e os textos franceses de autores que criaram o método ADC destacam a importância de cuidados, durante a etapa de coleta de dados de uma análise com o método, de modo a evitar, por exemplo, a influência de opiniões prévias que 
dificultem a averiguação de outros possíveis fatores de natureza distinta daqueles a que o investigador está familiarizado.

A busca de causa esperada ou previamente definida é adotada em métodos de investigação baseados em questionários ou listas de perguntas fechadas. A análise de acidentes com o método ADC deve sempre se iniciar pela abordagem da situação de trabalho cotidiana, habitual, sem acidentes, de modo a oferecer um "padrão" a ser comparado com a descrição obtida da mesma situação, no momento do acidente. A reconstrução dessas duas situações lança mão de categorias de análise e questões abertas. Além disso, recomenda-se a condução do processo de modo sempre coletivo, ouvindo-se o acidentado, colegas de trabalho, chefias próximas, colegas que conhecem ou intervêm em componentes do sistema, consultando registros relativos aos diversos componentes do sistema (por exemplo: livro de registro de manutenção, registros de volume ou quantidades produzidas, cartões de ponto, planta física ou esquemas do ambiente físico, etc.), observando "in loco" as atividades e identificando as práticas adotadas, checando hipóteses aventadas, etc. Recomenda-se a adoção de processo coletivo de validação das informações coletadas e organizadas. Assim, a referência de Lieber à noção de causa esperada pode decorrer de desconhecimento do autor em relação a essas características do método ou de incompreensões acerca de categorias nele adotadas.

Ainda a propósito do mesmo tema, em outro texto, Almeida e col. (2000) comentam a impropriedade de questão formulada por técnico de segurança, durante discussão de apresentação do método. A pergunta era: "Para que me serve esse método, quando vou investigar um acidente que eu já sei por que aconteceu?" Ao adotar-se esse pressuposto, fecha-se a porta ao reconhecimento de alguma utilidade ou contribuição analítica em todo e qualquer método de investigação.

Para melhor esclarecer a questão de possíveis deturpações no uso do método $\mathrm{ADC}$, diferentemente do procedimento adotado por Lieber, de omitir referência às situações específicas, impõe-se sua especificação, a fim de que, em cada caso, possa ser formulada questão relativa à propriedade ou impropriedade de tal caracterização. Ao preferir formulação genérica e que falta com a verdade em relação à opinião 
escrita pelos autores, Lieber coloca nuvem de sombras acerca de seus próprios interesses na discussão. Vejamos essas situações:

a) A noção de variação é central no uso do método ADC. Leplat chegou a referir-se ao esquema, que é parte de uma análise com esse método como "árvore de variações”. Em nosso meio, há textos (Magrini e Ferreira s/d; Sindicato dos Químicos / Sindicato dos plásticos 1993) ditos de difusão do método ADC que não fazem qualquer referência nem a esse conceito nem a razões dessa sua omissão. A pergunta é: nesse tipo de situação, pode-se falar de deturpação no uso do método ADC? Os autores citados por Lieber consideraram que sim. Lieber furtou-se à discussão da questão específica.

b) Os criadores do método propuseram categorias de análise, notadamente a noção de atividade, a ser abordada em seus quatro componentes: indivíduo, tarefa, material e meio de trabalho. Os autores definiram também princípios fundamentais e diversas recomendações a serem adotadas no uso do método. Em nosso meio, Ferrão publicou artigo em que adota categorias diversas e desrespeita os princípios e regras citados. Binder e Almeida (1997) escrevem considerando o artigo de Ferrão um exemplo de distorção ou deturpação do método ADC. A pergunta é: nesse tipo de situação, pode-se falar de deturpação no uso do método ADC? Lieber furtou-se à discussão da questão específica.

c) A condução de análise de acidente, desde a coleta de dados, montagem da árvore, até a exploração ou interpretação do seu esquema, lança mão de categorias distintas daquelas da abordagem dicotômica ato inseguro/condição insegura ou da seqüência linear de eventos (ex-teoria do dominó), que tem sido associada com análises simplistas de acidentes e com a ênfase em conclusões que culminam em atribuição de causa, culpa e responsabilidade do acidentado pelo acidente sofrido. Em nosso meio, Lara Duca (1987) recomenda uso dessas categorias, na análise de acidentes com árvores de causas. A pergunta é: nesse tipo de situação, pode-se falar de deturpação no uso do método ADC? Os autores citados por Lieber consideraram que sim. Lieber furtou-se à discussão da questão específica. 
d) Estudos de experiências de implantação do método na realidade francesa revelaram: tipos de erros mais freqüentes na construção das árvores; deficiências no ensino do método; existência de dificuldades no domínio das regras do método por parte dos profissionais envolvidos; abandono de práticas de investigação que revelavam fatores gerenciais na origem de acidentes posteriormente desconsiderados nas estratégias de prevenção recomendadas no final da análise; limitações associadas com o tipo de contexto: empresa com política e práticas de segurança existentes ou inexistentes? implantação negociada desde o seu planejamento ou feita como decisão isolada de integrantes do setor de segurança? (Méric 1984; Milbergue e Favrot 1985; Pham 1989; Pham e Monteau 1989; Cuny 1995). Em nosso meio, o Ministério do Trabalho e Emprego, desconsiderando essas dificuldades, formalizou proposta, atualmente já revista, recomendando uso obrigatório do método ADC em momento em que a difusão do mesmo, seja na forma de cursos, seja na de literatura específica, era praticamente inexistente. A pergunta é: nesse tipo de situação, pode-se falar de preocupação acerca de possível deturpação na difusão e uso do método ADC? Os autores citados por Lieber consideraram que sim. Lieber furtou-se à discussão da questão específica.

Em seu pequeno parágrafo, Lieber ainda atribuiu aos "proponentes" do método ADC suposta "insistência em negar a legitimidade a qualquer outra perspectiva". Neste trecho, o autor não aponta nenhuma referência para fundamentar sua acusação, e a explicação mais simples para isso é que essa alegada insistência simplesmente não existe. Novamente, ao contrário de mais essa invencionice de Lieber, a opinião dos autores citados acerca do tema aparece em destaque, merecendo, inclusive, capítulo específico que se estende da página 71 à 85 do mesmo livro indicado por Lieber. Denominado "Indicações do método ADC", o capítulo trata de dificuldades afins à utilização do método que, na visão dos autores, contraindicam iniciativa como a do MTb de torná-lo obrigatório e de recomendar seu uso para a investigação de todo e qualquer tipo de acidente. Nesse e em outros textos, os autores ressaltam a existência de situações de segurança em que o uso do método seria desnecessário, ou seja, sem indicação técnica (Almeida 1996; Binder 1997). 
Do exposto, vê-se que Lieber se utilizou da expressão "deturpação", usada pelos autores, para tratar de assunto diverso. Ou seja, a leitura inicial que pode ser feita de discordância do autor em relação à existência de deturpações do método fica prejudicada pelo fato de Lieber nada escrever acerca das situações comentadas. Das palavras de Lieber acerca do tema da investigação de acidente, fica o registro de sua rejeição aos métodos e, em especial, ao ADC. No entanto, repita-se, apesar do uso da mesma palavra no início do parágrafo, ele não tratou da idéia que, aparentemente, queria abordar.

Para os fins deste estudo, não foram encontradas outras referências que permitissem reconsiderar a importância da possibilidade de deturpações no uso do método.

Considerando que, no Brasil, mantém-se em aberto a discussão relativa à reformulação da Norma Regulamentadora 5 e que, mesmo em literatura francesa acerca do método, particularmente aquela anterior à década de 90, observa-se a existência de desrespeito a princípios e/ou recomendações dos criadores do método (Assistance Publique / Hopitaux de Paris, 1988), parece importante a realização de estudos exploratórios acerca de experiências de difusão e implantação desse método, em nossa realidade, como o aqui descrito.

Os achados observados mostram que a preocupação dos autores citados em relação à possibilidade de deturpação do método se revela justificada. Uma das empresas investigadas tentou usar o método sem oferecer adequada formação prévia aos seus profissionais e sem atentar para a opinião de Monteau, para quem, na sua adoção, “[...] não se trata somente de introduzir uma modificação de procedimentos (de investigação), mas também de fazer evoluir as atitudes, de mudar os comportamentos e, finalmente, de introduzir uma mudança para que entre o "antes" e o "depois" a gestão da segurança seja diferente" (Chich 1984). O autor ainda complementa: "A introdução de tal mudança é uma operação complexa que requer um diagnóstico prévio do sistema que será alvo da intervenção". 


\subsubsection{Tipos de acidentes analisados com método de árvore de causas e indicação de uso desse método}

As investigações de acidentes analisadas neste estudo mostram que apenas 4 empresas do município ensaiaram utilização do método de árvore de causas (ADC), conforme mostrado na tabela 9. A empresa $D$, que fabricava aglomerados de madeira, elaborou esquemas para 71 acidentes; é empresa de grande capital, cuja produção se destina, majoritariamente, ao mercado internacional. Das duas metalúrgicas que usaram o método em 3 de seus acidentes, uma era grande, e a outra, média, com produção voltada, predominantemente, para o mercado interno. A empresa de distribuição de energia, no ano do estudo, era estatal, de grande porte, atuando em grande extensão do estado de São Paulo.

Em 55\% dos casos, os acidentes investigados eram de tipo 1 de Monteau, e os demais (44\%) eram de tipo 2. Isso se deve ao fato de a empresa D ter elaborado “árvores" para todos os 71 acidentes apresentados, a maioria dos quais era de tipo 1. Apesar disso, vale ressaltar que cerca de 30 dos seus acidentes eram de tipo 2, ou seja, incluíam fatores causais cuja exploração com o método ADC poderia ser "particularmente indicada", conforme discutido por Binder e col (1999). Nos demais casos, verificou-se que o acidente investigado na empresa distribuidora de energia era de tipo 1, tendo sido analisado em função da gravidade da lesão sofrida pela vítima.

A equipe de segurança de fábrica de aviões, sediada no município, entregou material didático, distribuído em curso de formação de integrantes de sua CIPA, que contemplava informações acerca do método $\mathrm{ADC}$ (vide item 4.4.1), porém não apresentou nenhum caso em que o mesmo tivesse sido utilizado.

Esses achados permitem inferir que, nas demais empresas em que houve tentativa de introdução do método, a saber, A, B, C e a fábrica de aviões, esse processo pudesse ser válido ou interessante, tendo em vista a natureza das atividades aí desenvolvidas. No entanto, as possibilidades de usufruto do uso do método mostram-se particularmente limitadas pelo tipo de concepção de acidente 
predominante nessas empresas (vide item 4) e pela ausência de domínio da técnica por parte dos seus integrantes.

\subsection{Concepções de acidentes do trabalho e sua investigação em materiais didático-educativos usados em empresas}

De acordo com o os achados já comentados no item 4.1 dos resultados desta tese, no ano de 1997, havia, no município de Botucatu, 64 empresas que, de acordo com as condições "existência de CIPA" e "ocorrência de acidente", poderiam ser parte do universo de estudo aqui abordado. Verificou-se que, em 03 empresas, a CIPA havia sido extinta e que, em 10, a empresa não existia mais (5 casos) ou não foi localizada (5 casos), apesar de busca através de visita ao endereço constante no Livro de Registro de comissões internas de prevenção de acidentes (CIPA) da Subdelegacia do Trabalho de Bauru, no ano de 1997, e de consulta em catálogo telefônico ou em lista de empresas cadastradas junto à Prefeitura Municipal e a diversos entrevistas em empresas visitadas. O banco de dados de acidentes do trabalho registrados perante a Previdência Social, através de comunicações de acidentes do trabalho referentes ao ano de 1997, também não incluía referência a nenhuma dessas 13 empresas.

Assim sendo, restavam 51 empresas, das quais 27 tiveram acidentes registrados, naquele ano. Esta condição foi verificada seja através de banco de dados organizado pelo Programa de Saúde do Trabalhador da Diretoria Regional de Saúde, DIR XI, Botucatu-SP., relativo a acidentes do trabalho registrados perante a Previdência Social, seja em consulta direta a representantes da empresa.

O quadro 4 mostra os tipos e quantidade de materiais didáticos e/ou destinados à prevenção de acidentes, entregues por representantes das empresas possuidoras de CIPA que tiveram acidente do trabalho registrado no ano de 1997, em Botucatu. A solicitação formulada referia-se a materiais que tivessem sido usados na empresa, no ano em questão. Todas as empresas foram recontactadas e confirmaram as respostas apresentadas. 


\begin{tabular}{|c|c|}
\hline $\begin{array}{r}\text { Quadro 4. Tipo e quantidade de materiais didáticos e de preven } \\
\text { acidentes entregues por representantes de } 27 \text { empresas possuidora } \\
\text { que tiveram acidente do trabalho registrado. Botucatu, SP., } 1\end{array}$ & $\begin{array}{l}\text { de } \\
\text { CIPA }\end{array}$ \\
\hline Materiais & QT \\
\hline Apostilas "Curso CIPA" (SENAC/SESI/SENAI ou adaptada) & 20 \\
\hline Outra apostila desenvolvida na empresa ou por consultoria & 2 \\
\hline Empresas que negaram uso de apostila ou material escrito ${ }^{9}$ & 5 \\
\hline Política de Segurança da empresa & 1 \\
\hline Normas ou documentos acerca de investigação de acidentes & 3 \\
\hline Árvore de causas & $3^{10}$ \\
\hline Outro & - \\
\hline Normas internas: procedimentos de segurança & 2 \\
\hline Normas internas relativas a "regras de ofício" & 3 \\
\hline Frases de segurança & 1 \\
\hline Cartazes de segurança & 2 \\
\hline Cartilhas de segurança & 2 \\
\hline Laudos técnicos & 3 \\
\hline
\end{tabular}

Na maioria das empresas (22), as apostilas usadas em cursos de formação de membros de CIPA foram as únicas referências escritas aos temas investigação e/ou prevenção de acidente. Em três dessas empresas, obteve-se também cópia de norma interna ou documento específico, sem registro de autoria, destinado a apresentar o método de árvore de causas. Esses três documentos foram usados na formação de integrantes de CIPA e/ou do corpo de técnicos do setor de segurança da empresa. Cinco (5) empresas que não possuíam Sesmt e eram assessoradas por empresas prestadoras de serviços na área de segurança negaram uso de apostila ou outro material didático, no curso de CIPA. Essas mesmas 3 empresas usaram cartazes e frases de segurança, sendo que, numa delas, as frases eram usadas mensalmente, em comprovantes de pagamentos.

Apenas uma empresa pública, que atuava no ramo da distribuição de energia elétrica, apresentou política de segurança escrita. Nesta empresa, este documento fora alvo de aprovação formal por parte de sua diretoria. Apenas duas empresas, essa do ramo de distribuição de energia elétrica e uma metalúrgica de médio porte,

\footnotetext{
${ }^{9}$ Duas empresas de construção civil assessoradas por mesma empresa apresentaram normas de segurança comentadas adiante.

${ }^{10}$ Uma das empresas que apresentou texto descritivo do método ADC não usou esta técnica em nenhum dos acidentes investigados, e uma empresa que a usou em um AT e indica sua utilização em apostila distribuída aos membros de CIPA não entregou nenhuma referência a esse método.
} 
apresentaram cartilhas de segurança. Além dessas duas empresas, uma terceira, do setor metalúrgico, também apresentou normas internas relativas a regras de ofício, por exemplo, procedimento para uso de máquinas e/ou ferramentas, que abordavam o tema da prevenção de acidentes.

De acordo com esses achados, chama a atenção o fato de a maioria das empresas não referir nenhuma ação contínua voltada para a incorporação de práticas de prevenção nas políticas, práticas gerenciais e rotinas adotadas nas mesmas. Com exceção da empresa pública com atuação no campo da distribuição de energia elétrica, em todas as demais empresas as práticas eventualmente existentes mostram caráter esporádico e de mera formalidade burocrática.

A seguir, descreve-se a abordagem dada ao tema da investigação de acidentes nos materiais entregues pelas empresas.

\subsubsection{Causas e investigações de acidentes em materiais didático- educativos usados na formação de membros de CIPA das empresas estudadas}

O material didático mais usado nos cursos de formação dos membros de comissões internas de prevenção de acidentes (CIPA) foi a apostila "CIPA", elaborada por profissionais ligados ao SENAC-SP. A estrutura e o conteúdo dessa apostila foram copiados em materiais adotados em empresas, sendo que, nesses casos, havia pequenas adaptações, parte das quais retirada de apostila intitulada "CIPA - Curso de treinamento", desenvolvida sob o patrocínio conjunto da Federação das Indústrias do Estado de São Paulo (FIESP), Centro das Indústrias do Estado de São Paulo (CIESP), Serviço Social da Indústria (SESI), Serviço Nacional de Aprendizagem Industrial (SENAI) e Instituto Roberto Simonsen (IRS).

Embora a apostila elaborada sob o patrocínio do grupo FIESP/CIESP/SESI/SENAI/IRS se refira aos acidentes como "decorrentes de uma multiplicidade de causas [... que exigiria ...] uma análise séria de fatores ambientais, humanos e materiais", pode-se afirmar que, regra geral, com exceção de duas 
apostilas em todas as demais, "o motivo" explícito ou implícito ao qual se atribui a ocorrência de "todos os acidentes" é

"porque se ignoraram determinadas regras e normas que os preveniriam ou porque não se analisou (ou analisou de forma deficiente) o meio ambiente".

A seguir, afirma-se que os acidentes estão ligados a dois tipos de causas:

- "fatores pessoais que levam à prática do ato inseguro e

- fatores do meio que proporcionaram o acidente, ou seja, a ocorrência de condição insegura" (negrito no original)

Ato inseguro seria "todo ato, consciente ou não, capaz de provocar algum dano ao trabalhador, a seus companheiros ou a máquinas, materiais e equipamentos, estando diretamente relacionado a falha humana. Características inerentes ao homem, como a teimosia, a curiosidade, a improvisação, o desafio, a autoconfiança, de acordo com cultura e a educação de cada povo, são fatores que comumente levam ao AI". Em apostila anterior, esses atos são definidos como "tudo aquilo que fazemos sem condições de segurança, durante a realização de nosso trabalho".

Condições inseguras são definidas como "Irregularidades ou deficiências existentes no ambiente de trabalho que constituem riscos para o trabalhador e bens materiais da empresa" ou ainda "são fatores de acidentes que (se) apresentam devido às falhas existentes nas condições do ambiente de trabalho, erros de projeto, planejamento incorreto ou omissão de requisitos essenciais de segurança, para manutenção de um ambiente físico livre de riscos de acidentes". Ressalta-se que condições inseguras são, em sua maioria, decorrentes da prática de atos inseguros.

As apostilas também definem Fator pessoal de insegurança: "Qualquer fator externo que leva o indivíduo à prática do ato inseguro: características físicas e psicológicas (insegurança, falta de treinamento, tensão, estresse, condições sociais, econômicas e financeiras, trabalho monótono e repetitivo) que contribuem para a ocorrência do acidente de trabalho" (grifos meus). 
Ao referir-se às investigações de acidente, afirma-se que "devem ser efetuadas de maneira objetiva, com base somente nos fatos, sem implicações disciplinares" (p. 22). A seguir, o texto apresenta elenco de regras básicas a serem adotadas na investigação, destacando-se:

- "Pesquisar situação anterior ao AT [...]

- Restringir-se aos fatos $[\ldots]$

- Procurar AI e CI que, na maioria dos casos, estão presentes ao mesmo tempo [...]

- Fazer recomendações [...], relatórios escritos [...]

- Determinar providências imediatas para evitar a repetição do acidente [...]

- Divulgar os resultados da investigação, pois seu valor é fundamentalmente educativo $[\ldots] "$.

Ainda de acordo com o texto, para atingir "seus objetivos - detectar, prevenir e corrigir atos e condições inseguras -“, a análise do acidente deveria ser pormenorizada, citando:

- “a fonte da lesão, isto é, o objeto que causou o acidente [...];

- $\quad$ a natureza da lesão (contusão, entorse, luxação, fratura [...];

- informações do encarregado e de outras testemunhas que possam levar à determinação de causas do acidente;

- Conseqüiências do acidente [...]”".

Apostila usada em empresa metalúrgica de grande porte adota a mesma estrutura e mudança na denominação de alguns dos conceitos comentados até aqui. Assim é que, em vez de utilizar a expressão "ato inseguro", adota "prática insegura", definida da mesma forma que ato inseguro: "ação praticada pelo homem consciente ou inconscientemente, colocando em risco sua integridade física, a de terceiros ou a de bens materiais, tendo a contribuição ou não da condição ambiente de insegurança". Em seguida, em vez de usar a expressão "condição insegura", utiliza "fator ambiental de insegurança", definida como "a condição do meio que 
causou o acidente ou contribuiu para a sua ocorrência" (pág. 7). O terceiro grupo de causas apontadas é o "fator pessoal”. Em negrito, há observação destacando:

“Para que ocorra um acidente de trabalho é necessário que haja pelo menos um dos grupos já apontados” (ou seja, "prática insegura", fator ambiental de insegurança ou fator pessoal acréscimo meu) (pág. 8).

Trata-se de empresa que utilizou o método ADC na investigação de 01 acidente comentado neste estudo. Após as mudanças de sinonímia citadas, apresenta dois acréscimos que merecem destaque.

Ao apresentar os princípios básicos da investigação de acidentes e doenças, condena, explicitamente, o uso das categorias ato inseguro/condição insegura, afirmando:

"Pelas características da prática nacional de análise e investigação de acidentes, convém não recomendar as conclusões do tipo - Ato Inseguro ou Condições Inseguras - as quais, pela generalidade, conseguem, no máximo, definir eventuais culpados mas nunca causas - estas sim elimináveis” (pág. 8).

Mais adiante, ao comentar cuidados a serem adotados numa investigação, informa:

"De posse das informações o grupo deverá iniciar o processo de análise, utilizando a metodologia da "árvore de causas" ou outro processo com maior complexidade [...]"(pág. 10).

$\mathrm{Na}$ continuidade do texto, não há descrição, seja do método $\mathrm{ADC}$, seja de outra técnica de investigação, e retoma-se a seqüência mantida na apostila usada nas demais empresas.

A abordagem heinrichiana é difundida na maioria das empresas e é também a que está presente em publicações brasileiras (Serviço Social da Indústria 1967; Associação Brasileira de Normas Técnicas 1975; Mccullough 1973; Mielnik 1976; Ribeiro Filho 1981; Zocchio 1980; Oushiro 1980; Brasil 1980, 1981, 1983; Clemente 1981; Saad 1981; Camargo 1988), notadamente aquelas difundidas pelo Ministério do Trabalho/Fundacentro, acerca dos acidentes ou da segurança no trabalho, conforme apontado por Almeida (1995). 
É interessante comparar os aspectos apresentados no item análise do acidente para ilustrar que a "descrição do acidente deve ser pormenorizada" (grifo meu) como aqueles apresentados na teoria dos dominós desenvolvida por Heinrich (1959), na década de 30. Os aspectos comentados na apostila foram reordenados de acordo com a sequiência dos dominós a que correspondem.

\begin{tabular}{|c|c|c|}
\hline \multicolumn{3}{|c|}{$\begin{array}{l}\text { Quadro } 5 \text { Comparação entre itens propostos para descrição de acidentes, em apostila distribuída } \\
\text { a membros de CIPA de empresas de Botucatu, SP., em 1997, e a sugerida na teoria dos dominós } \\
\text { de Heinrich. }\end{array}$} \\
\hline Análise proposta & Teoria dos Dominós (Heinrich) & Comentário \\
\hline Natureza da lesão & Lesão & Sem diferenças \\
\hline Conseqüências do acidente & Lesão & $\begin{array}{l}\text { Análise amplia descrição para } \\
\text { perdas diferentes da lesão }\end{array}$ \\
\hline Fonte da lesão & Acidente (origem da lesão) & Sem diferença \\
\hline $\begin{array}{l}\text { Informações que levem às } \\
\text { causas do acidente }\end{array}$ & Ato inseguro ou perigo mecânico & $\begin{array}{l}\text { Sem diferença, pois as causas } \\
\text { apontadas são os atos e as } \\
\text { condições inseguras }\end{array}$ \\
\hline- & Características da personalidade & Não abordada na análise \\
\hline- & Ambiente social e hereditariedade & Não abordada na análise \\
\hline
\end{tabular}

A observação do quadro 5 mostra que os aspectos enfatizados como correspondentes a descrição pormenorizada do AT, na verdade, representam redução, quando comparados com a seqüência linear de eventos proposta por Heinrich, na década de 30. Afinal, os passos citados correspondem, na prática, às 3 primeiras pedras do dominó de Heinrich, contadas a partir da lesão, e a quarta pedra desse dominó (características da personalidade) corresponde aos fatores pessoais de insegurança, omitidos na análise proposta.

Em seu estudo, Almeida (1996) mostra que essa mesma omissão aparece em publicação de Clemente (1981):

"Há referência aos fatores pessoais de insegurança como causas remotas dos atos inseguros, mas que só interessariam nessa qualidade e por isso, 'podemos deles prescindir, concentrando nossa atenção em suas conseqüências: os atos inseguros'.”

Segundo o modelo proposto, a descrição "pormenorizada" do acidente, na verdade, encerra-se precocemente. Tal interrupção foi apontada por Binder e col. 
(1997) como uma das falhas de investigações de acidentes realizadas em 3 empresas de grande porte, no estado de São Paulo. Este tipo de interrupção foi mostrado por Dodier (1994) e por Kouabenan (1999) como uma das características de investigações que buscam encontrar um culpado.

De modo mais abrangente, Almeida e col. (2000) consideram que a atribuição de culpa à vítima de acidente, no Brasil, pode estar associada com o uso de modelo oficial de investigação semelhante ao descrito.

Apenas 2 empresas apresentaram apostilas distribuídas a membros de CIPA diferentes da acima comentada. Uma delas, empresa metalúrgica em que houve duas tentativas de utilização do método ADC, apresentou texto que inclui tópico "Fatores determinantes de acidentes do trabalho" onde, em subitem intitulado "A procura das causas", pode-se ler:

"Os acidentes do trabalho são decorrentes de uma multiplicidade de causas. [que exigiria ...] uma análise séria de fatores ambientais, humanos e materiais".

A seguir, explicita-se concepção linear de acidentes:

“Essa multiplicidade pode ser representada por uma seqüiência de fatores chaves e não apenas pelos dois aspectos mais vulgarizados na análise dos riscos (atos e condições inseguras)." (segue-se desenho de 10 pedras de dominós enfileiradas e em que as 3 primeiras estão caídas e $4^{a}$ caindo.)

Nessa mesma apostila, seguem-se afirmações como:

"Muitas vezes é identificado apenas o fato mais próximo ao acidente e não o responsável determinante do infortúnio [...]"

"Os fatos não ocorrem ao acaso; eles sempre fazem parte de um contexto e surgem a partir de processos a ele relacionados."

"Quando um acidente ocorre [...] devemos [...] analisá-lo profundamente. [...] a finalidade da investigação não é a de procurar um culpado ou um responsável, mas encontrar as causas.”

O texto prossegue apresentando subitens idênticos aos mostrados na apostila previamente comentada: fonte da lesão, fator pessoal de insegurança, natureza da 
lesão e localização da lesão. Em seguida, apresenta-se exemplo de acidente em que o Sr. J sofre perfuração de olho, durante perfuração de um cano, com uso de uma furadeira elétrica portátil cuja broca estava com o fio gasto e quebra-se. A descrição informa que o $\mathrm{Sr} \mathbf{J}$ forçava a penetração da broca, quando teve sua atenção desviada por faíscas saídas de um ponto do cabo da extensão que apresentava rompimento, deixando a descoberto os fios condutores de eletricidade. Ao desviar a atenção, o Sr. $\mathrm{J}$ torce o corpo e força a broca, que se rompe e se projeta na direção de seu rosto.

O quadro 6 mostra a exploração do acidente apresentada na apostila:

\begin{tabular}{|c|c|c|c|}
\hline \multicolumn{4}{|c|}{$\begin{array}{l}\text { Quadro 6. Exploração de exemplo de acidente, mostrado em apostila de empresa do setor } \\
\text { metalúrgico. Botucatu, SP., } 1997 .\end{array}$} \\
\hline Atos perigosos & Condições perigosas & Causa imediata & Falhas na supervisão \\
\hline Improvisou uma escada & Óculos sujos e quebrados & $\begin{array}{l}\text { Não usou óculos de } \\
\text { segurança }\end{array}$ & $\begin{array}{l}\text { Não obrigou o uso de } \\
\text { óculos de segurança [...] }\end{array}$ \\
\hline $\begin{array}{l}\text { Forçou a penetração da } \\
\text { broca }\end{array}$ & Caixas no lugar de escada & & conforme determinação \\
\hline Não usava óculos & Broca com o fio gasto & & \\
\hline $\begin{array}{l}\text { Não examinou o cabo } \\
\text { condutor de eletricidade }\end{array}$ & $\begin{array}{l}\text { Condutores do cabo com } \\
\text { os fios expostos }\end{array}$ & & \\
\hline
\end{tabular}

A leitura do quadro revela concepção de acidente semelhante à mostrada na apostila anteriormente comentada: "desrespeito a regras e normas que os preveniriam ou porque não se analisou (ou se analisou de forma deficiente) o meio ambiente". As conseqüências dessa concepção estão bem ilustradas no exemplo, destacando-se que:

a) A noção de ato inseguro, aqui apresentada como "ato perigoso", embute interpretação acerca de ação do trabalhador que implica em atribuição de comportamento negativo ou erro. Além disso, como se individualiza a análise, as razões de "contexto e de processos relacionados" perdem importância e deixam de ser investigadas, como se vê no quadro.

b) Raciocínio semelhante foi aplicado em relação às condições inseguras ou perigosas, que, uma vez identificadas, foram consideradas suficientes e não tiveram suas origens investigadas. 
c) Idem em relação à "falha de supervisão". Esta ilustra ainda abordagem tradicional de segurança, segundo a qual comportamentos faltosos devem ser vigiados e corrigidos, se necessário, até com o uso de medidas disciplinares.

d) A causa imediata mostrada no quadro revela erro conceitual grosseiro. $\mathrm{O}$ uso de óculos de segurança em situação semelhante poderia, eventualmente, evitar ou diminuir a gravidade da lesão, mas não do acidente em questão.

O texto revela que, na empresa em questão, há tentativa de introdução de concepção multicausal de acidente, seja na forma de sequiência linear, seja na forma de rede de interação de múltiplos fatores, como se vê em material específico acerca do método ADC. No entanto, estes se sobrepõem a conceitos que expressam concepção paucicausal de acidente resumida em atos e condições inseguras renomeada como atos e condições perigosas.

O texto de apresentação do método de árvore de causas usado na empresa tem apenas 4 páginas e foi elaborado por técnico de segurança da mesma. O quadro 7 mostra descrição sucinta do texto e comentário acerca do mesmo.

As razões dessa situação ambígua não foram exploradas neste estudo. É possível que reflitam o acesso de profissionais da empresa a novos conhecimentos e tentativa acrítica de incorporação dos mesmos nos materiais didáticos e práticas de segurança adotados. A falta de crítica citada refere-se, seja a dificuldades de percepção, por parte dos profissionais da empresa, das diferenças de concepções de acidente adotadas nas 3 abordagens esboçadas, seja a dificuldades de compreensão e domínio das regras do método ADC, seja a resistências ao abandono da concepção heinrichiana, hegemônica até então.

Oliveira F (1997) encontrou situação semelhante na empresa que estudou. Discutindo tentativa de implantação de método ADC em contexto historicamente marcado pelo uso da abordagem heinrichiana, afirma: 
“[...] essa nova forma de pensar o acidente é estranha à "cultura" da empresa, da mesma forma que a apostila confeccionada não corresponde às práticas do setor de segurança no trabalho, o que vem ocasionando sobreposições semânticas nos discursos de engenheiros, técnicos e cipeiros ...” (pág 102).

\section{Quadro 7. Resumo de texto que apresenta método de árvore de causas, distribuído em empresa metalúrgica, e comentário acerca de seu conteúdo. Botucatu, SP., 1997.}

\begin{tabular}{|c|c|}
\hline Texto da empresa & Comentário \\
\hline $\begin{array}{l}\text { Pág. } 1 \text { - Descrição do método: afirma-se } \\
\text { que o acidente é "pluricausal, [...] não é só } \\
\text { consequiência de infração a norma de } \\
\text { Segurança, é um sintoma do mau } \\
\text { funcionamento do sistema". Cita fases de, } \\
\text { levantamento dos fatos, ordenação dos } \\
\text { fatos, busca de medidas preventivas e } \\
\text { priorização dessas medidas. }\end{array}$ & $\begin{array}{l}\text { A descrição é sumária. Merecem destaque: } \\
\text { - Apresenta AT como resultante de infração a norma de } \\
\text { segurança idealizada. } \\
\text { - A atividade e seus componentes não são apresentados. Os } \\
\text { símbolos gráficos criados pelos autores do método não são } \\
\text { apresentados. } \\
\text { - Não há referência ao conceito de variação, básico para os } \\
\text { criadores do método. } \\
\text { - Apresenta etapa de ordenação dos fatos como equivalente à de } \\
\text { montagem da árvore, omitindo referência aos cuidados afeitos } \\
\text { à definição e denominação dos fatores. Não há referência às } \\
\text { regras lógicas na montagem da árvore. }\end{array}$ \\
\hline $\begin{array}{l}\text { Pág. } 2 \text { - Roteiro de investigação de } \\
\text { acidentes que recomenda levantar a } \\
\text { atividade em que ocorreu o acidente, a } \\
\text { parte do corpo afetada, o agente da lesão, o } \\
\text { acidente tipo, os atos inseguros, as } \\
\text { condições inseguras e os fatores pessoais }\end{array}$ & $\begin{array}{l}\text { Propõe categorias estranhas ao método, particularmente: } \\
\text { - } \quad \text { atos inseguros, } \\
\text { - } \quad \text { condições inseguras, e } \\
\text { - } \quad \text { fatores pessoais do acidentado. }\end{array}$ \\
\hline Pág. 3 - Descrição de um acidente & $\begin{array}{l}\text { Não organiza lista de fatores, não usa classificação de acordo com } \\
\text { categorias indivíduo, tarefa, material e meio de trabalho, não } \\
\text { classifica fatores segundo a sua habitualidade. }\end{array}$ \\
\hline Pág. 4 - Esquema ou árvore desse acidente & $\begin{array}{l}\text { O desenho é montado de baixo para cima e não no sentido } \\
\text { convencionado pelos criadores do método. } \\
\text { Os sinais gráficos propostos para classificação de fatores (variação } \\
\text { e habituais) não são usados e não há setas indicando sentido das } \\
\text { relações entre fatores do esquema. } \\
\text { Não há explicação para o uso de negações e interpretações que, } \\
\text { segundo as recomendações dos criadores do método, não deveriam } \\
\text { ser usados no esquema. } \\
\text { Há diversos erros de relação lógica entre fatores representados na } \\
\text { árvore. }\end{array}$ \\
\hline
\end{tabular}

Mais adiante o autor acrescenta:

“[...] a tentativa de introdução de um novo modelo de compreensão dos acidentes revela quão profundamente a visão hegemônica está enraizada nas formas de apreensão da realidade dos membros dessa empresa, de modo que as propostas do método de árvore de 
causas são interpretadas à luz da dicotomia atos inseguros - condições inseguras” (pág 104).

A segunda empresa a apresentar material elaborado por sua própria equipe de segurança foi instituição pública, posteriormente privatizada, que atua na distribuição de serviços, na região. Neste estudo, esta foi a única empresa a apresentar cópia escrita de materiais diversos, ilustrando existência de política e setor responsável pelo seu desenvolvimento com vida própria. Os materiais entregues foram:

Resolução de Diretoria - política e diretrizes empresariais de SST.

Normas:

N0051280 - Acidente do trabalho (Sistema de recursos humanos)

N0051173 - Organização das CIPA

NPR 3001 - Metodologia árvore das causas

NPR 3002 - Acidente do trabalho (Norma de Engenharia de Segurança do Trabalho)

PPRA

Normas e Procedimentos de SMT para empreiteiras

Jornal interno "Saúde e Segurança", edição especial, 07/05/90 - Em rede desligada 5 são os passos básicos da segurança

Panfleto colorido (formato de bolso) - Em rede desligada 5 são os passos básicos da segurança (mesmo texto do Jornal)

Folheto (formato de bolso): "Responsabilidades na prevenção de acidentes"

Calendário anual (formato de bolso)

Ano 90 - Temas "Respiração artificial" e "Massagem cardíaca"

Cartilhas (coloridas, apresentação bem cuidada): 
Manual de Segurança no Trânsito

Manual de Segurança no Escritório

Manual de Segurança para Eletricistas

Informe interno "Segurança" (set e out 98)

Apostila: Curso Membros de Cipa

A lista de textos mostra que a empresa se preocupou com a elaboração de material informativo que trata, especificamente, de temas considerados afins à sua realidade, ou seja, de riscos à saúde e medidas de primeiros socorros a serem usadas no manejo de alguns deles.

A Norma "N0051280 - Acidente do trabalho (Sistema de recursos humanos)" cita grupo de investigação e análise de acidentes (GIAA) e explicita responsabilidade da gerência imediata de "solicitar a investigação do acidente" imediatamente após a sua ocorrência. Em nota complementar, esclarece:

“Quando se tratar de acidente de causas pouco relevantes, com ou sem danos materiais ou ainda acidentes de pequena gravidade, sem afastamento, poderá, a critério da gerência em conjunto com o profissional de segurança do trabalho da área, ser dispensada a investigação pelo GIAA. Neste caso o "Relatório de Investigação de acidente" deverá ser elaborado pelo membro da CIPA pertencente ao GIAA”.

A "NPR 3002 - Acidente do trabalho", norma da Engenharia de Segurança do Trabalho, estabelece procedimentos a serem adotados na vigência de acidente do trabalho. Determina-se o uso da "metodologia árvore de causas" para os acidentes a serem investigados pelo GIAA. A metodologia é descrita em norma específica, “NPR 3001", que inclui anexo a ser preenchido para posterior envio de relatório de investigação.

A norma NPR 3002 estabelece procedimentos a serem adotados (descritos no contrato de prestação de serviços anexo às concorrências abertas pela empresa) no caso de acidentes do trabalho ocorridos com empregados de empreiteiras, incluindo comunicação interna de acidente do trabalho. 
A apostila "Curso Membros de CIPA" apresenta síntese da apresentação do método ADC feita na publicação específica (NPR 3001). Nessa síntese, não há apresentação do conceito de atividade, nem de seus componentes - indivíduo (I), tarefa $(\mathrm{T})$, material $(\mathrm{M})$ e meio de trabalho (MT). Também não há referência ao conceito de variação considerado básico pelos criadores do método.

A metodologia é descrita em norma própria, NPR 3001, em texto de 21 páginas. As páginas iniciais apresentam como objetivo "Estabelecer o procedimento para realização da investigação de acidentes, pela Metodologia Árvore das Causas”, incluem definições usadas e detalham aspectos da formação do grupo de investigação e análise de acidentes (GIAA), atribuições das diversas gerências envolvidas e do coordenador do GIAA. Definem papel de orientador da "correta aplicação da metodologia dentro dos padrões e princípios preestabelecidos", atribuindo-o aos profissionais de segurança do trabalho.

Adiante, propõe-se usar o método para investigar "todos os acidentes do trabalho com afastamento e outros acidentes" que as gerências e ou profissional de segurança envolvido julgarem necessário.

Após isso, na $6^{\text {a }}$ página do documento, inicia-se apresentação da técnica, incluindo:

- Recomendações iniciais de eliminar: a) "[...] diferenças hierárquicas no grupo”, b) “qualquer busca de 'responsabilidade' ou culpa [...] abolindo os termos "ato inseguro" e "condição insegura" para a conclusão de um acidente do trabalho".

- Orientação relativa a cuidados a serem adotados na coleta de dados.

- Comentário: Não refere os conceitos de atividade e seus componentes indivíduo, tarefa, material e meio de trabalho.

- Sob o título “ordenação dos fatos”, são apresentados os símbolos gráficos relativos a representação de fatos habituais ou permanentes, variações ou eventuais e das configurações possíveis nas relações entre fatos. 
- Comentário: Não são incluídos os símbolos relativos à dúvida sobre a natureza do fato (quadrado com círculo em seu interior), nem relativo à indicação de participação ou contribuição de fato não identificado na investigação (interrogação), nem à configuração denominada sobredeterminação. Não há explicações relativas ao conceito de variação e nem da importância que lhe é atribuída pelos criadores do método como "fio de meada" da reconstrução do AT.

- A elaboração da árvore é apresentada sucintamente. Há sugestão de questões relativas à identificação de origens de fatos "conseqüentes", interrogando "causa" no singular e afirmando: "é importante seguir com a análise até identificar problemas relacionados a treinamentos, metodologia, equipamentos, instalações, meio ambiente, etc".

- Comentário: desconsideram-se as razões, inclusive de natureza lingüística, que levaram os criadores do método a sugerir as questões padronizadas e direciona-se a análise para resultados preestabelecidos, fato que é contraditório com os preceitos do método amplamente reconhecido pela natureza aberta de sua coleta de dados.

- Sugestão de critérios a serem usados com vistas à exploração da árvore para os fins de prevenção.

- Sugestão de modelos de relatório, de análise qualitativa das árvores, de seguimento das medidas sugeridas na análise e de divulgação da norma.

Conforme a própria extensão da apresentação sugere, a experiência de implantação do método ADC nessa empresa diferencia-se radicalmente daquela das demais. É preciso observar que, neste estudo, a análise do domínio das regras do método por parte de seus técnicos limita-se àqueles que atuam na região do município estudado e que, no ano de 1997, a metodologia foi aplicada apenas $1 \mathrm{vez}$, limitando o alcance dessa análise.

A leitura da norma que determina sua aplicação na empresa revela, ao lado de série de cuidados recomendados em estudos de implantação do método em outras realidades, a presença de indícios de desconhecimento de regras do método, de 
minimização do grau de dificuldade relativo ao seu adequado domínio técnico, já denominado na literatura de "dificuldades intrínsecas" ao método (Pham 1989), e de abordagem burocrática das "dificuldades extrínsecas" ou relativas à implantação de medidas de prevenção que sugerem mudanças nas práticas de gestão da produção adotadas na empresa (Pham 1989).

Entre os aspectos positivos, citam-se:

- a formalização da implantação do método, incluindo definições de atribuições e a figura do orientador;

- as recomendações relativas à coleta de dados;

- as recomendações relativas à análise qualitativa das árvores e acompanhamento das medidas propostas.

É importante salientar que parte desses aspectos parece ter alcance limitado, tendo em vista imprecisões de sua própria apresentação, como, por exemplo, a ausência de referência às medidas ou passos a serem seguidos com vistas à "eliminação de diferenças hierárquicas no grupo". Considera-se fundamental que o clima, no grupo de trabalho que conduz a análise, seja de ampla liberdade, mas a construção desse espaço é processo que exige muito trabalho. $\mathrm{O}$ abandono das concepções de ato e condição insegura, assim como da prática de busca de responsável pelo acidente, podem auxiliar, mas, como discutido anteriormente, as resistências de concepções hegemônicas persistem e não podem ser superadas por "decreto". Na empresa em questão, até o período anterior a este estudo, os resultados de investigações de acidentes que indicavam responsabilidade do acidentado eram usados como base para punições administrativas da vítima.

Da mesma forma, a mera criação da figura do orientador não implica a existência de suporte adequado. Os erros incluídos na norma que descreve o método e na árvore elaborada por técnico da empresa, no município estudado, corroboram essa idéia. 
Em cinco empresas, não se conseguiu acesso à apostila usada nos cursos de CIPA. Em três delas, o treinamento e assessoria para investigação de acidentes e preenchimento dos documentos administrativos, de envio obrigatório à representação do Ministério do Trabalho e Emprego, eram oferecidos por um mesmo técnico de segurança, e, nas demais, empresas de construção civil de mesmo grupo, a assessoria era oferecida por empresa especializada na oferta desse tipo de serviço. No caso do técnico de segurança, este alegou não utilizar nenhuma apostila ou material de base e, no caso da empresa, recebeu-se cópia de seis documentos, sendo dois procedimentos - um deles relativo à investigação de acidentes -, duas normas e duas circulares.

O documento "Procedimentos para investigar os acidentes do trabalho (no interior do canteiro de obras)" é preenchido em menos de uma página e inclui oito afirmações, especificando necessidade de ida ao local do AT, de conversa com testemunhas e de registro com nome de testemunhas, que deveria servir de base para preenchimento do anexo II da NR 5 por parte da secretária da CIPA. Não há nenhuma referência a cuidados técnicos ou procedimentos relativos à prática de investigação do acidente.

Aspecto a destacar nessas cinco empresas é o fato de sua ligação com assessorias de segurança. Esses tipos de assessorias cresceram no mercado, nos últimos anos, particularmente após mudanças de normas regulamentadoras emitidas pelo MTE, em especial as que tratam de programa de controle médico de saúde ocupacional (PCMSO) e programa de prevenção de riscos ambientais (PPRA). A pequena amostra da atuação dessas assessorias, evidenciada neste estudo, sugere que, no município de Botucatu, parte delas desenvolva atuação oportunista, sem qualquer preocupação com a qualidade técnica.

Outro aspecto que merece destaque é o fato de nenhuma das publicações citadas abordar o tema da definição de responsabilidade, no caso de acidentes do trabalho. Os treinandos, que até aquele momento deveriam participar de investigação de acidente e referendar o preenchimento de instrumento obrigatório, em cuja conclusão constava questionamento direto acerca da responsabilidade pelo evento, não recebiam nenhuma informação que os auxiliasse nessa tarefa. 
Leplat (1997) apontou as dificuldades presentes na definição de responsabilidades individuais em evento cuja origem envolve rede de múltiplos fatores em interação. Wilpert (1997) faz eco com esse último autor, interrogando onde encontrar critérios para alocar responsabilidades de modo justo, em situação com grande quantidade de atores e fatores que contribuíram para o acidente. Kouabenan (1999) mostrou que a definição de responsabilidade é mais complexa que aquela de causa e destacou que, ao se discutirem as relações entre causalidade humana e responsabilidade, leva-se em consideração se a "causa" poderia ser controlada pela pessoa implicada e possíveis efeitos de circunstâncias atenuantes ou não.

\subsubsection{Materiais dedicados à prevenção de acidentes}

No estudo conduzido em Botucatu, verificou-se que apenas duas empresas apresentaram materiais educativos baseados em orientações específicas acerca de regras da arte, seja no desenvolvimento de algumas atividades, seja na utilização de algumas ferramentas e/ou equipamentos. A primeira foi uma empresa pública, com atuação na distribuição de energia, que providenciava folhetos e/ou cartões (formato de bolso), jornais internos e livretos com instruções específicas, seja em relação a regras da arte em diferentes tarefas, seja em relação a procedimentos de primeiros socorros a serem adotados em alguns tipos de acidentes próprios da atividade principal da empresa. A segunda foi uma metalúrgica de médio porte, que providenciava a elaboração de suas próprias apostilas para membros de CIPA, treinamentos no uso de ferramentas manuais, equipamentos de solda, atividades envolvendo eletricidade, transporte e movimentação de materiais; utilizava também histórias em quadrinhos e cartazes de segurança.

O uso de orientações específicas para a ação foi apontado por Levanthal e col. (1965) como condição necessária, mas não suficiente, para a implementação de mudanças de comportamento com vistas à prevenção de acidentes.

A existência de uma "cultura do ofício" dos trabalhadores, reconhecida pelos integrantes dos níveis hierárquicos superiores da empresa, seria favorecida por iniciativas de formação específica e foi apontada por Carpentier-Roy e col. (1998) 
como potencialmente estimuladora da condição de pertencente e integrante do grupo. Quanto maior esse sentimento, mais eles se sentiriam interpelados pelas atividades conjuntas de prevenção e mais tenderiam a apoiar as ações dos comitês paritários de saúde e segurança aí existentes.

Segundo Dejours (1993 e 1997) e Dejours e Abdoucheli (1994), o reconhecimento do trabalho realizado pelo trabalhador, por parte de seus colegas ou pares, estaria na base da constituição das "regras de ofício" e seria fundamental para a coesão das equipes e para a confiabilidade humana na atividade.

A inexistência de iniciativas voltadas para o reconhecimento da importância dessas regras de ofício e da coesão dos grupos de trabalho, nas empresas estudadas, soma-se ao fato de que a maioria das medidas propostas nas investigações de acidente sugere, genericamente, mudanças de comportamento dos acidentados, principalmente aquelas de tipo prestar mais atenção.

Não era objetivo deste estudo explorar, entre os trabalhadores das empresas estudadas, a existência ou não de condição de pertencente a um grupo. No caso da empresa de distribuição de energia, há, aparentemente, reconhecimento da natureza especializada dos eletricistas e relativa estabilidade no emprego, que facilitariam o desenvolvimento de identidades singulares dos profissionais integrantes desse grupo. No entanto, no caso da empresa metalúrgica, observou-se que, apesar da existência do material citado, persistiam problemas como os seguintes:

a) A maioria das medidas apresentadas nos diversos textos é redigida com uso de verbos na $3^{\text {a }}$ pessoa do singular, que prescrevem ações a serem feitas pelos trabalhadores. Reforça-se, desta maneira, a prática de atribuição de culpa, segundo a qual os acidentes ocorrem na vigência de descumprimento de regras por parte do acidentado. Além disso, no caso de recomendações relativas a cuidados a serem adotados, desconsideramse as possibilidades de os trabalhadores não reconhecerem como de risco as situações e não terem esboçado qualquer mudança de atitude ou ação que implique em autoproteção no trabalho. 
b) A prescrição adotada na empresa desconsidera a possibilidade de inexistência de condições ótimas para a realização das ações prescritas, a possibilidade da inadequação dessas ações às condições de organização do trabalho real na empresa e a de, na vigência do uso da medida prescrita, o sistema tornar-se pouco tolerante a mudanças, ou seja, ter a sua segurança dependendo, exclusivamente, do desempenho do indivíduo na tarefa. Em alguns momentos, recomenda-se recorrer ao chefe imediato, na vigência de dúvidas e/ou dificuldades. A busca de recursos e/ou organizações do trabalho alternativas que aumentem a tolerância do sistema a desvios e variações, tornando-o mais seguro, é desconsiderada. A segurança adviria do apego ou adesão do trabalhador às normas e prescrições "corretas".

c) As referências a "causas" de problemas potencialmente acidentogênicos são feitas na forma de lista, desconsiderando possíveis inter-relações de fatores, no mundo do trabalho, e sem exploração de suas origens, ou seja, estimulando a interrupção da análise com a identificação "da causa" listada. Esta abordagem contribui para manter a segurança como compartimento ou setor estanque, externo à missão de produção do empreendimento, enfim, não reconhecida como parte integrada na totalidade da empresa. Esta condição, por sua vez, tende a dificultar o desenvolvimento de clima de incentivo e busca constante da autoprevenção.

d) Todos os riscos, independentemente de sua freqüência, gravidade ou demais características, são apresentados da mesma maneira, ou seja, como se tivessem sempre o mesmo peso ou significado. Como decorrência, riscos de explosões são apresentados do mesmo modo que riscos de arranhões em imperfeições do cabo de uma ferramenta manual. Essa condição soma-se à inexistência de critérios a serem utilizados na definição de prioridades, em cada situação ou setor. 
A maioria absoluta das abordagens presentes nos materiais desconsidera a forma como a literatura relativa aos comportamentos face ao perigo no trabalho vem abordando a questão.

Este aspecto parece contribuir para facilitar a aceitação da abordagem simplista presente, seja na compreensão do fenômeno acidente, seja na de medidas de prevenção.

\subsubsection{Frases e cartazes de segurança: estímulo ao medo e atribuição de culpa}

Apenas 2 empresas entregaram material relativo à utilização de mensagens de prevenção difundidas através de cartazes, comprovantes de pagamento ou como destaques em apostilas e materiais didáticos.

Não há diferenças significativas entre as frases usadas em comprovantes de pagamento, caso de uma empresa do município, e aquelas usadas em cartazes de segurança, conforme se pode observar nos quadros 8 e 9.

Observa-se que:

- A maioria das frases transfere, implícita ou explicitamente, a prevenção para o controle do trabalhador, seja por meio de afirmações genéricas ("proteja-se", "pratique segurança"), seja por meio do incentivo à obediência a regras/normas de segurança e/ou ao uso de equipamentos de proteção individual.

Comentário: Toda ênfase da identificação ou definição de causas é posta em comportamentos faltosos do trabalhador, identificados pela comparação de suas ações com prescrições ou normas da empresa, abstraindo-se trabalho real ou qualquer referência às exigências de sua tarefa e condições operacionais impostas. Reitera-se idéia de que os acidentes resultam do "desrespeito a regras e normas que os preveniriam ou porque não se analisou (ou se analisou de forma deficiente) o meio ambiente" e/ou da não-utilização de EPI.

- A atribuição de culpa a características do caráter ou intrínsecas do trabalhador aparece de modo direto em frases que atribuem o acidente a 
distrações e/ou indisciplinas do trabalhador (esta originando comportamento indesejado, por exemplo, correr).

\begin{tabular}{|l|}
\hline $\begin{array}{c}\text { Quadro 8. Frases de segurança, usadas em comprovantes de pagamentos } \\
\text { de empresa metalúrgica de grande porte. Botucatu, SP., 1997. }\end{array}$ \\
\hline O preço do acidente é sempre alto. \\
\hline Os acidentes não avisam - Proteja-se. \\
\hline O acidente está a sua espera - Proteja-se. \\
\hline Não brinque com a vida. Proteja-se. \\
\hline Prevenir acidentes é dever de todos. \\
\hline Toda hora é hora de segurança. \\
\hline Na luta pela vida, sua melhor arma é a segurança. \\
\hline Para estar aqui amanhã. Pratique segurança hoje. \\
\hline Pratique segurança: hoje, amanhã e sempre. \\
\hline Todos merecem viver - Pratique segurança. \\
\hline Nós confiamos em você. Pratique Segurança sempre. \\
\hline CIPA e você para uma segurança melhor. \\
\hline Leve segurança para casa. \\
\hline Segurança é o melhor caminho. \\
\hline Trabalhador - respeite as normas de segurança. \\
\hline Motoqueiro: utilize o capacete de proteção. \\
\hline Motorista consciente utiliza o cinto de segurança. \\
\hline Faça da ordem e limpeza um hábito. \\
\hline Peça ajuda para cargas pesadas e desajeitadas. \\
\hline Não utilize ferramentas em mau estado. \\
\hline As ferramentas serão seguras se você souber usá-las. \\
\hline As distrações causam acidentes. \\
\hline O disciplinado não corre, anda. \\
\hline
\end{tabular}

- O acidente é referido como ameaça em si ou que se expressa por suas conseqüências nefastas.

- O estímulo ao medo aparece em diversas frases, sem a utilização de representações realistas de lesões. Estas são sugeridas por meio de desenhos/esquemas ("A eletricidade tem um choque terrível"), frases 
fortes (“Uma queda é mortal”), ou referências à sensibilidade de estruturas que podem ser afetadas (“Seus ouvidos são sensíveis. [...] Proteja-os”).

\begin{tabular}{|l|}
\hline Quadro 9. Frases usadas em cartazes de segurança, em empresas de Botucatu, SP., 1997. \\
\hline \multicolumn{1}{|c|}{ Sobre a ocorrência de acidentes em geral } \\
\hline ACIDENTES não acontecem simplesmente. Existe sempre uma causa. \\
\hline Limpeza e organização / proteção contra quedas / armazenamento de materiais \\
\hline NÃO SUBA PELO ANDAIME. Uma queda é mortal. USE A ESCADA. \\
\hline NÃO IMPROVISE! ... Utilize o cinturão de segurança. \\
\hline SEJA TEIMOSO COM OS CINTOS DE SEGURANÇA. Use-os sempre. \\
\hline PREVINA UMA QUEDA. Se você derrubou algo, apanhe-o. Se você derramou algo, enxugue-o. \\
\hline MANTENHA LIMPO AQUI COMO EM SUA CASA. \\
\hline Empilhamento mal feito só traz dores de cabeça. \\
\hline \multicolumn{1}{c|}{ Proteção no trabalho com eletricidade } \\
\hline ELETRICIDADE: é para eletricista. \\
\hline Homens que conhecem a ELETRICIDADE RESPEITAM-NA. \\
\hline $\begin{array}{l}\text { A eletricidade tem um choque terrível. } \\
\text { Feche ou desligue a chave antes de fazer consertos. }\end{array}$ \\
\hline Não puxe pelo fio. (Esquema mostra trabalhador puxando ferramenta manual.) \\
\hline Limpeza e manutenção de máquinas \\
\hline CUIDADO. Não limpe, lubrifique ou repare máquina em movimento. \\
\hline Ao trabalhar com furadeira, NÃO USE LUVAS. \\
\hline Quando ouvidos ruão sensíveis. Os ruídos são perigosos. Proteja-os. \\
\hline Assim não. Use-os. (Esquema (esquema com protetores em ouvidos), não aqui (esquema com protetores no pescoço). \\
\hline
\end{tabular}

Segundo Levanthal e col. (1965), o despertar de emoções como o medo seria necessário para mudança em atitudes e em comportamentos. Além disso, receber informações específicas influenciaria o estado emocional dos indivíduos, inibindo certos estados de medo. Os efeitos do medo se dissipariam rapidamente no tempo e,

\footnotetext{
${ }^{11}$ As letras maiúsculas aparecem como tal nos cartazes.
} 
embora ensejassem mudança de atitude de entrevistados, não conseguiriam gerar mudanças no comportamento dos trabalhadores.

A utilização de mensagens que buscam atemorizar, culpar e/ou reforçar proibições em cartazes de segurança é mostrada por Davillerd (1998), na França.

Segundo a "teoria da motivação da proteção" ("protection motivation theory"), as mudanças associadas ao estímulo do medo dependeriam muito mais dos processos cognitivos de avaliações das informações comunicadas acerca da nocividade e probabilidade do efeito e da eficácia das medidas preventivas sugeridas do que do estado emocional de medo (Rogers e Mewborn 1976).

As prescrições e normas abordadas pela segurança parecem pertencer a um mundo que marcha em paralelo àquele da produção. E, mesmo diante de sua fragilidade técnica, persistem intocadas. Tomando-se, por exemplo, frases como "Não suba pelo andaime. [...] Use a escada", "Seus ouvidos são sensíveis. Os ruídos são perigosos. Proteja-os", "Não utilize ferramentas em mau estado" ou "Peça ajuda para cargas pesadas e desajeitadas”, verifica-se que as mesmas não questionam a existência da situação de base, respectivamente, um andaime que permite acesso por escalada, o ruído perigoso, a ferramenta em mau estado, a movimentação manual de carga pesada e desajeitada.

Além de apresentar os acidentes como resultado do "desrespeito a regras e normas que os preveniriam", as opiniões mostradas nas frases citadas sugerem que esse desrespeito teria origens em características dos próprios acidentados, em particular, sua indisciplina. McKenna e col. (1991) e Kouabenan (1999) lembram que, às vezes, os comportamentos dos indivíduos, no trabalho, são descritos como irracionais. Porém, essa suposta irracionalidade seria apenas aparente. Afinal, esses indivíduos poderiam receber feedback positivo de seus comportamentos perigosos, por exemplo, não se acidentando, reforçando sua crença de que os acidentes acontecem apenas com os outros. Com o tempo, a aceitação tácita ou tolerância dessas práticas, nas empresas, pode passar a constituir-se em mais um dos fatores que explicam a persistência das mesmas. 
A importância da ilusão de otimismo ou de controle foi relativizada por Kouabenan (1999c), para quem fatores relacionados ao uso da medida e à adesão de grande quantidade de pessoas à sua adoção poderiam ser mais importantes do que ela. Nas palavras do autor, "essas diferentes informações podem ser utilmente exploradas para informar e formar as pessoas sobre os riscos, e para compreender e prever as reações do público [...]. As campanhas devem incluir judiciosamente um débil, mais um real nível de medo ou de ameaça. Uma ameaça exagerada pode suscitar reações de defesa e de fuga ("d'évitement") tais como a ilusão de superioridade" (p. 228). Mais adiante, ao defender a incorporação da ilusão ou viés defensivo nas mensagens de prevenção, Kouabenan (2000d) concorda com opinião de McKenna: “o efeito das campanhas de prevenção através da mídia pode ser contraditado pela ilusão da maior parte das pessoas que são tentadas a considerar que essas campanhas dirigem-se antes de tudo aos outros que seriam mais vulneráveis do que eles" (Kouabenan 2000d, p. 240).

$\mathrm{Na}$ literatura sociológica, há referência a outros aspectos que poderiam explicar os comportamentos citados. Segundo Nichols (1975), a ocorrência de violações de regras de segurança, durante perturbações no processo de trabalho e tentativas de restauração da produção, está relacionada ao fato de que, para o trabalhador, permanecer no local de trabalho e não fazer nada, na vigência de uma perturbação na atividade realizada, “[...] significa permanecer do lado de fora do ritmo de produção: mas este ritmo é a única coisa que faz toleráveis muitas tarefas". Além disso, outro aspecto que contribuiria para essa intervenção do trabalhador seria o seu conhecimento de que, sem a correção da perturbação, adviriam aumentos nas cargas de trabalho dele e de seus colegas.

A literatura relativa aos comportamentos frente ao perigo e ao aprendizado organizacional pós-acidentes cita outros aspectos, também desconsiderados na abordagem mostrada nos materiais usados nas empresas estudadas. Estudiosos dessa corrente enfatizam a importância da exploração das razões que explicam a adoção das ações em questão, destacando a contribuição daquilo que, se a empresa tivesse feito, poderia ter evitado ou diminuído as chances de ocorrência do acidente (Dejoy 1985; Hale e Glendon 1987e; Hale e col. 1997). 
Uma das contribuições mais importantes de estudos realizados no campo da Ergonomia foi a identificação do papel da organização do trabalho na atividade real desenvolvida pelo trabalhador. Preconiza-se que essa organização seja suficientemente flexível, de modo a permitir ao trabalhador - ou grupos de trabalhadores - o controle de suas próprias ações. Ao mesmo tempo, denunciam-se aquelas organizações rígidas, de inspiração tayloriana, que impedem ou limitam as possibilidades de escolhas livres e autônomas por parte de cada trabalhador e/ou do desenvolvimento de estratégias coletivas de cooperação e de apoio que possibilitem a superação das dificuldades e reveses associados ao desenvolvimento da atividade. A abordagem do trabalho proposta nas frases de segurança usadas na empresa também se revela descolada dessa compreensão, mantendo-se alheia ao trabalho real.

O material recolhido junto às empresas de Botucatu concentra-se, seja no estímulo ao medo, seja na defesa de comportamentos de respeito a normas de segurança, seja no estímulo ao uso de EPI. De modo geral, adotam enfoque simplista e desconsideram a forma como vêm sendo discutidos, na literatura, os comportamentos humanos, nas situações de perigo. Como conseqüência, não é de estranhar a inexistência de avaliações do impacto dessas medidas, refletido, inclusive, no descumprimento de exigências legais firmadas pelo MTE.

$\mathrm{O}$ uso de frases de segurança e dos materiais citados em treinamentos de membros de CIPA parece relacionado ao mero cumprimento de uma formalidade implementada em empresas que dispõem de Serviço Especializado em Engenharia de Segurança e Medicina do Trabalho estruturado. Assim é que, independentemente de qualquer avaliação acerca de política, cultura e práticas de segurança existentes e realmente implementadas ou consolidadas nas empresas, atribui-se a ocorrência de acidentes ao desrespeito de regras, normas ou não uso de EPI.

\subsection{Investigações de acidentes: fator de viabilização de condições}

\section{perigosas?}

Em estudo em que discute a investigação de acidente, Lieber (1998) afirma que o propósito dessas ações é a viabilização de condições perigosas de trabalho, 
reforço da iniqüidade, exclusão de ações transformadoras e a defesa da disciplina. Em face de tais afirmativas, é lícito formular as seguintes interrogações:

a) É possível chegar-se à conclusão de tal amplitude com base em estudo que não se detém na abordagem da utilização prática de métodos de investigação nem de outras das atividades que fariam parte das características funcionais da gestão organizacional de riscos (Simard 1989)?

b) Ou que, em sua parte de campo, aborda apenas investigações baseadas em concepção dicotômica ou paucicausal de AT, tão distintas da maioria dos métodos surgidos a partir da década de 70 e que o autor critica indiscriminadamente?

c) Considerada a hipótese de que os resultados das IAT, em geral, fossem os apontados por Lieber, seria possível, com base em estudo com tais características, atribuí-los às teorias e métodos de investigação, desconsiderando-se toda a complexa rede de demais fatores capazes de contribuir para esses resultados?

A leitura apressada dos resultados das investigações de acidentes abordadas neste estudo pode sugerir respostas afirmativas às questões acima. No entanto, conforme mostrado ao longo das discussões desta tese, tais investigações caracterizam-se, claramente, como processos que visam ocultar a natureza de aspectos técnicos e sociais participantes da gênese dos acidentes. Paradoxalmente, tem-se, justamente em nome da investigação que deveria existir, o desenvolvimento de processo que tenta negar as suas possibilidades, através de mescla perversa de:

a) ações supostamente técnicas, como as abordagens centradas em concepção normativa de acidente com raízes plantadas nas idéias de Heinrich, na década de 30, aplicadas de forma reducionista;

b) ações voltadas para o atendimento de formalidades burocráticas e legais, como a obrigatoriedade da investigação de acidentes, nos moldes já comentados, a imposição de outras obrigações às empresas, como a 
constituição de Cipa, Sesmt, e a formação de integrantes desses organismos, desenvolvidas de acordo com as características anteriormente discutidas;

c) utilização de estratégias, práticas de ensino e materiais didáticos e pedagógicos voltados para a difusão da concepção normativa, às vezes, com "roupa nova", desconsiderando a evolução do conhecimento, em particular nas 3 últimas décadas, quando se desenvolve crítica veemente dessa concepção.

Ao condenar a investigação de acidente em si, Lieber assemelha-se à mãe que 'joga fora a criança junto com a água suja', sem conseguir desvendar a natureza intrínseca de construção social presente no ritual ("a investigação") a que assistiu. O pesquisador precisa estar atento à natureza desses processos, pois, ao condenar todas as práticas de investigação, inclusive aquelas dotadas de características cuja utilização não chegou a testar, age como quem espera que a mera existência do conhecimento seja suficiente para alavancar processo de mudança de relações sociais.

Simard (1989) destaca que, com freqüência, "pensa-se que a segurança é somente um conjunto de técnicas sem implicação com as relações sociais que estão no coração da produção dos riscos". Dwyer $(1991,1999)$ também aponta a necessidade de mudanças nas relações sociais como fundamento para a mudança das condições de segurança no trabalho.

Os achados deste estudo mostram a existência de contribuição das ações de técnicos (notadamente engenheiros e técnicos de segurança, mas também médicos do trabalho) contratados pelas empresas ou com atuação em organismos de apoio e/ou empresas de assessoria empresarial e de decisões institucionais no processo de ocultação da insegurança. Em outras palavras, este estudo mostra que as práticas de segurança adotadas nas empresas estudadas nem de longe assumem características semelhantes àquelas evidenciadas em serviços em que a gestão organizacional da segurança se mostrou eficaz. 
A gestão eficaz de riscos exigiria o desenvolvimento, no âmbito da empresa, de nova dinâmica social marcada por duas características: a) favorecer e legitimar a expressão da insegurança do trabalho vivenciada pelos [...] trabalhadores, representantes sindicais e chefias; b) outorgar, ao aparelho de segurança, o poder de regulação do aparelho de produção (Simard 1989).

Os resultados deste estudo mostram-se muito mais em conformidade com essa leitura do que com a opinião expressada por Lieber (1998). Isso significa que, ao lado da crítica aqui formulada às práticas de investigação adotadas nas empresas de Botucatu, no ano de 1997, compreende-se que sua existência revela uma das facetas assumidas pela fragilidade técnica e política da função segurança, nessas empresas, e não um exemplo de inocuidade de práticas de investigação de acidentes em si e independentemente da realidade de segurança.

Lieber nega qualquer tipo de contribuição de natureza transformadora em práticas de investigação de acidentes (p. 272). Ora, no Brasil e no mundo, multiplicam-se exemplos de mudanças na realidade de segurança e nos perfis de acidentalidade de empresas e regiões. Trata-se de processos que incluem múltiplos determinantes, como, por exemplo, escolhas tecnológicas, contextos sócio-políticos e culturais, reorganizações de processos produtivos e muitos outros, inclusive as atividades de prevenção desenvolvidas nas empresas e regiões. Em muitos casos, a existência de acidentes suscitou ações de sindicatos de trabalhadores ou intervenções de serviços públicos e universidades, envolvendo, entre outras medidas, a investigação desses eventos com diferentes técnicas cujos resultados têm sido apontados como contribuições ao processo de mudança.

Conforme discutido acima, pretender atribuir ou esperar de investigações de acidentes papel determinante na dinamização de transformações sociais representa exagero ou confusão em relação aos objetivos das mesmas, porém negar a existência de contribuições originadas de investigações constitui exercício de retórica reducionista e desconhecedor de grande número de exemplos descritos na literatura de segurança e saúde no trabalho (Faverge 1967; Hale e Hale 1972; Wigglesworth 1972, 1976; Méric e col. 1976; Leplat e Cuny 1979; Booth 1981; Haddon e Baker 1981; Saas e Cook 1981; Dwyer 1984, 1991, 1999; Simard 1989; Dwyer e Raftery 
1991; Wagenaar e Reason 1990; Monteau 1992; Kletz 1993; Raafat 1993; Doos e col. 1994; Hofmann e col. 1995; Ledeme 1995; Hale e col. 1997; Oliveira 1997). O fato de essa confusão associar-se a boas intenções do autor, infelizmente, não minimiza seu equívoco.

De modo semelhante a Méric e Szekely (1980), entende-se que análise de acidente pode e deve ser adotada como ferramenta auxiliar, integrada às demais práticas de gestão integral de risco. Para eles, trata-se de processo que inclui, além da análise de acidentes, a da estrutura e do funcionamento da empresa, abordagem psicossociológica (história da empresa, ambiente sócio-econômico, rede de comunicação, clima social da empresa, características sociológicas do pessoal, etc.) e detecção precoce de riscos do processo de trabalho e de postos de trabalho.

Embora Lieber se equivoque ao atribuir os problemas que constata em IAT às investigações em si, ele está correto ao identificar problemas nas investigações que estuda. O tema central deste estudo também é o da investigação de acidentes, em particular, a exploração das práticas adotadas em empresas possuidoras de CIPA, no município de Botucatu. Os achados descritos suscitam reflexão final acerca da contribuição que pode advir das IATs para o conhecimento das situações de trabalho e como subsídio para a mudanças dessas situações.

\subsection{As práticas de prevenção de acidentes do trabalho, em empresas de Botucatu}

Discutindo as práticas da Engenharia de Segurança, Lima e Assunção (2000) afirmam que o apego a normas e à prescrição de atos seguros ensejaram deturpação da prática prevencionista:

"Há uma série de procedimentos, todos criados com as melhores das intenções, que se tornam meros rituais uma vez que são incorporados à legislação e tornados obrigatórios na prática da engenharia de segurança e de outras profissões relacionadas à saúde do trabalhador. [...]

Ser engenheiro de segurança corresponde cada vez mais a saber de cor a pequena "bíblia verde”, o livro que agrega as portarias e normas regulamentadoras. A discussão em torno de alterações das normas mobiliza mais tempo e esforço do que qualquer outra ação em prol da segurança. 
Nesse mesmo estudo, Lima e Assunção (2000, p. 5) ressaltam a participação em acidentes de "condições consideradas "normais", como troca de turnos, introdução de novas tecnologias, substituição de mão-de-obra (sobretudo dos experientes), programas de aumento de produtividade, terceirização". Os autores destacam a perplexidade vivida pelos profissionais de segurança, quando deparam com esses tipos de circunstâncias. Além disso, defendem seu reconhecimento como situações potencialmente perigosas, em face de sua capacidade de desestabilização dos mecanismos reguladores adotados pelos operadores para a manutenção do controle do sistema.

Os autores respondem que, nessas situações, é freqüente se retroceder à idéia de fatalidade, considerando-se o acidente "sem causa (sem culpa)". Como consequiência, nada se faz em termos de prevenção; quando muito, recomenda-se cuidado.

Num estudo recente, Llory criticou a idéia de que "a normatização do trabalho resolve todos os problemas, todas as dificuldades de trabalho". Para ele, os procedimentos, as prescrições, embora necessários, não seriam suficientes, pois

"[...] Não é possível durante a elaboração de um procedimento levar em conta todas as combinações complexas de eventualidades, de acontecimentos, de possíveis cenários”.

No caso das empresas estudadas em Botucatu, verifica-se que, apesar de solicitação expressa nesse sentido, apenas 3 empresas apresentaram material que corresponde a procedimentos ("passo a passo") ou normas de segurança a serem seguidos em algumas atividades. Além disso, apenas 01 empresa apresenta registros relativos a políticas e práticas de segurança, e poucas são as empresas que mostram possuir esboços de documentação formal para uso no campo da segurança do trabalho. Esses fatos permitem suspeitar que, nessas empresas, as regras e normas que estão sendo desrespeitadas por ocasião dos acidentes não estão registradas e não são tema de nenhum tipo de iniciativa desenvolvida de modo estruturado, sistematizado e/ou contínuo, com vistas a seu enraizamento entre os trabalhadores.

O treinamento de membros das CIPAs constitui-se na única ação, repetida ano a ano em praticamente todas as empresas, a abordar a temática da investigação 
de acidente. Além disso, de modo esporádico, há uso de cartazes e/ou frases de segurança. Em face dessa constatação, pode-se afirmar que, neste estudo, as práticas de segurança assumem características de ritual voltado ao cumprimento formal de exigências legais. Atribuir os acidentes ao descumprimento de normas ou regras inexistentes e cuja existência não é alvo de nenhuma iniciativa efetivamente interessada na sua incorporação às práticas desenvolvidas nas empresas representa ação política que objetiva, simplesmente, culpar os acidentados pelos acidentes de que são vítimas.

Não se deve perder de vista que isso ocorre em momento em que a evolução do conhecimento demostra a insuficiência de abordagens normativas de prevenção de acidentes, destacando a importância que os "savoir-faire", conhecimentos tácitos, inteligência astuciosa, saber prático, regras informais e competências relativas à vida social e ao trabalho coletivo no meio de trabalho assumem para a própria segurança no trabalho.

Dejours (1993b) - que estuda esses conhecimentos em empresas caracterizadas por baixa frequiência de acidentes de proporções catastróficas, ou seja, empresas que, em geral, conseguiram patamares aceitáveis de confiabilidade e segurança de seus componentes técnicos e passaram a dedicar maior atenção à confiabilidade de seus componentes humanos - afirma que esses conhecimentos são ainda mais importantes, quando os indivíduos trabalham em indústrias de risco. Isso nos permite formular pelo menos um questionamento: será que, em empresas caracterizadas por frequiência de acidentes elevada e patamares de confiabilidade e segurança de seus componentes técnicos ainda insuficientes, esses conhecimentos estão presentes da mesma maneira? assumem aspectos particulares? têm a mesma importância para a segurança? ou a ocorrência de acidentes é indício de sua insuficiência face à natureza e característica dos riscos presentes, suscitando mudanças nesses mecanismos? Sendo afirmativa a resposta a esta última questão, qual é, nessas condições, o papel desse conhecimento não formalizado dos trabalhadores ou grupos de trabalhadores aí expostos?

Este estudo não procurou responder a esses tipos de questões, que ficam sugeridas como tema para novos estudos. No entanto, os achados que as suscitam 
ajudam na descrição de aspectos do que, na figura 7 , denomina-se receita de construção de culpa dos acidentados. Nessas situações, a ordem de entrada dos ingredientes não altera o resultado esperado.

De acordo com essa figura, assume papel central, na construção da culpa, a concepção normativa segundo a qual os ATs acontecem "porque se ignoraram determinadas regras e normas que os preveniriam ou porque não se analisou (ou analisou de forma deficiente) o meio ambiente”. O uso das categorias ato inseguro e condição insegura, por vezes com novas denominações, mas com as mesmas definições, aparece como elemento de auxílio, nesse processo, de modo secundário e decrescente em relação ao observado em algumas empresas do município, em estudo anterior (Binder e col. 1997). O desprezo por contribuições presentes na literatura relativa às investigações de acidentes e à sua prevenção surge como outro ingrediente desse processo. Apegar-se a técnicas ultrapassadas, evitando discussões acerca de critérios de escolha de estratégias e/ou medidas de prevenção e/ou dos resultados obtidos com as mesmas, facilita a difusão de concepção simplista e reducionista desses fenômenos.

As propostas de "prevenção" baseadas exclusivamente em sugestões de mudanças de comportamento dos acidentados ou de seus colegas, em situações de trabalho, caracterizadas por risco evidente, acrescentam verdadeiro toque de requinte de crueldade a esse cenário. Mais grave: sem a menor desfaçatez, essas recomendações revestem-se de roupagem técnico-científica, sacramentada, na maioria das vezes, pela autoridade de engenheiros e técnicos de segurança ou de médicos do trabalho.

A difusão dessa concepção restrita de causas de acidentes revela-se favorecida por grande número de publicações patrocinadas por organismos oficiais e patronais, assim como pelo estabelecimento da obrigatoriedade de investigação de acidentes e de criação de serviços de segurança do trabalho em empresas, fatos que contribuem para ampliação de mercado de trabalho para, pelo menos, 2 tipos de profissionais: engenheiros e técnicos de segurança do trabalho, cuja formação, no tocante à prevenção dos acidentes de trabalho, pauta-se pelos conceitos de atos 


\section{Figura 7. Receita de atribuição de culpa}

Inicie com a crença de que os acidentes decorrem do desrespeito a (ou inexistência de) regras, normas, prescrições ou que são devidos à não-utilização de EPI.

Refogue junto com as idéias de que até $90 \%$ dos acidentes associam-se a "atos inseguros", "atos abaixo do padrão" ou "falhas humanas", definidos de modo genérico e subjetivo.

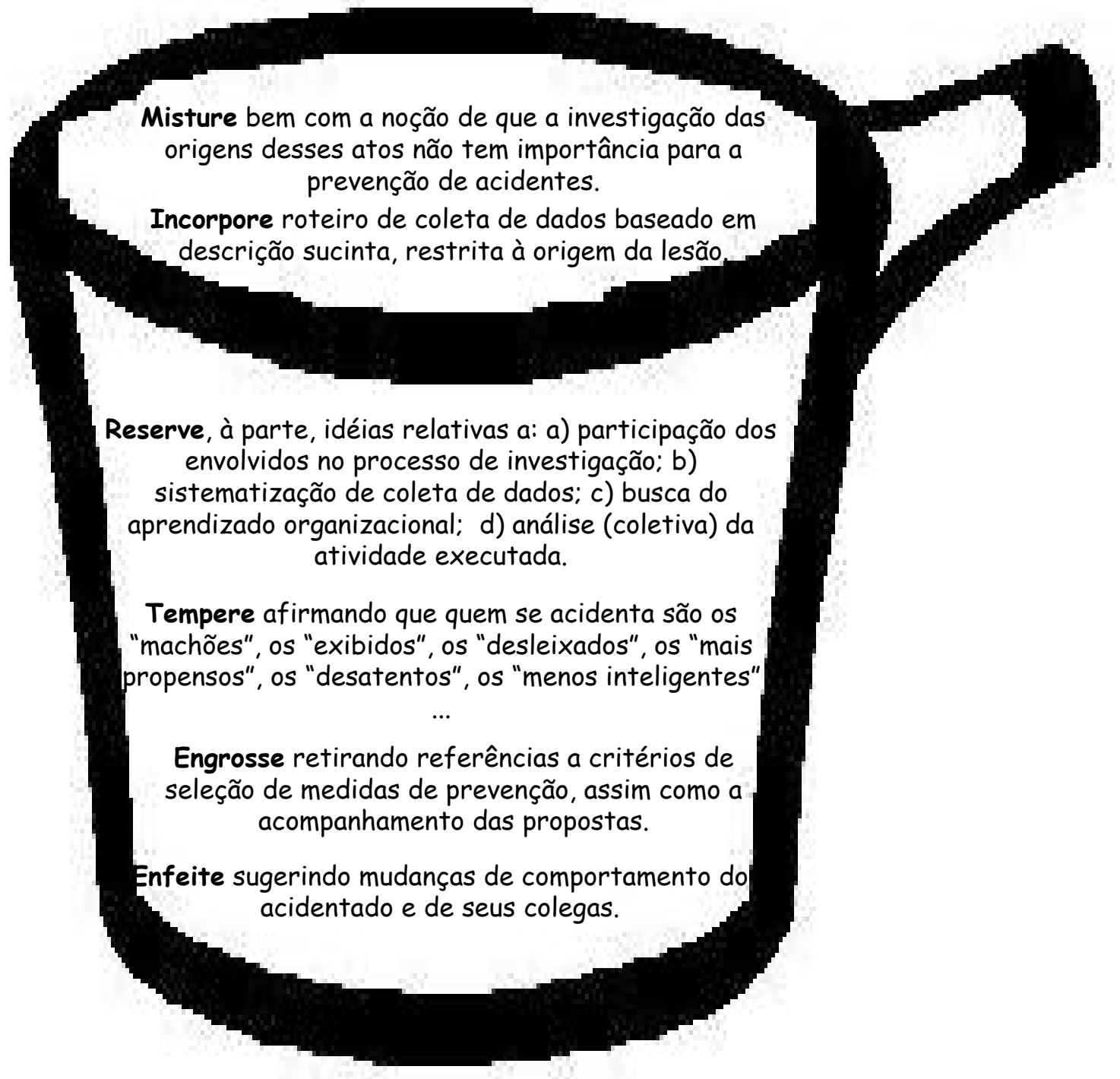

Divulgue com cartazes, frases, apostilas, filmes, etc., que apresentem as idéias acima como científicas, estimulem o medo de acidentes, o viés de otimismo, obediência às normas, regras, prescrições e o uso de EPIs como solução para todos os problemas. 
inseguros e de condições inseguras/condições ambientes de insegurança, desenvolvidos por Heinrich.

\subsection{Para onde vai a investigação de acidentes do trabalho?}

$\mathrm{Na}$ introdução desta tese, mostra-se trajetória de concepções de acidentes do trabalho, de proposições de investigações desses eventos e suas repercussões nas recomendações referentes à prevenção de acidentes.

Enfatiza-se o fato de a trajetória descrita ocorrer em sincronia com evolução das realidades de segurança estudadas, ou seja, ao mesmo tempo que se resolvem problemas de segurança mais comuns, melhoram as taxas de freqüência de acidentes, constata-se a necessidade de aprimoramento ou refinamento de técnicas de análise e inicia-se a utilização de instrumentos capazes de detectar fatores de acidentes não evidenciados com as práticas prevalentes até então.

Na trajetória de técnicas de investigação, destacam-se características que as diferenciam, enfatizando-se: a) a necessidade de conhecimento da situação sem acidente, habitual ou cotidiana de trabalho abordada como sistema sócio-técnico aberto; b) a reconstrução do acidente com o uso de categorias de análise que descrevem os componentes do sistema em que ocorre o AT, com a formulação de questões abertas e com posterior validação coletiva das informações coletadas; c) a exploração das inter-relações entre fatores, buscando identificar as diferentes formas que assumem e as razões da história de cada empresa associadas a cada processo.

O método de árvore de causas, além de ser um dos que possuem essas características, alcançou certa difusão no País, sendo utilizado, inicialmente, em filiais de empresas de origem francesa e, atualmente, também por outras que se revelaram interessadas e em serviços públicos de saúde do trabalhador. Essa técnica é difundida por entidades sindicais de trabalhadores; recomendada em publicação patrocinada pela Organização Internacional do Trabalho (OIT), tendo chegado a ser incluída em projeto de norma regulamentadora do MTE, que determinava sua utilização obrigatória por membros de CIPA, em empresas. 
Comentando as diferentes fases da intervenção ou exploração de árvores com esse método, De Keyser (1979) registra a existência de aspectos implícitos na sua utilização. Segundo a autora, o diálogo e as negociações necessários à aplicação da técnica, em todas as suas etapas, da coleta de dados ao acompanhamento da implantação de medidas de prevenção, agem sobre fatores de risco que não aparecem nas árvores, como as atitudes em relação à segurança e fatores psicológicos sobre os quais é impossível uma ação direta. Esse tipo de observação, em geral, só é possível a pesquisadores com vivência da aplicação da técnica, ou seja, que a dominem efetivamente.

Discutindo as condições necessárias à implantação do método, Monteau (in Chich 1984), afirma:

“[...] não se trata somente de introduzir uma modificação de procedimentos (de investigação) mas também de fazer evoluir as atitudes, de mudar os comportamentos e, finalmente, de introduzir uma mudança para que entre o "antes" e o "depois" a gestão da segurança seja diferente.”.

A referência ao método, na introdução deste estudo, surge como exemplo da trajetória das investigações. A discussão posterior dá-se em função de sua utilização em quatro das empresas do município.

A trajetória mostrada na introdução desta tese mostra que, por ocasião do surgimento do método $\mathrm{ADC}$, a distinção entre trabalho real e trabalho prescrito começava a ser esboçada, sendo que Faverge (1967) já difundira as noções de perturbação e de recuperação da tarefa e, com elas, a possibilidade do surgimento de situação em que a recuperação tentada não alcançava êxito, possibilitando a instalação de degradação da tarefa que culminasse em acidente e/ou outras perdas para o sistema.

Atualmente, não faz sentido pensar a utilização do método ADC sem redefinir a noção de trabalho habitual à luz das contribuições da corrente francesa da Ergonomia, como a noção de atividade e de sua variabilidade normal e incidental, a demonstração da importância dos objetivos determinados pelos gestores e definidos pelos operadores, as estratégias de regulação individuais e coletivas, como o 
planejamento e a antecipação de eventos, enfim, noções como as de gesto e compromisso cognitivo, comentadas na introdução deste estudo.

Além disso, muda a própria noção de equilíbrio dinâmico, originalmente adotada na teoria de sistemas. Firma-se compreensão de equilíbrio dinâmico em evolução, ou seja, que incorpora compreensão de que o(s) operador(es) está(estão) colocado(s) em processo de adaptação e transformação constante, mediado pela experiência adquirida, pelas reflexões desenvolvidas na e sobre a atividade. Como consequiência, mudam também as estratégias de intervenção desenvolvidas pelo(s) operador(es), os resultados de sua atividade e a própria atividade. $\mathrm{O}$ estímulo à reflexão dos operadores sobre seus saberes acerca de suas competências, à confrontação de seus pontos de vista, visando ao desenvolvimento de universos de referência mais subjetivos e à tomada de consciência, é defendido como motor da mudança de ponto de vista para a obtenção de ação de mudança (Teiger 1993).

Isso significa, entre outras coisas, que o uso da noção de variação se refere, sobretudo, à comparação do resultado do desempenho, nas situações sem e com acidente, e deixa de lidar com importantes aspectos subjetivos do acidente, associados às origens dos gestos adotados na atividade e para fazer face à sua variabilidade. Trata-se, principalmente, de processos cognitivos, aspectos subjetivos, intrapsíquicos, adotados por um trabalhador ou grupo de trabalhadores presentes no acidente, e que não são identificados como tal com a mera descrição de ações ou comportamentos.

Ao desenvolver as habilidades e capacidades de usar esses mecanismos na regulação dos eventos, o trabalhador adquire sua competência, desenvolve sua capacidade de fazer face a dificuldades novas, num processo que exige o reconhecimento da utilidade do produto de seu trabalho, por parte das chefias, mas também o reconhecimento de seus companheiros acerca da beleza desse produto (Dejours 1997). Tais reconhecimentos associam-se à formação da identidade do indivíduo e da noção de pertencente a um grupo, favorecendo o estabelecimento de relações de cooperação e solidariedade, que, quando não existem, comprometem a confiabilidade e a segurança do sistema. Por sua vez, o estabelecimento dessas relações exige, entre outras coisas, que o trabalho se desenvolva em clima de 
confiança, possível quando as práticas de gestão da segurança são participativas (Dejours 1993a, b, 1997).

A análise com o método ADC deixa de lado vários desses aspectos, embora possa identificar fatores ligados a alguns de seus antecedentes e suscitar a formulação de demanda acerca de estudo complementar. Tradicionalmente, o método inclui estudo de aspectos das ações humanas relacionados a:

a) características do indivíduo (I)- notadamente seus aspectos físicos, fisiológicos, psicológicos, adesão ao uso de EPI, de experiência e formação profissionais;

b) exigências da tarefa $(\mathrm{T})$ - movimentos e posturas adotados nas ações cortar, apertar, transportar, deslocar-se, operar, alinhar, etc. - da seqüência de operações da tarefa;

c) exigências originadas em materiais (M) - matérias-primas, fontes de energia, ferramentas;

d) exigências associadas ao meio de trabalho (MT) físico e gerencial interferências da iluminação, de temperaturas extremas, decisões ligadas à gestão de pessoal, de tempos de produção, de procedimentos e normas de produção e de manutenção, de fornecimento de materiais (atrasos, qualidade), de metas de produção, da provisão de meios, de escolha ou determinação dos meios a serem usados, das relações pessoais com chefias e colegas, interferências de componentes de outras atividades, formas de coordenação entre atividades, de adesão à legislação de segurança, etc.

A análise assim conduzida mostra-se mais fácil quando busca elucidar aspectos ligados diretamente aos componentes técnicos do sistema. A análise do jeito que o trabalhador faz para fazer seu trabalho pode esclarecer suas relações com aspectos dos componentes I, T, M e MT, como os acima descritos. Tomando-se o exemplo de fatores da gestão e organização do trabalho, do componente MT, verifica-se que a contribuição da análise está centrada, tanto na identificação da 
existência ou não dessas práticas, como na das formas assumidas por aspectos dessas práticas, nos casos em que sua participação, num acidente, é identificada. Essa segunda possibilidade diferencia esse método de outros, como, por exemplo, o MORT, que permite identificar a existência de falha em práticas gerenciais com questões de tipo sim ou não.

A análise assim conduzida não se aprofunda no esclarecimento de estratégias cognitivas adotadas pelos trabalhadores, quando estes se defrontam com a variabilidade da atividade, seja esta normal ou incidental. Isso significa que, na análise de acidentes de tipo 2 ou 3, em que esses mecanismos tenham participação, embora seja até possível a identificação de fator(es) da gestão e da organização do trabalho associado(s) à origem de seu impacto no fracasso do desempenho do trabalhador, não se consegue evidenciá-los.

A análise ADC mostra-se mais limitada na abordagem de acidentes em que as origens do fracasso dos mecanismos de regulação adotados estejam em fatores ou características do indivíduo. O mesmo acontece quando os mecanismos de regulação envolvem coletivos de trabalhadores.

Neste estudo, mostra-se que essa forma de abordagem das ações dos trabalhadores não está sendo adotada nas práticas de investigação de empresas do município de Botucatu, possuidoras de CIPA. Nelas, adota-se procedimento de análise centrado na comparação de comportamentos com os ditames de normas e prescrições, resultando em conclusões do tipo "desrespeito à norma", desconsiderando que, nas condições em que o sistema opera, sua segurança e sua confiabilidade decorrem, justamente, daquelas estratégias e que estas fazem parte do repertório habitualmente adotado pelos operadores, ou, pior ainda, a utilização dessas estratégias pelos trabalhadores sequer é identificada pelas empresas.

O desenvolvimento da noção de erro humano e de sua classificação levou alguns autores à defesa da idéia de que, com a melhoria da confiabilidade e da segurança dos componentes técnicos dos sistemas, a ocorrência de acidentes estaria ligada, essencialmente, aos erros cometidos pelo(s) operador(es). A investigação dos acidentes deveria passar a basear-se na análise desses erros: 
“[...] porque, na origem de um acidente nos lugares de trabalho, que são lugares artificiais construídos e organizados pelo homem, há sempre um erro humano ou uma conjunção desse erro com uma situação acidental, que resulta, ela mesma, de outro erro humano" (Goguelin 1996).

Segundo Goguelin, ao recusar-se a examinar o erro humano, a análise ADC desresponsabiliza os homens que cometem esses erros. Essas investigações procurariam negar a culpa (“déculpabiliser") ou desculpá-la, atribuindo a falta ao sistema, à empresa e a seu chefe. Após tecer comentários extremamente críticos em relação a esse método, Goguelin (1996) afirma “[...] não é necessário todavia rejeitar esse tipo de método dos quais o mais conhecido é o de árvore de causas [...]" (p. 58) e "Todavia, nós sublinhamos novamente que a árvore de causas e o método cognitivo devem ser complementares e controlar-se um ao outro" (p. 64). A complementaridade dessas duas abordagens também foi defendida por Leplat (1982, 1985) e Leplat e Rassmussen (1987), que publicaram estudo de caso associando-as.

A trajetória das concepções de acidente e de sua investigação mostra que a melhoria da segurança se acompanha de aumento das dificuldades do processo de análise de acidentes. Burgoyne (1993) defende a necessidade de investigações formuladas com características de projetos de pesquisa. Por sua vez, Llory (1996) propugna a realização de estudos clínicos minuciosos acerca dos acidentes. Llory defende, de modo especial, a realização de descrição subjetiva do acidente que incorpore a percepção e o julgamento de gerentes/chefias intermediárias e dos próprios operadores.

Paradoxalmente, este estudo mostra que as práticas de investigação rotineiras, desenvolvidas em empresas, estão assentadas sobre bases teóricas descoladas da evolução do conhecimento e da noção de conhecer para transformar. Centra-se o "olhar" sobre as ações dos trabalhadores e na identificação de suas distâncias em relação a normas, prescrições e comportamentos de suposto representante da "média" da população. Eventualmente, associa-se a checagem de dispositivos de segurança, especialmente daqueles previstos em lei.

Em face dessa realidade, entende-se que a investigação de rotina desenvolvida nas empresas exige mudanças. Na visão do autor desta tese, constitui 
equívoco a idéia de que possa existir um método ou técnica de investigação ideal cuja utilização deva ser recomendada para todo e qualquer tipo de acidente, para toda e qualquer realidade de segurança. A posição aqui defendida é a de que a escolha das técnicas a serem usadas associem coerência com a realidade de segurança, com o estágio de evolução dos conhecimentos sobre os processos usados na investigação e no sistema em que ocorre o acidente e com as condições de praticidade necessárias a instrumentos de uso rotineiro.

As técnicas de investigação de acidentes que associam as características citadas $^{12}$ possuem maior potencial de contribuição analítica. Além disso, considerase que, embora a classificação de erros humanos baseada em mecanismos cognitivos adotados pelo operador, por ocasião do fracasso de seu desempenho, possa trazer contribuições à formulação e escolha de estratégias de prevenção, as noções de dinâmica de representação e gestão das ações (Weill-Fassina 1993) e de compromisso cognitivo (Amalberti 1996) parecem mais apropriadas à exploração dos mecanismos de regulação adotados pelos trabalhadores para fazer o que tem que ser feito.

Como conseguir que empresas, como as abordadas neste estudo, incorporem, em suas práticas de investigação, abordagem da atividade real dos operadores? Estarão os atores atualmente envolvidos nas atividades de saúde e segurança das empresas e instituições afins preparados para dar vida e impulsionar movimento social com objetivo desse porte?

Os relatos deste estudo acerca das diferenças encontradas nas formas de implantação ou introdução do método ADC indicam que as condições ou contextos a serem enfrentados em processo dessa natureza são extremamente heterogêneos. De qualquer maneira, parece importante o desenvolvimento de experiências piloto, de tentativas de mudanças que possam servir de exemplo e incentivar a construção de novas práticas de investigação de acidentes.

\footnotetext{
12 a) Conhecimento da situação sem acidente ou habitual abordada como sistema sócio-técnico aberto; b) Categorias de análise, reconstrução do acidente com a formulação de questões abertas e validação coletiva; c) exploração das inter-relações entre fatores.
} 
Os resultados da recente revisão da Norma Brasileira sobre acidentes do trabalho, discutidos por Baumecker (2000), indicam que não. A Portaria DSST MTE, número 8, de 23 de fevereiro de 1999, que altera a NR 5, indica que sim. Essa Portaria, que dispõe sobre a Comissão Interna de Prevenção de Acidentes, extingue o antigo anexo II, que inclui formulário de investigação de acidentes a ser preenchido e discutido pelos membros da comissão, e deixa de impor modelo de formulário de investigação. A partir dessa publicação, o treinamento dos integrantes da CIPA exige “metodologia de investigação e de análise de acidentes e de doenças do trabalho". Além disso, em comentário a esse item da norma, publicação oficial do Ministério (BRASIL 1999) recomenda:

“É importante que o método escolhido seja participativo e que se proponha buscar causas intervenientes, com o objetivo de eliminá-las ou de inserir barreiras protetoras, e não com o objetivo de classificar de forma simplória o acidente, que é sempre complexo, e muito menos, de buscar configurar culpados [...]

Estudo dos casos clássicos de acidentes que tenham ocorrido na empresa ou em similares. $O$ estudo de possibilidades de acidentes também se faz promissor” (p. 29).

A mudança ocorrida no texto legal retira aspectos negativos vigentes até então e introduz fórmula aberta capaz de permitir ou facilitar a adoção de melhorias adicionais amparadas na evolução dos conhecimentos e mudanças sócio-políticas presentes em realidades locais. No entanto, é importante ressaltar que seu surgimento ocorre descolado de movimentos sócio-político-culturais centrados em questionamentos ou denúncias da inadequação do modelo de abordagem de acidentes vigente no País. Existem, é verdade, denúncias e clamores por mudanças ainda localizados em setores universitários, parcela expressiva de técnicos de nível superior que atuam em órgãos públicos e representações sindicais de trabalhadores.

Por isso mesmo, as possibilidades de melhorias que podem advir de mudanças na legislação de saúde e segurança parecem ainda tímidas e com pequeno poder de fogo face ao enraizamento e difusão das velhas práticas. Os desdobramentos desse processo tendem, portanto, a depender dos caminhos traçados pela convivência dessas diferentes concepções. E, embora de alcance limitado, as contribuições de técnicos que atuam nesse campo parecem despontar, no momento, 
como de grande importância na definição dos rumos a serem adotados pelas práticas de investigação de acidentes no País.

Estratégias já ensaiadas entre nós, como a da obrigatoriedade do uso de técnicas de investigação consideradas de maior potencial de contribuição analítica, não parecem o melhor caminho para esse processo. Afinal, em contexto como o brasileiro, marcado por predomínio de concepção simplista do fenômeno acidente, por difusão prévia inadequada dessas técnicas, por dificuldades que lhe são intrínsecas e por práticas de investigação superficiais, podem constituir incentivo à sua deturpação, inviabilizando seu uso.

Neste estudo, denuncia-se que as práticas de investigação de acidentes desenvolvidas nas empresas estudadas se dão à margem da trajetória dos conhecimentos acerca dessas análises e que esse divórcio pode ser apontado como um dos ingredientes que auxiliam a elaboração das práticas de atribuição de culpa. Aponta-se, também, que o aumento do perímetro da investigação implica na identificação de fatores cuja correção exige intervenção mais difícil que aquela baseada na aplicação de normas legais.

Embora concordando com essas idéias, questiona-se se a ampliação do perímetro das investigações, proposta por Burgoyne (1993) e por Llory (1996), deve ser estendida a todas as investigações de acidentes conduzidas em todas as empresas, inclusive, aquelas onde predominam acidentes de tipo 1.

Considerando que, nos acidentes de tipo 1, as condições de componentes técnicos do sistema, em geral, participam de modo importante na degradação da sua segurança e que sua identificação e correção podem beneficiar-se, significativamente, de procedimentos de inspeção de segurança, inclusive aquele baseado em questionários, entende-se que a ampliação do perímetro das investigações para realidades de segurança em que predominam acidentes desse tipo só deva ocorrer em situações especiais, selecionadas pós estudo preliminar de série de acidentes e sem a formulação de correções efetivas. 
Desse modo, não se discorda da afirmação de Baumecker (2000) de que investigações sistemáticas desses tipos de acidentes podem evidenciar falhas sistêmicas não vistas em abordagens por questionários, porém se destaca que o uso destes instrumentos permite, de modo ágil e de fácil utilização com recursos disponíveis em qualquer sistema, identificar situações inaceitáveis do ponto de vista da segurança, que são de solução também simples e já amplamente conhecida.

Afinal, conhecer a realidade em que se pretende atuar, definir objetivos e escolher ferramentas adequadas às suas características é ponto de partida que não deve ser esquecido pelos interessados em qualquer tipo de mudança.

As concepções adotadas na legislação brasileira de acidentes e na Norma Brasileira (NB), editada sob os auspícios da ABNT, organismo de assessoria empresarial, foram citadas na introdução desta tese para ilustrar sua dessincronia ou seu divórcio com aquelas mostradas na trajetória dos conhecimentos. Mostra-se, ainda, que, nas investigações desenvolvidas no âmbito de empresas, há forte influência da concepção dicotômica e paucicausal presente na legislação e na NB e que a abordagem das origens das ações dos trabalhadores com freqüência envereda pelo caminho do preconceito, sendo concluída de modo que atribui culpa à vítima do acidente.

Na casuística estudada, não há acidentes do tipo que Perrow denominou de normal ou sistêmico. A descrição dos acidentes deste estudo e também a de acidentes industriais considerados graves, no mesmo município (Almeida 1996), mostram que a maioria dos fatores de acidentes identificados, mesmo aqueles de natureza organizacional, não considerados como de risco na legislação brasileira, correspondem a fatores já descritos na literatura como potencialmente acidentogênicos. Ou seja, se as consequiências, para a saúde e segurança, de sua escolha e adoção fossem previamente analisadas, o risco de acidente seria identificado com relativa facilidade.

O processo descrito mostra que a abordagem proposta possui dificuldades técnicas que não devem ser minimizadas e que exigem domínio, seja de técnicas de investigação, seja de ferramentas de análise ergonômica e psicossocial. No entanto, 
destaca-se que a sua adoção implica na necessidade de condições que vão além da "mera" capacitação dos responsáveis pela condução ou animação do processo de análise - que inclui etapas de implantação e acompanhamento de estratégias e medidas de prevenção -, dizendo respeito à mudança de concepção acerca dos acidentes e sua investigação, não só por parte dos técnicos ou pessoal que as realiza, mas de toda a empresa, particularmente de seus gerentes e chefias intermediárias, que podem ter suas decisões e escolhas questionadas na análise.

A análise dotada das características citadas caminha para o questionamento das "lógicas" e dos interesses considerados no processo de organização e gestão da produção na empresa. No limite, questiona se a prevenção de acidentes ou saúde dos trabalhadores foi pensada e quem decide os interesses que serão considerados. $\mathrm{Na}$ maioria das empresas, o processo de organização e gestão adotado é regido, exclusivamente, pela racionalidade econômica com a adoção de estratégias de redução de custos que desconsideram ou não levam em consideração questionamentos acerca de possíveis impactos na saúde dos trabalhadores.

Dada a natureza "mutante" das empresas, a prevenção ideal deve associar-se à própria ocorrência das mudanças, constituindo-se em parte de processo permanente de vigilância e antecipação de riscos. Isso significa que, idealmente, a avaliação de possíveis impactos deve ocorrer todas as vezes que a empresa é colocada diante da possibilidade de passar por mudança de meios, de processo, de contexto econômico, do perfil de seu pessoal, por exemplo, com a contratação de não qualificados ou de serviços de empreiteiras, etc. Se a empresa perde a oportunidade de desenvolver essa nova política, pode vir a defrontar-se com dificuldades maiores, na tentativa de remendos posteriores ao aparecimento de acidentes e outras perdas indesejáveis para o sistema.

Para finalizar, um último comentário acerca do destaque dado nesta tese à questão do respeito às características intrínsecas da técnica escolhida e dos cuidados necessários na sua utilização. Seu surgimento associa-se a alguns dos fatores semelhantes aos que levaram Baumecker (2000) a referir-se à existência de risco corrido por propostas inovadoras em realidades social e politicamente atrasadas como a brasileira. Entre eles, vale a pena mencionar: a) trata-se de questão já 
apontada em estudos que discutem experiências de implantação do método e que se revela verdadeira, nas empresas estudadas, onde o uso do método ADC é alvo de distorções grosseiras; b) no Brasil, mas também em outros países, o surgimento de referências a técnicas novas ou pouco difundidas tem ensejado a proliferação de ações oportunistas que assumem a forma de assessorias, oferta de produtos e, no caso do método ADC, de cursos de curta duração com formato caça-níqueis; c) a reação a esse tipo de iniciativa pode ser alvo de ação desenvolvida com os recursos hoje acessíveis em instituições públicas e de ensino.

Baudelaire (apud Konder 1988, p. 22) lembra com propriedade que "Só se destrói, realmente, aquilo que se substitui”. Os achados e as reflexões desenvolvidos na elaboração deste estudo indicam que a substituição da concepção de acidentes vigente entre nós exige mais do que os necessários esforços de aprimoramento da formação técnica dos profissionais envolvidos. É verdade que essa concepção não basta para a construção da mudança pretendida. Por isso, retomando o paralelo com a culinária, esboçado no início desta tese, sugere-se considerar os seguintes princípios e ações como ingredientes e passos para a confecção desse "prato"13, que se pretende com sabor especial de mudança:

a) Adotar como fonte de calor desse prato a vontade de mudança, assumida como objetivo de práticas de formação e de investigação de acidentes.

b) Iniciar incorporando nas análises o estudo das situações habituais de trabalho e a valorização da compreensão de sua variabilidade normal e incidental e de sua constante evolução.

c) Engrossar acrescentando proposição de categorias que facilitem sistematização da coleta de dados. Assegurar-se de que esta ocorra de forma aberta, explorando as interações entre fatores até o limite do conhecimento disponível.

d) Sempre que necessário, adicionar, precocemente, tempero picante com abertura de espaço para a discussão e valorização da controvérsia. Deve-

\footnotetext{
${ }^{13}$ Parte dos aspectos citados baseiam-se em Lima e Assunção (2000).
} 
se buscar o resgate da "intuição e da experiência dos trabalhadores, sobretudo daqueles que estão em posição subalterna e que não dominam nem as habilidades discursivas nem os instrumentos de demonstração matemática e experimental de suas opiniões".

e) Juntar compreensão dessa construção como processo coletivo a ser desenvolvido de modo contínuo.

f) Cozinhar, por partes, considerando tratar-se de ingredientes com tempo de cozimento diferente a serem reservados e, só depois, associados, respeitando a noção de processo e prolongando o prazer dos que participam de seu preparo e do processo de sua degustação.

g) Durante todo esse processo, reservar, bem à parte, concepções baseadas na dicotomia ato inseguro/condições ambiente de segurança, práticas de abandono precoce de busca das "causas das causas" e de conclusão das investigações com recomendação de mais atenção ao perigo por parte da vítima.

h) Experimentar o sabor com freqüência, procurando evitar o predomínio oriundo dos componentes relativos a processos técnicos, como interações de componentes que explicam ocorrência de explosão, incêndio, quebra, etc. Se isso ocorrer, corrigir o sabor, desenvolvendo a busca até a identificação das decisões e demais aspectos que explicam a origem daquela distorção.

i) Como acompanhamento principal, incentivar contribuições em iniciativas institucionais voltadas para o aprimoramento da intervenção do estado e de organizações sociais, no campo da saúde e segurança do trabalho, buscando, sobretudo, ampliar o leque de atores sociais chamados à participação e trazer para o debate contribuições que explicitem o estágio atual de evolução do conhecimento. 


\section{REFERÊNCIAS BIBLIOGRÁFICAS}

1. Allegrante JP, Sloan RP. Ethical Dilemmas in Workplace Health Promotion. Preventive Medicine 1986; 15: 313-20.

2. Almeida IM. Desvendando a zona de sombras dos acidentes do trabalho. São Paulo, 1996. [Dissertação de Mestrado, Faculdade de Saúde Pública da USP].

3. Almeida IM, Binder MCP. Reflexões sobre o uso do método de árvore de causas pelo movimento sindical. Saúde em Debate 1996; (49/50): 65-72.

4. Almeida IM, Binder MCP, Fischer FM. Blaming the Victim: Aspects of the Brazilian Case. International Journal of Health Services 2000; 30: 71-85.

5. Amalberti R. La conduite des sistèmes à risques. Paris: Presses Universitaires de France; 1996. La sécurité des grands systèmes techniques: l'erreur humaine comme dernière frontière; p. 25-44. (PUF - Collection Le Travail Humain).

6. Assistance Publique / Hopitaux de Paris. L'Arbre des causes. Guide Methodologique. Paris: Assistance Publique / Hopitaux de Paris; 1988.

7. Associação Brasileira de Normas Técnicas. Cadastro de acidentes. Norma Brasileira 18. São Paulo: ABTN; 1975.

8. Azevedo ND. Caracterização de situação de risco grave e iminente. Brasília: Ministério do Trabalho e Emprego / Secretaria de Inspeção do Trabalho / Departamento de Segurança e Saúde no Trabalho - Fundacentro; 2000. [Apostila de curso "Combate aos acidentes fatais decorrentes do trabalho", p. 9-34].

9. Barreiros D. A segurança e a organização do trabalho em uma mineração subterrânea de carvão da região de Criciúma - Santa Catarina. São Paulo, 1996. [Dissertação de Mestrado - Escola Politécnica da Universidade de São Paulo]. 
10. Baker SP, Samkoff JS, Fischer RS, Van Buren CB. Fatal Occupational Injuries. JAMA 1982; 248: 692-697.

11. Baumecker IC. Acidentes do trabalho: revendo conceitos e preconceitos com o apoio da ergonomia. Belo Horizonte; 2000a. [Dissertação de Mestrado Engenharia de Produção, Universidade Federal de Minas Gerais]. (p. 25-40).

12. Baumecker IC. Acidentes do trabalho: revendo conceitos e preconceitos com o apoio da ergonomia. Belo Horizonte; 2000b. [Dissertação de Mestrado Engenharia de Produção, Universidade Federal de Minas Gerais]. (p. 70-79).

13. Benner Jr L. Rating accidents models and investigation methodologies. In Hendrick K, Benner L. Investigation accidents with STEP. New York: Marcel Dekker Inc; 1986. p. 403-434.

14. Binder MCP. O Uso do método de árvore de causas na investigação de acidentes do trabalho típicos. Revista Brasileira de Saúde Ocupacional 1997; 23 (87/88): 69-92.

15. Binder MCP, Almeida IM. Indicações do método ADC. In Binder MCP, Almeida IM, Monteau M. Árvore de causas. Método de investigação de acidentes de trabalho. São Paulo: Publisher Brasil Editora; 1995. p. 71-85.

16. Binder MCP, Almeida IM. Estudo de caso de dois acidentes do trabalho investigados com o método de árvore de causas. Cadernos de Saúde Pública 1997a; 13: 749-760.

17. Binder MCP, Almeida IM. Anulando armadilhas. Proteção 1997b; 61: 40-45.

18. Binder MCP, Almeida IM. Gli infortuni sul lavoro in Brasile. Studio nello stato di S. Paolo del Brasile, regione di Botucatu, utilizzando il metodo dell'albero delle cause. Medicina del Lavoro 1999; 90: 584-595.

19. Binder MCP, Almeida IM, Azevedo ND. A construção da culpa. Trabalho \& Saúde 1994; 14 (37): 15-17. 
20. Binder MCP, Almeida IM, Monteau M. Árvore de causas. Método de investigação de acidentes de trabalho. São Paulo: Publisher Brasil Editora; 1995.

21. Binder MCP, Almeida IM, Monteau M. Analyse anthropotechnologique des accidents du travail. Bulletin of the World Health Organization 1999; 77: 1008-1016.

22. Binder MCP, Azevedo ND, Almeida IM. Análise crítica de investigações de acidentes do trabalho típicos realizadas por 3 empresas metalúrgicas de grande porte do Estado de São Paulo. Revista Brasileira de Saúde Ocupacional 1997; (85/86): 103 - 118.

23. Binder MCP, Pham D, Almeida IM. Diagnostic de Sécurité d'une entreprise brésilienne à partir de l'étude des accidents du travail avec la Méthode de l'arbre des causes. Cahiers Santé 1998; 8: 227 - 233.

24. Booth R. Accident prevention. In McDonald JC. Recent Advances in Occupational Health. London: Churchill Livingstone; 1981. p. 163 - 171.

25. Bourgeois F, Lemarchand C, Hubault F, Brun C, Polin A, Faucheux JM. Troubles musculosquelettiques et travail. Quand la santé interroge l'organisation. Paris: Anact; 2000.

26. Burgoyne JH. Reflections on accident investigation. Safety Science 1993; 16: 401-406.

27. Brandimiller PA. Perícia judicial em acidentes e doenças do trabalho. São Paulo: Editora SENAC; 1996.

28. Brasil / Ministério do Trabalho - Fundacentro. Manual de prevenção de acidentes para o trabalhador têxtil. São Paulo: Fundacentro; 1980. 
29. Brasil / Ministério do Trabalho - Fundacentro. Manual de Prevenção de Acidentes para Agentes de Mestria na Indústria Têxtil. São Paulo: Fundacentro; 1981.

30. Brasil / Ministério do Trabalho - Fundacentro. CIPA. Curso de treinamento. 2a. edição. São Paulo: Fundacentro; 1983.

31. Brasil / Ministério do Trabalho / Secretaria de Segurança e Saúde no Trabalho. Portaria № 968, de 9 de agosto de 1994. Diário Oficial da União, Brasília, 11 ago 1994. Seção 1, p.12.113.

32. Brasil / Ministério do Trabalho / Secretaria de Segurança e Saúde no Trabalho. Portaria No 1351, de 28 de dezembro de 1994. Diário Oficial da União, Brasília, 2 jan 1995, p. $49-52$.

33. Brasil / Ministério do Trabalho e Emprego. Legislação de Segurança e Medicina do Trabalho. São Paulo: Editora Atlas; 1998.

34. Brasil / Ministério do Trabalho e Emprego / Departamento de Segurança e Saúde no Trabalho. Manual da Cipa. A nova NR 5. Brasília: Departamento de Segurança e Saúde no Trabalho - DSST; 1999.

35. Brewer MB. An information-processing approach to attribution of responsibility. Journal of Experimental Social Psychology 1977; 13: 58-69.

36. Brown ID. Accident reporting and analysis. In Wilson JR, Corlett EN, editors. Evaluation of human work. A practical ergonomics methodology. London: Taylor \& Francis; 1990. p.755-778.

37. Camargo DA de A Influência dos Fatores Psicológicos nos Acidentes do Trabalho. São Paulo; 1988. [Hospital do SEPACO. Serviço Social da Indústria do Papel, Papelão e Cortiça do Estado de São Paulo, p. 162-173].

38. Carmo JC do, Almeida IM, Binder MCP, Settimi, MM. Acidentes do trabalho. In Mendes R Patologia do trabalho. São Paulo: Ed Atheneu; 1995. p. 431-455. 
39. Canadian Center for Occupational Health and Safety. A Guide to Accident investigation. 1998. Available from: < URL: http://www.ccohs.ca/oshanswers/ hsprograms/investig.html.>(2000 Jun 15).

40. Carpentier-Roy M-C, Ouellet F, Simard M, Marchand A. L'appui des travailleurs aux comités paritaires de santé et sécurité du Travail (CPSST): une analyse psychodinamique. Le Travail Humain 1998; 61: 171-185.

41. Carter FA, Corlett EN. Shiftwork and accidents. In Wedderburn A, Smith P. editors Psychological approaches to night and shiftwork. Edinburgh, Scotland: Heriot-Watt University; 1984. [International Research Papers].

42. Carvalho HV de, Segre M. Medicina Social e do Trabalho. São Paulo: Editora McGraw-Hill do Brasil Ltda; 1977. Doutrina do risco profissional e conceito de acidente do trabalho; p. 249-297.

43. Chich Y, Chartier M, De Keyser V, Malaterre G, Monteau M. L'apport de l'analyse pluridisciplinaire des accidents a l'action de prévention. Le Travail Humain 1984; 47 (3): 237-247.

44. Claire J. Occupational injury. Accidental or a reflection of conflict between capital and labour Australian and New Zeland Journal of Sociology 1987; 23: $47-62$.

45. Clemente D. Análise e Comunicação do Acidente do Trabalho. In Fundacentro Curso de Engenharia do Trabalho. Livro 6. São Paulo: Fundacentro; 1981. p. 1439-1454.

46. Cohn A, Karsh US, Hirano S, Sato AK. Acidentes do Trabalho. Uma Forma de Violência. São Paulo: Ed. Brasiliense / CEDEC; 1985.

47. Cooper D. Risk based safety culture in industry. Do you have one? 1999. Available from: < URL: http://www.behaviour-safety.com > (2000 Oct 27). 
48. Cuny X. Evaluation qualitative de l'application de l'arbre des causes en entreprise. In: Actes $5^{\text {èmes }}$ Journées de Médecine du Travail, Epidemiologie Ergonomie dans les Petites et Moyennes Entreprises, 1995 Amiens, France: 1995. p. 33-35.

49. Davillerd C. L'Affiche de prévention, de L'INS à L'INRS. L'evolution du message et de sa représentation à travers deux thèmes. Paris: INRS; 1998.

50. Dejours C. A inteligência operária e a organização do trabalho. A propósito do modelo japonês de produção. In Hirata $H$, organizador. Sobre o modelo japonês. São Paulo: Edusp; 1993a. p. 281-309.

51. Dejours C. Intelligence pratique et sagesse pratique: deux dimensions méconnues du travail réel. Revue Education Permanente 1993b; (116): 47-70. [primeira parte, terceiro trimestre].

52. Dejours C. A propos de: “Accidents industriels: le cout du silence”. Revue Internationale de Psychosociologie 1996; vol III (3): 161-168.

53. Dejours C. O fator Humano. São Paulo: Editora FGV; 1997.

54. Dejours C, Abdoucheli E. Itinerário teórico em psicopatologia do trabalho. In Dejours C, Abdoucheli E, Jayet C, coordenadora Betiol MIS. Psicodinâmica do trabalho. Contribuições da Escola Dejouriana à análise da relação prazer, sofrimento e trabalho. São Paulo: Atlas; 1994. p. 119-145.

55. Dejoy DM. Attributional Processes and Hazard Control Management in Industry. Journal of Safety Research 1985; 16: 61-71.

56. Dejoy DM. Theoretical models of health behavior and workplace self-protective behavior. Journal of Safety Research 1996; 27: 61-72.

57. De Keyser V. La Méthode INRS. Quelques réflexions sur son utilisation. Promosafe 1979; (Oct - Nov): 5 - 11. 
58. De Nève MB Le phénomène accident. Paris: INRS; 1975. [Rapport $n^{\circ}$ $511 / \mathrm{RE}]$.

59. Dodier N. Causes et mises en cause. Innovation sociotechnique et jugement moral face aux accidents du travail. Revue Française de Sociologie 1994; (XXXV): 251-281.

60. Doos M, Backstrom T, Samuelsson S. Evaluation of a strategy. Preventing accidents with automated machinery through targeted and comprehensive investigation conducted by safety engineers. Safety Science 1994; 17: 187-206.

61. Dumaine J. La modélisation du phénomène accident. Accidentologie et recherche a priori des risques graves. Securité et Medicine du Travail 1985 (71): 11-22.

62. Dwyer T. A produção social dos acidentes de trabalho. [Apresentado ao $1^{\circ}$ seminário Franco Brasileiro sobre "Emprego, Divisão de trabalho, Divisão de Riscos e Saúde" - USP, 1984, São Paulo].

63. Dwyer T. Life and death at work. Industrial accidents as a case of socially produced error. New York and London: Plenum Press; 1991.

64. Dwyer T. Os imperativos para o desenvolvimento de um novo paradigma de Saúde e Segurança no trabalho. A perspectiva de um país em desenvolvimento. [Apresentado ao XV Congresso Mundial sobre Segurança e Saúde no Trabalho; 1999 abr 12-20; São Paulo, Brasil. - mimeo].

65. Dwyer T; Raftery AE. Industrial accidents are produced by social relations of work: a sociological theory of industrial accidents. Applied Ergonomics 1991; 22:167-178.

66. Faverge JM. Psychosociologie des accidents du travail. Paris, Presses Universitaires de France, 1967. 
67. Favrot G, Milbergue G. Action preventive et formation. L'utilisation de l'arbre des causes. Sécurité et Médecine du Travail 1985; 71: 30 - 33.

68. Feggetter AJ. A method for investigating human factor aspects of aircraft accidents and incidents. Ergonomics 1982; 25: 1065-1075.

69. Ferrão GM. Colhendo resultados. Proteção 1996; 58: 44-46.

70. Ferreira ABH. Dicionário Aurélio Básico da Língua Portuguesa. São Paulo: Folha de São Paulo / Editora Nova Fronteira; 1995. Acidente. p. 10.

71. Feyer AM, Willianson AM. A classification system for causes of occupational accidents for use in preventive strategies. Scand. J. Work Environ. Health 1991; 17: 302-11.

72. François R, Gerey M, Hantz JM. Comment lutter contre les accidents du travail. Paris: Édition de l'Usine Nouvelle; 1985. La réglementation relative à la prévention. p. 41-58.

73. Freitag M, Hale A. Structure of event analysis In Hale A, Wilpert B, Freitag M After the event. From accident to organizational learning. Oxford, New York: Pergamon / Elsevier Science; 1997. p. 11-22.

74. Garcia EG. Segurança e saúde no trabalho rural com agrotóxicos. Contribuição para uma abordagem abrangente. São Paulo, 1996 [Dissertação de Mestrado - Faculdade de Saúde Pública da USP].

75. Gielen AC. Health education an injury control: integrating approaches. Health Education Quarterly 1992; (2): 203-218.

76. Goguelin P. La prévention des risques professionels. Paris: Presses Universitaires de France; 1996. [Que sais-je? No 3082].

77. Guérin F, Laville A, Daniellou F, Duraffourg J, Kerguelen A. Comprendre le travail pour le transformer. La pratique de l'Ergonomie. Lyon: Anact 1997. Des bases pour une pratique. p. 77-104. 
78. Haddon Jr W. The changing approach to the epidemiology, prevention, and amelioration of trauma: the transition to approaches etiologically rather than descriptively based. American Journal of Public Health 1968 (8): 1431-38.

79. Haddon Jr W. Advances in the Epidemiology of injuries as a Basis for Public Policy. Public Health Reports 1980 (5): 411-421.

80. Haddon Jr W, Baker SP. Injury control. In Clark DW, MacMahon B Preventive and Community Medicine. Boston: Little, Brown and Company; 1981. p. 109-140.

81. Hale AR. Methodological and organisational issues. Safety Science 1993; 16: 397-399. [Editorial].

82. Hale AR, Glendon AI. Individual behaviour in the control of danger. Amsterdam: Elesevier; 1987a. Individual behaviour and control of danger p. 123.

83. Hale AR, Glendon AI. Individual behaviour in the control of danger. Amsterdam: Elesevier; 1987b. Models of behaviour in the face of danger p. 2745.

84. Hale AR, Glendon AI. Individual behaviour in the control of danger. Amsterdam: Elesevier; 1987c. Danger in routine tasks p. 47-71;

85. Hale AR, Glendon AI. Individual behaviour in the control of danger. Amsterdam: Elesevier; 1987d. Safety and responsibility p. 161-190.

86. Hale AR, Glendon AI. Individual behaviour in the control of danger. Amsterdam: Elesevier; 1987e.

87. Hale AR, Hale M. A review of the industrial accident research literature. London: Her Majesty's Stationery Office; 1972 [Committee on Safety and Health at Work Research Papper]. 
88. Hale A, Wilpert B, Freitag M. After the event. From accident to organizational learning. Oxford, New York: Pergamon / Elsevier Science; 1997.

89. Hallgren L-E. The prevention of occupational accidents in industry. In Menckel E, Kullinger B (Ed) Fifteen years of occupational - accident research in Sweden. Stockholm: Swedish Council for Work Life Research; 1996. p. 111-119.

90. Harms-Ringdahl L. From accidents to integrated safety management. In Menckel E, Kullinger B (Ed) Fifteen years of occupational - accident research in Sweden. Stockholm, Swedish Council for Work Life Research, 1996. p. 102-110.

91. Heinrich HW. Industrial Accident Prevention. A Scientific Approach. New York: McGraw-Hill Book Company, Inc; 1959.

92. Hirano S, Redko CP, Ferraz VRT. A cidadania do trabalhador acidentado: (Re)conhecimento do direito aos direitos sociais. Tempo Social: Revista de Sociologia da USP 1990; 2: 127-150.

93. Ho MT, Bastide J-C, François C. Mise au point d'un système destiné a l'exploitation de comptes rendus d'analyse d'accidents du travail. Le Travail Humain 1986; 49: 137-146.

94. Hofman DA, Jacobs R, Landy F. High reliability process Industries: individual, micro, and macro organisational influences on safety performance. Journal of Safety Research 1995; 26: 131-149.

95. Hoyos CG, Zimolong B. Occupational safety and accident prevention: behavioral strategies and methods. Amsterdam: Elsevier; 1988. [Advances in Human Factors / Ergonomics, 11].

96. Institut National de Recherche et Sécurité. Enseigner la prévention des risques professionsels. L'Arbre des causes. Paris: INRS; 1993. 
97. Janoff-Bulman R. Esteem and control bases of blame: "Adaptative" strategies for victims versus observers. Journal of Personality 1982; 50: 181-192.

98. Johnson WG. Sequences in accident causation. Journal of Safety Research 1973; 5: 54-57.

99. Johnson WG. MORT: The management oversight and risk tree. Journal of Safety Research 1975; 7: 4-15.

100. Karuza J Jr, Carey TO. Relative preferences and adaptiveness of behavioral blame for observers os rape victims. Journal of Personality 1984; 52: 240-260.

101. Kirwan B. Human Error. Identification in Human Reliability Assessment. Part 1: Overview of approaches. Applied Ergonomics 1992; 23: 299-318.

102. Kirwan B. Human Error. Identification in Human Reliability Assessment. Part 2: Detailed comparispn of techniques. Applied Ergonomics 1992; 23: 371381.

103. Kletz T. Accident data - the need for a new look at the sort of data that are collected and analysed. Safety Science 1993; 16: 407-415.

104. Kletz T. O que houve de errado? Rio de Janeiro, Makron Books, 1993.

105. Konder L. A derrota da dialética. Rio de Janeiro: Editora Campus; 1988. Ímpeto rebelde e projeto revolucionário. p. 19-49.

106. Kouabenan DR. L'Analyse des attribuitions causales des accidents. Le Travail Humain 1985; 48: 1-17.

107. Kouabenan DR. Beliefs and the perception of risks and accidents. Risk Analysis 1998; 18: 243-252.

108. Kouabenan DR. Explication naïve de l'accident et prévention. Paris: Presses Universitaires de France; 1999a. La notion de cause dans l'explication naïve: des distinctions utiles. p. 15-45. [PUF - Collection Le Travail Humain]. 
109. Kouabenan DR. Explication naïve de l'accident et prévention. Paris: Presses Universitaires de France; 1999b. L’Expertise en sécurité. p. 195-212. [PUF - Collection Le Travail Humain].

110. Kouabenan DR. Explication naïve de l'accident et prévention. Paris: Presses Universitaires de France; 1999c. La prévention des accidents. p. 213-237. [PUF - Collection Le Travail Humain].

111. Kouabenan DR. Explication naïve de l'accident et prévention. Paris: Presses Universitaires de France; 1999d. Conclusion. p. 239-241. [PUF Collection Le Travail Humain].

112. Langley JD. The need to discontinue the use of the term "accident" when referring to unintentional injury events. Accident Analysis \& Prevention 1988; 20: $1-8$.

113. Lara Duca AC. Estudo de causas de acidentes pelo método INRS. In Anais do V Congresso da ANAMT; 1987 abr/mai 27 - 1º, Florianópolis, Santa Catarina, Brasil. Associação Nacional de Medicina do Trabalho, 1987. p. 823 832.

114. Ledeme D. Face a un accident. Que faire? Paris: IN. PACT, 1995.

115. Leplat J. L'accident une fatalité? Cahier de la Mutualité dans l'Entreprise, Santé et Conditions de Travail 1983; 5: 7-27.

116. Leplat J. Erreur humaine, fiabilité humaine dans le travail. Paris: Armand Colin; 1985.

117. Leplat J. Event analysis and responsibility in complex systems. In Hale A, Wilpert B, Freitag M. After the event. From accident to organizational learning. Oxford, New York: Pergamon / Elsevier Science; 1997. p. 23-40.

118. Leplat J, Cuny X. Les accidents du travail. Paris: PUF; 1979. 
119. Leplat J, Rasmussen J. Analysis of human errors in industrial incidents and accidents for improvement of work safety. In Rasmussen J, Duncan K, Leplat J. New Technology and human error. Chichester: John Wiley \& Sons; 1987. p. $157-168$.

120. Levanthal H, Singer R, Jones S. Effects of fear and specificity of recommendation upon attitudes and behavior. Journal of Personality and Social Psychology 1965; 2: 20-29.

121. Lieber RR. Teoria e metateoria na investigação da causalidade. $O$ caso do acidente do trabalho. São Paulo; 1998. [Tese de Doutoramento - Faculdade de Saúde Pública da USP].

122. Lima A. Culpa e risco. $2^{\text {a }}$ ed. São Paulo: Editora Revista dos Tribunais; 1998a. Introdução; p. 13-42.

123. Lima A. Culpa e risco. $2^{\mathrm{a}}$ ed. São Paulo: Editora Revista dos Tribunais; 1998b. Da responsabilidade extracontratual sob o fundamento da culpa; p. 43111.

124. Lima A. Culpa e risco. $2^{\text {a }}$ ed. São Paulo: Editora Revista dos Tribunais; 1998c. Da responsabilidade extracontratual sem culpa; p. 113-202.

125. Lima A. Culpa e risco. $2^{\mathrm{a}}$ ed. São Paulo: Editora Revista dos Tribunais; 1998d. Situação atual no Direito Civil Moderno, das teorias da culpa e do risco; p. 327-336.

126. Lima FPA, Assunção AA. Análise dos acidentes: Cia de Aços Especiais Itabira. Belo Horizonte; Laboratório de Ergonomia DEP/UFMG, 2000.

127. Llory M. Accidents industriels. Opérateurs privés de parole et cadres introuvables. Paris: L’Harmattan; 1996. (Há edição brasileira: Acidentes industriais: o custo do silêncio. Rio de Janeiro: Multimais Editorial; 1999.). 
128. Magrini R de O, Ferreira CSW. Análise de Acidentes: Busca de um culpado? São Paulo, s/d [mimeo].

129. Magrini R de O, Martarello NA. Condições de trabalho na operação de prensas. In Costa DF; Carmo J do C, Settimi MM, Santos U de P. Programa de saúde dos trabalhadores. A experiência da Zona Norte: uma alternativa em Saúde Pública. São Paulo: Hucitec; 1989. p. 267-297.

130. McCullough W. Ambiente de Trabalho. Segurança, Higiene, Produtividade. Rio de Janeiro: Forum Editora Ltda; 1973.

131. McKenna SP, Glendon AI. First aid training: can it help prevent accidents? Safety Surveyor 1980; 8: 22-28.

132. McKenna SP, Hale AR. Changing behaviour towards danger: The effect of first aid training. Journal of Occupational Accidents 1982; 4: 47-59.

133. McKenna FP, Stanier RA, Lewis C. Factors underlying illusory selfassessment of driving skill in males and females. Accident Analysis and Prevention 1991; 23: 45-52.

134. Menckel E, Kullinger B, editores. Fifteen years of occupational - accident research in Sweden. Stockholm: Swedish Council for Work Life Research; 1996.

135. Mendel G. Preface. In Llory M. Accidents industriels. Opérateurs privés de parole et cadres introuvables. Paris: L'Harmattan; 1996. p: 9 - 21.

136. Méric M. Enseignements tirés de formation en entreprises a l'Arbre des causes d'un accident: De la transmission d'une technique à la formation action. [Communication présentée au IIIème Congrès Psychologie du Travail de Langue Française. 1984 20-23 Fevrier, Paris, France].

137. Méric M, Szekely J. Diagnostic de la Sécurité Préalable a la definition d'Actions de la Prevention. Étude pilote réalisée dans une fabrique de 
panneaux d'agloméré. Nancy, France: Institut National de Recherche et de Sécurité - INRS; 1980. [Rapport no 399 / RE].

138. Méric M, Monteau M, Szekely J. Techniques de gestion de la Sécurité. Paris: Institut National de Recherche et de Sécurité - INRS; 1976. [Rapport $n^{\circ}$ 243 / RE].

139. Mielnik, I. Higiene Mental do Trabalho. São Paulo: Artes Médicas; 1976.

140. Monteau M. Méthode Pratique de recherche de facteurs d'accidents. Principles et application expérimentale. Vandoeuvre, França: INRS; 1974. [Rapport no 140 / RE].

141. Monteau M. Bilan des Méthodes D'Analyse D'Accidents du Travail. Nancy: France; 1979. [Rapport nº 456 / RE, INRS].

142. Monteau M. La gestion de la sécurité du travail dans l'entreprise: du carter au plan qualité. Performances Humaines \& Techniques, 1992 (nº 61): 29-34.

143. Monteau M. La sécurité en entreprise: facteurs et evolution. Vandoeuvre: Institut National de Récherche et de Sécurité INRS; s/d. [Mimeo].

144. Monteau M. Analysis and reporting: accident investigation. In International Labour Office Encyclopaedia of Occupational Health and Safety. [CD Rom]. Ginebra: International Labour Office; 1999. (Chapter: Audits, inpections and investigations. Vol 2 - 57.1-57.31).

145. Monteau M, Favaro M. Bilan des Méthodes d'analyse a priori des risques. 1. Des contrôles à l'ergonomie de systémes. Cahiers de Notes Documentaires, 1990 (nº 138): 91-114.

146. Monteau M, Pham D. L'Accident du Travail - Evolution des conceptions. In Levy-Leboyer C, Sperandio JC. Traité de Psychologie du Travail. Paris: P.U.F.; 1988. [Reproduzido por INRS, França, s/d]. 
147. Nichols T. The sociology of accidents and the social production of industrial injury. In Esland G e col, editors. People and work. Edinburg: Holmes McDougal and Open University Press; 1975. p. 217-229.

148. Nolter JC, Johnson RD. How to conduct an accident investigation. In Lawrence S Handbook of Occupational Safety and Health. New York: Wiley-Interscience Publications. John Wiley \& Sons, 1987.

149. Oliveira F. A Construção Social dos Discursos sobre o Acidente de Trabalho. São Paulo;1997. [Dissertação de Mestrado - Instituto de Psicologia da USP].

150. Oliveira JC. Fundamentos básicos de Gerenciamento da Segurança e Saúde do Trabalhador. Belo Horizonte, 2000. [Apostila do Curso "Gestão de riscos no trabalho: princípios e práticas aplicáveis à Auditoria Fiscal do Trabalho" Ministério do Trabalho e Emprego].

151. Oushiro OM. Manual de Prevenção de Acidentes para o Trabalho e Têxtil. São Paulo: Fundacentro; 1980.

152. Paixão F. A previdência Social em perguntas e respostas. $23^{\mathrm{a}}$ ed. Porto Alegre: Editora Síntese Ltda. 1991. Lei 8213; p: 167-233.

153. Paté-Cornell ME. Learning from Piper Alpha Accident: a postmortem analysis of technical and organizational factors. Risk Analysis 1993; 13: 215232.

154. Perrow C. Normal Accidents. New Jersey: Princeton University Press; 1999. Complexity, coupling, and catastrophe; p: 62-100.

155. Perrow C. Normal Accidents. New Jersey: Princeton University Press; 1999. Afterword; p: 353 - 387.

156. Pham D. Quelques facteurs de réussite ou échec de l'introduction dans l'entreprise de la méthode "arbre des causes" de l'INRS. Etude comparative dans 
deux établissements d'un groupe industriel. Cahiers de Notes Documentaires 1989; (nº 135): 347-354.

157. Pham D, Monteau M. L'Arbre des causes: mieux connaître les risques pour mieux les combattre. Le Journal des Psychologues, 1989 (nº 72): 42-44.

158. Rasmussen J, Duncan K, Leplat J. New Technology and human error. Chichester: John Wiley \& Sons; 1987.

159. Reason J. Human error. Cambridge: Cambridge University Press; 1999.

160. Ribeiro Filho LF. Acidente do trabalho. In Ministério do Trabalho / Fundacentro. Curso de Medicina do Trabalho. Livro 3. São Paulo, Fundacentro, 1981. p. 765-791.

161. Rogers RW, Mewborn CR. Fear appeals and attitude change: effects of a threat's noxiousness, probability of ocurrence, and the Efficacy of Coping Responses. Journal of Personality and Social Psychology 1976; 34: 54-61.

162. Rouhiainen V. Inadvertent starts causing accidents. Journal of Occupational Accidents 1982; 4: 165-170.

163. Saad EG, organizador. Introdução a Engenharia de Segurança do Trabalho. São Paulo: Fundacentro; 1981.

164. Saas R, Cook G. Accident proneness: science or non-science? International Journal of Health Services 1981; 11:175-190.

165. Serviço Social da Indústria. Departamento Regional de São Paulo. Evite Acidentes. CIPA Jornal 1967; ANO XVIII (141): 2-3.

166. Simard M. La Prise de Risque Dans le Travail, un Phénomene Organisationnel. In Goguelin P, Cuny X La Prise de Risque Dans le Travail. Paris: Octares Edition; 1989. p. 71-85. 
167. Simard M, Marchand A. The behaviour of first line supervisors in accident prevention and effectiveness in occupational safety. Safety Science 1994; 17: $169-185$.

168. Sindicato dos Químicos SP / Sindicato dos Plásticos SP. Construindo a árvore de causas. São Paulo: Sindicato dos Trabalhadores nas Indústrias Químicas e Farmacêuticas de São Paulo / Sindicato dos Trabalhadores nas Indústrias de Material Plástico e nas Indústrias da Produção de Laminados Plásticos de São Paulo; 1993.

169. SNCF. L'arbre des causes. Mieux comprendre un événement. Paris: SNCF; s/d.

170. Sperandio JC. Les processus cognitifs au cours du travail. In Cazamian P, Hubault F, Noulin M. Traité d'Ergonomie. Nouvelle édition actualisée. Toulouse: Octares Édition; 1996. p. 181-190.

171. Sulzer-Azaroff B. Behavioral Approaches to Occupational Safety and Health. In Frederiksen L Handbook of organisational Behavior Management. New York: John Wiley \& Sons; 1982. p. 505-538.

172. Sulzer-Azaroff B. The modification of Occupational Safety Behavior. Journal of Occupational Accidents 1987; 9: 177-197.

173. Surry J. Industrial accident research. A human engineering appraisal. Toronto, Labour Safety Council. Ontario Department of Labour, 1971.

174. Szasz A. Accident proneness. The career of an ideological concept. Psychology \& Social Theory 1984; 4: 24-35.

175. Teiger C. Représentation du travail et travail de la représentation In WeilFassina A, Rabardel P, Dubois, D Représentations pour l'action Toulouse; Octares Éditions, 1993. p 311-344. 
176. Tversky A, Kahneman D. Judgement under uncertainty: heuristics and biases. Science 1974; 185: 1124-1131.

177. Wagenaar WA, Reason JT. Types and tokens in road accident causation. Ergonomics 1990; 33 (10/11): 1365-1375.

178. Waller JÁ. Injury conceptual shifts and preventive implications. Annual Review of Public Health 1987; 8: 21-49.

179. Webb GR, Redman S, Wilkinson C, Sanson-Fisher RW. Filtering effects in reporting work injuries. Accident Analysis \& Prevention 1989; 21: 115-123.

180. Weill-Fassina A. Dynamique des représentations et gestions des actions In Weil-Fassina A, Rabardel P, Dubois, D. Représentations pour l'action Toulouse; Octares Éditions, 1993. p 237-245.

181. Wigglesworth EC. A teaching model of injury causation and a guide for selecting countermeasures. Occupational Psychology,1972; 46: 69-78.

182. Wigglesworth EC. Occupational Injuries: An Exploratory Analysis of Successful Australian Strategies. Med. J. Austral. 1976; 1: 335- 339.

183. Wigglesworth EC. The Fault Doctrine and Injury Control. The Journal of Trauma 1978; 18: 789-794.

184. Wilpert B. After the event: what next? In Hale A, Wilpert B, Freitag M. After the event. From accident to organizational learning. Oxford, New York: Pergamon / Elsevier Science; 1997. p. 233-244.

185. Wisner A. Vers une anthropotecnologie. Comment pourvoir les pays en voie de développement de machines et d'usines qui marchent. Paris: CNAM; 1983.

186. Wogalter MS, Young SL, Brelsford JW, Barlow T. The relative contributions of injury severity and likelihood on hazard-risk judgments and Warning compliance. Journal of Safety Research 1999; 30: 151-162. 
187. Zocchio A. Prática da prevenção de acidentes. ABC da segurança do trabalho. São Paulo: ATLAS; 1980. 